TRANSMISSAO DE PRECYOS DE CARNE BOVINA ENTRE NIVEIS DE MERCADO: UMA APLICACAO DO MODELO DE AUTO-REGRESSAO VETORIAL

\author{
FLĀVIA MARIA DE MELLO BLISKA \\ Engenheiro Agrônomo
}

Orientador: Prof. Dr. GERALDO SANT'ANA DE CAMARGO BARROS

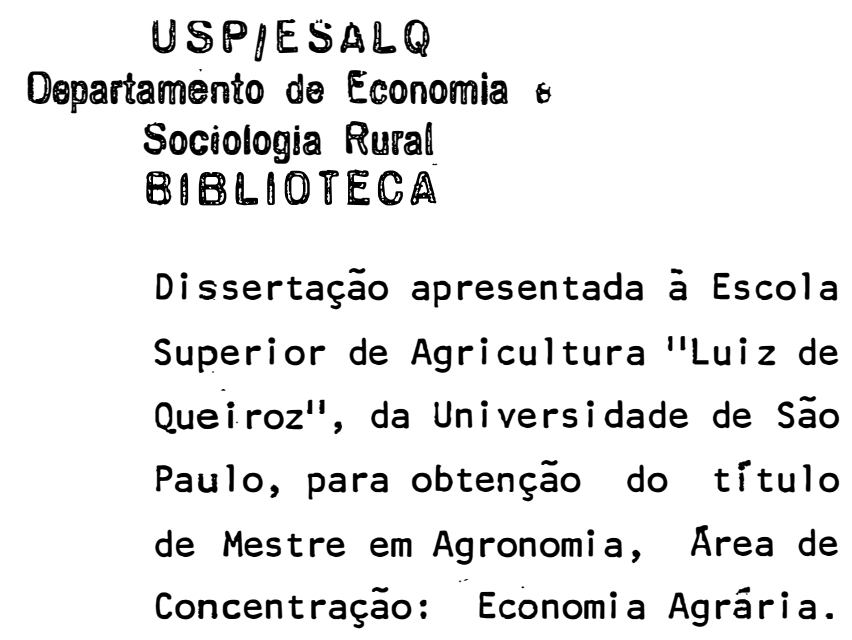


Ficha catalográfica preparada pela Seção de Livros da Divisão de Biblioteca e Documentação - PCAP/USP

Bliska, Flávia Maria de Mello

B431t Transmissão de preços de carne bovina entre ní veis de mercado; uma aplicação do modelo de autoregressão vetorial. Piracicaba, 1989.

209p. ilus.

Diss.(Mestre) - ESALQ

Bibliografia.

1. Carne bovina - Comercialização 2. Carne bovi na - Mercado - Modelo econométrico 3. Carne bovina Preço I. Escola Superior de Agricultura Luiz de Quei roz, Piracicaba

CDD 338.1762 


\section{TRANSMISSÃO DE PREÇOS DE CARNE BOVINA ENTRE NÍVEIS \\ DE MERCADO: UMA APLICACÃO DO MERCADO DE \\ AUTO-REGRESSÃO VETORIAL}

FLÁvia MARIA DE MELLO BLISKA

Aprovada em: 23.11 .1989

Comissāo julgadora:

Prof. Dr. Pedro Valent im Marques .:

ESALQ/USP

Prof. Dr. Joaquim José Martins Guillhoto.......

ESALQ/USF

Dr. Flávio Condé de Carvalho

IEA

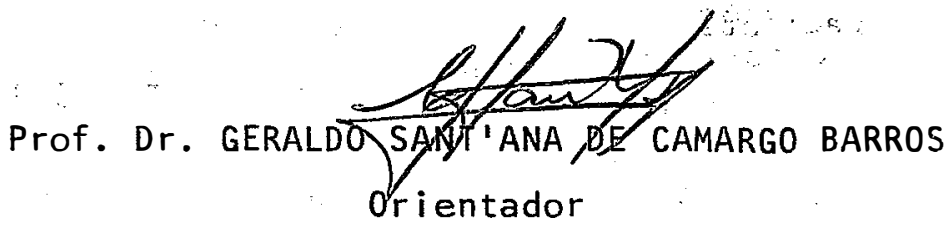


A autora agradece, em especial, a:

Prof. Dr. GERALDO SANT'ANA DE CAMARGO BARROS, orientação, críticas e sugestões;

Proj. Dr. PEDRO VALENTIM MARQUES, críticas e sugestões;

Prof. Dr. JOARUTM JOSE MARTINS GUTLHOTO, críticas e sugestões;

Dr. FLAUIO CONDE DE CARVALHO, pesquisador cientifico do Instituto de Economia Agrícola, críticas e sugestões;

LUIZ MORICOSHI, pesquisador científico do Instituto de Economia Agrícola, incentivo e colaboração no desenvolvimento de todo o trabalho;

ANTONIO LUDOVICO BERALDO, engenhei ro agrícola e matemätico, professor da Universidade Estadual de Campinas, orientação na ärea de informätica e empréstimo de microcomputador, indispensāvel na realização desta dissertação;

NORMA DOS SANTOS DE MELLO, minha mãe, incentivo e apoio constantes, durante todo o curso de pós-graduação, que muito auxiliaram no desemvolvimento deste trabalho;

ANTONIO BLISKA Jr., meu marido, incentivo, paciência, apoio e carinino constantes;

INES DUARTE DOS SANTOS, dati lografia;

THEREZINHA PRESTA MANETTI, datilografia; 
IRENE FRANCISCA LUCATTO, fotocópias;

COORDENAÇÃO DE APERFEIÇOAMENTO DE PESSOAL DE NIUVEL SUPERIOR (CAPES), bolsa de estudos durante o curso de pós-graduação;

FUNDAÇAO DE AMPARO A PESQUTSA DO ESTADO DE SÃO PAULO (FAPESP), bolsa de estudos para desenvolvimento do projeto de dissertação; INSTITUTO DE ECONOMIA AGRICOLA, recursos materiais. 
Para:

Fabiana,

Alexandre $e$

Adriano 
Pägina

LISTA DE FIGURAS ...................... vii

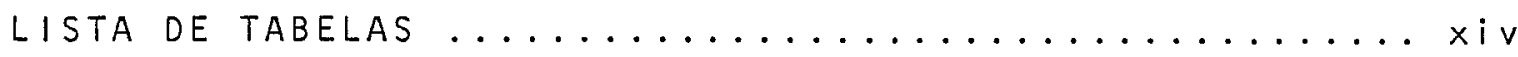

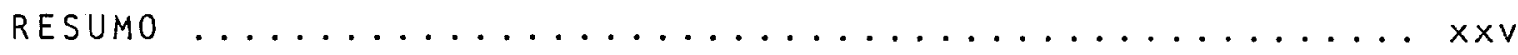

SUMMARY $\ldots \ldots \ldots \ldots \ldots \ldots \ldots \ldots \ldots \ldots \ldots \ldots \ldots \ldots \ldots \ldots \ldots \ldots$

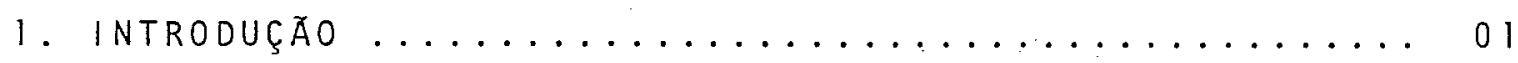

1.1. Importāncia do Problema .................. 01

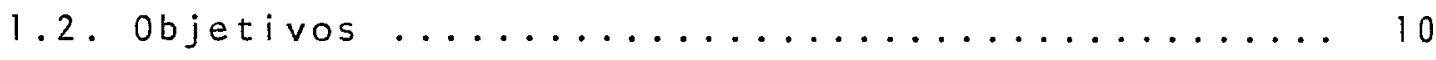

1.3. Revisão de Literatura .................. 10

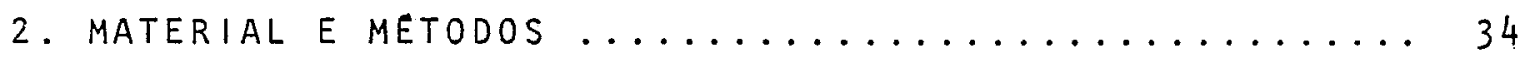

2.1. Dados Bàsicos ................... 34

2.1.1. Preços a nível de produtor ......... 35

2.1.2. Preços a nível de atacado ...........40

2.1.3. Preços a nível de varejo...........4 41

2.2. Aspectos Teóricos e Modelo Econömico ......... 44

2.3. Processos Auto-Regressivos Vetoriais

e Causalidade ........................ 50

2.3.1. Processos Auto-Regressivos Vetoriais ... 51

2.3.2. Teste da Razão de Verossimilhança..... 56

2.3.3. Simulação de respostas a choques aleatórios ....................... 58

2.3.4. Decomposição da variância dos erros de previsão de K-períodos 
Página

2.4. Anälise de Causalidade .................63

2.5. Anälise Harmônica ...................... 71

2.6. Margens de Comercialização ............. 73

3. RESULTADOS E DISCUSSÃO .......................... 79

3.1. Nümero de Defasagens Incluidas no Modelo ..... 79

3.2. Anālise de Causalidade ................ 80

3.3. Mecanismos de Propagação de Choques ......... 86

3.4. Anälise de Decomposição da Variància dos

Erros de Previsão ...................... 95

3.5. Anālise das Margens de Comercialização ....... 99

3.5.1. Parcelas de comercialização

Interanuais ..................... 101

3.5.2. Parcelas de comercialização

intra-anuais .................. 117

3.5.3. Margens de comercializaçäo em 1971 ,

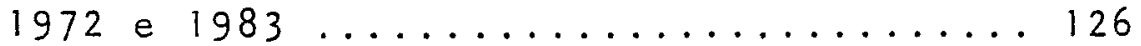

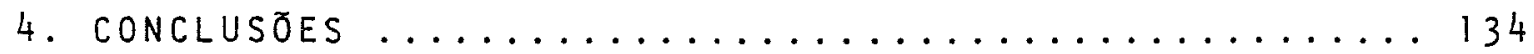

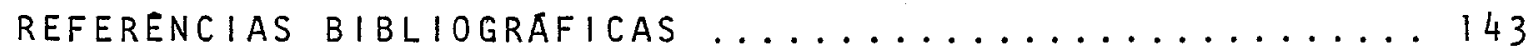

APENDICE 1: Tabelas de preços correntes utilizados ... 152

APENDICE 2: Efeitos de choques e decomposição da

variância dos erros de previsão ........ 167

APENDICE 3: Parcelas absolutas de comercialização .... 191 
Variação estacional dos preços recebidos pelos produtores de boi gordo, Estado de

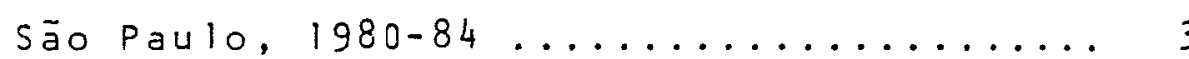

Estado de São Paulo: evolução dos preços reais recebidos pelos produtores de boi

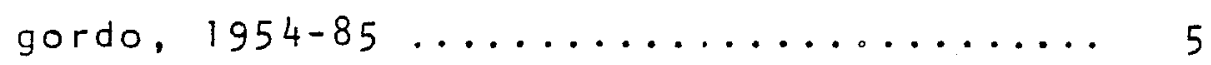

Conversões físicas e rendimentos industriais médios para a carne bovina ....... 26 Estrutura utilizada no cälculo das margens de comercialização de carne bovina..

Fluxograma de comercializaçäo da carne bovina na cidade de são Paulo ........... 36 Gräfico de $A \operatorname{sen}\left(\lambda_{t}+\dot{\phi}\right) \ldots \ldots \ldots \ldots \ldots \ldots \ldots \ldots$ Comportamento de preços e margens ...... 74 Subprodutos para cálculo de margens de comercialização de carne bovina e respectivos rendimentos ............... 78

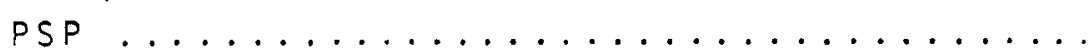


10 Respostas a um choque de uma unidade em V.... 91

11 Respostas a um choque de uma unidade em A... 92

12 Parcela porcentual de comercialização de carne bovina. Médias anuais, $(1971 / 87) \ldots 102$

13 Parcela porcentual do varejo. Médias

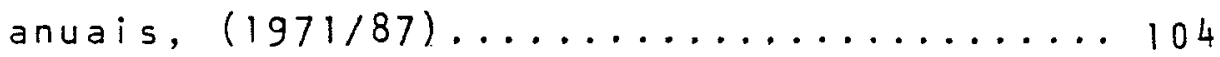

Parcela porcentual do atacado. Médias

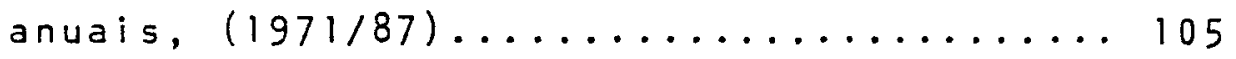

15 Parcela porcentual do produtor. Médias anuais, $(1971 / 87) \ldots \ldots \ldots \ldots \ldots \ldots$

16 Parcelas porcentuais de comercialização de carne bovina. Mëdias anuais, (1971/87).. 108

17 Preços médios anuais reais recebidos pelos produtores paulistas e mercados varejista e atacadista da cidade de São Paulo, em $\mathrm{czs} / \mathrm{kg},(1971 / 87) \ldots \ldots \ldots \ldots \ldots \ldots \ldots$

18 Parcelas porcentuais de comercialização de carne bovina de segunda, nos açougues e supermercados da cidade de São Paulo. Médias anuais, $(1.971 / 87) \ldots \ldots \ldots \ldots \ldots \ldots$ 
Parcelas porcentuais de comercialização de carne bovina de primeira, nos açougues e supermercados da cidade de são paulo. Mễi as anuais, $(1971 / 87) \ldots \ldots \ldots \ldots \ldots \ldots \ldots \ldots$ Parcelas porcentuais de comercialização de carne bovina (média ponderada entre carne de primeira e de segundal dos açougues e supermercados da cidade de são Paulo. Médias anuais $(1971 / 87) \ldots \ldots \ldots \ldots 112$ Parcela porcentual total de comercialização de carne bovina. Mëdias mensais, $(1971 / 87)$

Parcela porcentual do produtor. Mëdias mensais, $(1971 / 87) \ldots \ldots \ldots \ldots \ldots \ldots \ldots$ Parcela porcentual do atacado. Médias mensais, $(1971 / 87) \ldots \ldots \ldots \ldots \ldots$ Parcela porcentual do varejo. Médias mensais, $(1971 / 87) \ldots \ldots \ldots \ldots \ldots \ldots \ldots$

25 Parcelas porcentuais de comercialização de carne dovina. Médias mensais, 1971/87... 120 
Parcelas porcentuais de comercialização de carne bovina de segunda, dos açougues e supermercados da cidade de são paulo. Mëdias mensais, $1971 / 87 \ldots \ldots \ldots \ldots \ldots \ldots \ldots$

27 Parcelas porcentuais de comercialização de carne bovina de primeira dos açougues e supermercados da cidade de são Paulo. Mëdias mensais, $1971 / 87 \ldots \ldots \ldots \ldots \ldots \ldots \ldots \ldots$

28 Parcelas porcentuais de comercialização de carne bovina (mēdia ponderada entre carne de primeira e de segunda) dos açougues e supermercados da cidade de são Paulo. Médias mensais, $1971 / 87 \ldots \ldots \ldots$ i 22

29. Margens porcentuais de comercialização de carne bovina do atacado e do varejo e parcela porcentual, 1971............126

30 Margens porcentuais de comercialização de carne bovina do atacado e do varejo e parcela porcentual do produtor, $1972 \ldots \ldots \ldots 127$

Margens porcentuais de comercialização de

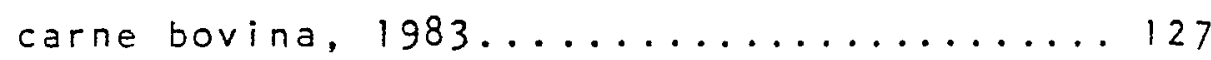


Margem porcentual total de comercialização de carne bovina, 1971...........132

Margem porcentual total de comercialização de carne bovina, 1972............132

Margem porcentual total de comercialização de carne bovina, 1983............133

Parcelas absolutas de comercialização de carne bovina, em $C z \$ / k g$. Médias anuais,

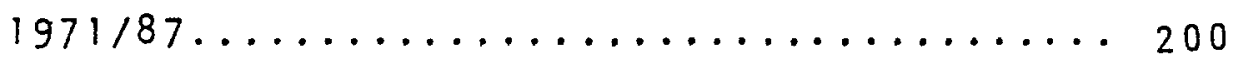

Parcela absoluta total de comercialização - de carne bovina, em Cz\$/kg. Médias anuais,

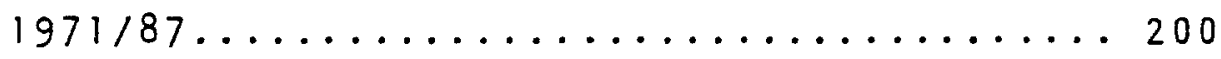

Parcelas absolutas de comercialização de carne bovina (média ponderada entre carne de primeira e de segunda) dos açougues e supermercados da cidade de São Paulo, em Czs/kg. Médias anuais, 1971/87.........201

Parcelas absolutas de comercialização de carne bovina de segunda dos açougues e supermercados da cidade de sãopaulo, em

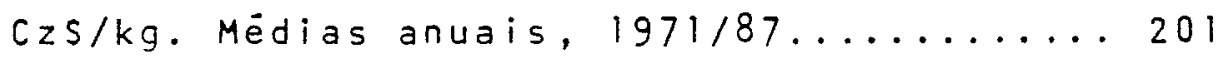


Parcelas absolutas de comercialização de carne bovina de primeira dos açougues e supermercados da cidade de São Paulo, em

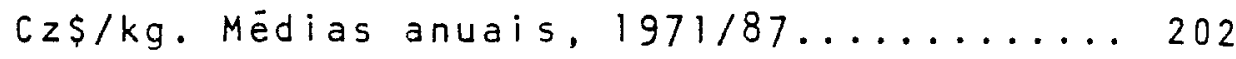

40 Parcelas absolutas de comercialização de carne bovina, em czs/kg. Mëdias mensais,

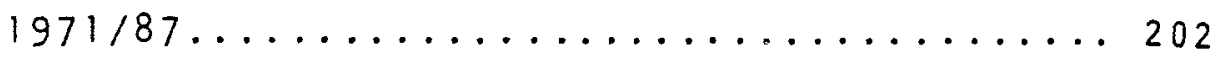

41 Parcela absoluta total de comercialização de carne bovina, em $c z \$ / k g$. Mèdias men-

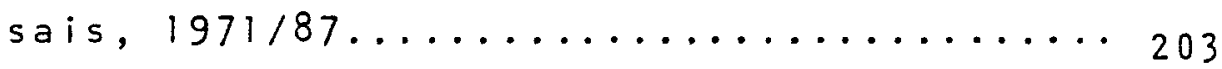

42 Parcelas absolutas de comercialização de carne bovina (média ponderada entre carne de primeira e de segunda) dos açougues e supermercados da cidade de São Paulo, em

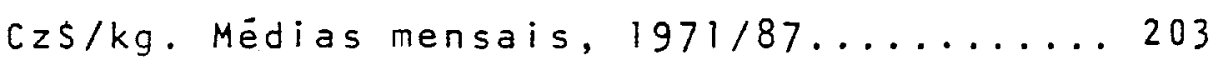

43 Parcelas absolutas de comercialização de carne bovina de segunda dos açougues e supermercados da cidade de são paulo, em Cz\$/kg. Mëdias mensais, 1971/87........204

44 Parcelas absolutas de comercialização de carne bovina de primeira dos açougues e supermercados da cidade de São Paulo, em

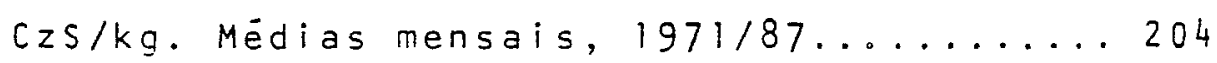


Margens absolutas de comercialização de carne bovina do atacado e varejo, em

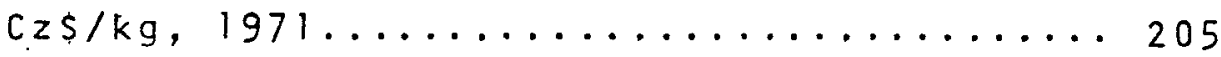

46 Margens absolutas de comercialização de carne bovina do atacado e varejo, em

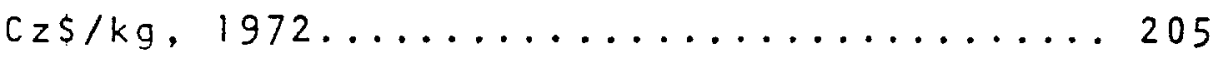

47 Margens absolutas de comercialização de carne bovina, 1983...................206

48 Margem absoluta total de comercialização de carne bovina, em $c z \$ / k g, 1971 \ldots \ldots \ldots 206$

49 Margem absoluta total de comercialização de carne bovina, em Cz\$/kg, 1972.......207

50 Margem absoluta total de comercialização de carne bovina, em $\mathrm{Cz} \$ / \mathrm{kg}, 1983 \ldots \ldots \ldots 207$

51 Preços médios mensais reais de carne bovina recebidos pelo mercado atacadista da cidade de São Paulo, em Cz\$/kg, 1971/87...203

52 Preços mëdios reais do boi gordo recebidos pelos produtores do Estado de São Paulo,

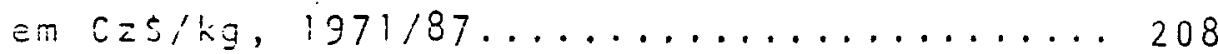

53 Preços mëdios reais de carne bovina recebidos pelo mercado varejista da cidade de

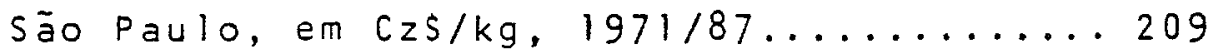


1 Rendimento e valores de carcaça bovina e subprodutos ao nivel de atacado, Estado de São Paulo, julho, $1970-72 \ldots \ldots \ldots \ldots$

2 Tränsito de bovinos destinados a São paulo, segundo a origem e finalidade $(1984) \ldots \ldots 38$

3 Trânsito de bovinos oriundos de São paulo,segundo a origem e finalidade (1984)........

4 Comparação de níveis de significāncia dos tes tes F na anälise de causalidade da carne bovina, atravēs de auto-regressões vetoriais compostas das variäveis $A, V$, e PSP, período

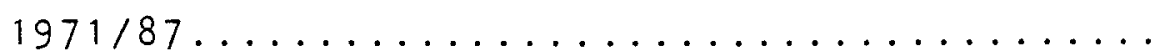

Comparação de níveis de significância dos tes tes F na anälise de causalidade da carne bovi na, atravës de auto-regressões vetoriais compostas das variäveis V e PSP, período 1971/

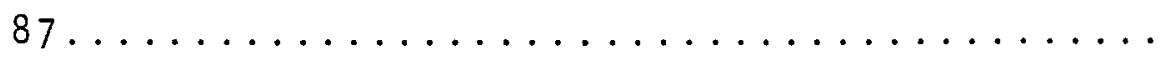


6 Níveis de significancia dos testes f na anäli se de causalidade da carne bovina atravēs de auto-regressões vetoriais, utilizando logarit mos naturais dos preços de mercado como filtro, periodo $1971 / 87 \ldots \ldots \ldots \ldots \ldots \ldots \ldots \ldots \ldots \ldots \ldots \ldots$

7 Testes para exclusão de variāveis futuras na anälise de causalidade da carne bovina, segun do mëtodo sugerido por BISHOP (1979), período $1971 / 87$ (12 e 140 graus de 1 iberdade $) \ldots \ldots$

8 Respostas a um choque de uma unidade em PSP ..

9 Respostas a um choque de uma unidade em $V$....

10 Respostas a um choque de uma unidade em A ... 90

11 Decomposição da variância dos erros de previsão (48 períodos). Ordenação: PSP, V, A ..... 96

12 Decomposição da variäncia dos erros de previsão (48 períodos). ordenação: A, V, PSP ..... 
Parcelas porcentuais. de comercialização de carne bovina. Mëdias anuais (1971/87), em $\% \ldots \ldots \ldots \ldots \ldots \ldots \ldots \ldots \ldots \ldots \ldots$

14 Preços médios anuais reais recebidos pelos mercados produtor paulista, atacadista e varejista da cidade de São Paulo,

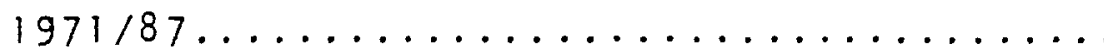

15 Parcelas porcentuais de comercialização de carne bovina dos açougues e supermercados da cidade de São Paulo, 1971/87. Mẹ

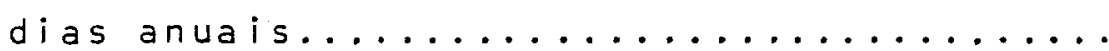

16

Parcelas porcentuais de comercialização de carne bovina de segunda dos açougues, e supermercados da cidade de São Paulo,

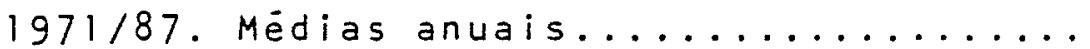

17 Parcelas porcentuais de comercialização de carne bovina de primeira dos açougues, e supermercados da cidade de são Paulo,

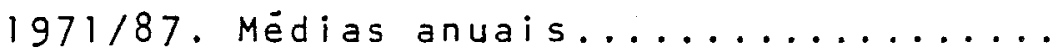

Parcelas porcentuais de comercialização de carne bovina. Médias mensais (1971/87),

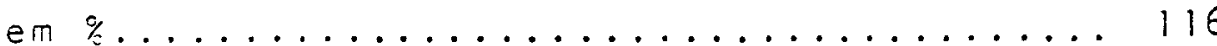


Parcelas porcentuais de comercialização de carne bovina dos açougues e supermercados da cidade de são paulo, 1971/87. Mé

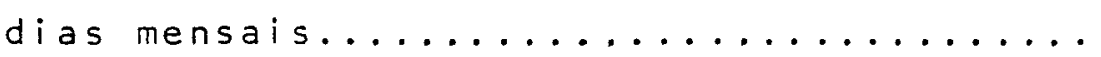

Parcelas porcentuais de comercializaçäo de carne bovina de segunda dos açougues e supermercados da cidade de São Paulo,-

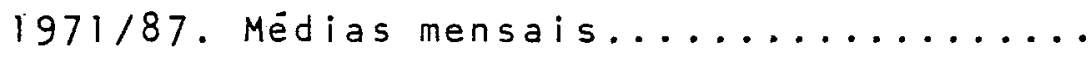

Parcelas porcentuais de comercialização de carne bovina de primeira, dos açougues e supermercados da cidade de Säo Paulo,

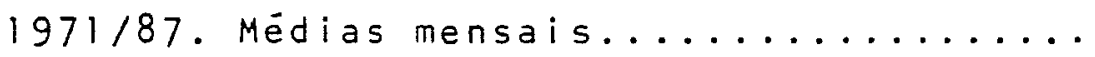

Margens correntes de comercialização de carne bovina, janeiro a dezembro de 1971... 128

23 Margens correntes de comercialização de carne bovina, janei ro a dezembro de 1972... 129

24 Margens correntes de comercialização de carne bovina, janeiro a dezembro de 1983... 130

25 Preços correntes do quartó dianteiro, recebidos pelo mercado atacadista de carne bovina da cidade de São Paulo, no período $1971 / 87$, encrs/kg...................153 
26 Preços correntes do quarto traseiro, recebidos pelo mercado atacadista de carne bovina da cidade de São Paulo, no período $1971 / 87$, em cr $\$ / \mathrm{kg} \ldots \ldots \ldots \ldots \ldots \ldots \ldots$

27 Preço corrente da carne bovina de segunda nos açougues da cidade de são paulo, no

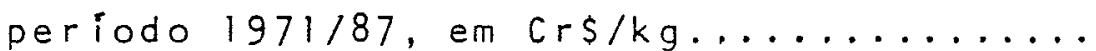

28 Preço corrente dos cortes de carne bovina de primeira nos açougues da cidade de São Paulo, no periodo 1971/87, em Cr\$/kg..... 156

29 Preços correntes de carne bovina, recebidos pelos açougues da cidade de são Pau10, no período 1971/87, em cr\$/kg....... 157

30 Preços correntes da carne bovina de segunda, recebidos pelos supermercados da cidade de São Paulo, no período 1971/87,

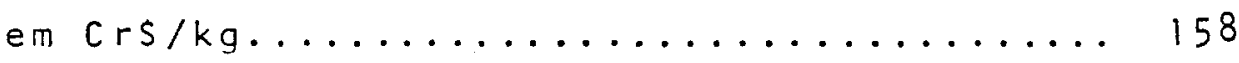

31 Preços correntes da carne bovina de primeira, recebidos pelos supermercados da cidade de são Paulo, no período 1971/87,

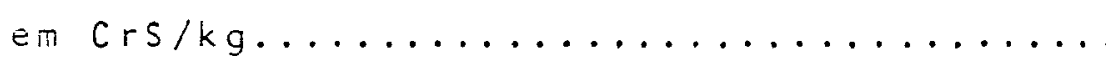


Tabela $n$ ?

Pägina

Preços correntes da carne bovina, recebidos pelos supermercados da cidade de são Paulo, no período $1971 / 87$, em cr\$/kg...... 160

33 Preços mëdios da carne bovina, recebidos pelos varejistas da cidade de São Paulo, no período $1971 / 87$, em $c r \$ / k g \ldots \ldots \ldots \ldots$

34 Preços correntes recebidos pelo produtor do Rio Grande do Sul, no período $1971 / 87$,

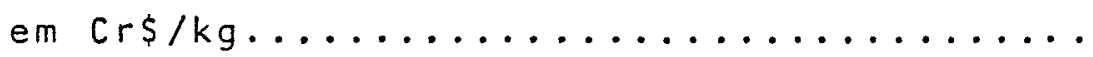

Preços correntes recebidos pelos produtores de boi gordo de Minas Gerais, no periodo $1971 / 87$, em $\mathrm{cr} \$ / \mathrm{kg} \ldots \ldots \ldots \ldots \ldots$

Preços correntes recebidos pelos produtores de Goiàs, no período 1971/87, em cr\$/kg............................ 164

37 Preços correntes recebidos pelos produtores de Mato Grosso, no período 1971/87, em $\mathrm{cr} \$ / \mathrm{kg} \ldots \ldots \ldots \ldots \ldots \ldots \ldots \ldots \ldots \ldots$

38 Preço corrente recebido pelo produtor de boi gordo do Estado de São Paulo, no periodo $1971 / 87$, em crs/kg............ 166 
Efeitos de um choque de uma unidade

41

Efeitos de um choque de uma unidade de desvio padrão em A sobre o sistema

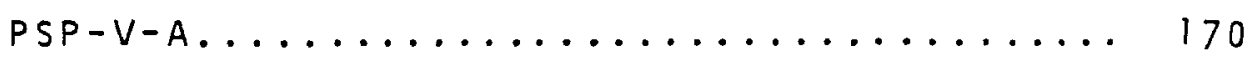

42 Efeitos de um choque de uma unidade de desvio padrão em PMT sobre o sistema PMT-V-A......................... 171

43 Efeitos de um choque de uma unidade de desvio padrão ém $V$ sobre o sistema $P M T-V-A \ldots \ldots \ldots \ldots \ldots \ldots \ldots \ldots \ldots \ldots$

44 Efeitos de um choque de uma unidade de desvio padräo em $A$ sobre o sistema

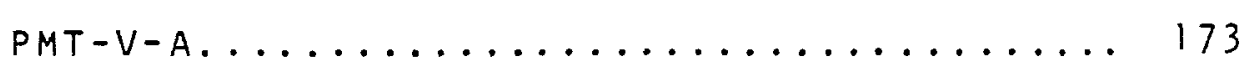

45 Efeitos de um choque de uma unidade de desvio padrão em PGO sobre o sistema

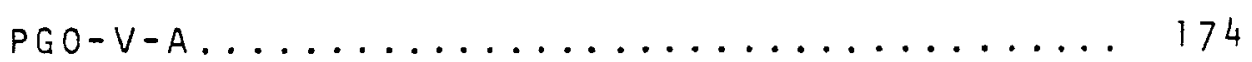


Tabela n?

Efeitos de um choque de uma unidade

de desvio padrāo em $V$ sobre o sistema $P G O-V-A \ldots \ldots \ldots \ldots \ldots \ldots \ldots \ldots \ldots$

Efeitos de um choque de uma unidade de desvio padrão em A sobre o sistema

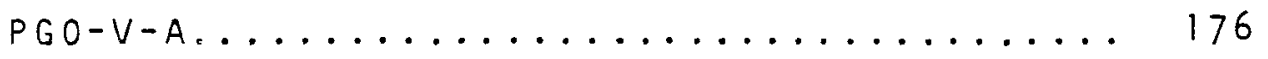

48 Efeitos de um choque de uma unidade de desvio padräo em PMG sobre o sistema

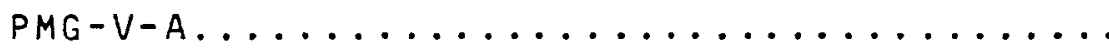

Efeitos de um choque de uma unidade de desvio padrão em $V$ sobre o sistema $P M G-V-A \ldots \ldots \ldots \ldots \ldots \ldots \ldots \ldots \ldots \ldots \ldots$

50 Efeitos de um choque de uma unidade. de desvio padrão em A sobre o sistema $P M G-V-A \ldots \ldots \ldots \ldots \ldots \ldots \ldots \ldots$

51 Efeitos de um choque de uma unidade de desvio padrão em PRS sobre o sistema PRS-V-A...................... 180

52 Efeitos de um choque de uma unidade de desvio padräo em $V$ sotre o sistema

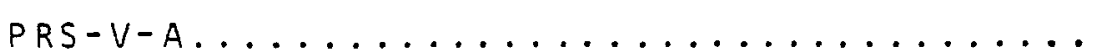


53 Efeitos de um choque de uma unidade de desvio padrão em A sobre o sistema PRS-V-A ........

54 Decomposição da variância dos erros de previsão (48 períodos). Ordenação: PMT, V, A .... 183

55 Decomposição da variância dos erros de previsão (48 períodos). Ordenação: A, V, PMT ..... 184

56 Decomposição da variância dos erros de previsão (48 períodos). ordenação: PGo, V, A .... 185

57 Decomposição da variância dos erros de previsão (48 períodos). ordenação: A, V, PGO .... 186

58 Decomposição da variância dos erros de previsão (48 períodos). ordenação: PMG, V, A....

59 Decomposição da variância das erros de previsão (48 períodos). ordenação: A, V, PMG .... 188

60 Decomposição da variância dos erros de previsão (48 períodos). Ordenação: PRS, V, A .... 189

61 Decomposição da variāncia dos erros de previsão (48 períodos). ordenação: A, V, PRS ..... 190

62 Parcelas absolutas de comercialização de caŕne bovina, em Cz\$/kg. Médias anuais (1971/87) 
Parcelas absolutas de comercialização de carne bovina dos açougues e supermercados da cidade de Säo Paulo, 1971/87. Mèdias anuais, em $c z \$ / k g \ldots \ldots \ldots \ldots \ldots \ldots \ldots \ldots \ldots \ldots \ldots$

64 Parcelas absolutas de comercialização de carne bovina de segunda, dos açougues e supermercados da cidade de São Paulo. 1971/87. Médias anuais, em Cz\$/kg........ 194

65 Parcelas absolutas de comercialização de carne bovina de primeira, dos açougues e supermercados da cidade de São Paulo, 1971/87. Mëdias anuais, em cz\$/kg........

66 Parcelas absolutas de comercialização de carne bovina, em $c z \$ / k g$. Mëdias mensais $(1971 / 87)$

67 Parcelas absolutas de comercialização de carne bovina dos açougues e supermercados da cidade de Säo Paulo, 1971/87. Médias mensais, em $c z \$ / k g \ldots \ldots \ldots \ldots \ldots \ldots \ldots$

Parcelas absolutas de comercialização de carne bovina de segunda, dos açougues e supermercados da cidade de são Paulo.

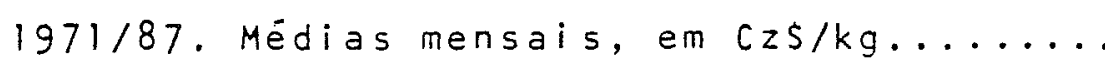


Tabela n:

Pàgina

69

Parcelas absolutas de comercialização de carne bovina de primeira, dos açougues e supermercados da cidade de são Paulo, 1971/87. Médias mensais, em cz\$/kg.......199 
TRANSMISSÄO dE PREÇOS DE CARNE BOVINA ENTRE NTVEIS DE MERCADO: UMA APLICAÇĀO DO MODELO DE AUTO-REGRESSĀO VETORIAL

Autora: FLÃVIA MARIA OE MELLO BLISKA Orientador: PROF. DR. GERALDO SANT'ANA DE C. BAPROS

RESUMO

o presente trabalho propöe-se a analisar a natureza das relaçōes de transmissäo de preços entre os níveis do mercado de carne bovina numa anälise ünica, estudar os mecanismos através dos quais se propagam os choques nesses preços, determinar a intensidade e duração desses choques e calcular margens de comercialização.

Partiu-se do pressuposto que as variaçöes de pré ços possam iniciar-se em qualquer nível de mercado (produtor,atacado ou consumidor), admitindo-se, portanto, que o sentido de causalidade entre os preços possa variar de acordo com a importáncia dos diferentes fatores ligados à oferta e demanda do pro duto.

Foi estimado um modelo de auto-regressäo vetoriai, com 12 meses de defasagem, constituído das variàveis preços do boi gordo a nível de produtor, preços da carcaça no ataajdo e preços da carne bovina no yarejo. Esse nodelo acesenis 
as vantagens de possibilitar a anälise de causalidade num conjun to de mais de duas variáveis numa anālise única e a obtenção de efeitos e duraçäo de choques em cada uma das variáveis consideradas sobre as demais.

o procedimento adotado consistiu em estimar os parámetros de uma representação auto-regressiva de um processo estocástico vetorial. Estudou-se os mecanismos de propagação. de choques através da obtenção dos coeficientes da representação de médias móveis e decomposição da variāncia dos erros de previsão k-periodos adiante, em percentagens a serem atribuidas aos choques em cada um dos processos componentes do modelo.

Utilizou-se, nos testes de causalidade, sëries de preços médios mensais reais recebidos pelos mercados atacadista - paulista, varejista da cidade de são paulo e produtores de boi gordo dos Estados de São Paulo, Minas Gerais, Goiás, Mato Grosso e Rio Grande do Sul, no perído de janeiro de 1971 a dezembro de 1987. Os testes mostraram os seguintes resultados:

1) Identificou-se efeito causal no sentido dos preços recebidos pelo mercado produtor de boi gordo paulista para os mercados varejista e atacadista e do mercado varejista para os mercados atacadista e produtor paulista;

2) Identificou-se efeito causal no sentido dos ní veis de atacado e varejo para os mercados produtores de boi gordo de Minas Gerais, Goíás e Mato Grosso;

3) Não foi observado efeito causal no sentido dos produtores de boi gordo de Minas Gerais, Goiás, Mato Grossoe Rio 
Grande do Sul para os mercados atacadista e varejista de São Paulo;

4) Passividade do atacado em relaçāo aos demais ní veis do mercado paulista de carne bovina;

5) Ausēncia de variävel essencialmente exōgena.

Analisando-se os mecanismos de transmissão de cho ques entre os preços, detectou-se causalidade instantànea entre as variàveis. Verificou-se que a intensidade dos efeitos de choques sobre os niveis de varejo e atacado decresce rapidamente, anulando-se todos os efeitos nos primeiros meses após um choque nos preços. Os choques a nivel de produtor de boi gordo, ao contrário, persistem por períodos mais longos.

As margens de comercialização foram denominadas parcelas, pois näo se computaram em seu cälculo os valores dos subprodutos bovinos. As parcelas interanuais do produtor e do atacado apresentaram comportamentos opostos. Nas fases ascendentes do ciclo de preços reais do boi gordo, a parcela do pró dutor cresceu, enquanto a do atacado decresceu; nas fases do ciclo em que a parcela do produtor cailu a do atacado elevou-se. Quanto às parcelas intra-anuais, a do produtor mos trou-se mais elevada na entressafra, quando os preços reais do boi gordo recebidos pelos produtores são mais elevados; a parce la do atacado, ao conträrio, foi menor nesse período.

As parcelas dos supermercados foram sempre inferio res às dos açougues, tanto em termos de carne de segunda como de primeira, embora tenham apresentado comportamentos semelhantes ao longo do período analisado, inter e intra-anualmente. 
TRANSMISSION OF BEEF PRICES BETWEEN MARKET LEVELS: AN APPLICATION OF THE AUTO-REGRESSIVE MODEL

Author: FLÁVIA MARIA DE MELLO BLISKA. Adviser: PROF. DR. GERALDO SANT'ANA DE C. BARROS

SUMMARY

This work intends to analyse the nature of prices transmission relations in the beef market levels in a single analysis, to understand the mechanisms through which shocks spread in those prices, to determine the intensity of the process and the shocks length and to calculate the marketing spreads.

The starting point has been the possibility of price variations starting in any market level (producer, consumer or wholesaler), thus admitting that the direction of the causality action among prices can vary according the relative importance of different factors related to the product's supply and demand.

A twelve month-lag vectorial auto-regression model was used, taking the following variables into account: farmer cattle prices, wholesale carcass prices and retail beef prices average. This mode1. presents advantages in what it makes possible the causality analysis in a set of more than two variables in a single analysis, the attainment of effects and the effects of each one of these variables over the others. 
The procedure adopted simply estimates the parameters of an auto-regressive representation of a vectorial. stochastic process. It studies the mechanisms of shock transmission through the coefficients of a moving average representation and breaking down the variance of errors in k-periods ahead,in terms of percentages to be attributed to the shock prices actions in each one of step followed in the model.

In the causality effect tests, the series of real average monthly prices used were based in säo paulo wholesale market prices, São Paulo city beef prices at the retail level, and cattle prices at the farmer levels at the states of sāo paulo, Minas Gerais, Goiäs, Mato Grosso and Rio Grande do Sul from january 1971 to december 1987. The causality test showed the following results:

1) It was identified the causality action as deriving primarily from prices at the são paulo cattle market to the beef retail market and to the carcass market and to the são Paulo cattle prodocer market;

2) It was identified the causality action as deriving from São Paulo wholesale market prices and retail beef prices to the Minas Gerais, Goiās and Mato Grosso farmer cattle prices;

3) It wasn't observed the causality action from Minas Gerais, Goiäs, Mato Grosso and Rio Grande do Sul's farmer cattle prices to the são Paulo wholesale carcass and to the são Paulo retail beef prices;

4) Wholesale carcass market passiv ty towards the other levels of the são Paulo market; 
5) Absence of essentially exogenous variable.

Through the analysis of shock transmission mechanisms among the prices, an instantaneous causality among the variables was detected.

It was observed that the intensity of prices shock effects upon wolesale carcass and retail beef levels decreases quickly, nullifying all effects in a few months after a shock. Inovation at farmer cattle level prices, on the contrary, lasts during longer periods.

Marketing spreads were called shares because cattle by-product values have not been added to its calculation. Farmer cattle and wholesale carcass market inter-annual shares presented oposite behavior. During the increasing stage of fat steer real price cycle, the farmer's share increased, while wholesale market share decreased; during the stages in which the farmer's share decreased, the wholesale market share rose up.

Concerning intra-annual shares, the farmer's one washigher in the period out of season, when fat steer real prices got by farmers are higher; the wholesaie market share, on the contrary, was smaller during this period.

Supermarket shares have always been lower than those concerning butcher's shops, either for choice meat or for ordinary meat; although both have presented similar behavior. inter-annually or intra-annually. 
1. INTRODUÇÃO

1.1. Importáncia do Problema

A presente pesquisa se preocupa com o processo de transmissão de preços de carne bovina durante sua comercialização. Esse processo sé associa à apropriação pelos agentes intermediàrios de uma margem relativa a custos e lucros, cuja determinação é de interesse tanto dos planejadores econômicos como do püblico em geral.

A carne bovina possui grande importāncia na alimentação humana, constituindo-se no principal item de despesa dos orçamentos familiares com alimentação; cerca de $25,5 \%$ das despesas monetärias por família da regiāo da cidade de são Paulo correspondem a carnes e pescados (FUNDAÇĀO INSTITUTO BRASILEIRO DE GEOGRAFIA E ESTATISTICA, 1978). A carne bovina, um dos itens da dieta básica do povo brasileiro, ocupa o primeiro lugar no consumo de carnes na cidade de São Paulo, sendo responsável por cerca de $10,3 \%$ das despesas com a cesta de mercado de uma família paulistana de renda e tamanho mëdios, isto é, 4 pessoas e 7,8 salärios mínimos (INSTITUTO DE ECONOMIA AGRICOLA, Outubro de 1985 e juiho de 1988). 
Sendo a carne bovina um produto de tal importância social e económica e cujo mercado tem proporcionado sérios problemas para os administradores da política agrícolanacional, é importante o estudo das alterações do preço desse produtoe da forma como essas alterações se transmitem entre os ${ }^{\circ}$ diferentes niveis de mercado, especialmente por se tratar de um setor que tem sofrido seguidas intervenções para controle tanto de preços como de margens de comercialização, as quais são de grande importância na formação dos preços pagos pelos consumidores e recebidos pelos produtores.

o mercado brasileiro de carne bovina tem sido objeto de inumerāveis estudos, principalmente relativos à produção e comercialização da carne. No entanto, são poucos os trabalhos recentes que analisaram direta ou indiretamente os relacionamentos entre os diferentes níveis de mercado.

o mercado em preço caracteriza-se por osci lações estacionais e plurianuais na oferta do produto, condicionadas pe los fenómenos da passagem da safra para a entressafra e do ciclo pecuārio,ocasionando períodos de alta e baixa nos preços.

A flutuação da oferta, provocada pela dicotomia safra-entressafra, decorre da passagem de um período do ano com reduzido suprimento de forrageiras para um período em que ocorre aumento do volume oferecido. Na época em que se inicia a que da na quantidade e no valor nutricional produção forrageira, - abate de bois cresce para evitar perdas de peso, provocando queda dos preços, caracterizando o final da safra (fevereiro-ju 
1ho). Na entrada do período das äguas, a produção forrageira aumenta, os produtores passam a reter o gado para obter maior peso e a oferta se reduz, com consequente elevação dos preços, caracterizando a entressafra (agosto-janeiro). (ADABO,1980; NAS CIMENTO, 1981).

A variação estacional no abate e no preço doboi gordo no Estado de São Paulo, para o período $1980-84$, està representada na figura 1 .

Tndices percentuais

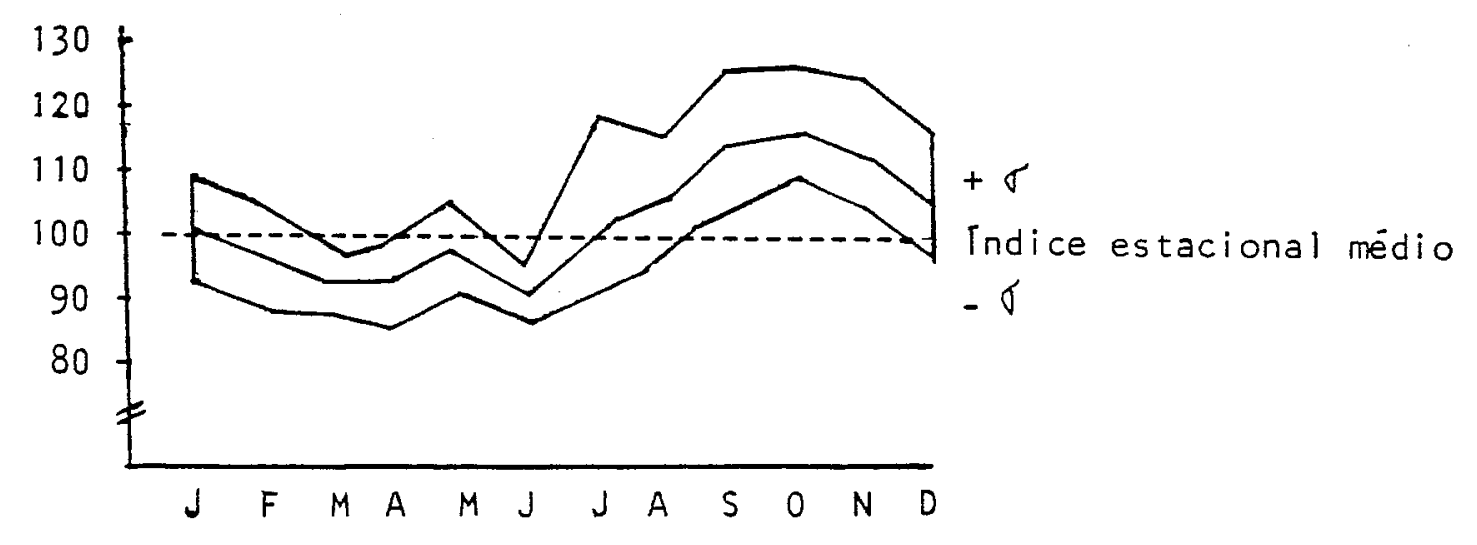

Figura 1. Variação estacional dos preços recebidos pelos produ tores de boi gordo, Estado de São Paulo, 1980-84. Indice de irregularidade igual a um desvio padrão( $\sigma)$.

Fonte: SÃo PAULO (1986), Secretaria da Agricultura, Institü to de Economia Agrícola, Agricultura: Situação e pers pectiva $(p .106)$. 
preço das vacas em relação às expectativas de preço futuro de bois gordos. Em fase de preço declinante do boi gordo, o pecuarista projeta a tendéncia para o futuro, provocando que da no valor atual de matrizes, aumentando a quantidade de ma trizes e bezerros enviados para abate, acentuando a tendéncia de baixa nos preços pelo excesso de oferta. Cerca de dois anos apös o início dessa fase descendente ocorre escassez de boi gordo, revertendo as tendéncias e elevando os pre ços. Com a elevação de preços, inicia-se maior retenção de matrizes e bezerros, ocasionando elevação de preços que, no futuro, ocasionam novamente excesso de oferta e inicio de nova. fase de preço declinante, e assim sucessivamente (DIAS, 1972 ; MASCOLO, 1979; NASCIMENTO, 1981 ; GARCIA, 1984 ;MUELLER, $1987)$.

A variação cíclica na pecuäria de corte nacio nal estä exemplificada na figura 2 (reproduzida de MUELLER, 1987), referente ao período 1950/85. Nesta figura observa-se que o preço real recebido pelos produtores do Estado de São Paulo apresenta flutuações, porēm sempre em torno de uma ten dência crescente, sendo possível identificar ao menos seis ciclos no período analisado. A sērie de preços do boi gordo recebidos pelos orodutores foi deflacionada pelo IGP-DI da Fundação Getulio Vargas, para dezembro de 1985. 


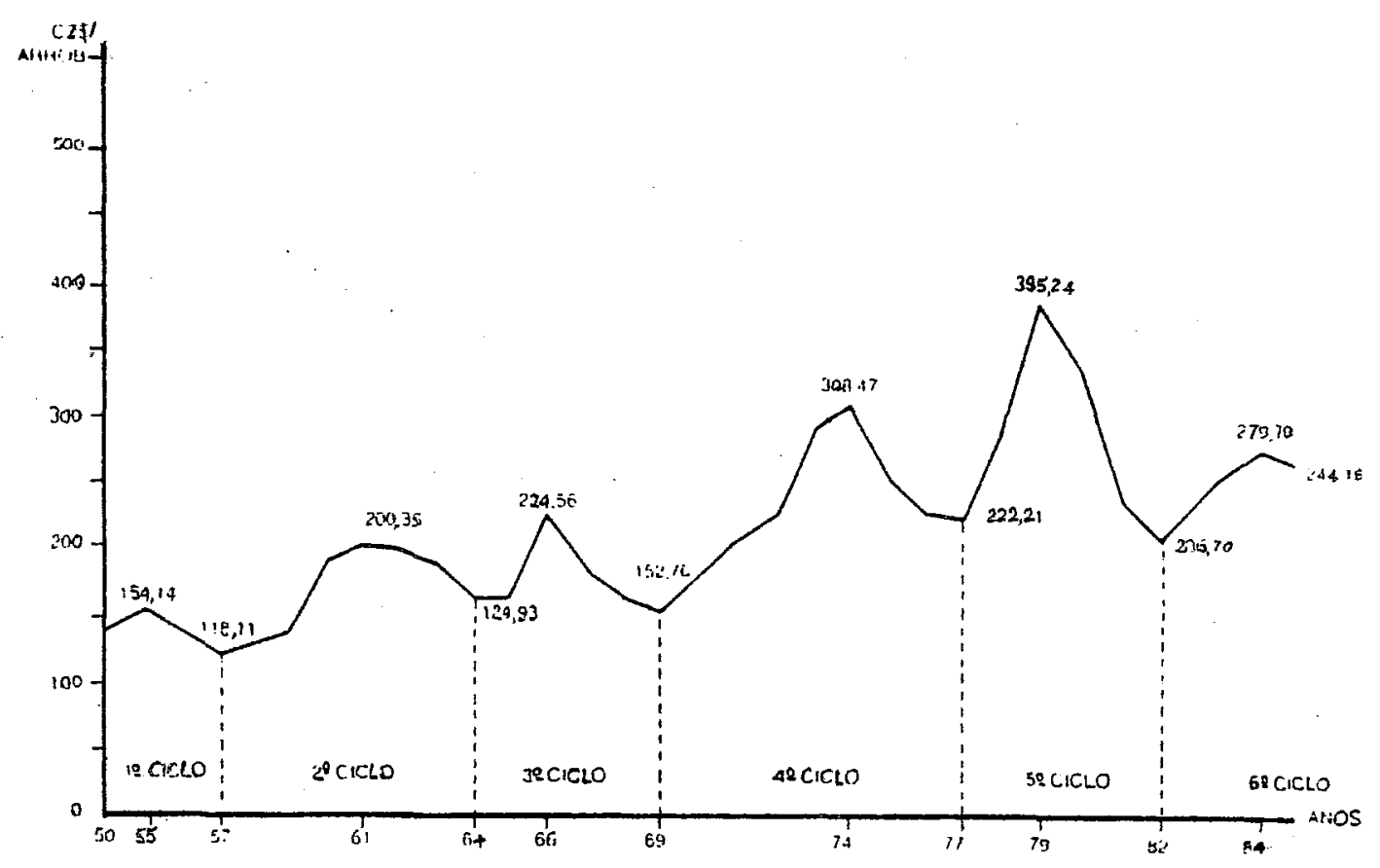

Figura 2. Estado de São Paulo: evolução dos preços reais recebidos pelos produtores de boi gordo, $1954 / 85$. Fonte: MUELLER (1987, p. 437).

Para melhor compreensão do comportamento dos preços nos diversos níveis de mercado é importante o adequado conhecimento da estrutura do mercado em apreço, o qual associa-se a diversas atividades intermediárias, como formação das pastagens e produção de forrageiras para corte, si lagem e fenação.

A nivel de produtor o animal pode passar por transações de compra e venda, características da estrutura da produção pecuäria do Estado de São Paulo, normalmente dividida em trés fases - cria, recria e engorda-que refletem a especialização das empresas pecuärias em função da localizaçäo geogräfica da propriedade. 
A atividade de cria corresponde ao fluxo de produção de bezerros ou garrotes obtidos de um estoque de ma trizes e dependente da taxa de natalidade e do estoque de ma trizes. Os bezerros permanecem nessas empresas normalmente até os 12 ou 18 meses, quando são vendidos ao recriador. A fase de recria utiliza como insumo principal os bezerros da fase de cria e gerabois magros, retendo os animais por período de 1 a 2 anos. A ültima fase da produção, a engorda, utiliza os bois magros como principal insumo, gerando bois para abate; essas empresas (invernistas) retém os animais por período de 8 a 12 meses. Hä empresas pecuārias que se verticalizam na produção, atuando nas fases de cria-recria ou mesmo nas fases cria-recria-engorda (santiago citado por $A D A B O, \quad 1980)$.

O sistema de comercialização da carne bovina inicia-se a nível de produtor com a venda do boi gordo ao frigorifico, diretamente ou através de compradores assalaria dos ou comissionados enviados pelos frigorificos às fazendas.

Os agentes atacadistas säo os frigorificos, en trepostos e distribuidores. Os agentes varejistas são os açougues/casas de carne, supermercados e clientes institucio nais (redes de hotéis e restaurantes, hospitais, etc). As

SANTIAGO, A,R. Pecuària de corte no Brasil centrai - São Paulo, Instituto de Zootecnia, 1970. 
compras a nível de atacado correspondem principalmente aos quartos de carcaça bovina (dianteiros e traseiros), sendo os cortes exigidos a nivel de consumidor realizados no próprio equipamento varejista.

A literatura indica que nos ültimos anos os frigoríficos tēm se localizado mais pröximos às zonas de pró dução. As grandes empresas possuem entrepostos de comercialização para receber e armazenar carcaças em grande escala, utilizam-se de serviços dos distribuidores e, devido a sua escala de produção, podem eliminar alguns custos administrativos. Em geral, os distribuidores são apenas prestadores de serviços na distribuição das carcaças, exercendo influencia muito pequena na formação dos preços do atacado. Os frigoríficos, ao contrário, são os compradores do boi @ordo, exercendo poder muito maior na formação daqueles preços. Os frigorificos menores distribuem diretamente aos pontos de venda varejista.

O mercado atacadista é constituído por pequeno número de agentes económicos, opera comprodutos considerados bons substitutos entre si e cuja diferenciaçào geralmente está ligada aos serviços e facilidades de venda que cada empresa oferece. Especializando-se no comércio de um nümero limitado de produtos, o setor aparenta deter volume maior e melhor de informações, ao conträrio dos secores de produção e varejo, normalmente não especializados e operando 
em pequena escala.

Alguns trabalhos, como MASCOLO (1979) e ADABO (1980), constataram a existência de um sistema oligopsonista dos frigoríficos em relação aos produtores e oligopolista em relação aos varejistas. Adabo apresentou dados de abates sob inspeção federal, para o período $1974 / 79$, que evidenciam ele vada concentração dos abates de toi gordo a carao de um núme ro reduzido de frigoríficos. Nos anos de $1977 / 79$ essa concen tração manteve-se mais forte, sendo que cerca de $33 \%$ dos fri goríficos foram responsāveis por $53,88 \%$ dos abates em 1978 ; em 1979 esses nümeros passaram, respectivamente, para $24 \%$, com $51,80 \%$ dos abates.

o mercado varejista apresenta estrutura mais atomizada, havendo grande nümero de pequenos estabelecimentos. A maior parte da carne bovina consumida na cidade de São Paulo, 77,00\% segundo a Pesquisa de orçamentos Familiares (POF) realizada pela FIPE/USP, em 1981/82, é adquirida em açougues/casas de carne, sendo os $23,00 \%$ restantes adquiridos em supermercados. Hä algumas redes de supermercados e açougues/casas de carnes, caracteristicos de mercado imperfeito, pórém com menor grau de concentração que o mercado atacadista, apresentando menor poder de ditar preços devido à existência de certa concorrência.

Em função das considerações apresentadas, con clui-se que oscilaçōes de preço de carne tovina podem se ori 
ginar a priori em qualquer dos níveis de comercialização. Sendo a produção de carne sujeita a ciclos bem marcantes, po der-se-ia supor que as variações de preços se originassem predominantemente a nivel de produção. Todavia, sendo o setor de atacado oligopolizado, é possível que as oscilações de produção se reflitam sobre os preços na dependēncia da atuação dos atacadistas. Por exemplo, os atacadistas podem al terar os preços em funçäo de suas expectativas de escassez ou abundância em antecipação da ocorréncia efetiva das mesmas. Finalmente, não se pode descartar a possibilidade de que oscilaçōes de preços possam se iniciar no varejo, principalmente por ser a carne um produto de elasticidade- renda de demanda relativamente elevado. Nessas condiçöes,variaçöes de renda associadas ao comportamento dos salärios e emprego podem ocasionar variações de demanda e consequentemente de preços no varejo.

Com esta pesquisa pretende-se identificar os niveis de mercado onde tendem a se iniciar as oscilaçóes de preços de carne bem como o grau em que essas oscilações são transmitidas de um nivel para outro de mercado. 
os objetivos principais dessa pesquisa são analisar a natureza das relações de transmissão de preços da carne bovina entre níveis de mercado (produtor, atacado e va rejo) numa anälise ünica; estudar os mecanismos através dos quais se propagam os choques nesses preços; determinar a intensidade e duração desses choques; e calcular margens de co mercialização. No estudo serão utilizados séries de preços mëdios reais mensais a nível de produtor, atacado e varejo, referentes ao mercado da cidade de são paulo, no período de janeiro de 1971 a dezembro de 1987.

1.3. Revisão de Literatura

D'APICE E JUNQUEIRA (1972) descrevem as carac teristicas do comércio varejista, politicas de comercialização e formas de organização dos estabelecimentos distribuido res de carne na cidade de São Paulo para o ano de 1970, utilizando-se de amostragem estatistica. Dando continuidade a esse estudo, D'APICE PÁEZ(1978) analisa a produção, capacidade 
produtiva, comercialização e rentabilidade do Parque Industrial de Carne Bovina em São Paulo, apresentando dados sobre distribuição dos frigorificos dentro do Estado, produção e distribuição de carne e rendimento dos miüdos bovinos relat i vos ao período $1971 / 73$. Alguns destes resultados estão repre sentados na Tabela 1.

As conclusões do trabalho de D'APICE PÄEZ são resumidas a seguir:

a) No período $1970 / 72$ foi constatada a existência de aproximadamente 500 unidades de abate de bovinos no Estado de São Paulo, responsáveis pelo abate de cerca de 2 milhões de animais;

b) A capacidade ociosa de abate no auge da sạ fra, em 1972, para as unidades operando sob inspeçäo federal, foi de $18 \%$

c) 0 abate concentrou-se nas mãos de $2 \%$ das empresas existentes no Estado de São paulo, as quais responderam por até $42 \%$ dos abates, correspondendo àquelas de maior grau de complexidade e de diversificação da produção, responsāveis pela exportaçāo internacional e em geral com ca pacidade diäria de abate superior a 500 cabeças;

d) As empresas mais rudimentares, cujas ativi dades essenciais corresponderam à distribuiçäo de carnes frescas nos limites municipais e com capacidade de abate diá 
rio geralmente inferior a 100 cabeças, representaram $87 \%$ do total de empresas em operaçäo e foram responsäveis por apenas $22 \%$ dos abates do Estado;

e) As empresas que comercializaram predominan temente carnes frigorificadas no mercado estadual e interestadual, com capacidade de abate diärio entre 101 e 200 cabeças, representando $5 \%$ do total de empresas existentes, foram responsàveis por até $32 \%$ dos abates;

f) As empresas que apresentaram maior grau de complexidade e diversificação da produção, mas que não operam no mercado internacional, responderam por cerca de $11 \%$ dos abates;

g) A DIRA 'de são paulo, em relação às demais, concentrou a maior parte dos abates realizados no Estado;

Quanto às carnes "in natura" e demais produtos cärneos produzidos pelas unidades de abate sob inspeçäo federal, no período em estudo, verificou-se que, quantitativamente, a maior parte da produção foi comercializada sob a forma de carne "in natura", principalmente carne resfriada com osso,

D.I.R.A. : Divisão Reaional Aarícola 
ficando em segundo lugar em importancia a carne congelada com osso.

Tabela 1 .- Rendimento e valores de carcaça bovina e subprodutos ao nível de atacado, Estado de São Paulo, julho, 1970-72.

\begin{tabular}{|c|c|c|c|c|}
\hline & Rend. & valor & total & $(\mathrm{Cr} \$)$ \\
\hline$P \subset s a$ & $\begin{array}{l}\text { mento } \\
\text { medio }\end{array}$ & $\begin{array}{l}\text { Julho } \\
1970\end{array}$ & $\begin{array}{l}\text { Julho } \\
|97|\end{array}$ & $\begin{array}{l}\text { Julhe } \\
1972\end{array}$ \\
\hline \multicolumn{5}{|l|}{ Carcaca } \\
\hline $\begin{array}{l}\text { Traseiro } \\
\text { Dianterto } \\
\text { Ponta de agulha }\end{array}$ & $\begin{array}{l}110 \mathrm{hg} \\
90 \mathrm{hg} \\
30 \mathrm{~kg}\end{array}$ & $\begin{array}{r}207.00 \\
162.00 \\
47.70\end{array}$ & $\begin{array}{l}462.00 \\
288.00 \\
78.00\end{array}$ & $\begin{array}{r}517.00 \\
333.00 \\
89.10\end{array}$ \\
\hline Sub-iotal & & 500,70 & $8 \geq 8.00$ & 939.10 \\
\hline
\end{tabular}

Subproduto comestivel

\begin{tabular}{|c|c|c|c|c|}
\hline Figade & $3.7 \mathrm{~kg}$ & $9.6 ?$ & 10,54 & 12.82 \\
\hline Ling ua & 1 pesa & 2.75 & 3. ?:1 & 4.32 \\
\hline Buche & $4 \mathrm{~kg}$ & 5.40 & 6.80 & 9.00 \\
\hline Corasac & 1 pesa & 1.90 & 1.90 & 2.38 \\
\hline Ratiada & $1 \mathrm{~kg}$ & 3.65 & 3.65 & 4,32 \\
\hline Rıns & 2 pesas & 0.44 & 0.90 & 1.04 \\
\hline Mocotós & 4 peç2s & 4.84 & 5.35 & 6.72 \\
\hline Mrolos & 3 pecas & 0.48 & 0.48 & 0.68 \\
\hline Sub-total & & 29,06 & $3 \geq 82$ & 41.28 \\
\hline
\end{tabular}

Subproduto não comestivel

\begin{tabular}{|c|c|c|c|c|}
\hline $\begin{array}{l}\text { Couro } \\
\text { Farinha (carne) } \\
\text { Sebo } \\
\text { Biles. casco, chifres. } \\
\text { ćlculos e pelos }\end{array}$ & $\begin{array}{l}35 \mathrm{~kg} \\
2 \mathrm{~KB} \\
13 \mathrm{~kg} \\
\text { (conjunto) }\end{array}$ & $\begin{array}{r}41,30 \\
1,00 \\
6,24 \\
0,92\end{array}$ & $\begin{array}{r}50.75 \\
0.90 \\
-8.06 \\
1.48\end{array}$ & $\begin{array}{r}84,00 \\
1,24 \\
12,22\end{array}$ \\
\hline Sub-10:2l & & 49,46 & 61,19 & 99.56 \\
\hline Total & & 585.24 & 922.01 & 1079,94 \\
\hline
\end{tabular}

Fonte: Instituto de Economia Agrícola, in D'APICE PĀEZ (1978, p. 104). 
o Conselho Nacional de Desenvolvimento da Pecuária(CONDEPE), BRASIL (1979), realizou diversos trabalhos enfocando o comportamento dos preços da pecuāria bovina de corte para o Estado de são Paulo, contendo informações conjunturais das cotações do boi gordo, cotações anuais de preços no atacado e cālculos das suas variaçōes. Esses trabalhos fornecem dados do Estado como um todo e tambëm a nível das Regiöes pecuárias Brasileiras, porēm sem apresentar caräter analítico.

A Associação Brasi leira da Indūstria de Armazenagem Frigorificada (AB|AF), 1982, publicou alguns estudos sobre - mercado de carne bovina, ressaltando a situação em que o mercado se encontra e suas perspectivas, com objetivo de for necer subsídios para melhor acompanhamento do setor, mas tam bēm sem caräter analítico.

Entre os estudos com objetivo de analisar políticas governamentais adotadas para o setor pecuärio brasileiro, destaca-se o de nASCIMENTo (1981), cujo estudo compreende o período de 1970/77. Segundo Nascimento, o Governo Federal geralmente interfere no mercado de carne bovina, com o objetivo de estabilizar as flutuações de oferta ed de preço atravēs do sistema de estoques reguladores de carne congelada, utilizando matadouros-frigorificos particulares e a rede estadual e federal de armazēns frigoríficos. 0 autor avalia, segundo a teoria dos estoques reguladores de carne bovina, o tamanho dos estoques e a mobilização financeira governamental em diversas alternativas de intervenção. Foram 
estimadas e analisadas as funções sazonais de oferta e uma funçāo de demanda de carne bovina. De acordo com as anälises de Nascimento, a oferta de bovinos para abate foi classifica da como preço-inelàstica a curto prazo e relativamente preço inelàstica a longo prazo, pois foram encontradas elasticidades - preço de 0,06 a curto prazo e de 0,17 a longo prazo. As curvas de oferta de bovinos para abate situaram-se em niveis signíicativamente diferentes nos periodos de safra e entressafra, mas não apresentaram inclinações significativamente diferentes nas duas épocas. Para a equação de demanda de carne bovina foi encontrada elasticidade-preço de - 2,6 a curto prazo, indicando que a procura do produto é muito sensivel às yariações de preços.

Alguns autores que estudaram margens de comer cialização da carne bovina foram CAMARGo (1968), JUNQUEIRA et alii (1968), CARMO (1969), JUNQUEIRA E CANTO (1971), ViEIRA \& RENESTO (1977), ADABO (1978 e 1980) e CANTO (1986).

CAMARGO(1968) estudou a comercializaçào da carne bovina na cidade de Belo Horizonte, no ano de 1967, calculou a margem de comercialização dos frigoríficos que estudou e a margem total de comercialização. O autor verificouque a margem média de comercialização para os frigoríficos estudados foi. mator nas entressafras $(24, i 7 \%)$ do que nas safras $(18,37 \%)$. A margem total de comercializạ̧ão em relação ao 
preço pago pelo consumidor final foi subdividida em: $60,57 \%$ para o produtor; $3,96 \%$ para comissöes, transportes e impostos; $13,49 \%$ para os frigorificos; $22 \%$ para os acougues.

Em JUNQUEIRAet ali i (1968) enfatiza-se a necessida de de estudos sistemáticos da eficiência do sistema de comer cialização de carnes, principalmente nos aspectos ligados à distribuiçäo varejista, por considerar este o segmento do fluxo que responde pela maior parcela da margem total de coretcializaçác. Esse trabalho considera cue, fará grande parte dos produtos agrícolas do Estado de são faulo, é a ní vel de varejo que se concentram as maiores despesas de comer cialização. Os autores determinararr margens de conercializa çào do arroz, feij̄̄o, milho, batata e cebola e estucarar as variaçōes anual e estacional dessas margens. As. Frincipais conclusōes do estudo forár:

a) Há grance oscilaçào do nivel perceritual das riargens durante o período estudado;

b) A marger de varejo é a maior entre os co merciantes;

c) Os produtos pereciveis (bataie e cebola) parecer. possuir una elevada marger de comercializaço no varejc, nivel em que ocorrem maiores perdas;

d) As rargens de carercielizaça sojo reletive mente mais rigidas que os preços agrícolas;

e) As margens de comercializaçào tèrn relasăo 
direta com o volume das safras e portanto apresentam rela cäo inversa comi o nível de preços;

f) $\mathrm{Na}$ formaçä́o do preço dos produtos estuda dos a influéncia do mercado atacadista é bemi grande, estando os presos dos miercados produtor e varejista intimarente asso ciados ao atacado.

CARMO (1969), alér de determinar riargens de comercializaçàc de carne bovina, determinou a natureza da política de margens adotadas pelos comerciantes atacadistas e varejistas. O autor analisol tamber o suprimento de carne bovina à cidade de sào paulo e identificou os principais p. blemas relacionados cori sua comercializasão, fazende suges töes pará sua soluçào.

JUNQUEIRA \& CANTO (1971) estudaram margens totais de comercialização, ao analisar a Cesta de Mercado para a cidade de São Paulo. Verificou-se que a margem de comercialização é tanto maior quanto maior for a exigência de processamento da matéria-prima agrícola. Os produtos farináceos apresentaram a maior margem de comercializaçäo, ao redor de $82 \%$ do preço do varejo, enquanto que no grupo de aves e ovos a margem gira ao redor de $32 \%$. No grupo das carnes, a margem de comercialização foi em média de 19,5\%. A margem total de comercialização apresentou menor flexibilidade que os preços no varejo.

VIEIRA \& RENESTO (1977) detiveram-se na ca- 
racterizaçāo dos estabelecimentos varejistas de carne no mu nicipio de Campinas e na mensuraçäo do nível de reação dos comerciantes a propostas de inovaçōes sugeridas pela pesquisa tecnológica na àrea da carne e pelas tendências do comércio de carne bovina em países desenvolvidos. Calcularam margens diferenciadas a nivel de equipamento varejista (açougue e supermercado) e regionalmente, isto é, a cidade em anälise foi subdividida em regiōes com diferentes níveis de poder aquisitivo (regiāo l - classes de renda baixa e mẹ dia; região 11 - classes de renda média-alta e alta; região $|1|-$ centro).

As principais conclusões desse trabalho são:

a) Entre açougues e supermercados não ficaram evidentes diferenças na tecnologia empregada na comercializa ६̧äo da carne bovina natural;

b) Em geral os supermercados dispöem de instalaçõs mais modernas, nem sempre utilizadas adequadamente;

c) A utilização de mão de obra familiar é maior nos açouques que nos supermercados;

d) A escala de operação dos supermercados é bem superior à dos açougues;

e) A margem de comercialização nos supermercados é, en méaia, interior à dos ąudules, faso gue parece estar correlacionado à escala de corerciailizasáo;

f) Cerca de 304 toneladas semanais de carne 
bovina sajo manuseadas pelos varejistas do municipio de cam pinas; 58 c desse total cabe aos supermercados;

g) Quanto as inovaçōes tecnológicas, os su permercados náo se mostraram mais receptivos do que os acoun gues;

h) Constatou-se umá reaçào contrária às inova çóes tecnológicas provocada por total desinformaçáo dos me canismos que regerian tais mudangas e das suas imflicaçōes tecnológicas e económicas na atividade. Concluiu-se pela necessidade de maior divulgaşa de informaçōes referentes a esses aspectos da investigacāo cientifica entre esse segmento da indústria de carne, como essencial na promosajo de melhor receptividade de inovasōes no processo de comercia lizaçào;

i) Tanto supermercados quanto açougues declä raran benéfica a liberaçäo do preço dos cortes de novilho precoce;

j) Os supermercados considerarar benéfica a comercialização de carne pré-embalada, enquanto cerea de 93\% dos acougues consideraram-na prejudicial, apontando como principais barreiras ao seu desenvolvimento, os hábitos e a desconfiança dos consumidores.

O estudo de rarçens de coretcializascáo de car ne bovina na cidade de Säo Pailo realizado por ADABO (1978), 
para o perfodo de 1971/77, procurou identificar a existéncia ou nāo de tendēncia das margens ao longo do tempo. o autor discutiu a relação entre as margens do produtor e as margens totais de comercialização com o ciclo de preços da pecuäria de corte.

Os principais resultados do trabalho sāo:

a) As margens totais de comercializaçāo da carne bovina consumida na cidade de säo Paulo decresceram de 48\% para 36\% no período 1971/74, e oscilaramentre 46\% e 39\% no período $1975 / 77$;

b) A margem total média de comercializaçāo pạ ra o período $1971 / 77$ foi estimada em $42 \%$

c) As margens do produtor cresceram de $52 \%$ para $64 \%$ no período $1971 / 74$, e de $1975 / 77$ cresceram de $54 \%$ para $61 \%$;

d) A margem média do produtor no período $1971 / 77$ foi estimada em $58 \%$;

e) Na fase ascendente do ciclo de preços reais do boi gordo $(1971 / 74)$, as margens do produtor acompanham esta ascendéncia. Na fase descendente (1975/77) essas margens säo. inferiores àquelas observacias ria fase anterior, exceto para o ano de 1975, com leve tendēncia aocrescimento;

f) Nos anos de áscensāo dos preços reais a ní vel de varejo $(1971 / 74)$, houve elevação média mais que proporcional nos preços reais do boi gordo recebidos pelos pro- 
dutores, induzindo uma participaçäo maior do produtor no preço final do produto. Nos anos de queda dos preços reais a nivel de varejo (1975/77) houve queda mais que proporcional nos preços reais do boi qordo, gerando queda nas maraens do produtor;

g) Os coeficientes de variação das maraens to tais de comercialização e das margens do produtor, no período $1971 / 77$, foram de $9,86 \%$ e $7,14 \%$, respectivamente;

h) As margens do produtor näo apresentaram uma tendéncia estatisticamente significativa no período em anàlise ;

i) No estudo intra-anual das margens de 1971/77, as margens totais de comercializaça foram superiores à média no período da safra; na entressafra essas maraens foram inferiores à mèdia;

i) As margens totais de comercialização para o período 1971/77 tambèm não apresentaram tendéncia estatisticamente significativa;

Em trabalho posterior, de 1980 , ADABO oferece uma visão das principais causas do comportamento de preços da carne bovina na cidade de São Paulo, no período 1968/79; procurou ainda identificar alguns dos principais fatores de formacão dos precos de atacado e vareio, bem como as políticas de margens permitidas pelo mercado varejista.

Algumas conclusões do autor são: 
a) O mercado atacadista é oligopolizado;

b) os preços de atacado e varejo acompanham o movimento cíclico dos preços do boi gordo a nível de produ tor;

c) Os graus de oligopölio do mercado atacadis ta, como uma aproximação dos "markups" de aiacado, afresentar. relaçào inversa com o movimento cíclico dos preşos do boi ocodo.

SOUZA (1974) estudou algurs aspectos da pró duçào e comercializa̧āo de gado e carne. Na fase de comer cialização de carne procurou analisar os agentes e as fun çöes de comercializaça e estutou as particularidades dos sistemas de comercializasăo de carne, identificando suas de ficiēncias'e formulando sugestōes para melhorar a eficiēn cia do mercado. Aigumas das sugestēes do autor para sanar alquns dos problemas que afetam. a produça e comercializa. çào de carne elou melhorar sua eficiència säo apresentadas a seguir:

a) Substituisão dos matadouros municipais por matadouros regionais ber localizados e bem aparelhados para melhor aproveitamento dos subprodutos;

b) Permissão pará construção de novos estä belecirentos abenas depois de estudo cetalhado sobre sua viabilidade e rentatilidade;

c) Financiamento para modernização do parcue 
industrial de carne;

d) Ampliação da inspeçāo sanitäria federal a todos os estabelecimentos produtores de carne e que comer cializam produtos cärneos;

e) Repressão severa ao abate clandestino;

f) Incentivo à maior oferta de gado gordo na entressafra;

g) Providéncias no sentido de reduzir a co mercialização de carne verde, promovendo aumento da oferta de carne frigorificada ou em conserva;

h) Empenho para realizaçāo da desossa e limpe $z$ a das carcaças nos matadouros e não nos açougues;

i) Estimulo à comercializaçäo de carne desos sada, acondicionada em embalagens plásticas, fechadas a váa cuo, com: a identificaçōo e caracteristicas do corte;

j) Adoção do sistema de classificação e tipi ficação de carcaças, a fim de permitir maior cotaçäo para os produtos de melhor csalidade;

k) Severa fiscalização nos veículos que trang portam carne.

Um dos trabalhos recentes sobre pecuäria bovi na é o de KASSOUf (1988), onde sāo analisadas sēries de pré sos reais mensais do dezerro, doi ragro e arroba do boi gor do, no período de janeiro de 1970 a dezembro de 1986, obser vando as variaçóes existentes e ajustando alguns modelos pa 
ra séries temporais, com o objetivo de obter previsões de preços na pecuária de corte do Estado de São Paulo.

A autora aplicou o método de Box e Jenkins à sé rie dos logaritmos dos preços da arroba do boi gordo. 0 melhor ajustamento obtido foi um modelo $\operatorname{SARIMA}(0,1,1)$ (auto-regressi vo-integrado-de-mēdias-möveis sazonal), porém este modelo não forneceu boas previsões de preços, não conseguindo captar as variações cíclicas plurianuais com período de aproximadamente 6 anos. Todos os modelos empregados forneceram previsões mensais de preços da arroba do boi gordo para o ano de 1987. Essas previsões e os preços obtidos em negociações no mercado a termo do boi gordo da Bolsa de Mercadorias de São Paulo foram com parados aos preços do mercado físico, para verificação do seu desempenho.

0 modelo auto-regressivo $A R$ (2) forneceu as melhores previsões, vindo a seguir o modelo misto auto-regressivo e de médias móveis ARMA $(1,1)$, as previsöes do mercadoa ter mo, o modelo harmônico e o SARIMA $(0,1,1)(0,1,1) 12$.

o modelo misto com AR (2) foi ajustado à série de preços em questão num período mais longo, prevendo preços de de 1981 a 1987, ano a ano. Estas previsões e as previsões fornecidas pelo mercado a termo foram comparadas aos preços do mer cado físico. No mercado a termo as previsões foram melhores em 5 dos 7 anos; nos anos de 1982 e 1983 as melhores previsões fo ram do modelo misto com AR (2). 
Baseando-se nos resultados obtidos, KASSOUF(1988) concluiu que as previsöes de preços obtidas na Bolsa de Mercadorias de são paulo säo muito boas e refletem os preços do mercado físico.Verificou-se que os preços do bezerro poderiam ser previslos a partir das previsōes de preso para o boi me gro, através de uma regressão, pois as duas séries de preços sào semelhantes. O modelo $A R(2)$ forneceu melhores previsōes dos presos do bezerro para o ano de 1981 , do que as previ sōes obtidas pela regressão com base nos preços do boi magro (as quais foram superiores para 1987 ).

No trabalho de CANTO(1986), foram calculadas as margens totais de comercializaço de carne bovina. Esse tra balho fornece parámetros para uso emi cálculo de transforma cōes, em peso, de diversos produtos alimenticios. sāo apre sentados coeficientes baseados em rendimentos industriais médios obtidos cor a tecnologia normalmente utilizada duran te a industrializasāo e comercializasajo dos produtos anali sados. 0 autor apresenta uma metodologia para cálculo mais adequado das margens de comercializaço e exemplos de seu cálculo para värios alimentos. As conversóes físicas e rendimentos industriais médios para o caso da carne bovina sào representados na figura 3 e a estrutura utilizada no cälculo das margens de comercializaçāo desse produto estäo na figura 4 , subdividida em $4 a, 4 b$ e $4 c$.

Recentemente, värios estudos de determinaçāo 


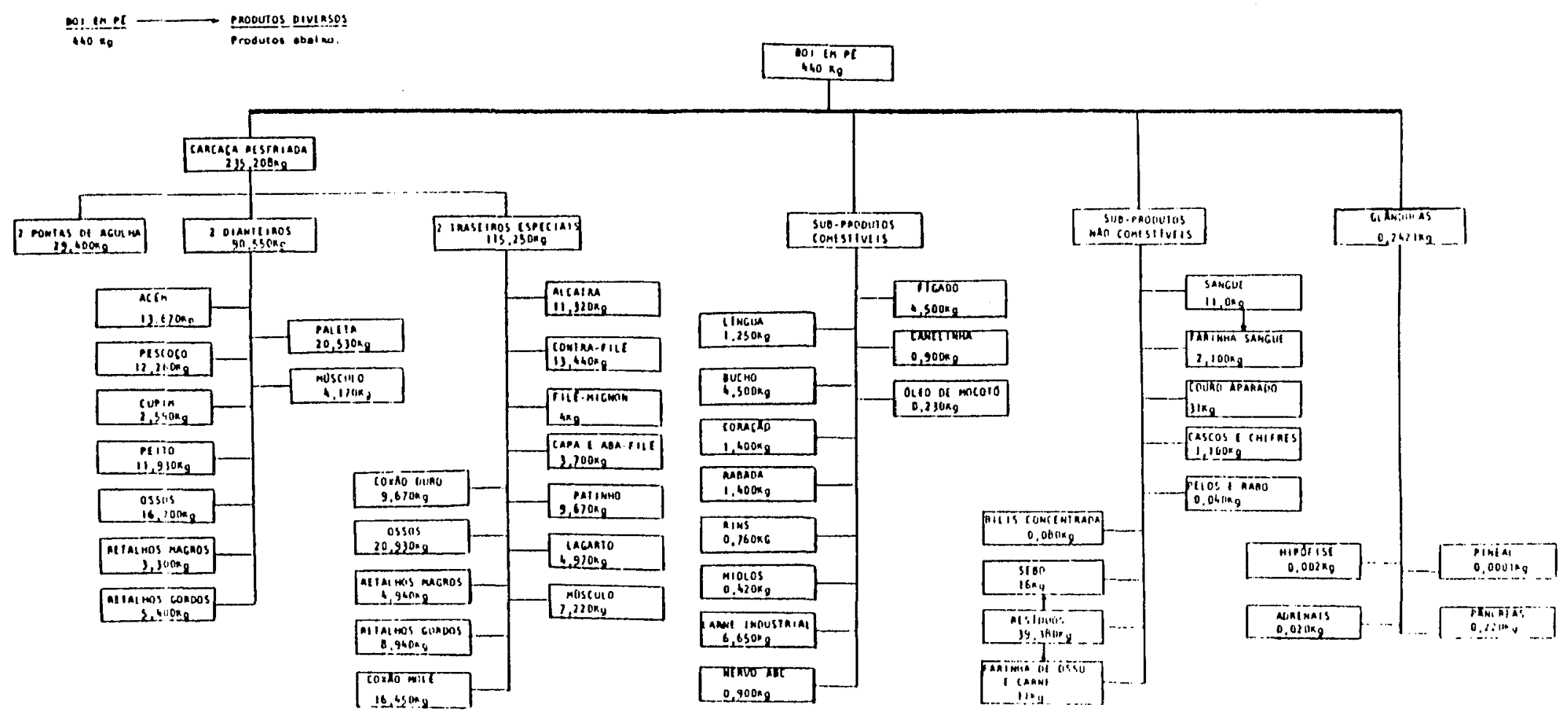

Figura 3. - Conversoos físicas e rendimentos industriais médins para a carne bovina. Fonte : CANTO (1986, p. 13) 
NIVEL DE ATACADO

\begin{tabular}{|c|c|c|c|c|c|c|}
\hline & $\begin{array}{c}\text { Partes } \\
\text { no } \\
\text { FRICORIfICO }\end{array}$ & $\mid \begin{array}{c}\text { PESO ME- } \\
\text { DIO kO OU } \\
\text { W: PEGAS } \\
(1)\end{array}$ & $\begin{array}{c}\text { PESO } \\
\text { CRS/kg } \\
(11)\end{array}$ & $\begin{array}{l}\text { valoR DUS } \\
\text { PARTES } \\
\text { (1) } \times(11) \\
\end{array}$ & $\begin{array}{l}3 \text { DAS PARTES } \\
\text { Mo vaLOR } \\
\text { TOIAL } \\
\text { IIIII } \\
\end{array}$ & 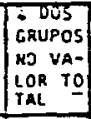 \\
\hline \multirow{3}{*}{. } & $\begin{array}{c}2 \text { TRASEIROS } \\
\text { ESPECIAIS } \\
\end{array}$ & 115.250 & 1.483 .00 & 170.915 .75 & 47,46 & \multirow{3}{*}{83.10} \\
\hline & $\begin{array}{c}2 \text { PONTAS OE } \\
\text { AGULHAS }\end{array}$ & 29,400 & 983,00 & $28.900,20$ & 8.02 & \\
\hline & 2 DIANTEIRO & 90.550 & 1.100 .00 & $99.605 . \infty$ & 27.64 & \\
\hline \multirow{10}{*}{ 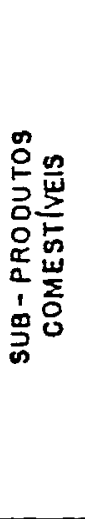 } & Bicsod & 4,500 & 1.267 .00 & 5.701 .50 & 1.59 & \multirow{10}{*}{6,04} \\
\hline & IImsua & 1 peca. & $1.017, \infty$ & $1.027,00$ & 0.28 & \\
\hline & $80 C 40$ & 4.500 & 683.00 & 3.073 .50 & 0.5 & \\
\hline & Conacho & 1 peca & 933,00 & $933, \infty 0$ & 0.26 & \\
\hline & RABADA & 1,400 & 1.650 .00 & $2.310,00$ & 0.64 & \\
\hline & Rins & 2 pecas & $240, \infty 0$ & 480,00 & 0.23 & \\
\hline & nocoto & 1 & $617 . \infty$ & 617,00 & 0,18 & \\
\hline & miolos & I & $240, \infty 0$ & $2<0,00$ & 0,07 & \\
\hline & $\begin{array}{l}\text { CARME } \\
\text { IMOUSIRIRL }\end{array}$ & 6.650 & 1.000 .00 & $6.650,00$ & 1,84 & \\
\hline & WE avo ABC & 0,900 & 766.00 & 689,00 & 0.20 & \\
\hline \multirow{8}{*}{ 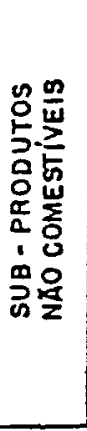 } & $\begin{array}{l}\text { FARIMHA Of } \\
\text { CARHE }\end{array}$ & 11 & $314, \infty$ & $3.454, \infty$ & 0.96 & \multirow{8}{*}{10,36} \\
\hline & $\begin{array}{l}\text { FARIMHA Of } \\
\text { SANGUE }\end{array}$ & 2.100 & 300.00 & 630.00 & 0.18 & \\
\hline & $\begin{array}{l}\text { COURO } \\
\text { APARADO }\end{array}$ & 31 & 733.00 & 22.723 .00 & 6.31 & \\
\hline & $\begin{array}{l}\text { CAscos E } \\
\text { CHIPRES }\end{array}$ & 1.100 & 22,00 & 24.20 & 0.01 & \\
\hline & $\begin{array}{l}\text { PELOSE } \\
\text { Raso }\end{array}$ & 0.040 & 7.500 .00 & 300,00 & 0,08 & \\
\hline & silus & 0.030 & 500.00 & 40,00 & 0.01 & \\
\hline & SEEO & 16 & 635.00 & 10.960 .00 & 3.04 & \\
\hline & $\begin{array}{l}\text { CALCULOS } \\
\text { - EMAIS }\end{array}$ & $.2 \times 10^{-1}$ & 4467000,00 & 992.66 & 0.27 & \\
\hline \multicolumn{4}{|c|}{ retess } & $360.256,21$ & 200 & 100 \\
\hline
\end{tabular}

NIVEL DO PRODUTOR,

\begin{tabular}{|c|c|c|c|}
\hline 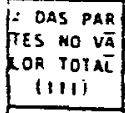 & $\begin{array}{l}\text { VALOR RECEBIDO } \\
\text { PELO PRODUTOR } \\
\text { PELAS CORTES } \\
(1111 \text { X S BOI }\end{array}$ & $\begin{array}{c}\text { PARTES } \\
D 0 \\
801\end{array}$ & \\
\hline 67.44 & 116.936 .94 & $\begin{array}{l}2 \text { TRASEIROS } \\
\text { ESPECIAIS }\end{array}$ & $-4 b$ \\
\hline 8.02 & 19.768 .86 & $\begin{array}{c}2 \text { PONTAS OE } \\
\text { AGG HA }\end{array}$ & \\
\hline 27.64 & 68.131 .05 & 2 OLAKIEIROS & \\
\hline 1.55 & 3.894 .61 & FIGADO & 1 \\
\hline 0.28 & 690.18 & Limgla & I \\
\hline 0.86 & 2.119 .86 & Bucho & 1 \\
\hline 0.26 & 640.88 & CORACAO & $i$ \\
\hline 0.64 & 1.577 .56 & GRSADA & $\begin{array}{l}1 \\
1\end{array}$ \\
\hline 0,13 & 320.64 & Rins & 1 \\
\hline 0.18 & 643.69 & mote & 1 \\
\hline 0.07 & 172.55 & noros & 1 \\
\hline 1.84 & 4.535 .50 & $\begin{array}{l}\text { CARME } \\
\text { IXE:STRIAL }\end{array}$ & 1 \\
\hline 0.20 & 492.99 & ME 2 NO ABC & 1 \\
\hline 0.96 & 2.366 .35 & $\begin{array}{l}\text { TARIYHA DE } \\
\text { CARME }\end{array}$ & 1 \\
\hline 0,18 & 663.69 & $\begin{array}{l}\text { FARIWHA Of } \\
\text { SAMGUE }\end{array}$ & 1 \\
\hline 6.31 & 15.553 .80 & $\begin{array}{l}\text { Coven } \\
\text { Dakeso }\end{array}$ & $i$ \\
\hline 0,01 & 24.65 & $\begin{array}{l}\text { Cescos E } \\
\text { ChifRES } \\
\end{array}$ & $i$ \\
\hline 0.08 & 197.19 & $\begin{array}{l}\text { PElos E } \\
\text { xuso }\end{array}$ & 1 \\
\hline 0.01 & 24.65 & oisis & $\begin{array}{l}1 \\
1\end{array}$ \\
\hline 3.04 & 7.493 .43 & SEN & i \\
\hline 0.27 & 665.53 & cilcuos & $i$ \\
\hline 100 & 246.494 .40 & TOTAIS & - \\
\hline
\end{tabular}

Figura 4a. - Estrutura utilizada no cälculo das margens de comercializaçäo de carne bovina.

Fnnte: CANTO $(1986, p .51)$. 
NIVEL DE VAREJO

\begin{tabular}{|c|c|c|c|c|c|}
\hline & $\begin{array}{l}\text { conves } \\
\text { no } \\
\text { acougur }\end{array}$ & \begin{tabular}{|l} 
pesso \\
NeO100 \\
$(19)$ \\
$(i v)$ \\
\end{tabular} & $\begin{array}{c}\text { enctco } \\
\text { casseg } \\
\text { ivi } \\
\end{array}$ & \begin{tabular}{|c|} 
valon \\
oos contes \\
inv) $x$ (v) \\
\end{tabular} & 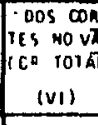 \\
\hline & Al catma & 11,320 & 2.613 .00 & 29367.84 & 6.53 \\
\hline \multirow{2}{*}{$\overline{5}$} & COMTRA-BIIE & 13,460 & 2.136 .00 & 36746.96 & 8.10 \\
\hline & Olli-nicnom & 4 & 1164.00 & $12.656,00$ & 2.79 \\
\hline \multirow{2}{*}{$\begin{array}{l}0 \\
a \\
n \\
0 \\
0\end{array}$} & cares ic & 3,700 & 1.966 .00 & 1.274 .20 & 1.60 \\
\hline & patinato & 9.670 & 2.332 .00 & 22.550 .64 & 4.97 \\
\hline \multirow{3}{*}{$\begin{array}{l}\text { o } \\
\text { L } \\
0 \\
\text { in } \\
0 \\
0 \\
\text { s }\end{array}$} & Iacarto & 4.970 & 2.436 .00 & 12.116 .86 & 2.67 \\
\hline & $\operatorname{mos} c u n o$ & 7.220 & 1.992 .00 & 14.382 .26 & 3.17 \\
\hline & COX & 9.670 & 2.350 .00 & 22.724 .50 & 5.03 \\
\hline & ossos & 20.930 & 175.00 & 3.662 .75 & 0.15 \\
\hline \multirow[t]{4}{*}{ N } & actian hos & 9.940 & 1.033 .00 & 5.103 .02 & 1.13 \\
\hline & $\begin{array}{l}\text { RENe Hos } \\
\text { conos }\end{array}$ & 8.940 & 1.033 .00 & 9.235 .02 & 2.03 \\
\hline & $\cos 20 \mathrm{NOLI}$ & 16,450 & 2.362 .00 & 38.054 .90 & 8.57 \\
\hline & rorals & 115.250 & & 216.872 .73 & 47.66 \\
\hline
\end{tabular}

NIVEL DO PRODUTOR

\begin{tabular}{|c|c|}
\hline 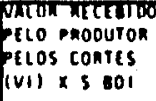 & 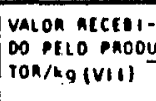 \\
\hline 16.096 .00 & 1.421 .91 \\
\hline 19.466 .04 & 1.465 .57 \\
\hline 6.877 .20 & 1.719 .30 \\
\hline 3.943 .91 & 1.065 .92 \\
\hline 12.250 .17 & 1.266 .56 \\
\hline 6.581 .40 & $1.324,22$ \\
\hline 7.813 .87 & 1.002 .00 \\
\hline 12.198 .67 & 1.282 .13 \\
\hline 2.095 .20 & 99.96 \\
\hline 2.785 .19 & 563.4 \\
\hline $5.003,4$ & 559.71 \\
\hline 21.124 .57 & 1.254 .17 \\
\hline 116.936 .94 & \\
\hline
\end{tabular}

MARGENS TOTAIS DE COMERCINUZACXOO

\begin{tabular}{|c|c|c|c|}
\hline \multirow{2}{*}{$\begin{array}{l}\text { contes } \\
\text { no } \\
\text { acougue }\end{array}$} & \multirow{2}{*}{$\begin{array}{c}\text { PAAT I C IDACAO } \\
\text { DO PROOUIOA } \\
11\end{array}$} & \multicolumn{2}{|c|}{$\begin{array}{l}\text { manGeP rolal } \\
\text { IVI: IVII. }\end{array}$} \\
\hline & & cos/to & \\
\hline ALCATRA & 54.6 & 1.190 .09 & 65.6 \\
\hline COMIRA-Fite & 56.36 & 1.248 .43 & 15.66 \\
\hline FILEMIGHON & 54.34 & 1.464 .70 & 45.66 \\
\hline $\begin{array}{l}\text { CADA E } \\
\text { ABA-FILE }\end{array}$ & 54.22 & 900.08 & 15.70 \\
\hline BAIINHO & 56.31 & 1.065 .42 & 45.69 \\
\hline LagaATO & 54.32 & 1.113 .78 & 45.66 \\
\hline MOSCuLO & 54.32 & 910.00 & 4.63 \\
\hline Co.en Duno & 56.56 & 1.067 .87 & 45.46 \\
\hline ossos & 51.12 & 75.06 & 42.00 \\
\hline $\begin{array}{l}\text { AETALNOS } \\
\text { magnos }\end{array}$ & 54.58 & 469.16 & 65.62 \\
\hline $\begin{array}{l}\text { METALNOS } \\
\text { GOMOOS }\end{array}$ & 54.18 & 43.29 & 65.02 \\
\hline CORAO-MOLE & 54.37 & 1.077 .83 & 15.63 \\
\hline
\end{tabular}

Figura 4b. - Estrutura utilizada no cälculo das margens de comercialização de carne bovina.

Fonte: CANT0 (1986, p.51). 
NIVEL DE VAREJO

\begin{tabular}{|c|c|c|c|c|c|}
\hline \multirow{4}{*}{ F } & $\begin{array}{l}\text { CORTes } \\
\text { no } \\
\text { A Gougue }\end{array}$ & \begin{tabular}{|c|} 
Pesso \\
MEDio \\
(kol \\
ing
\end{tabular} & $\begin{array}{c}\text { paeco } \\
\text { cus /us } \\
\text { (v) }\end{array}$ & $\begin{array}{l}\text { valog } \\
\text { oos conts } \\
(1 v) \times(v)\end{array}$ & 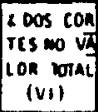 \\
\hline & acin & 13.670 & 1.780 .00 & 36.332 .60 & 5.20 \\
\hline & ef scoso & $|12.260|$ & 1.800 .00 & 22.060 .00 & 4.11 \\
\hline & ripin & 2.590 & 1.995 .00 & 5.167 .05 & 1.10 \\
\hline & perro & 11.930 & 1.725 .00 & 20.579 .25 & 4.40 \\
\hline & ossos & $16.700 \mid$ & 175.00 & 2.922 .50 & 0.621 \\
\hline & $\begin{array}{l}\text { afirathos } \\
\text { Machos }\end{array}$ & 3.300 & 1.033 .00 & 3.400 .90 & 0.13 \\
\hline & $\begin{array}{l}\text { MeTAl HoS } \\
\text { COADOSS }\end{array}$ & 5.600 & 1.033 .00 & 5.578 .20 & 1.20 \\
\hline & DMEIA & $20,530 \mid$ & $1.800,00$ & 36.956 .00 & 7.90 \\
\hline & misculo & 4.170 & 1.992 .00 & a. 306.64 & $1.76 \cdot$ \\
\hline & 1 & 90.550 & & 129.311 .16 & 27.64 \\
\hline
\end{tabular}

NIVEL DO PRODUTOR

\begin{tabular}{|c|c|}
\hline 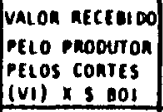 & 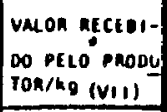 \\
\hline 12.017 .71 & 937.05 \\
\hline 11.609 .00 & 966.97 \\
\hline 2.711 .43 & 1.046 .00 \\
\hline 10.045 .75 & 909.12 \\
\hline 1.528 .26 & 91.51 \\
\hline 1.799 .41 & 545,28 \\
\hline 2.957 .91 & 547.76 \\
\hline $19.473,08$ & 948,52 \\
\hline 4.387 .60 & 1.052 .18 \\
\hline 68.131 .05 & \\
\hline
\end{tabular}

MARGENS TOTAIS DE COMERCIMUIACTO

\begin{tabular}{|c|c|c|c|}
\hline \multirow{2}{*}{$\begin{array}{l}\text { CORTES } \\
\text { no } \\
\text { agougue }\end{array}$} & \multirow{2}{*}{$\begin{array}{l}\text { Panticipacio } \\
\text { oo phoduton } \\
\text { 1/ }\end{array}$} & \multicolumn{2}{|c|}{$\begin{array}{l}\text { makele rotal } \\
\text { (vil) - (v) }\end{array}$} \\
\hline & & chsiag & \\
\hline acten & 52.60 & $8+2.35$ & 47.32 \\
\hline - escoco & 52.61 & 053.03 & 47.19 \\
\hline cupin & 52.48 & 968.12 & 47.52 \\
\hline Peito & 52.70 & 115.86 & 47.30 \\
\hline ossos & 52.29 & 03.49 & 1.11 \\
\hline $\begin{array}{l}\text { RETALNOS } \\
\text { MAGAO }\end{array}$ & 52.79 & 407.11 & 01.21 \\
\hline $\begin{array}{l}\text { AETALHOS } \\
\text { CORDOS }\end{array}$ & 53.03 & 405,26 & 06.91 \\
\hline PALETA & 52.10 & 051.41 & 47.30 \\
\hline mosculo & 52.02 & 939.02 & 47.18 \\
\hline
\end{tabular}

Ficilra $4 \dot{c}$. Estrutura utilizada no cālculo das margens de comercialização de carne bovina.. ronte: CALTO $(1986, p .51)$. 
de preços e margens de comercializaçäo de produtos agrícolas em geral foram realizados e testes de causalidade entre variàveis económicas tém sido utilizados para determinar relaçōes de causa e efeito sob um aspecto dinämico do sistema econömico (SIMS, 1972; HEIN, 1980; TEIXEIRA, 1982; BRANDAO, 1985 ; BURNQUIST, 1986 ; BARROS \& MARTINES F\%, 1987; MARTINES Fọ, 1988). Alguns destes estudos utilizaram um modelo de equi líbrio estätico baseado na pressuposição de equilibrio instantáneo de oferta e procura, nos niveis de varejo, atacadoe produtor (GARDNER, 1975), enquanto outros se utilizaram de um modelo de desequi líbrio para determinação de preços e mar gens, desenvolvido por HEIN (1980), tambëm englobando os níveis de varejo, atacado e produtor.

Diversos estudos relacionados aos preços e margens dos mercados agrícolas consideram como um pressupos to a relação de exogeneidade dos preços de compra em relação aos preços de venda. Outros consideram a relação de exogeneidade dos preços de venda em relação aos preços de compra. Mais recentemente alguns estudos têm procurado não só determinar o sentido de causalidade como também examinar a possibilidade de variações na relação causa-efeito ao longo de de terminado período. Tais estudos, entretanto, por limitaçós metodológicas, puderam analisar a causalidade apenas entre pares de preços (varejo x atacado, atacado x produtor, produ tor $x$ varejol, não se podendo estabelecer o encadeamento das 
variações dos preços entre os värios niveis de mércado numa anälise ünica.

A possibilidade de mudança no sentido de causalidade entre os preços agrícolas decorre de que o mecanismo através do qual ocorre a formação e transmissão de preços pode sofrer choques em diferentes niveis de mercado, assim como a própria estrutura de mercado e o grau de intervençào governamental nos mercados agrícolas podem variar. Conforme essas mudanças se verifiquem, podem ocorrer alteraçöes nos mecanismos de transmissäo de preços que induzam a mudanças no sentido de causalidade entre esses preços.

Os trabalhos publicados por GRANGER (1969) e por SIMS (1972) tornarami frequentes a utilização dos modelos auto-regressivos nas anälises destinadas a determinaçäo do sentido de causalidade entre veriäveis económicas. As anälises realizadas através de modelos de auto-regressäo veto rial (SIMS, 1980; BESSLER, 1984 ; CHAMBERS, 1984 e BRANDAO, 1985), permitem não só consideraçöes em termos de causalidade entre variäveis, mas tambëm a elaboraçäo de previsöes acerca dos efeitos de choques (inovaçōes) em cada uma das va riàveis consideradas sobre as demais. Dessa forma, são obti das a intensidade e duraçäo dos efeitos de choques, permitin do melhor compreensão da dinàmica dos fenómenos económicos e possibilitando a análise de causalidade num conjunto de mais de duas variàveis. 
o trabalho de SIMS $1(1972)$ envolve o problema da exogeneidade ou não da moeda em relação à renda. Nesse trabalho o autor desenvolveu um teste empírico para anali sar direção de causalidade entre variáveis económicas, consí derando que se e somente se o sentido de causalidade for uni camente dos valores presentes e passados de uma série de variáveis exógenas para uma dada variável endógena, tem-se que, numa regressajo da variável endógena com valores passados, pre sentes e futuros das variáveis exógenas, resultariam valoras nulos para os coeficientes futuros das variáveis exógenas.

$$
\text { Os trabalhos de HEIN (1980) e TEIXEIRA (1982) }
$$

empregam o método de sims para fins de determinação de elasticidade de transmissāo de preços, admitindo-se que a politi ca de preços adotada pelas firmas seja estabelecida através de aplicaçōes de mark-up sobre os preços de compra, prevalecendo com isso o sentido de causalidade do produtor para o a tacado e deste para o varejo.

Em 1980 sims desenvolveu uma anälise de processos auto-regressivos e sugeriu a realizaçāo do teste de Razäo de Verossimilhança para estabelecer o numero de defasa gens relevantes para os dados em questão, pois para realizaçäo de testes de causalidade ë primeiramente estabelecido o nümero de defasagens a ser considerado, através de um proces so de comparação de um sistema irrestrito (com maior número de defasagens) contra um outro sistema no qual um conjunto 
de defasagens è excluído (restrito).

Em BESSLER (1984), CHAMBERS (1984) e BRANDÃO

(1985) a metodologia em apreço é utilizada no estudo de ques tões da neutralidade da moeda em relação aos preços relativos da economia. 
2. MATERIAL E METODOS

2.1. Dados Bàsicos

A presente pesquisa utilizou-se de diversas sëries de preços de carne bovina, aos niveis de produtor, atacado e varejo, obtidas junto ao Instituto de Economia Agrí cola (IEA) e Fundação Getülio Vargas (FGV), no período de ja neiro de 1971 a dezembro de 1987. Todas as sēries foram deflacionadas pelo IGP (demanda interna) da FGV, para dezembro de 1987 .

Aos niveis de produtor e de atacado, os preços säo publicados em CrS/15 kg. Estespreços foram, entäo, transformados em Czs/kg, para se tornarem compatíieis com a unidade de comercializaçāo utilizada no varejo.

1

Optou-se pela utilização de um índice que pudesse ser utilizado na defla ção de todas as séries de preços empregadas nas anālises. 0 deflacionamento dessas séries por diferentes índices setoriais poderia aumentar a ocorrēncia de distorções nas anälises. 
A figura 5 representa o fluxograma de comer- cialização da carne bovina na cidade de são Paulo. A "produçāo pecuäriall engloba criador, recriador e invernista, responsāveis respectivamente pela cria, recria e engorda dos animais. A seguir, o animal pronto para o abate é enviado aos frigorificos. Dos frigoríficos a carne passa para os agentes distribuidores ou é enviada para indústrias ou comércio externo. O distribuidor leva a carne até os inümeros agentes varejistas, representados pelos supermercados, açougues, casas de carne e clientes institucionais, abastecendo o mercado interno. A carne industrializada pode ser enviada para exportaçäo ou para consumo no mercado interno.As eventuais importaçōes são realizadas pelo Governo, através da COBAL,e/ ou por grandes redes de supermercados.

\subsubsection{Preços a nível de produtor}

Foram coletados os preços médios mensais do boi gordo para corte, recebidos pelos produtores dos Estados de São Paulo, Goiás, Mato Grosso, Mato Grosso do Sul, Minas Gerais e Rio Grande do Sul.

Verificou-se junto a téenicos do IEA que o produtor paulista contribui no abastecimento do mercado consumidor em anälise com a parcela mais significativa, encontrando-se o Estado de são paulo bem próximo da auto-súficién 


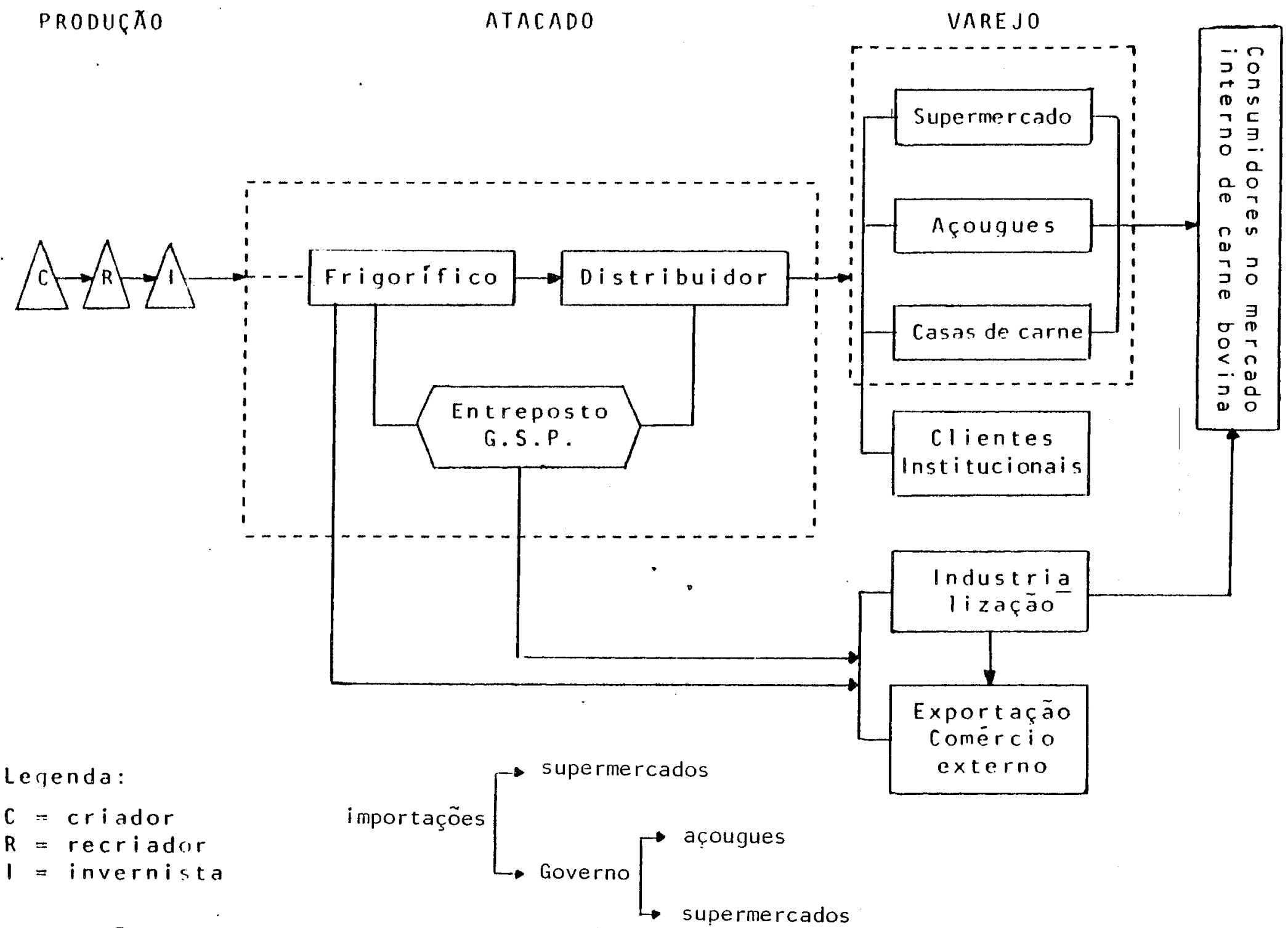

Figura 5. Fluxograma de comercialização da carne bovina na cidade de São Paulo.

Fonte: Adaplado de ADABO (1980, P. 41). 
cia em termos de produçāo de carne bovina.

No entanto, hä trânsito de bovinos entre o Estado de São Paulo e diversos outros Estados da Federação. o trânsito de bovinos destinados a são paulo e o trânsito de bovinos oriundos de São Paulo durante o ano de 1984 são apre sentados nas tabelas 2 e 3 . Atravēs desses dados observa-se que hä gado oriundo de são Paulo sendo abatido em outros Estados e gado de outros Estados sendo abatido em são paulo. Do gado destinado ao Estado de Säo Paulo em 1984 , cerca de $43,8 \%$ é proveniente de Mato Grosso do Sul, $33,4 \%$ de Goiás, $14 \%$ de Minas Gerais, 6,1\% de Mato Grosso, 2,4\% do Paraná, $0,2 \%$ do parà e $0,02 \%$ do Rio Grande do Sul.

Para obter uma série de preços que permitisse uma análise significativa do problema proposto, foram utilizadas publicaçōes da fundaçāo Getülio Vargas (FGV) - Preços Recebidos pelos Agricultores - as quais permitiram a obtenção de sēries de preços para o período de janeiro de 1971 a dezembro de 1987. Esses preços são coletados nos diferentes municípios, a seguir são transformados em média aritmética simples para microrregião em relação à unidade da federação em termos de quantidade produzida. 
Tabela 2. - Tränsito de bovinos destinados a sào Paulo, segundo a origem e finalidade, em 1984.

\begin{tabular}{|c|c|c|c|c|c|}
\hline $\begin{array}{c}\text { U. FEDERAÇĀO } \\
\text { (Origem) }\end{array}$ & CRIA/RECRIA & ENGORDA & ABATE & $\begin{array}{l}\text { REPRODUÇĀO } \\
\text { FEIRAS/EX- } \\
\text { POSIÇOES }\end{array}$ & TOTAL \\
\hline ALAGOAS & 3 & - & - & - & 3 \\
\hline BAHIA & 1.318 & - & 57 & - & 1.375 \\
\hline D. FEDERAL & - & - & - & 24 & 24 \\
\hline ESPIRITO SANTO & 28 & - & 93 & 21 & 142 \\
\hline GOIAS & 106.992 & 20.910 & 427.787 & 12.857 & 568.546 \\
\hline MARANHĀO & 121 & 23 & 61 & - & 205 \\
\hline MATO GROSSO & 22.700 & 8.833 & 78.453 & 2.514 & 112.500 \\
\hline MATO GROSSO SUL & 93.238 & 68.381 & 560.820 & 54.842 & 777.281 \\
\hline MINAS GERAIS & 27.745 & 2.982 & 179.670 & 3.903 & 214.300 \\
\hline PARA & 828 & 1.291 & 2.442 & 269 & 4.830 \\
\hline PARA IBA & 27 & - & - & - & 27 \\
\hline PERNAMBUCO & - & - & - & $\varepsilon$ & 8 \\
\hline PIAUT & 6.736 & 21 & 20 & - & 6.777 \\
\hline PARANA & 23.021 & 1.693 & 30.955 & 23.445 & 79.114 \\
\hline RIO DE JANEIRO & 12 & - & 40 & 136 & 188 \\
\hline RONDONIA & 32 & - & 41 & - & 73 \\
\hline RIO GRANDE SUL & 3.942 & 2.128 & 237 & 597 & 6.904 \\
\hline SANTA CATARINA & 991 & 37 & 50 & 122 & 1.200 \\
\hline SERGIPE & 38 & - & - & - & 38 \\
\hline TOTAL & 287.772 & 106.299 & .280 .726 & 98.738 & 1.773 .535 \\
\hline
\end{tabular}

Fonte: SÃo PAULO, 1984 (Serviço de Defesa Sanitäria Animal) 
Tabela 3. - Tránsito de bovinos oriundos de Sác, Paulo, segundo a origem e a finalidade, em 1984.

\begin{tabular}{|c|c|c|c|c|c|}
\hline $\begin{array}{r}\text { U. FEDERACAO } \\
\text { (Dest ino) }\end{array}$ & $C R|A / R E C R| A$ & ENGORDA & ABATE & $\begin{array}{l}\text { REPRODUCAO } \\
\text { FEIRAS/EX- } \\
\text { POSICOOES }\end{array}$ & TOTAL \\
\hline$\overline{A C R E}$ & 7 & - & - & 114 & 121 \\
\hline ALAGOAS & - & - & - & 51 & 51 \\
\hline AMAZONAS & - & - & - & 98 & 98 \\
\hline$B A H \mid A$ & 80 & - & - & 170 & 250 \\
\hline CEARA & 8 & - & - & 19 & 27 \\
\hline D. FEDERAL & - & - & - & 83 & 83 \\
\hline ESPIRITO SANTO & 29 & - & - & - & 29 \\
\hline GOIAS & 12.402 & 357 & 270 & 13.226 & 26.255 \\
\hline MARANHĀO & 172 & - & - & 161 & 333 \\
\hline MATO GROSSO & 5.384 & 768 & - & 4.819 & 10.971 \\
\hline MATO GROSSO SUL & 54.872 & 5.571 & 3.441 & 31.361 & 95.245 \\
\hline MINAS GERAIS & 15.740 & 272 & 440 & 9.900 & 26.352 \\
\hline PARA & 218 & - & 40 & 522 & 780 \\
\hline PARAIBA & - & - & - & 8 & 8 \\
\hline PARANÁ & 6.660 & 1.538 & 3.742 & 2.596 & 14.536 \\
\hline PERNAMBUCO & 10 & - & - & 157 & 167 \\
\hline PIAUT & - & - & - & 1 & 1 \\
\hline RIO DE JANEIRO & 330 & - & 146 & 452 & 928 \\
\hline RIO GRANDE DO NORTE & - & - & - & 25 & 25 \\
\hline RIO GRANDO DO SUL & 26 & - & 14 & 53 & 93 \\
\hline RONDONIA & 1.880 & 6 & - & 1.378 & 3.264 \\
\hline RORAAMA & 6 & - & - & 2 & 8 \\
\hline SANTA CATARINA & 16 & - & 7.988 & 81 & 8.085 \\
\hline TOTAL & 97.840 & 8.512 & 16.081 & 65.277 & 187.710 \\
\hline
\end{tabular}

Fonte: SÃO PAULo, 1984 (Serviço de Defesa Sanitäria Animal) 
2.1.2. Preços a nivel de atacado

Esses preços foram obtidos junto ao IEA; eles são coletados diariamente em diversos municípios do Estado de são paulo, junto aos atacadistas (frigorificos) mais influentes na determinação do preço em sua região, levantando- se um preço mínimo e um mäximo. Esses dados são confrontados com informaçōes fornecidas pelos equipamentos varejistas a respeito do preço pago junto aos atacadistas. Na média fi nal diária do atacado são utilizados os dois tipos de informação. Foram determinadas médias mensais mínimas e mäximas, atravès de média aritmética simples e finalmente uma média mensal final, obtida de uma média aritmética simples entre os valores mínimo e mäximo do mès.

$$
\text { Baseando-se em trabalho de CANTO (1986) as duas }
$$

sëries de preços disponíveis a nivel de atacado - preços do tra seiro e preços do dianteiro - foram utilizadas para compor uma sērie ünica, utilizando-se os fatores de ponderação 63,0\% e 37,0\%, para o traseiro e dianteiro, respectivamente. 
os preços de carne bovina a nivel de varejo foram fornecidos pela Divisão de Levantamentos Estatísticos do IEA.

o IEA realiza levantamento de preços de produ tos alimentícios no mercado varejista da cidade de são paulo desde maio de 1970. Esse levantamento originou sēries de prẹ ços, disponiveis em sua Central de Dados, cuja publicação de forma sistemática iniciou-se em abril de 1972 , com retrospec to atë abril de 1971 , na publicação "Informações Econōmicas", do pröprio Instituto.

A metodologia utilizada na obtenção dessas sé ries de preços, descrita a seguir, foi extraída dos trabaIhos de JUNQUEIRA \& CANTO (1971), UENO (1976), PECEGUINI (1979), SUEYOSHI et alii (1985) e SANTIAGO etalii(1988).

A coleta de preços a nível de varejo é baseada em uma amostra estratificada segundo os principais equipa mentos varejistas da Capital, ou seja, feiras-livres, supermercados, empörios, quitandas e açougues. No caso da carne bovina, a amostra è composta por 41 açougues e 99 supermerca dos, perfazendo um total de 140 estabelecimentos e abrangendo 33 subdistritos da capital, agrupados em cinco zonas de coleta e rateados entre cinco entrevistadores. A "checagem" dos dados e reposição dos estabelecimentos fechados são dele gados a um sexto elemento da equipe de auxiliares externos. 
o levantamento foi estruturado de forma que cada local seja visitado uma vez por mès; a coleta è realiza da de acordo com um cronograma diärio de visitas, confeccionado no final de cada mês para ser executado no mês seguinte. Os questionários utilizados são específicos para cada tipo de equipamento, com os produtos devidamente codificados. Rotineiramente, realiza-se controle de qualidade dos preços, com a eliminação de erros de preenchimento de questionärio, de digitação e de preços extremados.

Em função da pröpria característica de venda da carne bovina, antes de ser calculada a mëdia ponderadapor equipamento é necessária a aplicação de uma metodologia espe cifica. São coletados, nos açougues e supermercados, os pre ços mëdios mensais de diferentes tipos de corte, agregados pelo fator rendimento da carcaça ( 2 quartos de dianteiro e traseiro) em carnes, $156 \mathrm{~kg}$, ou $68,0 \%$ da carcaça no !'açougue", ou ainda rendimento de $34,0 \%$ em carnes considerando-se $460 \mathrm{~kg}$ como peso médio do boi vivo. os fatores de rendimento utilizados nas sēries de preços de carne bovina são: $14 \mathrm{~kg}$ para contra-filë; 4 kg para filë-mignon; 12 kg para alcatra; $16 \mathrm{~kg}$ para coxão mole; $17 \mathrm{~kg}$ para coxão duro; $10 \mathrm{~kg}$ para patinho; 5 kg para lagarto; 4 kg para músculo; 4 kg para capa de filé e $70 \mathrm{~kg}$ para carne de segunda.

os fatores de ponderação utilizados de maio de 1970 a setembro de 1973 são baseados em pesquisa realizä da pelo IEA em 1967, onde foram registrados os locais em que 
as famílias paulistanas se abasteciam em gēneros

alimenticios.

Posteriormente, com as mudanças nos häbitos de compra verificadas através das pesquisas de orçamentos Fä miliares (POF) realizadas pelo INSTITUTO DE PESQUISAS ECONÔMICAS nOS períodos de 1971772 e 1981/82, os fatores de ponderaçāo foram ajustados. No período de outubro de 1973 a maio de 1985 , os fatores de ponderação foram 76 para açougue e 24 para supermercado e baseiam-se na POF 1971/72. A partir de junho de 1985 esses fatores passam a ser 77 para açougue e 23 para supermercado, com base na POF de $1981 / 82$.

Para atingir alguns dos objetivos a que essa pesquisa se propōe, os cortes de carne bovina a nível de varejo foram separados de forma a permitir também a obtenção de um preço médio para carne de primeira e outro para carne de segunda, em $c z \$ / \mathrm{kg}$. Apesar dos dados estarem disponíveis a partir de maio de 1970, eles sào utilizados a partir de ją neiro de 1971, de modo a compatibilizar as sēries de preço no varejo com aquelas disponíveis nos demais níveis de merca do. Dessa forma, a pesquisa utilizou-se de trés sēries de preços médios mensais de carne bovina a nível de varejo, em $c z \$ / k g:$ preço médio mensal de carne de primeira, preço mëdio mensal de carne de segunda, e preço médio mensal final do va rejo, ponderados por equipamento. 
2.2. Aspectos Teöricos e Modelo Económico

Na literatura verifica-se que a estrutura de comercialização da carne bovina tem sido bastante investigada ao longo dos anos, possibilitando amplo conhecimento das características dos canais de comercialização. No entanto, - processo através do qual ocorrem as variações de preços por esses canais atē atingir o consumidor final não é conhecido de forma adequada. Torna-se, então, dificil a escolha de um modelo teörico relativo a transmissão de preços que possibilite a determinação do sentido de causalidade de preços entre os níveis de mercado (ver BARROS, 1988).

Algumas anälises de preços e margens de comercialização de produtos agrícolas basearam-se num modelo de equilíbrio estätico desenvolvido por GARDNER (1975), onde se supõe que a comercialização seja realizada sob regime de concorréncia perfeita, havendo um equilíbrio instantāneo de oferta e procura, nos niveis de produtor, atacado e varejo.

o modelo proposto por GARDNER (1975) admite que sob condições competitivas, conforme o tipo de evento e consequente efeito sobre a demanda primäria (do consumidor), a oferta primária (do produtor) ou a oferta de insumos de comercialização, os preços a diferentes níveis de mercado po dem mover-se numa mesma direção ou em direções diferentes. A utilização desse modelo apresenta algumas limitações em re- 
fletir de maneira realista o verdadeirocomportamento dos mer cados agrícolas em determinadas situaçōes. Porém, sua utili- zação visa associar os efeitos de choques da oferta e da demanda sobre os preços e margens de comercialização a um de terminado sentido de causalidade entre os preços.

Outros estudos empregaram um modelo de desequilíbrio proposto por HEIN (1980), o qual considera os aspectos dinámicos dos ajustamentos de preços.

O modelo de desequilibrio admite que no inter valo entre dois períodos e com base em resultados observados em períodos anteriores os vendedores decidem e anunciam mar gens (MC) e preços (P) a serem cobrados. Conhecendo os valo res de MC e $P$ os compradores decidem quanto comprar de bens e serviços; no decorrer do período de tempo, os compradores e vendedores têm os seus planos ajustados aos preços e margens anunciados; no final do período os vendedores reavaliam os resultados alcançados, os quais podem envolver excesso de oferta ou de procura e logo, desequilíbrio, e elaboram novos planos para o período seguinte, e assim por diante (TEIXE)$R A, \quad 1982)$.

Alguns trabalhos atribuem a relaçāo causal dos preços de compra para os preços de venda nos mercados agrí- 
colas à prätica de uma politica de "markup"l sobre os custos diretos em mercados menos competitivos (TEIXEIRA, 1982). No entanto, a ausência de competição é apenas suficiente para tal sentido de causalidade pois segundo BARROS (1987), esse tipo de causalidade pode ser verificado sob competição, na medida em que fatores do lado da oferta se alteram enquanto que os relacionados com a demanda permanecem constantes. Alëm disso, deve-se enfatizar que a prätica de "markup" não se restringe apenas aos setores não competitivos. Em outras palavras, a prática de "markup" è uma estratégia compatível com um mercado concorrencial (HEIN, 1980;BARROS,1988).

E importante enfatizar que os diferentes niveis de acesso à informação pelos setores do mercado em anälise podem influir na determinação do sentido de causalidade entre os respectivos preços e consequentemente no modelo a ser utilizado. Subtende-se que os segmentos mais bem informa dos, ou que detenham outras formas de poder de mercado, possam anteceder os demais em termos de iniciativa de ajuste de preços.

1 "markup" : em termos absolutos ele não difere da margem de comercialização; em termos relativos, no entanto, ele refere-se sempre à margem absoluta como proporção do preço de compra em cada nível de mercado (BARROS, 1987, p.39). 
No presente trabalho, parte-se do pressuposto que as variaçōes de preços possam iniciar-se em qualquer nível de mercado, admitindo-se, àinda, que o sentido de causalidade entre os preços possa variar de acordo com a importān cia relativa de fatores ligados à oferta e demanda do produto.

$$
\text { GARDNER(1975), conforme discute-se em BARROS(1987), }
$$

considera um modelo analitico com uma indústria competitiva de comercialização de alimentos, usando dois fatores de produção - matèria-prima agrícola (a) e insumos de mercado (b), para produçäo do bem final vendido no varejo $(x)$. Através desse modelo ele examina as consequēncias do equilibrio competitivo no mercado do produto agrícola e no mercado de serviços de comercializaçāo sobre a relaçäo entre os preços de alimentos no varejo e na fazenda.

$$
\text { o modelo de GARDNER (1975). é constituido de }
$$

seis equaçōes para determinação dos preços e quantidades a nivel de varejo e produtor:

$$
\begin{aligned}
& x=f(a, b) \\
& x=D(P x, N) \\
& P t=P x . f b, \quad \frac{\delta x}{\delta b}=f b
\end{aligned}
$$


$P a=P x . f a, \quad \frac{\delta x}{\delta a}=f a$

$P b=g(b, T)$

- $p a=h(a, w)$

onde:

(a) representa a função de produção da indüstria, a qual Gardner pressupōe possuir retornos constantes à Escala;

(b) representa a função de demanda de $x$, sendo Px o preço de varejo e $N$ uma variävel exögena (renda per capita, por exemplo);

(c) e (d) representam as igualdades do preço do fator ao seu valor do produto marginal, condiçäo necessária à maximização do lucro das firmas;

(e) e (f) representam as ofertas dos dois insumos de comercialização considerados, sendo $T$ e w variáveis exögenas (por exemplo, imposto fixo e clima, respectivamente).

o autor pressupōe que a elasticidade de substituição entre insumos de comercialização e de matēria-prima agrícola é constante. Atravès da combinação e diferenciação total das equações, ele determinou a elasticidade da razāo de preços a nível de varejo e produtor (Px/Pa) em relação às variäveis exógenas relacicnadas à demanda do produto a nivel de varejo, à oferta dos insumos de comercialização e à oferta de matéria-prima agrícola. 
As principais conclusōes do estudo de GARDNER (1975) para os mercados competitivos agrícolas säo:

- variaçóes na demanda final de um produto agrícola tendem a causar variaçöes de sinal conträrio nas mar gens percentuais de comercializaçä;

- variaçōes na oferta de matēria-prima agríco la produzem efeito de mesmo sentido nas margens de comercializạ̧ão;

- variaçōes na oferta de insumos de comercialização tendem a produzir efeitos de sinal conträrio sobre as margens;

- em geral, a elasticidade de transmissäo de preços do produtor ao varejo é inferior à unidade, significando que os preços tendem a ser mais estáveis à medida que se passe do nível de produção para o nível de consumo.

Esses resultados permitem prever efeitos de politicas voltadas ao controle de preços nos mercados agríco las, tais como o tabelamento de preços ao consumidor e programas de politicas de preços mínimos. BARROS \& XAVIER (1979) realizaram uma avaliação dessas políticas.

A anälise gräfica para situações em que se po de ajmitir tungzes de coejicientes fixos pode ser encontrada em BARROS (1987).

Para outras formas de relaçōes de mercado inexiste modelo com igual grau de elaboração. O modelo com 
petitivo cumpre, no entanto, uma função didätica para com preensão do funcionamento da comercialização agrícola.

2.3. Processos Auto-Regressivos Vetoriais e Causalidade

A anälise a ser desenvolvida baseia-se na estimação de um modelo de auto-regressão vetorial (ver SIMS, 1972 ; SIMS, 1980 ; BESSLER, 1984 ; CHAMBERS, 1984 e BRANDÃO, 1985), constituído das variáveis preços a nível de produtor $(P p)$, Preço no atacado $(P a)$ e Preço no varejo (Pv). o método adotado permite a anälise de diversos aspectos do problema, apresentando algumas vantagens sobre outros modelos, tais como possibilitar a añi ise de causalidade entre as très variäveis em estudo numa anälise única e a obtenção de efeitos e duração de choques em cada uma das variäveis consideradas sobre as demais.

o procedimento adotado consiste em estimar ns parämetros de uma representação auto-regressiva de um pro cesso estocästico vetorial e utilizar uma representação de médias móveis para estudar os mecanismos de propagação de choques, através de obtenção dos coeficientes da representação de médias möveis e decomposição da variância dos erros de previsão K-períodos adiante em percentagens a serem atribuídas aos choques em cada um dos processos componentes do mode 10. 
E de conhecimento geral que a produçäo de car ne bovina está sujeita a variação cíclica plurianual e a variações estacionais dentro de um mesmo ano, resultantes da - sazonalidade da produção forrageira. Portanto, em cada auto- regressão vetorial a ser realizada, serão incluídas onze variáveis binárias, para controle dos efeitos sazonais, Sit $\left(\operatorname{com} i=1, \ldots, 11\right.$, sendo $s_{i t}=1$ para o més de ordem $i+1$ e $S_{i t}=0$ para os demais meses) e uma variável tendência (T). Segundo ADABO (1980), o movimento de tendência pode flutuar, porém sempre em torno de uma tendência histörica ou secular, que tem demonstrado ser crescente, no longo prazo, para os preços reais do boi gordo. Para controle da variação cíclica plurianual serão utilizados logaritmos neperianos de cada variàvel e anälises harmônicas das séries de dados originais, explicados oportunamente.

Para processamento dos dados - realização das auto-regressões vetoriais e testes de causalidade - serà ut lizado o pacote estatístico Regression Analysis for Time Series (RATS), desenvolvido por DOAN E LITTERMAN (1981).

2.3.1. Processos auto-regressivos vetoriais

Um processo (ou modelo) estocästico (real ou complexo), $\{x(t, w), t \varepsilon T, w \varepsilon \Omega\}$ è uma sequência (no tempo) de variáveis aleatórias (com valores reais ou comple- 
xos $), X(t, w)$, definidos num mesmo espaço de probabilidades $(\Omega, A, P)$ (PINO, 1980 e MORETTIN \& TOLOI, 1981).

Quando há um conjunto de observaçōes geradas sequencialmente no tempo tem-se uma série temporal \{zt, $t \varepsilon$ T) Uma característica fundamental das sëries temporais é que suas observaçōes geralmente näo säo independentes e sim serialmente correlacionadas.

Se os valores futuros de uma sērie temporal puderem ser determinados por alguma funçāo matemática ela é denominada deterministica. Caso seus valores futuros puderem ser determinados apenas por uma distribuição de probabilidade ela é denominada estatística ou näo-deterministica, podendo ser tomada como uma realização ou trajetória particu lar de um processo estocástico. Istoé, num processo estocástico, fixando-se $t, x(t, w)$ é uma variävel aleatöria e fi xando-se $w, x(t, w)$ è uma sërie temporal.

o processo estocàstico é estacionário se suas propriedades näo variarem ao longo do tempo, as caracteristi cas de $Z(t+\eta)$, para todo $T$, são as mesmas de $Z(t)$, isto $\bar{e}$, se $z t$ for um processo estacionärio, $p(z t)$ para $t=t_{0} \bar{e} i d e ̂ n$ tica a $p(Z t)$ para $t=t_{0}+K$; nesse caso o processo permanece numa espécie de equilibrio estatistico ao redor de um nivel médio constante. Quando a estrutura de probabilidade do processo não depende da origem do tempo mas de diferenças no tempo, a distribuição conjunta de $N$ observaçöes $Z t(1)$, 
$Z t_{(2)}, \ldots, Z t_{(N)}$ é a mesma de outroconjunto $Z t(1+I)$, $2 t(2+m), \ldots, 2 t(N+m)$ afastadas do tempo ? unidades, ele é considerado estritamente estacionärio:

$P\left(Z t_{(1+\tau)} \varepsilon s_{1}, \ldots, Z t_{(N+?)} \varepsilon s_{N}\right)=P\left(Z t_{(1)} \varepsilon s_{1}, \ldots, Z t_{(N)}\right.$

$\left.\varepsilon S_{N}\right)$, para todo $t_{1}<\ldots<t_{N}$, $T E T$ e eventos reais $S_{1}$, .... $S_{N}$. Caso os momentos de ordem até m dependam apenas de diferenças no tempo, o processo é denominado fracamente estä cionärio lou estacionário de segunda ordem ou em sentido amp lo)

Uma sequéncia $a_{t}, t \in T$ de variäveis aleatörias independentes e identicamente distribuidas, usualmente com distribuição normal, de média zero e variância constante é denominada ruído branco e as variáveis são denominadas choques aleatörios (PINO, 1980).

Para maiores detalhes sobre processos auto-re gressivos, ver $80 X \&$ JENKINS $(1976)$, PINO (1980), MORETTIN $\varepsilon$ TOLOI (1981) e TIAO \& BOX (1981).

Representando uma série $z$ t por uma soma de $P$ observaçōes anteriores da série mais um termo aleatörio (cho que ou inovaçãol obtemos um processo auto-regressivo de ordem $p$, tal como:

$z t=\phi_{1} z_{(t-1)}+\phi_{2} z_{(t-2)}+\cdots+\phi_{p} z_{(t-p)}+a_{t}$

Se definirmos o operador auto-regressivo estä cionärio de ordem p

$\phi(B)=1-\phi_{1} B-\phi_{2} B^{2}-\ldots-\phi_{P} B^{P}$ 
entäo pode-se escrever

$\phi(B) z_{t}=a_{t}$

que tambëm pode ser escrito

$Z_{t}=\omega^{-1}(B) a_{t}$

Como $\phi(8)$ é finito, não hà restriçōes sobre os parámetros para assegurar invertibilidace de um processo auto-regressivo (PINO, $1980, P .36)$. O processo $Z_{t}$ pode, en tão, ser invertido, obtendo-se $z_{t}$ como uma soma ponderada de valores presentes e passados de ${ }{ }_{t}$ :

$z_{t}=a_{t}+\epsilon_{1} a_{(t-1)}+\epsilon_{2} a_{(t-2)}+\ldots+\theta_{p} a(t-p)$

$z_{t}=a_{t}+\sum_{p=1}^{\infty} \epsilon_{p} a(t-p)$

considerando $x_{t}$ um processo estocástico estacionärio com $n$ componentes $\left(x_{t}\right.$ é um vetor $\left.n \times 1\right)$, representa tivo de um processo auto-regressivo estacionärio de média nu la, temos:

$x_{t}=B_{1} X_{(t-1)}+B_{2} X_{(t-2)}+\ldots+e_{t}$

onde $e_{t} \ddot{e} u m$ vetor de $n$ elementos e $B_{k}$ sãomatrizes $n \times n$. Como um processo estocástico estacionário tém uma representa ção de médias möveis (Teorema da Representação de Wold, ver SARGENT (1979)), $x_{t}$ pode ser representado por um sistema de mèdias móveis:

$x_{t}=e_{t}+A_{1} e_{t-1}+A_{2} e_{t-2}+\cdots$

onde $e_{t}$ é un processo estocástico com mëdia zero, matriz de 
variāncia-covariància finita (E) e não auto-correlacionado (e $e_{t}$ è um ruido branco).

Definindo-se L um operador de defasagens, tal

que :

$L^{j} z_{t}=z_{(t-j)}$

sendo $j$ inteiroe $A(L)$ um polinómio no operador $L$, dado por: $A(L)=A_{0}+A_{1} L+A_{2} L^{2}+\ldots$

onde $A(L)$ é chamada matriz de respostas a impulsos, sendo $A_{j}$ matrizes $n \times n$ para todo $j$ e $A_{0}=1$.

Podemos reescrever (4) como:

$X_{t}=A(L) e_{t}$

Sob condiçöes de invertibilidade, e sendo $B(L)$ também um operador de defasagem, com coeficiente $B_{j}$, te mos:

$B(L) X_{t}=e_{t}$

sendo $B(L)=A^{-1}(L)$

Nessa condiçāo, os polinômios $A(L)$ e $B(L)$ satisfazem a relaçāo $A(L) . B(L)=1$; então:

$B(L)=B_{0}-B_{1} L-B_{2} L^{2}+\ldots$

onde $B_{0}=1$.

Podemos representar (5) na forma:

$X_{t}=B_{1} X_{(t-1)}+B_{2} X_{(t-2)}+\ldots+B_{m} X_{(t-m)}+e_{t}$ 
Em (6) e é o erro de previsão de um período,

definido por:

$e_{t}=x_{t}-E\left|x_{t} / x_{(t-1)}, x_{(t-2)}, \ldots\right|$

o erro de previsão refere-se, algumas vezes, a inovação no processo $x_{t}$. Os erros de previsão de k-periodos podem ser definidos por:

$x_{(t+K)}-E\left|x_{(t+K)} / x_{t}, x_{(t-1)}, \ldots\right|$

$\operatorname{com} k=1,2,3, \ldots$

2.3.2. Teste da razão de verossimilhança

Para a realização de testes de causalidade, de ve-se estabelecer primeiramente o nümero de defasagens a ser. considerado, pois observa-se que (5) contém um nümero infini to de parametros. Normalmente compara-se duas formas alter nativas do modelo: um sistema irrestrito (com maior nümero de defasagens) contra um sistema restrito (com menor nümero de defasagens). Rejeitando-se a hipótese de que as defasagens de ordem $m+1, m+2, \ldots$, M aumentam o poder explicativo da regressão, considera-se m comp o nümero adequado de defasagens.

SIMS (1980) sugere o seguinte teste de razão de verossimilhança, o qual é utilizado nesta anälise: $R=(T-K)(\log |D r|-\log |D u|)$ 
onde $\mid$ Dr| e $\mid$ Du| são os determinantes da matriz da soma de produtos e produtos cruzados residuais (matrizes da estimati va de variáncia e covariáncia dos modelos) para os modelos, respectivamente, restritos e sem restrição. T é o tamanho da amostra e $k$ o número de coeficientes estimados no modelo sem restrição. R é distribuído assintoticamente como $x^{2}$ com $(m+E)$ graus de liberdade, onde $\theta$ è o nümero de restriçōes em cada equação.

Na realizaçāo do teste são ajustadas duas auto-regressōes vetoriais, por minimos quadrados ordinários aplicados a cada equaçāo individualmente, as quais terāo coeficientes estimados consistentemente por apresentarem em seu segundo membro as mesmas variàveis (BESSLER, 1984):

$x_{t}=\sum_{j=1}^{n+\theta} E_{j} x_{t-j}+e_{t} \quad$ e $\quad x_{t}=\sum_{j=1}^{n} B_{j} x_{t-j}+e_{t}$

com

$D u=\sum_{t=n+\theta+1}^{T}\left(x_{t}-\sum_{j=1}^{n+\theta} \bar{B}_{j} x_{t-j}\right)\left(x_{t}-\sum_{j=1}^{n+\theta} \bar{B}_{j} x_{t-j}\right)^{\prime}$

$D r=\sum_{t=n+1}^{T}\left(x_{t}-\sum_{j=1}^{n} \bar{B}_{j} x_{t-j}\right)\left(x_{t}-\sum_{j=1}^{n} \bar{B}_{j} x_{t-j}\right)^{\prime}$.

Determinando-se o nümero de defasagens a ser utilizado realiza-se a anälise de caysalidade. Tal anälise pode ser feita pelo uso do teste f para grupo de variáveis ou pela razão de verossimilhança. Esse trabalho fará uso do teste $F$. 
2.3.3. Simulaçāo de respostas a choques aleatörios

Após a determinação do nümero de defasagens, (5), que pode ser escrita na forma (6):

$X_{t}=e_{t}+B_{1} X_{(t-1)}+B_{2} X_{(t-2)}+\ldots+B_{m} X_{(t-m)}$

pode ser estimada por minimos quadrados ordinärios.

De (4'), reescrita na forma (4):

$x_{t}=e_{t}+A_{1} e_{(t-1)}+A_{2} e_{(t-2)}+\ldots$

verificamos que:

$A_{k}=\left[\begin{array}{ccc}a_{1}^{k} & \ldots & a_{1}^{k} \\ a_{n} & \ldots & a_{n n}^{k}\end{array}\right] ; \quad e_{t}=\left[\begin{array}{c}e_{1}(t) \\ e_{2(t)} \\ \vdots \\ e_{n(t)}\end{array}\right] ; \quad x_{t}=\left[\begin{array}{c}x_{1}(t) \\ x_{2}(t) \\ \vdots \\ x_{n}(t)\end{array}\right]$

os choques decorrem de variações unitärias no vetor $e_{t}$ e conhecendo-se (4) pode-se descrever o comportamento dinámico das variáveis em resposta a choques sobre qual quer componente do sistema.

Assim, a i-ésima coluna de $A_{k}$ mede o efeito de um choque unitärio no i-ésimo componente do vetor de inovaçöes no periodo $(t-k)$ sobre $x_{n}$ no periodo $t$.

Tratando-se de um modelo auto-regressivo veto rial, em geral, a matriz de variáncia-covariância de e(t) 
näo é uma matriz diagonal, significando que os choques $e_{1}(t)$, $e_{2(t)}, \ldots, e_{n}(t)$, tendem a ocorrer simultaneamente com uma probabilidade diferente de zero, isto é, podem ser contemporaneamente correlacionados, sendo o choque em ek $(t-n)$ acompa nhado por alteraçōes contemporáneas nos demais $e_{i}(t-n)$. Por tanto, para que se possa examinar efeitos de choque em uma variāvel sobre o resto do sistema pode-se utilizar um procedimento que diagonalize a matriz de variāncia-covariància (E). O procedimento mais comum, e que será utilizado nesse trabalho, è a decomposição de Cholesky.

Utilizando-se a decomposição de cholesky, se a matriz $\Sigma$ for näo-singular, existe uma matrizH, triangular inferior e não-singular, tal que:

$\Sigma=H \cdot H^{\prime}$

onde $H^{\prime}$ é a matriz transposta de H. Isto é:

$H^{-1} \cdot \Sigma\left(H^{\prime}\right)^{-1}=1$

$$
\text { Definindo-se } n(t)=H^{-1} e_{(t)} \text {, tem-se: }
$$

$E\left|n_{t} n_{t^{\prime}}\right|=E\left(H^{-1} e_{t} e^{\prime}{ }_{t}\left(H^{-1}\right)^{\prime}\right)=H^{-1} E\left(e_{t} e^{\prime}{ }_{t}\right)\left(H^{-1}\right)^{\prime}=$

$$
=H^{-1} \Sigma\left(H^{\prime}\right)^{-1}=1
$$

Se $D=H^{-1}$ e multiplicarmos (5) por $D$, obtemos:

$D \cdot B(L) X_{t}=D \cdot e_{t}=H^{-1} \cdot e_{t}$

entäo:

$D . B(L) X_{t}=n_{t}$ 
Se $H(L)=D B(L)$, obtemos:

$H(L) \cdot x_{t}=n_{t}$

a qual pode ser representada por médias móveis,

$x_{t}=G(L) n_{t}$

onde $G(L)=A(L)$. $H$ e $n_{t} \dot{e} u m$ ruido branco.

Como consequéncia do procedimento utilizado, G mede o impacto de um choque unitärio em $n_{i}(t-j)$, igual a um desvio padräo de $e_{t}$, sobre $x_{t}$.

Isto é, se $n_{i}(t-j)$ é o $i-\dot{e} s i m o$ componente do vetor de inovações ortogonalizadas, um choque unitärio em $n_{i}(t-j) \dot{e} \circ$ vetor $n_{t}:$

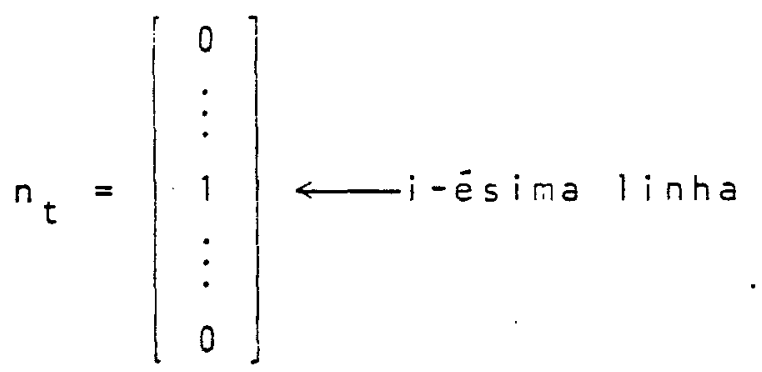

Então, se $n_{i}(t)=1, n_{j}(t)=0, i \neq j$ e ${ }^{n}(t+1)=n(t+2)=\cdots=n(t+k)=0$, o choque sobre $x$ durante os periodos $t, t+1, \ldots, t+k$ é descrito pelos respectivoscoe ficientes de $(10)\left(G_{0}, G_{1}, G_{k}\right)$.

Uma das principais vantagens das inovaçöes or togonalizadas sobre as demais $\bar{e}$ a de serem näo-correlacionadas. No entanto, há uma decomposição diferente para cada or denação das variäveis, sendo que a direção do efeito captado 
decorre da seleção arbiträria da ordem das variáveis no vetor analisado. Logo, quanto menor a covariáncia contemporanea (menor correlaçäo entre os residuos), menor é a importān cia da ordem selecionada. Inovaçōes na primeira variável da ordem afetam as demais contemporaneamente, mas essa variável não é afetada por nenhuma das outras. A segunda variävel deve impactar as posteriores, mas não será impactada contemporanea mente por inovações em nenhuma delas.

Embora possa näo haver causalidade entre duas variáveis, poderá haver efeito de um choque em uma delas sobre a outra, devido a covariància entre as variàveis.

2.3.4. Decomposição dos.erros de previsão de k-perío dos

Partindo-se da equaçäo (7), para um período

teremos:

$e_{t}=x_{t}-E\left|x_{t} / x_{(t-1)}\right|$

e

$E\left|e_{t} \cdot e_{t^{\prime}}\right|=\Sigma=H \cdot H^{\prime}$

onde a diagonal principal è uma soma de quadrados.

Para um modelo de duas variáveis teremos: 
$H=\left[\begin{array}{cc}h_{11} & 0 \\ h_{21} & h_{22}\end{array}\right] ; \quad H \cdot H^{\prime}=\left[\begin{array}{ccc}h_{11}^{2} & h_{11} \cdot h_{21} \\ h_{1} \cdot h_{21} & h_{21}^{2} \cdot h_{22}^{2}\end{array}\right]$

$e \quad e_{t^{\prime}}=\left|e_{t}, e_{t_{t}}\right|^{\prime}$

Observa-se que $100 \%$ da variáncia do erro de previsão de um periodo em $x_{1}$ se deve aos chocues sobre $x_{1}$ e que $\left(h_{21}^{2} / h_{21}^{2}+h_{22}^{2}\right)$. 100\% da variancia do errode previsäo em $x_{2}$ se deve a choques em $x_{1}$.

obtida de:

A variáncia do erro de previsão para k-periodos é $X_{(t+k)}=G_{0} n(t+k)+G_{1} n(t+k-1)+\ldots+G_{k-1} n(t+1)+G_{k} n(t)+G_{k+1} n(t-1)+\ldots$

logo:

$x(t+k)-E\left|x(t+k) / x_{t}, x(t-1) \ldots\right|=\sum_{j=0}^{k-1} G_{j} n(t+k-j)$

e a variància è :

$\sum_{j=0}^{K-1} A_{j} \quad \sum A_{j}^{\prime}=\sum_{j=0}^{K-1}\left(A_{j} H\right)\left(A_{j} H\right)^{\prime}$

A diagonal principal de cada uma das matrizes desta soma é uma soma de quadrados, podendo-se atribuir à va riancia do erro de previsão de cada periodo a parcela devida à própria variável e as parcelas devidas às demeis (BRANDÃo, $1985)$ 
A anälise de causalidade a ser efetuada baseia-se no conceito de causalidade a - la Granger - sims, ten do sido desenvolvido inicialmente por GRANGER (1969) e implementado por SIMS (1972) (verPIERCE \& HAUGH, 1977; BISHOP, 1979; FEIGE \& PEARCE, 1979 e STOKES E NEUBURGER, 1979).

De acordo com GRANGER(1969), sendo $x_{t}$ umprocesso estocástico estacionário, $\bar{U}_{(t-1)}$ o conjunto universo de informaçōes acumuladas até omomento $(t-1)$, e $P_{t}\left(x_{t} / \bar{U}_{(t-1)}\right)$ o preditor ötimo e não-viesado de mínimos quadrados de $x_{t}$, res trito ao universo de informaçōes $\bar{U}(t-1)$, haverá um erro de previsão $\varepsilon_{t}\left(x_{t} / \bar{U}_{t-1}\right)=x_{t}-p\left(x_{t} / \bar{U}_{(t-1)}\right)$ com variäncia $\sigma^{2}\left(x_{t} / \bar{U}(t-1)\right)$. Então, se:

$\sigma^{2}\left(X_{t} / \bar{U}_{(t-1)}\right)<\sigma^{2}\left(X_{t} / \bar{U}_{(t-1)}-\bar{Y}_{(t-1)}\right)$

diz-se que $Y_{t}$ está causando $X_{t}$, pois há maior capacidade de previsão de $x_{t}$ usando toda a informação disponivel em $(t-1)$ do que quando se excetua aquela referente à sērie y, ou seja, $\bar{U}_{(t-1)}-\bar{Y}_{(t-1)}$.

\section{Quando:}

$\sigma^{2}\left(x_{t} / \bar{U}_{(t-1)}\right)<\sigma^{2}\left(x_{t} / \bar{U}_{(t-1)}-\bar{Y}_{(t-1)}\right)$

$\sigma^{2}\left(Y_{t} / \bar{U}(t-1)\right)<\sigma^{2}\left(x_{t} / \bar{U}_{(t-1)}-\bar{x}_{(t-1)}\right)$

haverä um feedback entre $X$ e $Y$. 
Caso seja possivel prever melhor $x_{t}$ usando-se tambëm o valor corrente de $Y_{t} e$ não apenas $\bar{Y}_{(t-1)}$, ou seja: $\sigma^{2}\left(x_{t} / \bar{U}_{(t-1)}, Y_{t}\right)<\sigma^{2}\left(x_{t} / \bar{U}_{(t-1)}\right)$, a causalidade $\bar{e}$ dita instantānea.

o seguinte teste de causalidade conhecido por "Teste Direto de Granger", pode ser obtido limitando-se ouniverso de informaçöes às séries $X$ e $Y$, estacionárias e esto càsticas:

$x_{t}=\sum_{j=1}^{\infty} a_{j} x_{t-j}+\sum_{j=1}^{\infty} b_{j} Y_{t-j}+\varepsilon_{j}$

e

$Y_{t}=\sum_{j=1}^{\infty} c_{j} X_{t-j}+\sum_{j=1}^{\infty} d_{j} Y_{t-j}+n_{t}$

$E\left(\varepsilon_{t} \in s\right)=0=E\left(n \neq n_{s}\right), s \neq t \quad$ e $E\left(\varepsilon_{t} n_{s}\right)=0$,

para tocio t, $s$.

As equaçōes (a) e (b) säo, entäo, estimadas por mínimos quadrados ordinärios. Diz-se que Y causa $X$ se os $b_{j ' s}$ forem em conjunto estatisticamente diferentes de zero, e que $X$ causa $Y$ se os $c_{j}$ 's forem em conjunto estatisticamete diferentes de zero. Se ocorrem os dois eventos hä feedback entre $X e Y$. Caso esses coeficientes sejam todos estatistica mente iguais a zero não há relação de causalidade entre as. variäveis em questão (ver SIMS, 1972; SARGENT, 1979 e MARQUES, 1983). 
SIMS (1972) propõe que a definição de causali dade segundo GRANGER (1969) seja vista da seguinte forma: "Se e somente se o sentido de causalidade for unicamente dos valores presentes e passados de uma série de variäveis exógenas para uma dada variàvel endógena, então numa regressão da variävel endógena, com valores passados, correntes e futu ros das variáveis exógenas, os valores futuros das variáveis exógenas deveriam ter coeficientes nulos"(SIMS, 1972 , p.541).

o teste de causalidade proposto porSIMS(1972), combase nos conceitos de GRANGER(1969), consiste em estimar a equação (c) e utilizar a estatística f para analisar a signifi cância estatistica do conjunto de coeficientes futuros. $X_{t}=\sum_{j-\infty}^{\infty} v_{j} Y(t-j)+\varepsilon_{t}$

$$
\text { Diz-se que } X \text { näo causa } Y \text { se os } v_{j ' s} \text { forem em }
$$
conjunto significativamente iguais a zero, para j $<0$.

Da equação (b) temos que $X$ não causa $Y$ se os coeficientes $c_{j}$ forem todos iguais a zero. SIMS prova que os cj's seräo nulos apenas se na equação (c) os vj's forem nulos, para $j<0$. Se $x$ näo causa $Y$ no sentido de GRANGER, $X$ pode ser expresso apenas como funçäo dos valores presentes e passados de $Y$, com um resíduo ortogonal a $Y$ em todos os lags, portanto, o fato de $X$ não causar Y é equivalente ao conceito de exogeneidade econométrica estrita de Y em rélaç̃o a $X$. 
SIMS(1972) e BISHOP(1979) sugeren anälise de causalidade através de estimativas de equaçöes com oi to variāveis defasadas, uma corrente e quatro futuras, procedimen to adotado por diversos autores, como TEIXEIRA(1982), BURNQUIST(1986), BARROS \& BURNQUIST (1987), BARROS \& MARTINES FO $(1987)$ e MARTINES F $:(1988)$.

Nesse trabalho, pretende-se analisar o sentido de causalidade entre os niveis de mercado numa anälise única, utilizando o modelo de auto-regressäovetorial. No entanto, a análise de causalidade apenas entre pares de preços (produtor $x$ varejo, produtor $x$ atacado, atacado $x$ pro dutor) tambëm será realizada, com a finalidade de comparar os resultados obtidos através das duas metodologias.

o procedimento estatistico utilizado no trabalho, para realização do teste de causalidade entre pares de variäveis, consiste em estimar equaçöes utilizando doze variäveis defasadas, doze variảveis futuras e uma variävel presente (ver AGUIAR E BARROS, 1988), a lém de variäveis binärias para controle dos efeitos de sazonalidade e uma variävel tendēncia (equaçōes completas) e equaçöes restritas (sem os valores futuros), exemplificadas a seguir para o par produtor $x$ atacado.

$$
P P_{t}=a_{0}+a_{1} P A_{t}+\sum_{i=1}^{12} a_{2 i} P A_{t+i}+\sum_{k=1}^{12} a_{3 k} P A_{t-k}+\sum_{j=1}^{11} a_{4 j} D_{j}+a_{5} T+e_{i t}
$$

$$
P A_{t}=b_{0}+b_{1} P P_{t}+\sum_{i=1}^{12} b_{2 i} P P_{t+i}+\sum_{k=1}^{12} b_{3 k} P P_{t-k}+\sum_{j=1}^{11} b_{4 j} D_{j}+b_{5} T+e_{2 t}
$$




$$
\begin{aligned}
& P P_{t}=c_{0}+c_{1} P A_{t}+{ }_{k=1}^{12} c_{2 k} P A_{t-k}+\sum_{j=1}^{11} c_{3 j} D_{j}+c_{4}{ }^{\top}+e_{3 t} \\
& P A_{t}=d_{0}+d_{1} P P_{t}+{ }_{k=1}^{12} d_{2 k} P P_{t-k}+\sum_{j=1}^{11} d_{3 j} D_{j}+d_{4}{ }^{\top}+e_{3 t}
\end{aligned}
$$

onde:

$$
\begin{aligned}
& P P=\operatorname{logaritmo~do~preço~real~a~nível~de~produtor.~} \\
& P A=\text { logaritmo do preço real a nível de atacado. } \\
& D_{j}=\text { variäveis binärias } \\
& T \quad=\text { variävel tendēncia }
\end{aligned}
$$$$
a_{0}, a_{1}, a_{2 i}, a_{3 k}, a_{4 j} \text { e } a_{5} \text { - parāmetros a serem estimados na }
$$$$
\text { equaçāo ( } 1 \text { ) }
$$$$
b_{0}, b_{1}, b_{2 i}, b_{3 k}, b_{4 j} \text { e } b_{5} \text { - parämetros a serem estimados na }
$$$$
\text { equação (11) }
$$$$
c_{0}, c_{1}, c_{2 k}, c_{3 j} \text { e } c_{4} \text { - parämetros a serem estimados na }
$$$$
\text { equaçào }(111)
$$$$
d_{0}, d_{1}, d_{2 k}, d_{3 j} \text { e } d_{4} \quad \text { - parámetros a serem estimados na }
$$$$
\text { equação (IV) }
$$$$
e_{1 t}, e_{2 t}, e_{3 t} \text { e e } 4 t \quad \text { - erros aleatórios }
$$

Na filtragem dessas equaçōes será utilizado o filtro obtido pela técnica iterativa de COCHRANE-ORCUTT (KMENTA, 1978; MARTINES FO, 1988). 
68.

Para verificação da eficäcia do filtro utilizado serão utilizados os testes de Durbin-Watson e Q-estatís tica de Box-Pierce (ver MORETTIN \& TOLOl, 1981), e pelo exame das propriedades auto-regressivas dos residuos (ut), estimando-se $\theta$ por mínimos quadrados ordinärios na equação a seguir (BISHOP, 1979): .

$$
u t=\theta(u t-1)+v t
$$

Se o coeficiente $\theta$ não for estatisticamente significativo, utilizando-se o teste t de STUDENT, o filtro foi eficaz em eliminar a autocorrelação entre os resíduos. o teste de causalidade consiste em testar as seguintes hipōteses:

$$
\begin{aligned}
& a_{21}=a_{22}=\ldots=a_{212}=0 \\
& b_{21}=b_{22}=\cdots=b_{212}=0
\end{aligned}
$$

A estatistica $F$ é realizada aplicando-se

fórmula abaixo para as equaçōes $1 / 111$ e $11 / 1 \mathrm{~V}$ (KMENTA, 1978):

$$
F=\frac{(S Q R r-S Q R u) /(q-p)}{S Q R u /(n-q)}
$$

onde:

SQRr - é a soma dos quadrados dos resíduos na regressão com restriçào.

SQRu - é a soma dos quadrados dos residuos na regressäo sem restrição. 
q - nümero de paràmetros estimados na regressāo sem restrisão.

p - nümero de parámetros estimados na regressão restrita.

n - nümero total de observações.

Caso a hipótese(11) seja rejeitada e a hipótese (1) nāo o for, haverá causalidade de PP para PA (PPAPA). Caso ocorra o contrário, haverá causalidade de pA para PP $(P A \rightarrow P P)$. Rejeitando-se as duas hipóteses haverá uma relação bicausal (PP $\rightarrow P A)$. Caso as duas hipóteses não sejam ré jeitadas há ausēncia de causalidade entre PP e PA.

A pré-filtragem das séries de variàveis é necessäria caso seja detectada autocorrelaçäo entre os resíduos. Isto é, em testes onde será usada a estatistica-F para tes tar a significancia dos coeficientes. futuros, os resíduos $\varepsilon_{t}$ da regressão (c) näo devem apresentar correlaçāo serial. Cá so contrário, as estimativas dos coeficientes vj seräo consistentes, mas os valores estimados de suas variancias seräo viesadas, geralmente para baixo, resultando em superestimati vas das estatisticas $t, R^{2}$ e $F$, comprometendo as conclusōes baseadas no teste F. Essa pré-filtragem visa transformar as séries em ruído branco.

A filtragem comumente utilizada é aquela que substitui cada variävel $x_{t}$ observada pela transformaça: $x_{t}^{*}=(1-K L)^{2} x_{t}=\left(1-2 K L+K^{2} L^{2}\right) x_{t}=x_{t}-2 K x_{t-1}+k^{2} x_{t-2}$ 
normalmente $K=0,75$ (SIMS, 1972; BISHOP, 1979).

Neste trabalho seräo testadas outras formas de filtro, com o objetivo de minimizar o problema da autocorrelação dos resíduos e os efeitos cíclico e sazonais característicos do mercado de carne bovina.

Alguns dos procedimentos de pré-filtragem a serem testados são os seguintes:

(a) Transformação de cada sērie original de preços reais - produtor $(P p)$, atacado ( $P a)$, e varejo (Pv) em seus logaritmos naturais, resultando novas sēries a serem utilizadas nas anälises;

(b) Cada sērie original Pp, Pa e Pv, será transformada por anälise harmōnica, e os resíduos obtidos nessa anälise, para cada série respectivamente, constituirão as novas variáveis a serem utilizadas;

(c) Com as novas séries de variäveis obtidas com as transformaçöes (a) e (b) e tambëm as sëries originais, serão realizadas algumas auto-regressões, procurando uma identificação prévia quanto ao nível de mercado em que se originam as variações de preços. Partindo-se dessa primeira identificação, a sërie de preços em questão serä transformada por anälise harmônica e servirá de filtro para as demais, da seguinte forma: caso haja indicação de que as oscilações de preços iniciem-se ao nível de atacado, serä estimada uma anälise harmōnica de pa, obtendo-se a série $\hat{\rho}_{a}$, 
que servirà de filtro para as sëries originais, obtendo-se as sëries Fa, Fp e Fv, correspondentes às sëries de preços filtradas para o atacado, produtor e varejo, respectivamente, e que serão utilizadas nas anälises, ou seja:

$$
\begin{aligned}
& P_{a}-\dot{\rho}_{a}=F a \\
& P p-\hat{\rho}_{a}=F P \\
& P v-\hat{f}_{a}=F v
\end{aligned}
$$

2.5. Anälise Harmônica

A anälise harmónica, ou espectral, estuda a sērie no domínio da frequēncia. Considera-se que a série tem poral admite uma representação espectral, ou seja, que ela pode ser decomposta em componentes harmónicos simples (ver Koopmans ${ }^{1}$, 1974 in PINO. et ali $i$ 1983).

Sejam $z_{t}, t=0, \pm 1, \pm 2, \ldots, \quad$ observações de uma sërie temporal. A Figura 6 a seguir representa cada harmonico por uma senöide:

KOOPMANS, L.H. The espectral analys is of time series. New York, Academic Press, 1974. 366 p. 


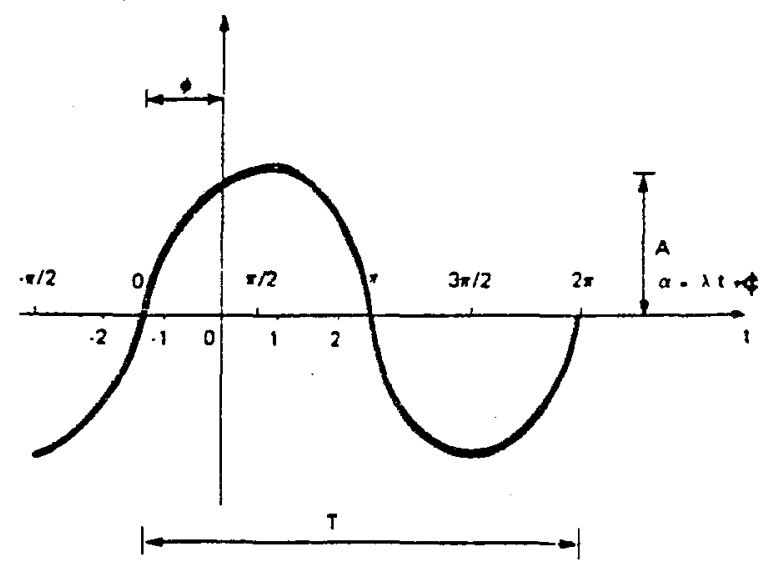

Figura 6. Gräfico de $A \operatorname{sen}\left(\lambda_{t}+t\right)$.

onde:

$T=$ periodo, ou tempo necessärio para completar un ciclo;

$f=$ frequéncia, medida em ciclos por unidade de tempo $f=1 / T$;

$\lambda=$ frequéncia angular, medida em radianos por unidade de tempo: $\lambda=2 \pi f$;

$A=a m p l i t u d e$, medida na mesma unidade que as observaçöes da série;

$$
\begin{aligned}
& \phi=f a s e, \text { sem dimensão: }|\phi| \leqslant r . \\
& \text { Sendo, então, } z_{t} \text { a representação espectral }
\end{aligned}
$$

da sērie:

$z_{t}=\Sigma A_{\lambda} \operatorname{sen}\left(\lambda_{t}+\phi_{1}\right)$

uma medida do grau de atividade da série é a potencia (que decomposta pela anälise espectral permite o estudo da contri buição de cada frequência para a potência total), definida 
por:

$\lim _{T \rightarrow \infty} \frac{1}{2 T} \int_{-T}^{T} z^{2}(t) d t$

Como já foi salientado, a anälise espectral serà utilizada nesse trabalho como filtro para as sëries tem porais originais, correspondentes aos preços de carne bovina en diferentes niveis de mercado. Devido às características peculiares ao mercado em anälise, o período médio de duração de cada ciclo será considerado igual a 6 anos. Na literatura hà divergēncias sobre a duração desse ciclo, variando entre 5 e 7 anos; a escolha do periodo baseou-se em testes rea lizados por KASSOUF (1988), com o objetivo de prever preços na pecuária de corte paulista.

2.6. Margens de Comercialização

De acordo com BARROS (1987), a margem corresponde às despesas cobradas ao consumidor pela realizaçäo das atividades de comercialização, sendo utilizada principalmente para avaliar o desempenho dos mercados, através do acompa nhamento de sua evoluçāo.

As margens podem ser correntes ou defasadas. As margens correntes não levam em conta a defasagem que ocor re entre o instante de venda inicial do produto e o instante 
de sua compra final, portanto, podem não refletir integralmente os ajustamentos dos intermediärios às variações de pre ços. Quando as margens são medidas pelo diferencial de preços entre dois niveis de mercado num mesmo instante elas tendem a ser subestimadas, caso esteja ocorrendo uma fase de preços ascendentes, pois os preços nos diferentes niveis de mercado tendem a subir ou descer conjuntamente, de acordocom maior ou menor oferta do produto.Na figura 7 observa-se que MT é a margem calculada a partir dos preços de varejo ( $P v_{j}$ ) e do produtor $\left(P P_{1}\right)$, no instante $t$ de venda do produto. No entanto, se o produtor vendeu seu produto no instante $t_{0}$, a margem de comercialização deveria ser MT + $\overline{\dot{v}}$.

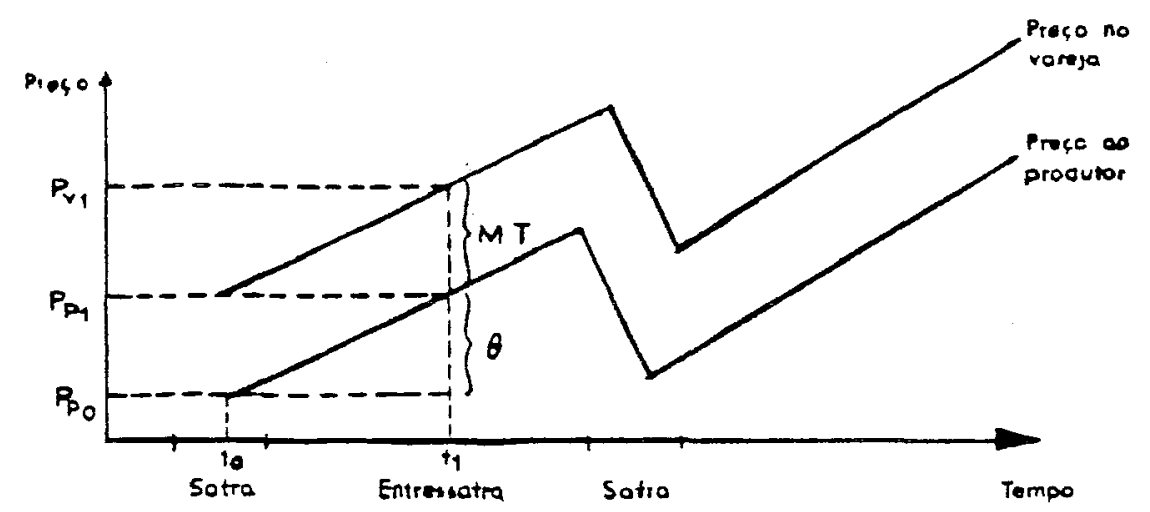

Figura 7. -Comportamento de preços e margens.

Fonte: BARROS (1987, p. 44). 
As margens de comercializaçāo podem ser absolutas ou relativas (totais ou específicas para cada nivel de mercado), ou ainda porcentuais. Essas margens podem ser alteradas em função de fatores como mudanças tecnológicas e al terações nos serviços de comercialização adicionados ao pro duto, sendo qué as margens relativas podem variar também com alteraçóes nos preços dos insumos agrícolas que elevam o prẹ ço ao produtor, nos insumos de comercialização ou na demanda do consumidor.

Pretende-se calcular os seguintes tipos de margens :

- Margem absoluta total de comercialização (MC), que é a diferença entre os preços pagos pelos consumidores e os valores recebidos pelos produtores:

$M C=P V-P P$

- Margem total relativa; expressa como propor ção do preço no varejo:

$M C^{\prime}=(P \vee-P P) / P \vee ;$

- Margem absoluta do varejista (MV):

$M V=P V-P a ;$

- Margem relativa do varejo (Mv'):

$M V^{\prime}=(P V-P a) / P V ;$

- Margem absoluta do atacado (MA):

$M A=(P a-P p):$ 
- Margem relativa do atacado (Ma'):

$M a^{\prime}=\left(P_{a}-P_{p}\right) / P v$

- Margem porcentual total de comercialização(MC'):

$M C^{\prime}=\frac{P V-P P}{P V} \cdot 100$

- Parcela porcentual do produtor (MP'):

$M P^{\prime}=\frac{P P}{P_{V}} \cdot 100$

- Margem porcentual do atacado (MA'):

$M A^{\prime}=\frac{P a-P P}{P V} \cdot 100 ;$

- Margem porcentual do varejo (MV'):

$M V^{\prime}=\frac{P V-P a}{P V} \cdot 100$.

Para o cálculo das margeñs defasadas, deve-se primeiro definir o sentido de causalidade entre os niveis de mercado e depois verificar o nümero de defasagens (d) necessárias para que o efeito sobre o preço endógeno se anule.

Por exemplo, se o preço no atacado causa o preço de varejo e o número de defasagens determinado é $d, a$ margem porcentual total defasada de comercialização (MC'd) $\vec{e}:$

$M C^{\prime} d=\frac{\left(P v_{t}-P P_{t-d}\right)}{P v_{t}} \cdot 100$

No caso de produtos processados durante a cadeia de comercialização, o preço recebido pelo produtor é 
transformado em quantidade equivalente na fazenda, de modo a separar o valor recebido pelo produtor pela venda de sua produção em duas partes, uma devida ao produto comercializado no varejo e outra devida aos subprodutos. Na Figura 8 , são representados os subprodutos que devem ser considerados no cälculo de margens de comercializaçäo de carne bovina e respectivos rendimentos. 


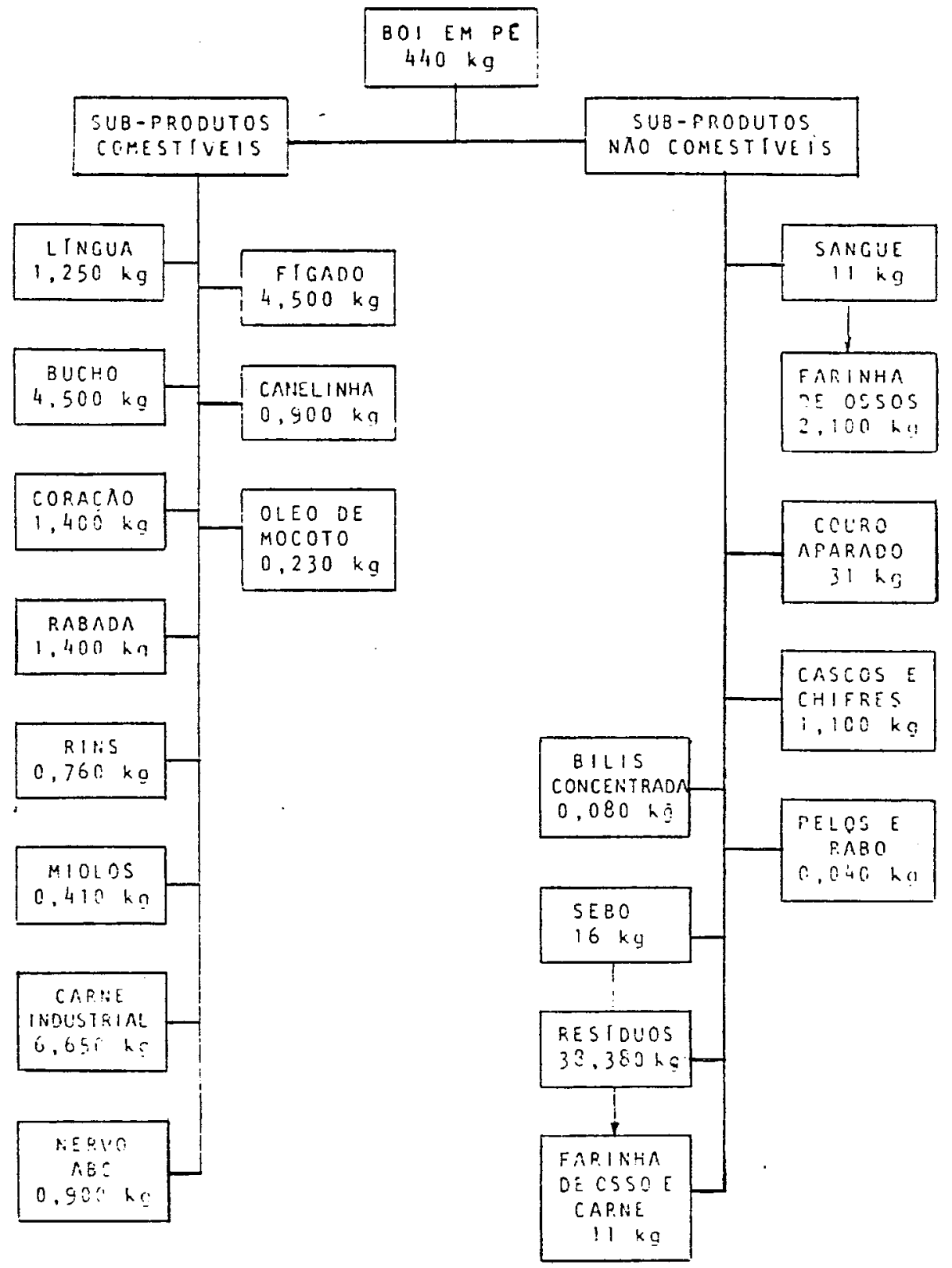

Figura 8. - Subprodutos para cálculo de margens de comercialização de carne bovina e respectivos rendimentos.

Fonte: CANTO (1986, p. 13). 
os principais resultados obtidos neste estudo serão discutidos a seguir.

3.1. Nümero de Defasagens Incluídas no Modelo

Foram realizados diversos testes de razão de verossimilhança, comparando modelos irrestritos com até 48 defasagens com modelos restritos com o mínimo de 6 defasagens. Ao nível de significância de $5 \%$ não houve indicações de que haveria necessidade de se incluir mais de 12 defasagens no modelo.

o teste que apresentou resultado mais significativo comparou um modelo irrestrito com 24 defasagens com um modelo restrito com 12 defasagens, resultando em um valor de $x^{2}$ igual a 115,3300 a 95 graus de 1 iberdade, significativo a $8 \%$. Comparando-se um modelo irrestrito de 12 defasagens com um modelo restrito de 6 defasagens, o resultado obtido $\left(x^{2}=52,1011\right.$, 54 graus de liberdade, nivel de significancia $=54,79 \%$ ), mostrou que não haveria necessidade de se utilizar o modelo irres trito, sugerindo a utilização de apenas 6 defasagens.

No entanto, diante dos resultados obtidos nos vários testes de razão de verossimilhança optou-se pela utilização de 12 defasagens para estimar os parämetros de cada representação auto-regressiva de processo estocástico vetorial utilizada. 


\subsection{Anälise de causalidade}

Os resultados da anälise de causalidade para carne bovina realizada segundo o modelo de auto-regressão ve torial são representados nas tabelas 4 a 6 e os resultados obtidos de acordo com método sugerido por BISHOP(1979) são apresentados na tabela 7 .

A anälise de dos resultados dos testes de F da tabela 4 captou efeito causal no sentido dos preços ao vạ rejo para os preços ao atacado, ao nível de significancia de $8 \%$. Foi captada também causalidade dos preços recebidos pelos produtores paulistas para o mercado atacadista aos níveis de 12 e $14 \%$. Os preços a nível de atacado mostraram não afetar de forma significativa os demais preços e o sentido de causalidade entre os preços não se alterou em função dos diferentes filtros utilizados. Diante desses resultados, as evidências são fracas quanto à probabilidade de efeito causal entre as variäveis consideradas.

As anälises da tabela 5 excluem o nivel de atacado, pois no decorrer das anälises, tanto de transmissäo de preços como de margens de comercialização, alguns resulta dos sugeriram que os dados a nivel de atacado apresentavam distorções. Essas possíveis distorçōes podem resultar tanto de imperfeições no sistema de coleta e processamento dos dados primärios como da pröpria política de preços governamen- 
Tabela 4.- Comparação de niveis de significância dos Testes $F\left({ }^{1}\right.$ ) na anālise de causalidade da carne bovina, atravēs de auto-regressōes vetoriais compostas das variáveis A, V e PSP( ${ }^{2}$ ), períodol971/87.

\begin{tabular}{|c|c|c|c|c|}
\hline \multicolumn{2}{|c|}{ FILTRO $\left({ }^{3}\right)$ VARIÄVEL DEPENDENTE $\left({ }^{4}\right)$} & \multicolumn{3}{|c|}{ VARIÁVEIS INDEPENDENTES } \\
\hline \multirow[b]{2}{*}{$(28,77 ; 0,88)$} & \multirow[b]{2}{*}{$A$} & PSP & \multirow{2}{*}{$\frac{v}{26,00(1,24)}$} & A \\
\hline & & $19,00(1,37)$ & & $0 \quad(10,97)$ \\
\hline$(40,09 ; 0,42)$ & V & $22,00(1,31)$ & $0 \quad(5,58)$ & $68,00(0,77)$ \\
\hline$(32,54 ; 0,75)$ & PSP & $0 \quad(14,55)$ & $27,50(1,21)$ & $75,50(0,69)$ \\
\hline$(11)(49,80 ; 0,11)$ & A & $37,00(1,09)$ & $33,50(1,14)$ & $(12,12)$ \\
\hline$(41,89 ; 0,34)$ & v & $61,00(0,83)$ & $0 \quad(7,09)$ & $51,00(0,94)$ \\
\hline$(44,59 ; 0,24)$ & PSP & $0 \quad(17,64)$ & $36,50(1,09)$ & $61,00(0,84)$ \\
\hline$(111 \nmid 31,44 ; 0,80)$ & A & $12,00(1,52)$ & $38,00(1,07)$ & $0 \quad(3,75)$ \\
\hline$(34,04 ; 0,69)$ & V & $26,00(1,24)$ & $0 \quad(5,69)$ & $30,00(1,18)$ \\
\hline$(27,13 ; 0,92)$ & PSP & $0 \quad(7,83)$ & $26,00(1,24)$ & $54,50(0,90)$ \\
\hline (IV) $(34,36 ; 0,68)$ & A & $14,50(1,45)$ & $8,00 \quad(1,66)$ & $(11,19)$ \\
\hline$(31,72 ; 0,79)$ & V & $69,50(0,75)$ & $(7,79)$ & $72,00(0,72)$ \\
\hline$(34,41 ; 0,67)$ & PSP & $(10,51)$ & $28,50(1,20)$ & $63,50(0,81)$ \\
\hline (v) $(39,47 ; 0,44)$ & A & $23,00(1,28)$ & $23,50(1,28)$ & $(10,43)$ \\
\hline$(29,60 ; 0,86)$ & v & $55,00(0,90)$ & $0 \quad(6,49)$ & $68,00(0,77)$ \\
\hline$(33,22 ; 0,73)$ & PSP & $(11,62)$ & $51,00(0,93)$ & $71,50(0,73)$ \\
\hline
\end{tabular}

${ }^{1}$ ) entre parênteses estão os valores de $F$.

$\left.{ }^{2}\right)$ A, V e PSP referem-se aos preços reais de carne bovina recebidos pelos mercados atacadista e varejista da cidade de São Paulo e pelos produtores do Estado de São Paulo, respectivamente.

$\left({ }^{3}\right)$ (1) preços reais recebidos a cada nivel de mercado.

(11) logaritmos naturais dos preços reais recebidos pelos mercados.

(III) séries de preços reais transformadas por anälise espectral.

(IV) séries de preços reais no varejo transformada por anälise espectral é o filtro.

(V) série de preços reais no atacado transformada por anālise espectral è o filtro.

entre parēnteses estão os valores do teste $Q$ e seus níveis de signifi cāncia.

$\left({ }^{4}\right)$ a ordenação das variäveis foi: A, V e PSP. 
tais. Essa tabela capta efeito causal no sentido dos preços recebidos pelos produtores paulistas para os preços recebidos pelo mercado varejista, ao nivel de $4 \%$ de significància, no modelo de auto-regressão vetorial em que não foram utilizados os logaritmos naturais das variäveis.

Com relação aos demais Estados produtores considerados nas anälises, o modelo de auto-regressão vetorial utilizando os logaritmos naturais dos preços de mercado indica a existência de causalidade ao nivel de $5 \%$ dos mercados varejista e atacadista sobre o mercado produtor de Minas Gerais (tabela 6). A outros niveis de significancia foi captada causalidade do varejo e do atacado sobre os produtores de Mato Grosso e Goì̃s.

A anälise de causalidaderepresentada na tabela 7 , utilizando preços reais a cada nivel de mercado, não detectou a $5 \%$ de significancia causalidade dos produtores de São Paulo, Mato Grosso, Goiàs, Minas Gerais e Rio Grande do Sul para os mercados varejista e atacadista. Porém, captou efeito causal no sentido do mercado varejista sobre os produtores dos cinco Estados analisados e sobre o mercado atacadista. 0 nível de atacado mostrou não interferir nos mercados produtor e varejista paulistas, mas foi captado efeito causal no sentido do atacado para os preços recebidos pelos demais mer cados produtores analisados. 
Tabela 5.- Comparação de niveis de significância dos testes $F\left({ }^{1}\right)$ na anälise de causalidade da carne bovina, através de auto-regressöes vetoriais compostas das variāveis V e PSP $\left(^{2}\right)$, período 1971/87.

\begin{tabular}{|c|c|c|c|}
\hline \multirow[t]{2}{*}{ FILTRO $\left({ }^{3}\right)$} & \multirow[t]{2}{*}{$=L \quad$ DEPENDENTE $\left({ }^{4}\right)$} & \multicolumn{2}{|c|}{ VARIAVEIS INDEPENDENTES } \\
\hline & & $\mathrm{v}$ & PSP \\
\hline (1) $(30,77 ; 0,82)$ & v & $0 \quad(6,31)$ & $4,00(1,88)$ \\
\hline$(34,56 ; 0,79)$ & PSP & $21,00(1,32)$ & $(20,25)$ \\
\hline$(11)(35,13 ; 0,64)$ & v & $0 \quad(8,24)$ & $23,00(1,28)$ \\
\hline$(41,38 ; 0,36)$ & PSP & $23,00(1,28)$ & $(23,38)$ \\
\hline$(1.11)_{29,87 ; 0,85)}$ & v & $0 \quad(5,28)$ & $15,50(1,44)$ \\
\hline$(28,13 ; 0,90)$ & PSP & $18,00(1,38)$ & $(9,00)$ \\
\hline (IV) $(31,86 ; 0,78)$ & $v$ & $(\varepsilon, 25)$ & $40,00(1,06)$ \\
\hline$(32,04 ; 0,77)$ & PSP & $21,00(1,32)$ & $(14,80)$ \\
\hline \multirow{2}{*}{$\begin{array}{l}(1) \quad(31,56 ; 0,79) \\
(30,77 ; 0,82)\end{array}$} & PSP & $21,00(1,32)$ & $(20,25)$ \\
\hline & v & $(6,31)$ & $4,00(1,88)$ \\
\hline
\end{tabular}

${ }^{1}$ ) entre parènteses estão os valores de $F$.

${ }^{2}$ ) V e PSP referem-se aos preços reais de carne bovina recebidos pelo mercado varejista da cidade de São Paulo e pelos produtores do Estado de São Paulo, respectivamente.

$\left({ }^{3}\right)$ (1) preços reais recebidos nos dois niveis de mercado.

(11) logaritmos naturais dos preços reais recebidos pelos mercados. (111)séries de preços reais transformadas por anälise espectral. (IV) séries de preços reais no varejo transformada por anālise espectral é o filtro.

entre parênteses estão os valores do teste $Q$ e seus níveis de signifi cância.

$\left({ }^{4}\right)$ Nas quatro primeiras equações a ordenação das variäveis é V, PSP, na quinta equação a ordenação das variäveis é PSP e $V$. 
Tabela 6. - Niveis de significância dos testes $F\left({ }^{2}\right.$ ) na anälise de causalidade da carne bovina através de auto-regressões vetoriais, utilizando logaritmos naturaisdos preços de mercado como filtro, período $1971 / 87$.

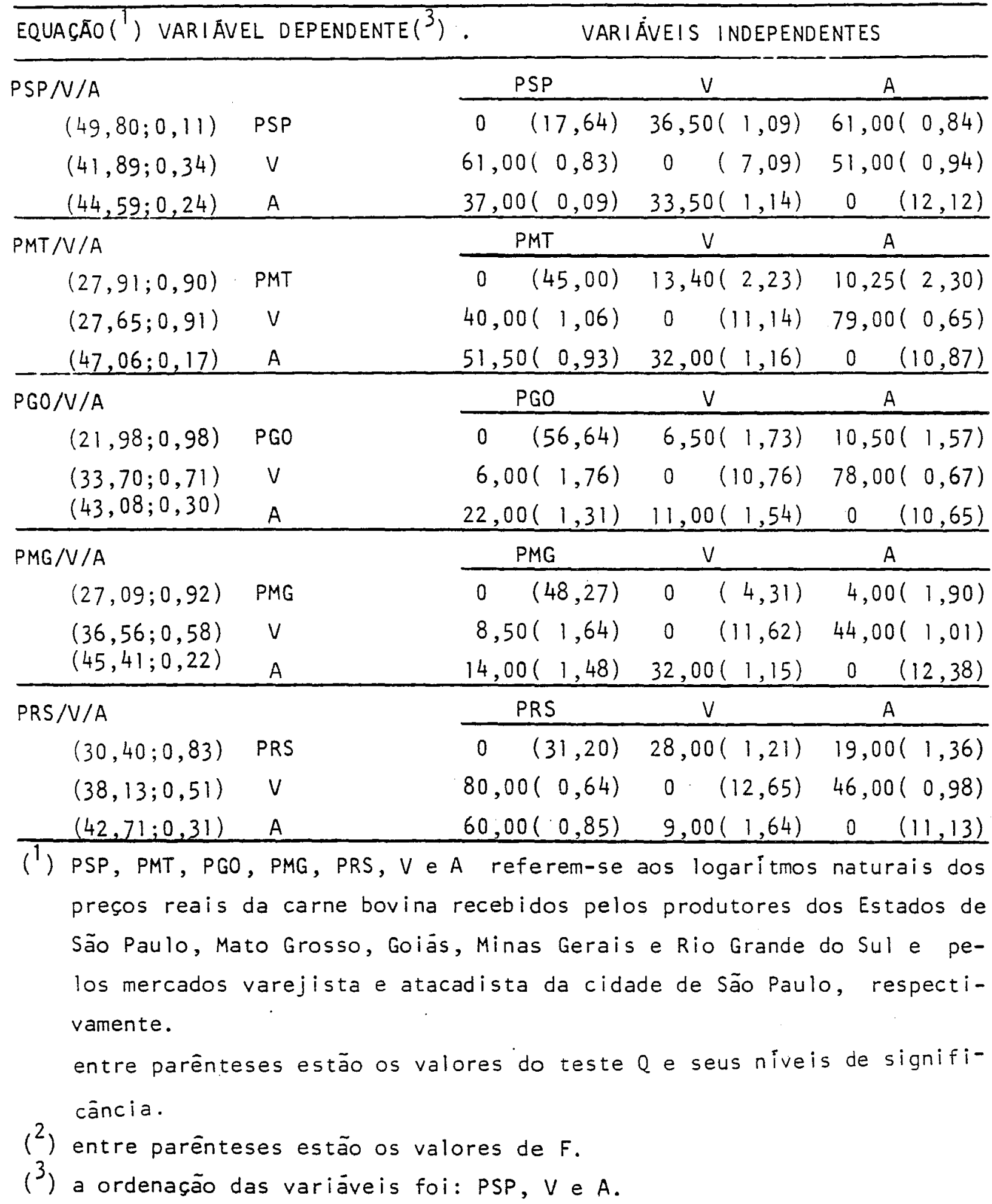


Tabela 7.- Testes para exclusão de variāveis futuras na anālise de causalidade da carne bovina, segundo método sugerido por BISHOP (1979), período 1971/87 (12 e 140 graus de liberdade).

\begin{tabular}{|c|c|c|c|}
\hline EQUAÇÃO $\left({ }^{1}\right)$ & VARIÁVEL DEPENDENTE & $F$ & NTVEL DE SIGNIFICÃNCIA(\%) \\
\hline \multirow[t]{2}{*}{ PSP/V } & PSP & 1,27 & 24,00 \\
\hline & V & 1,67 & $8,00^{\circ}$ \\
\hline \multirow[t]{2}{*}{$P S P / A$} & PSP & 1,52 & 12,00 \\
\hline & A & 1,25 & 25,00 \\
\hline \multirow[t]{2}{*}{$\mathrm{PMT} / \mathrm{V}$} & PMT & 1,61 & 9,50 \\
\hline & V & 3,33 & 0 \\
\hline \multirow[t]{2}{*}{$\mathrm{PMT} / \mathrm{A}$} & PMT & 1,06 & 39,50 \\
\hline & $A$ & 2,03 & 2,50 \\
\hline \multirow[t]{2}{*}{ PGO/V } & $P G O$ & 2,10 & 2,00 \\
\hline & V & 2,73 & 0,24 \\
\hline \multirow[t]{2}{*}{$P G O / A$} & PGO & 1,54 & 11,80 \\
\hline & A & 1,87 & 4,25 \\
\hline \multirow[t]{2}{*}{$P M G / V$} & PMG & 1,87 & 4,30 \\
\hline & V & 5,64 & 0 \\
\hline \multirow[t]{2}{*}{$P M G / A$} & PMG & 1,44 & 15,50 \\
\hline & A & 1,54 & 11,75 \\
\hline \multirow[t]{2}{*}{ PRS/V } & PRS & 0,98 & 47,00 \\
\hline & V & 1,81 & 5,00 \\
\hline \multirow[t]{2}{*}{ PRS/A } & PRS & 1,16 & 31,50 \\
\hline & A & 1,75 & 6,00 \\
\hline \multirow[t]{2}{*}{$V / A$} & V & 1,39 & 17,40 \\
\hline & A & 1,03 & 42,00 \\
\hline
\end{tabular}

(') PSP, PMT, PGO, PMG, PRS, V e A, referem-se aos preços reais da carne bovina recebidos pelos produtores dos Estados de São Paulo, Mato Grosso, Goiàs, Minas Gerais e Rio Grande do Sul, e pelos mercados varejista e atacadista da cidade de São Paulo, respectivamente. 
os resultados obtidos pelos dois métodos utilizados não detectaram influēncia dos preços recebidos pelos produtores de Mato Grosso, Goiàs, Minas Gerais e Rio Grande do sul sobre os preços dos mercados varejista e atacadista da cidade de são paulo. No entanto, captaram causalidade dos preços recebidos pelos produtores paulistas sobre os niveis de atacado e varejo e destes para os preços recebidos pelos produtores utilizados. Nenhum dos mercados analisados mostrou-se essencialmente exōgeno.

Quanto a eficácia dos filtros utilizados, o teste $Q$ (tabelas 4,5 e 6 ) mostrou que os modelos que utilizaram como filtro os logaritmos das variáveis em anälise foram mais eficazes.

3.3. Mecanismos de Propagação de Choques

Em função dos resultados obtidos na anàlise de causalidade decidiu-se analisar de forma especifica os mecanismos de propagaço de choques no sistema constituido pelos seguintes niveis de mercado: preços recebidos pelos produtores paulistas (PSP) e preços a nivel de atacado e varejo no merçado consumidor da cidade de são paulo (A e V, respectivamente). Foram utilizados nesse sistema os logaritmos naturais dos preços reais de mercado, possibilitando analisar também as elasticidades de transmissão de preços de um nivel para outro de mercado. 
Convëm ressaltar que embora possa haver ausência de causalidade entre determinadas variáveis o efeito de choques em uma delas poderá ser transmitido para todo o sistema. A importāncia da ordenação das variäveis no sistema também deve ser ressaltada, pois inovações na primeira variàvel da ordem afetam as demais variáveis contemporaneamente, sem que a primeira seja afetada por elas. Da mesma forma, a segunda variável pode impactar as posteriores sem ser afetada contemporaneamente por inovaçóes em nenhuma delas.

Considerando os itens acima ressaltados e os resultados da anälise de causalidade, optou-se pela utilização da seguinte ordenação das variäveis: PSP, V e A. Portanto, choques a nivel de produtor poderäo afetar todos os níveis de mercado, choques no varejo poderão afetar o atacado, porém choques nos preços de atacado não se refletirão sobre as demais variäveis.

Nas figuras 9 a 11 , referentes às tabelas 8 a 10 , estão representadas as respostas por 48 meses dos choques unitärios em PSP, $V$ e A, respectivamente, sobre as demais unidades do sistema. No apêndice 2 estão representados os efeitos de choques de uma unidade de desvio padräo sobre PSP, V e A (tabelas 39 a 41 ).

os efeitos de choques representados nas figuras 9 a 11 correspondem às elasticidades de transmissão de preços entre os níveis de mercado, pois a regressão foi rea- 
Tabela 8. - Respostas a um choque de uma unidade em PSP( $\left.{ }^{1}\right)$

\begin{tabular}{|c|c|c|c|}
\hline Macs & Sobre PSP & Sobre V & Sobre A \\
\hline $11:$ & 1. 00111104. & 1). $111: 2::_{1}$ & $0 . / 11 / 0.11$ \\
\hline i.: & 1.119219 & ט. you $0<4$ & 0.831334 \\
\hline 03 & 1.006014 & 0.870410 & $0.72 ; 110$ \\
\hline 0 & 0.920906 & 0.775053 & 0.682915 \\
\hline 03 & 0.871030 & $0 . \dot{717089}$ & 0.688705 \\
\hline 06 & $0.75,6000$ & 0.617274 & $0.614 / 68$ \\
\hline $0:$ & 0.621298 & 0.467943 & $0.4585,77$ \\
\hline $0 ?$ & 0.509509 & 0.399285 & ii. 359013 \\
\hline $0:$ & 0.638338 & $0.4 \cup 5143$ & 0.563485 \\
\hline 0 & 0.560520 & 0.269345 & $4.4555 \mathrm{~s}$ \\
\hline$i$ & $0.54 i 668$ & 0.288961 & 0.419003 \\
\hline$\vdots:$ & 0.531822 & 0.260513 & 0.393628 \\
\hline$\therefore ;$ & 0.492526 & 0.276601 & $0.423 ; 00$ \\
\hline 1.4 & 0.441230 & 0.217131 & 0.514080 \\
\hline $1 \%$ & 0.406160 & 0.332444 & 0.551911 \\
\hline 10 & $0.30 \div 838$ & 0.284274 & J $50 ? 634$ \\
\hline $1 !$ & 0.229288 & 0.244131 & 0.400061 \\
\hline 18 & 0.160755 & 0.191675 & 0.335061 \\
\hline 19 & 0.105597 & 0.103123 & 0.315200 \\
\hline $2 i$ & $0.0070: 4$ & $0.07958 \%$ & 0.173228 \\
\hline 2 & - 0. 03853 & 0.051630 & $0.09077 \mathrm{i}$ \\
\hline $2 ?$ & -0.08312 & 0.011991 & 0.033629 \\
\hline 23 & -0.09609 & -0.00669 & 0.0167:2? \\
\hline $2 i_{1}$ & -0.12733 & -0.02304 & C.UCDi4u \\
\hline 23 & -0.14986 & -0.03680 & 0.615833 \\
\hline 26 & -0.17034 & -0.05295 & 0.023991 \\
\hline $2 \because$ & -0.19195 & -0.09919 & $0.0 j u n u 4$ \\
\hline $2 \theta$ & -0.22952 & -0.68237 & $0.0 \cup 18.15$ \\
\hline $2:$ & -0.24361 & $-0.086: 0$ & -0.02051 \\
\hline $3 i$ & -0.27530 & $-0.1: 437$ & -0.67030 \\
\hline$\overline{3}$ & -0.28217 & $-0.1234,8$ & -0.10036 \\
\hline $3 \because$ & -0.28912 & -0.13993 & -0.13652 \\
\hline $3 \because$ & -0.28772 & -0.15290 & -0.16026 \\
\hline $3 i$ & -0.20029 & $-0.160 i 5$ & -0.17120 \\
\hline $3:$ & -0.26384 & -0.15848 & - 0. lutíg \\
\hline 36 & $-0.2499 u$ & -0.55366 & -0.15800 \\
\hline $3 i$ & -0.23068 & $-0.1431,8$ & -6.14320 \\
\hline $3:$ & -0.21994 & -0.13862 & -0.13083 \\
\hline $3 ! 1$ & -0.25323 & -6.12612 & -0.12863 \\
\hline 40 & -0.19218 & -0.12307 & $-0.15 \vdots 11$ \\
\hline 4: & -0.17942 & -0.11625 & -0.13354 \\
\hline $4:$ & -0.16798 & $-0.1 \div 464$ & -0.14552 \\
\hline $4 \vdots$ & -0.15218 & -0.11115 & -0.14306 \\
\hline $4 i$ & -0.130009 & -0.10070 & -0.14463 \\
\hline $4 \vdots$ & -0.11570 & -0.09306 & -6.13034 \\
\hline $4 i$ & -0.09589 & -0.09025 & -0.2583 \\
\hline 4 & -0.07445 & -0.07762 & -0.11455 \\
\hline 18 & -0. io $, 5,1,8$ & $-1 i$. $\cup 60,1,6$ & - J e (a) \\
\hline
\end{tabular}

(1) PSP, V e A referem-se aos preços reais de carne bovina recebidos pelos produtores do Estado de São Paulo e pelos mercados varejistas e atacadistas da cidade de São Paulo, respectivamente. Modelo estimado com 12 defasagens. 
Tabela 9. - Respostas a um choque de uma unidade em $V\left({ }^{\prime}\right)$

\begin{tabular}{|c|c|c|c|}
\hline Mcses & Sobre PSP & Sobre V & Sobre \\
\hline 01 & 0 & 1,000000 & 0,370056 \\
\hline 02 & 0.161418 & 0,980251 & 0,433945 \\
\hline 03 & 0,099878 & 0,722325 & 0,335902 \\
\hline 04 & $-0,147040$ & 0,405316 & 0.180056 \\
\hline 05 & $-0,239899$ & 0,074210 & 0.009651 \\
\hline 06 & $-0,415948$ & $-0,187727$ & $-0,210998$ \\
\hline 07 & $-0,567122$ & $-0,308421$ & $-0,379478$ \\
\hline 08 & -0.338519 & $-0,143364$ & $-0,151961$ \\
\hline 09 & -0.207535 & -0.099277 & -0.062162 \\
\hline 10 & $-0,177021$ & $-0,120648$ & 0,059388 \\
\hline 11 & 0,010518 & 0.072738 & 0,265449 \\
\hline 12 & -0.029897 & 0,046982 & 0,294008 \\
\hline 13 & $-0,066254$ & 0,025981 & 0.335859 \\
\hline 14 & $-0,105419$ & 0.032818 & 0,320924 \\
\hline 15 & $-0,166389$ & 0,005612 & 0,241632 \\
\hline 16 & $-0,188172$ & $-0,032464$ & 0,155961 \\
\hline 17 & $-0,225062$ & $-0,103614$ & 0,001156 \\
\hline 18 & $-0,204148$ & $-0,079116$ & $-0,077684$ \\
\hline 19 & $-0,172996$ & $-0,125645$ & $-0,148398$ \\
\hline 20 & $-0,191404$ & $-0,171133$ & $-0,230641$ \\
\hline 21 & $-0,170240$ & $-0,146412$ & $-0,205523$ \\
\hline 22 & $-0,144213$ & $-0,149708$ & $-0,180807$ \\
\hline 23 & $-0,140874$ & $-0,128524$ & $-0,130389$ \\
\hline 24 & $-0,136670$ & $-0,107118$ & $-0,079608$ \\
\hline 25 & $-0,127453$ & -0.090925 & $-0,067941$ \\
\hline 26 & $-0,136847$ & $-0,0852 i 7$ & -0.052359 \\
\hline 27 & $-0,155995$ & $-0,10380 i$ & $-0,053856$ \\
\hline 28 & $-0,157020$ & $-0,0936: 4$ & $-0,121979$ \\
\hline 29 & $-0,160626$ & $-0,109462$ & $-0,160499$ \\
\hline 30 & $-0,136809$ & $-\because, 123308$ & $-0,190722$ \\
\hline 32 & $-0,133695$ & -108455 & $-0,188211$ \\
\hline 32 & $-0,112114$ & $-0,104428$ & $-0,174892$ \\
\hline 33 & $-0,081745$ & $-0,088063$ & $-0,142274$ \\
\hline 34 & $-0,058335$ & $-0,069032$ & $-0,105521$ \\
\hline 35 & $-0,037367$ & $-0,049465$ & $-0,071168$ \\
\hline 36 & $-0,018818$ & $-0,029507$ & $-0,0 \div 184 !$ \\
\hline 37 & $-0,014135$ & $-0,0210 ? 6$ & -0.031571 \\
\hline 38 & $-0,007160$ & $-0,010535$ & $-0,026772$ \\
\hline 39 & $-0,000464$ & -0.006748 & -6.030363 \\
\hline 40 & 0,001648 & $-0,008908$ & $-0,0 \div 1346^{\circ}$ \\
\hline 41 & 0,011385 & -0.005014 & $-0,042308$ \\
\hline 42 & 0,521036 & $-0,006500$ & $-\bar{v}, 04351 \bar{t}$ \\
\hline$\therefore 3$ & 0,032373 & $-0,002580$ & -0.035952 \\
\hline 44 & 0,045434 & 0,004190 & $-0,421755$ \\
\hline 45 & $0,0567 i 1$ & 0,012813 & $-0,005372$ \\
\hline 46 & 0,066318 & 0,023248 & $\therefore, 01298 i$ \\
\hline 67 & 0,071980 & $0,0,3059=$ & $\therefore, 057351$ \\
\hline$\therefore \varepsilon$ & 0,074424 & $0,037 \in 89$ & 0.037490 \\
\hline
\end{tabular}

(1) PSP, V e A referem-se aos preços reais da carne bovina recebidos pelos produtores do Estado de São Paulo e pelos mercados varejista e atacadista da cidade de São Paulo, respectivamente. Modelo estimado com 12 defasagens. 
Tabela 10. -Respostas a um choque de uma unidade em $A\left({ }^{1}\right.$ )

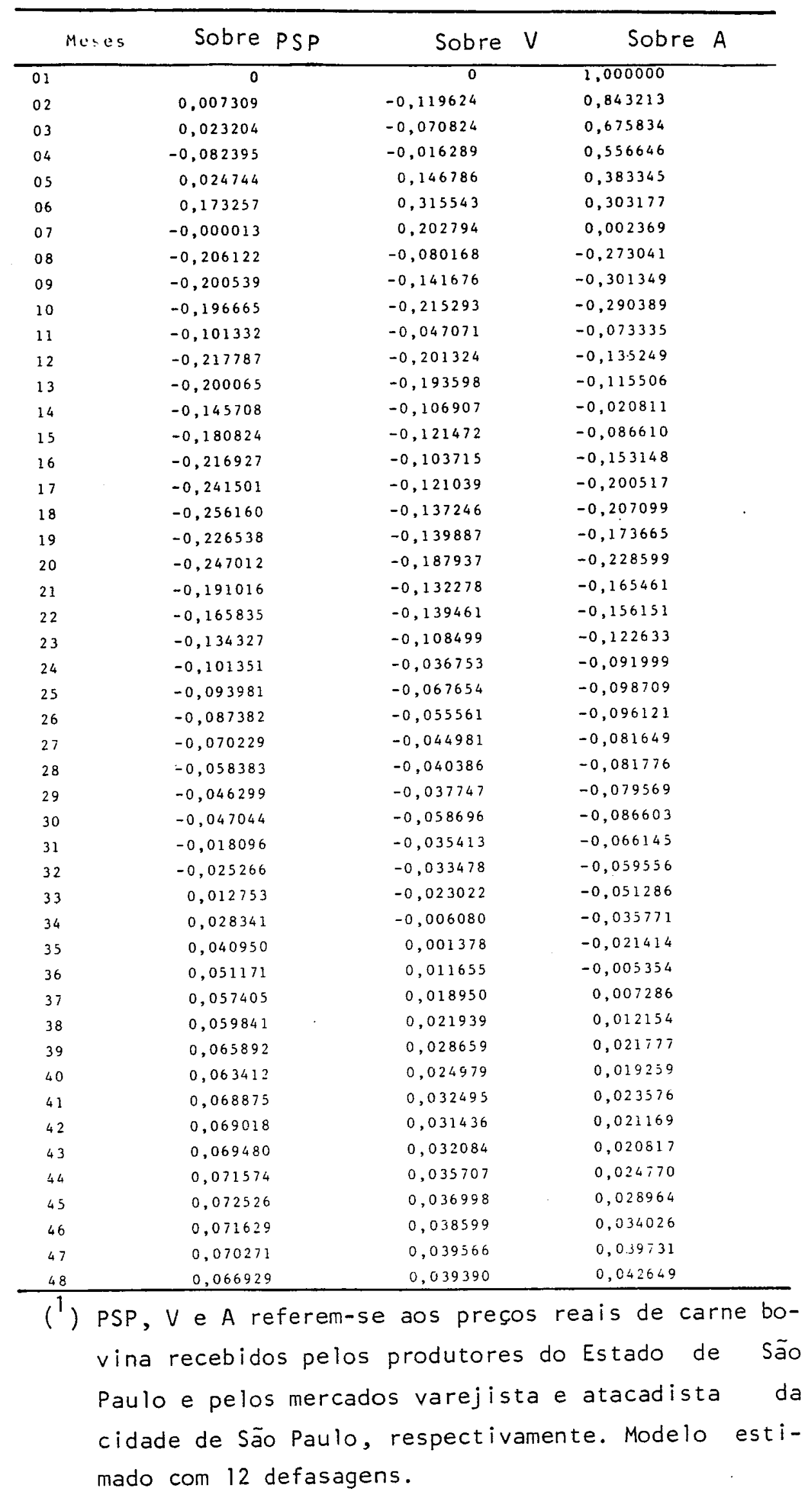




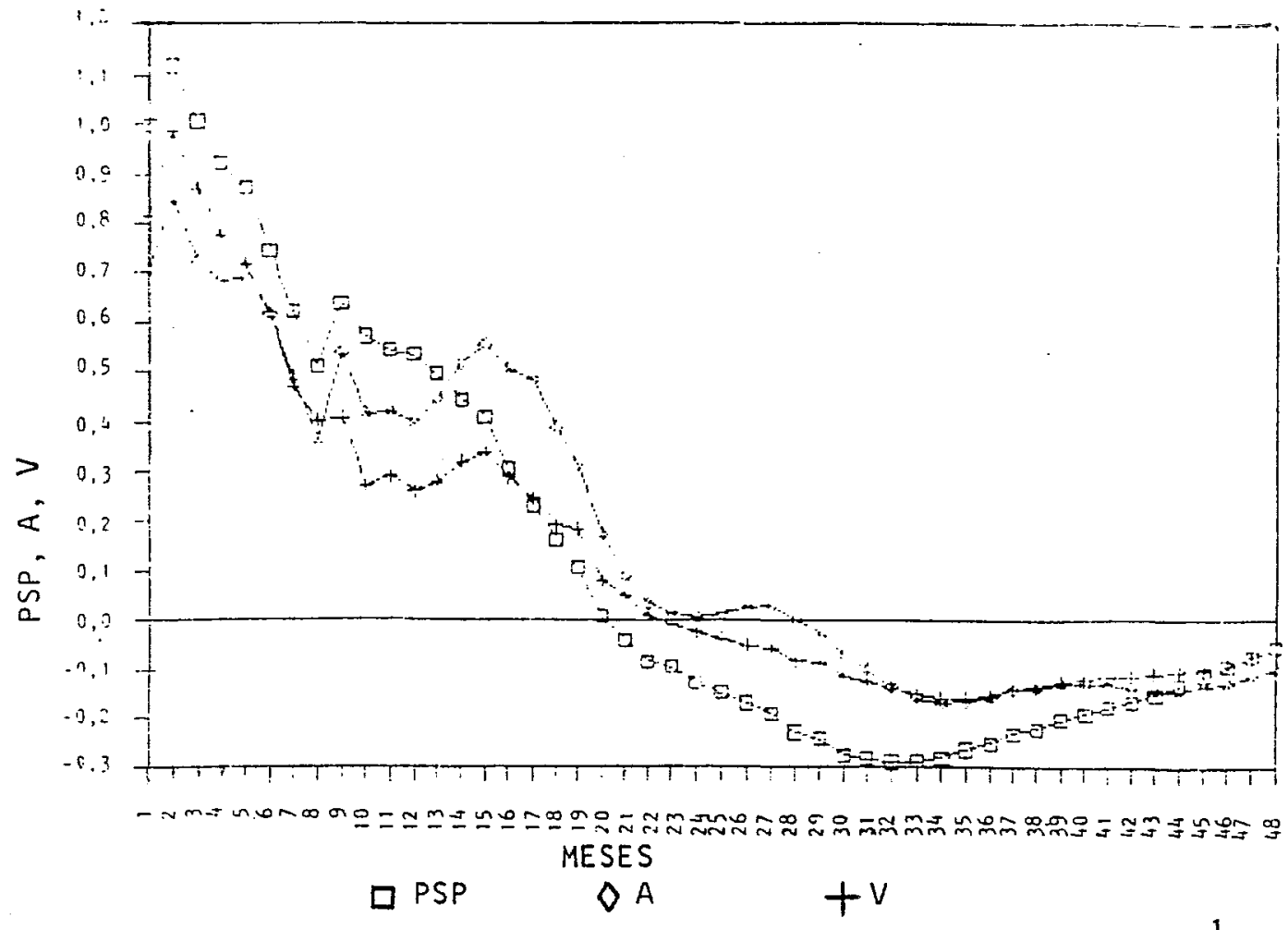

Figura 9 . - Respostas a um choque de uma unidade em PSP( ${ }^{1}$ )

(') PSP, A e V: preços recebidos pelo produtor de São Paulo, atacado e varejo, respectivamente.

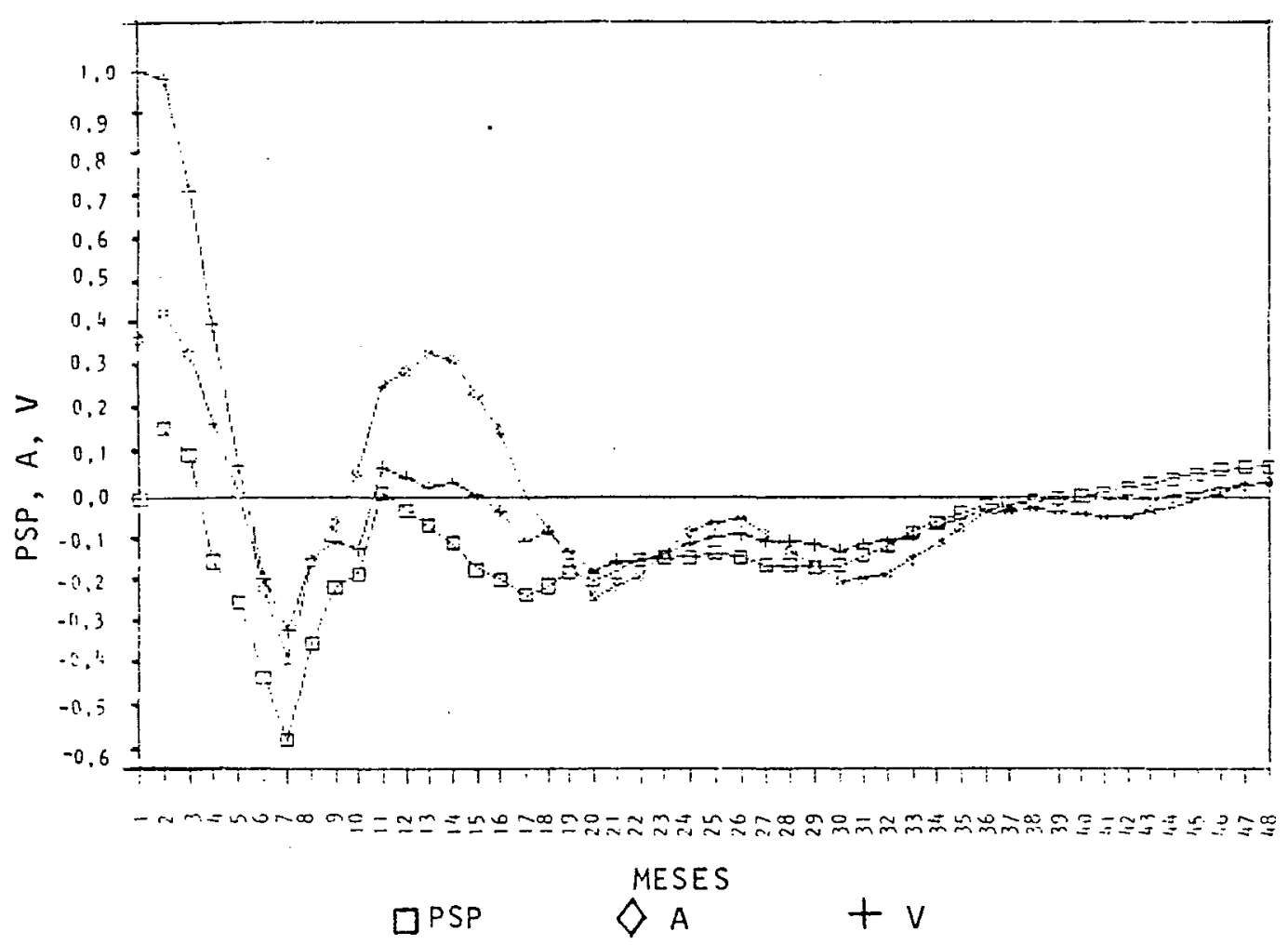

Figura 10.- Respostas a um choque de uma unidade em $V\left({ }^{1}\right)$ (') PSP, A e V: preços recebidos pelo produtor de São Paulo, atacado e varejo, respectivamente. 


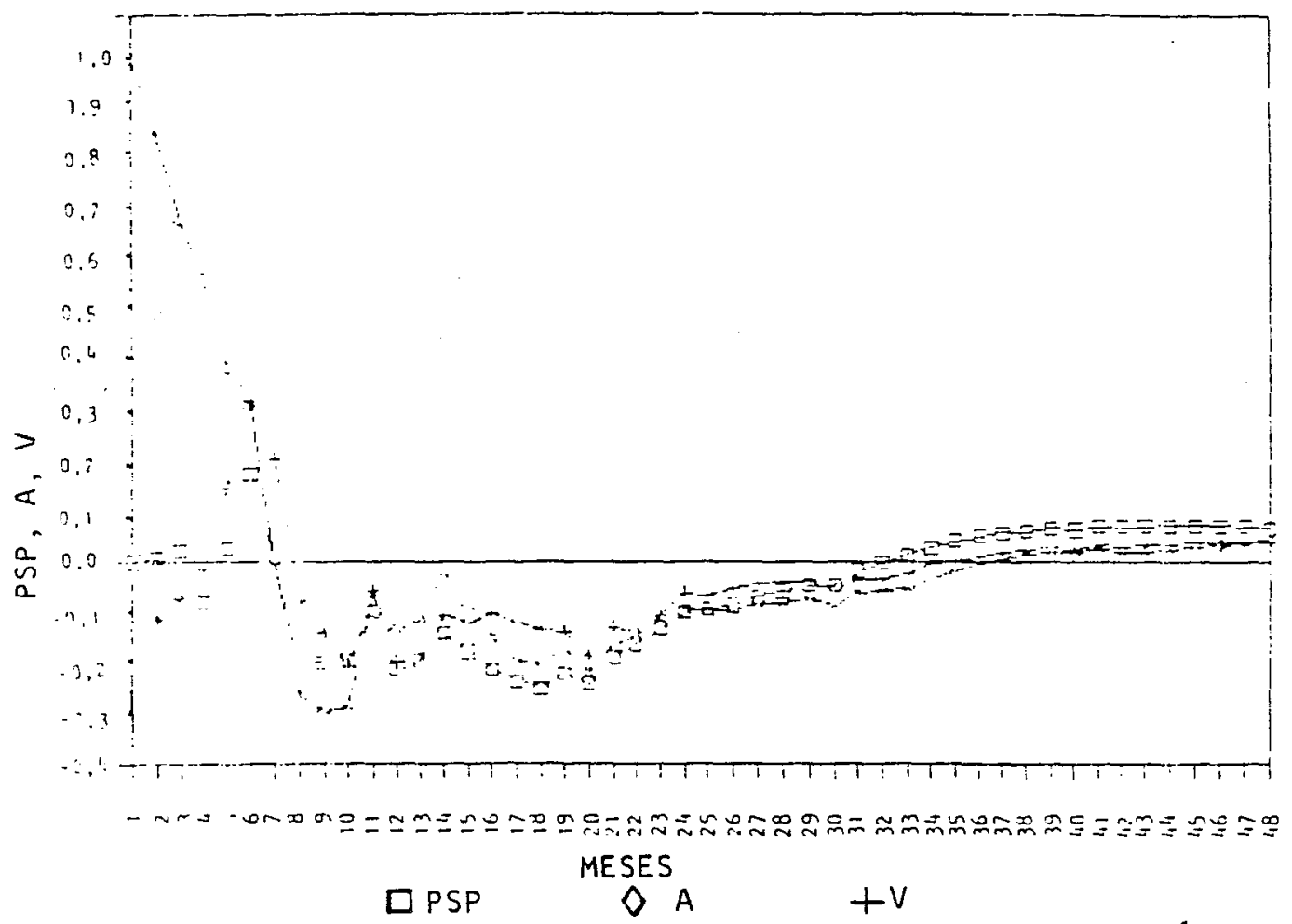

Figura 11.- Respostas a um choque de uma unidade emi $A\left({ }^{1}\right)$

(1) PSP, A e V: preços recebidos pelo produtor de São paulo, atacado e varejo, respectivamente.

lizada utilizando os logaritmos naturais dos preços e foram aplicados choques unitários sobre cada variável.

$$
\text { Podemos identificar nesses resultados trés }
$$

espécies de elasticidade de transmissäo de preços: elasticidade instantānea, elasticidade parcial e elasticidade final (de um nivel para outro de mercado ou dentro de um mesmo níve i). 
Na tabela 8 pode-se observar, então, elasticidade de transmissão de preços instantánea do produtor para ovarejo igual a 0,8128 , do produtor para o atacado igual a 0,7070 (no primeiromês) e a elasticidade a nivel de produtor é igual a 1,1192, do primeiro para o segundo més. Um exemplo de elasticidade parcial seria a existente do primeiro para o oitavo més, a nível de produtor, igual a 0,5096 . Do primeiro para o quadragésimo oitavo més temos elasticidade final.

Dessa forma, um aumento de $10 \%$ nos preços recebidos pelos produtores paulistas provocaria aumentos imediatos de $8,128 \%$ nos preços de varejo e de $7,070 \%$ nos preços de atacado. Além disso, face ao choque inicial, o preço ao produtor acumula um aumento de $11,192 \%$ no segundo mês.

Pode-se analisar as tabelas 9 e 10 da mesma forma que a tabela 8 , verificando-se, porém, que um choque de uma unidade sobre o varejo afeta instantāneamente o atacado mas não o produtor e que o mesmo tipo de choque sobre o atacado não afeta instantāneamente os demais níveis de mercado.

observando-se a figura 9 , verifica-se que as elasticidades de transmissão de preços crescem do primeiro para o segundo més. Do segundo ao oitavo mès seus valores caem, apresentam certa recuperação do nono ao décimo quinto mês e a partir desse mês voltam a cair, tornando-se pratica- 
mente nulos por volta do vigésimo quarto mès.

Na figura 10 , observa-se queda brusca dos efeitos de choques sobre os preços do segundo ao quinto més, quando eles passam a crescer. Ao redor do décimo segundo mês os valores voltam a cair, estabilizando-se por volta do vigès imo més.

Na figura 11 , observa-se que o efeito de um choque de uma unidade sobre os preços de atacado decresce rapidamente atē o sētimo més. Do sētimo ao vigēsimo més os preços estabilizam-se, tornam-se nulos ao redor do trigésimo mês e voltam a se estabilizar.

Verifica-se que a intensidade dos efeitos de choques sobre os níveis de varejo e atacado decresce rapidamente, tornando-se nulos nos primeiros meses apös a ocorrēncia dos choques.

No entanto, os efeitos dos choques sobre o nivel produtor persistem por período mais longo. Esse resultado sugere que as polfticas de preços que atuem especificamente sobre o nivel produtor de carne bovina são mais importantes do que aquelas que atuam diretamente sobre os demais niveis de mercado, pois seus efeitos tendem a se refletir so bre o mercado, de forma sianificativa,durante cerca de trinta meses. Deve-se salientar o importante resultado de que os efeitos dos choques iniciais tendem a se reverter - trocar de sinalapös o vigésimo mês e a desaparecer ou tornar-se desprezíveis 
dentro do horizonte em anälise. Lembre-se, no entanto, que essas flutuações convergentes se dão ao redor da tendéncia ascendente de preços (que foi eliminada nesta parte da aná(ise).

Assim, um aumento de preços, por exemplo, tende a se reverter, provavelmente face ao aumento do abate e finalmente a desaparecer com a normalizarāo do mercado.

Deve-se notar, no entanto, que no curto prazo, os choques de preços influenciam marcantemente as margens de comercialização. Por exemplo, da tabela 8 depreende- se que uma elevação nos preços ao produtor deve reduzir as margens de comercialização, pois os aumentos nos preços ao varejo e útacado são menos que proporcionais. No longo prazo, os efeitos do choque de preços tendem a desaparecer e as margens devem voltar a seus níveis normais.

3.4. Anälise da Decomposição da Variáncia dos Erros de Previsão

As tabelas 11 e 12 mostram a decomposição dos erros de previsão para 48 períodos, para o modelo composto das variáveis preços recebidos pelo produtor paulista (PSP) e mercados varejista (V) e atacadista (A) da cidade de São Paulo. Em função dos resultados observados na anális.e de cau salidade a ordenação utilizada foi PSP, V e A. 
Tabela 11.- Decomposição da variância dos erros de previsão (48 períodos). Ordenação: PSP, $V, A\left({ }^{1}\right)$

\begin{tabular}{|c|c|c|c|c|c|}
\hline \multirow{2}{*}{ Erro } & \multirow{2}{*}{$\begin{array}{l}\text { de previsão } \\
\text { de: }\end{array}$} & \multirow{2}{*}{ no de periodos } & \multicolumn{3}{|c|}{ \% explicada por inovações em } \\
\hline & & & PSP & V & A \\
\hline & \multirow{5}{*}{ PSP } & 01 & 100,00 & 0,00 & 0,00 \\
\hline & & 12 & 94,43 & 4,06 & 1,51 \\
\hline & & 24 & 90,90 & 4,96 & 4,13 \\
\hline & & 36 & 90,76 & 5,25 & 3,98 \\
\hline & & 48 & 90,70 & 5,16 & 4,13 \\
\hline \multirow{10}{*}{1} & \multirow{5}{*}{ v } & 01 & 62,44 & 37,55 & 0,00 \\
\hline & & 12 & 78,30 & 18,96 & 2,73 \\
\hline & & 24 & 77,94 & 17,83 & 4,22 \\
\hline & & 36 & 77,91 & 17,86 & 4,23 \\
\hline & & 48 & 78,28 & 17,48 & 4,24 \\
\hline & \multirow{5}{*}{ A } & 01 & 45,57 & 4,96 & 49,46 \\
\hline & & 12 & 68,33 & 5,44 & 26,23 \\
\hline & & 24 & 71,46 & 6,53 & 22,01 \\
\hline & & 36 & 71,03 & 7,26 & 21,72 \\
\hline & & 48 & 71,67 & 7,13 & 21,20 \\
\hline
\end{tabular}

(1) PSP, V e A referem-se aos preços recebidos pelos produtores paulistas e mercados varejista e atacadista da cidade de São Paulo, respectivamente. 
Tabela 12. - Decomposição da variāncia dos erros de previsão (48 períodos). ordenação: A, V, PSP $\left(^{1}\right)$

\begin{tabular}{|c|c|c|c|c|}
\hline \multirow{2}{*}{$\begin{array}{c}\text { Erro de previsão } \\
\text { de: }\end{array}$} & \multirow{2}{*}{ no de períodos } & \multicolumn{3}{|c|}{ \% explicada por inovações em } \\
\hline & & $A$ & v & PSP \\
\hline \multirow{5}{*}{ A } & 01 & 100,00 & 0,00 & 0,00 \\
\hline & 12 & 75,11 & 10,22 & 14,67 \\
\hline & 24 & 64,25 & 17,30 & 18,46 \\
\hline & 36 & 64,02 & 17,55 & 18,42 \\
\hline & 48 & 63,28 & 17,98 & 18,74 \\
\hline \multirow{5}{*}{ V } & 01 & 44,88 & 55,11 & 0,00 \\
\hline & 12 & 44,90 & 40,96 & 14,14 \\
\hline & 24 & 42,04 & 39,94 & 18,02 \\
\hline & 36 & 42,64 & 39,62 & 17,73 \\
\hline & 48 & 42,31 & 39,45 & 18,24 \\
\hline \multirow{5}{*}{ PSP } & 01 & 45,57 & 20,72 & 33,70 \\
\hline & 12 & 37,71 & 18,33 & 43,96 \\
\hline & 24 & 35,43 & 18,66 & 45,91 \\
\hline & 36 & 37,05 & 19,72 & 43,23 \\
\hline & 48 & 36,46 & 20,11 & 43,42 \\
\hline
\end{tabular}

( 1 ) A, V e PSP referem-se aos preços recebidos pelos mercados atacadista e varejista da cidade de são paulo e pelos produtores paulistas, respectivamente. 
Observa-se na tabela 11 que $100 \%$ da variáncia dos erros de previsão no primeiro período em PSP se deve a choques na própria variável e nos demais periodos a variància dos erros de previsão é, em sua maior parte, explicada tambëm por inovações em PSP. Esse resultado sugere que PSP seja uma variável essencialmente exögena, não afetada significativamente pelas variàveis $V$ e $A$.

No caso de erro de previsão de $V, 62,4 \%$ da variância desse erro, no primeiro período, são devidos a PSP e $37,56 \%$ a V. Com relação aos erros de previsão da A, 45,57\% da variäncia desses erros, no primeiro perfodo, se deve a PSP, $4,96 \%$ a V e $49,47 \%$ a A. Tanto no caso de erros de previ säo de PSP, como de $V$ e A, a parcela da variáncia dos erros devida à própria variável diminui ao longo dosperíodos analisados, enquanto que a parcela devida às demais variàveis aumenta. Em períodos mais longos a maior parte da variáncia dos erros de previsão é explicada pela variävel PSP. No caso de erros de A, a parcela de variancia devida a PSP cresce de $45,57 \%$ no primeiro período para $71,67 \%$ no quadragésimo oitavo período.

Na tabela 12 estão representados os resultados da decomposição de variāncia obtidos de uma alteração na ordem dos preços, a qual passou a ser A, V, PSP. Observa-se que os resultados se alteraram de maneira significativa; a importància de inovações em PSP diminuiu, enquanto a im- 
portāncia de inovaçōes em $A$ e em $V$ aumentou. Dessa forma, podemos admitir que PSP nào é uma variável essencialmente exögena, como jä verificado na anälise de causalidade.

os efeitos de choques e a decomposição dos erros de previsão para os modelos que utilizam produtores de outros Estados são apresentados no apẽndice 2.

\subsection{Anälise das Margens de Comercializaçāo}

No càlculo de margens de comercialização é necessäria a transformaçāo do preço ao produtor em quantidade equivalente na fazenda. Nessa transformaçäo säo utilizados os preços dos subprodutos a nível de atacado. No caso da carne bovina hà dificuldade na obtençāo desses preços, os quais não são coletados de forma sistemätica pelas instituições de pesquisa.

Para os anos de 1971, 1972 e 1983 foram calculadas margens correntes de comercialização da carne bovina, utilizando para obtenção dos preços equivalentes na fazenda os trabalhos de D'APICE PAEZ(1978) para os anos de 1971 e 1972 e o trabalho de CANTO (1986) para o ano de 123.3. Para esses trēs anos foram calculadas margens correntes abso lutas de comercialização (total, do atacado e do varejo) e margens porcentuais de comercialização (total, do atacado,do varejo e parcela do produtorl. 
Para anälise da sērie 1971/87 foram calculadas margens correntes de comercialização sem utilizar os preços equivalentes na fazenda, devido a dificuldade de obtenção dos preços dos subprodutos a nível de atacado. Essas margens foram, então, denominadas de parcelas absolutas de comercialização de carne bovina (total, do varejo e do atacado) e parcelas porcentuais de comercializaçāo (total,do produtor, do varejo e do atacadol. Os valores dessas parcelas diferem dos valores reais das margens de comercializaçäo, no entanto, será assumido que o comportamento dessas parcelas ao longo do período analisado não deverá diferir do comportamento das margens ${ }^{1}$.

As margens foram calculadas independentemente da existència de causalidade entre os diferentes níveis do mercado em anälise, em termos absolutos em czs/kg de dezembro de 1987 e em termos porcentuais, como proporção do preço do varejo.

Embora o efeito de choques (inovações) nos preços em cada nível de mercado persista por alguns meses, verificou-se que eles tendem a se transmitir instantaneamente de um nível para outro. Diante disso, näo foram calculadas margens de comercialização defasadas, mas apenas margens correntes, as quais se referem a preços recebidos no mesmo més pelos três níveis de mercado. As margens derasadas poderão ser simuladas a partir das margens correntes, com base na anälise de inovações.

1 Baseando-se nos trabalhos de D'APICE PAEZ(1978) e de CANTO(1986), assumiu-se que os subprodutos a nível de atacado valorizaram-se na mesma oroporção que a carne bovina. 
Na anälise e discussäo dos resultados foram utilizadas figuras e tabelas de médias mensais e anuais dos diferentes tipos de margens calculadas. Isto é, foram analisados o comportamento mensal das margens e a sua tendēncia ao longo dos anos.

3.5.1. Parcelas de comercialização interanuais

As parcelas porcentuais de comercialização de carne bovina, médias anuais de 1971 a 1987 , obtidas pelos mercados varejista e atacadista da cidade de são paulo e produtores do Estado de São Paulo estão representadas na tabeia 13 e nas figuras 12 a 16 . As parcelas absolutas de comercialização de carne bovina, em $C z S / k g$, mëdias ranuais de 1971 a 1987 estão representadas na tabela 62 e figuras 35 e 36 (apèndice 3).

Na figura 17 e tabela 14 estão representados os preços médios anuais reais recebidos pelos mercados produtor paulista, varejista e atacadista da cidade de sáo Pau10, respectivamente. Nas figuras 51,52 e 53 (apêndice 3) estão representados os preços mëdios mensais reais recebidos pelos produtores paulistas e mercados varejista e atacadista. Verifica-se que os preços médios anuais reais apresentam comportamento semelhante nos três níveis de mercado. 
parcela total de comercialização atingiu valor mäximo no ano de $1982(50,04 \%)$ e valor mínimo em 1974 (34,20\%). Seus valores decrescem de 1971 a 1974, recuperaram-se em 1975 e tornam a decrescer até 1979, quando passam a crescer, atingindo valor mäximo. De 1982 a 1986 a parcela total é novamente decrescente e aumenta em 1987.0bserva-se, ainda, que a parcela total de comercialização não apresenta tendência.

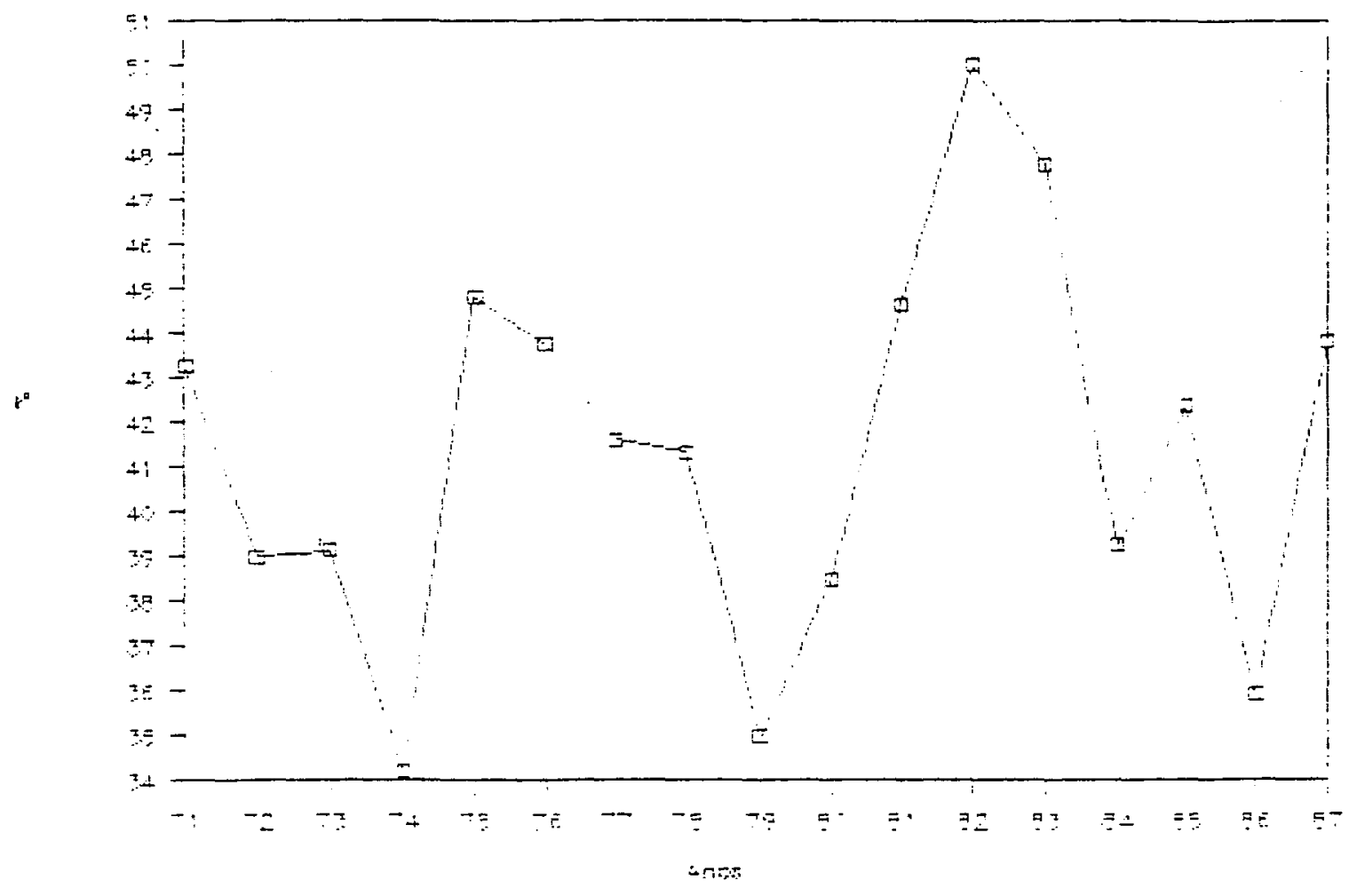

Figura i2.-0arceia porcentual sotal te comercializacäo ce carne bovina. Mëcias anuais (1997/87). 
Tabela 13.- Parcelas porcentuais de comercialização de carne bovina. Médias anuais $(1971 / 87)\left({ }^{1}\right)$, em $\%$.

\begin{tabular}{|c|c|c|c|c|c|}
\hline Meses & de & $\begin{array}{l}\text { Parcela total } \\
\text { Comercialização }\end{array}$ & $\begin{array}{l}\text { Parcela do } \\
\text { Produtor }\end{array}$ & $\begin{array}{l}\text { Parcela do } \\
\text { - Varejo }\end{array}$ & $\begin{array}{l}\text { Parcela do } \\
\text { Atacado }\end{array}$ \\
\hline 1971 & & 43,28 & 56,72 & 35,67 & 7,61 \\
\hline 1972 & & 39,00 & 61,00 & 37,95 & 1,05 \\
\hline 1973 & & 39,16 & 60,84 & 46,65 & $-7,49$ \\
\hline 1974 & & 34,20 & 65,81 & 34,36 & $-0,17$ \\
\hline 1975 & & 44,85 & 55,15 & 36,39 & 8,45 \\
\hline 1976 & & 43,76 & 56,23 & 34,55 & 9,22 \\
\hline 1977 & & 41,62 & 58,38 & 39,84 & 1,77 \\
\hline 1978 & & 41,34 & 58,66 & 43,61 & $-2,27$ \\
\hline 1979 & & 34,97 & 65,03 & 30,57 & 4,40 \\
\hline 1980 & & 38,51 & 61,49 & 31,53 & 6,98 \\
\hline 1981 & & 44,67 & 55,34 & 31,62 & 12,05 \\
\hline 1982 & $:$ & 50,04 & 49,96 & 35,42 & 14,63 \\
\hline 1983 & & 47,79 & 52,21 & 36,03 & 11,75 \\
\hline 1984 & & 39,26 & 60,74 & 33,59 & 5,66 \\
\hline 1985 & & 42,38 & 57,61 & 31,76 & 10,62 \\
\hline 1986 & & 35,93 & 64,07 & 24,14 & 11,79 \\
\hline 1987 & & 43,83 & 56,17 & 30,83 & 12,99 \\
\hline
\end{tabular}

(') Produtor do Estado de São Paulo e mercados varejista e atacadista da cidade de São Paulo. 
A parcela porcentual do varejo (figura 13) é elevada nos anos de 1973 e $1978(46,65 \%$ e 43,6) , respectivamente), quando atinge valores mäximos. Seu valor è mínimo em $1986(24,14 \%)$. Observa-se tendéncia decrescente da parcela porcentual do varejo ao longo do período analisado, poss velmente devido a maior participação dos supermercados.

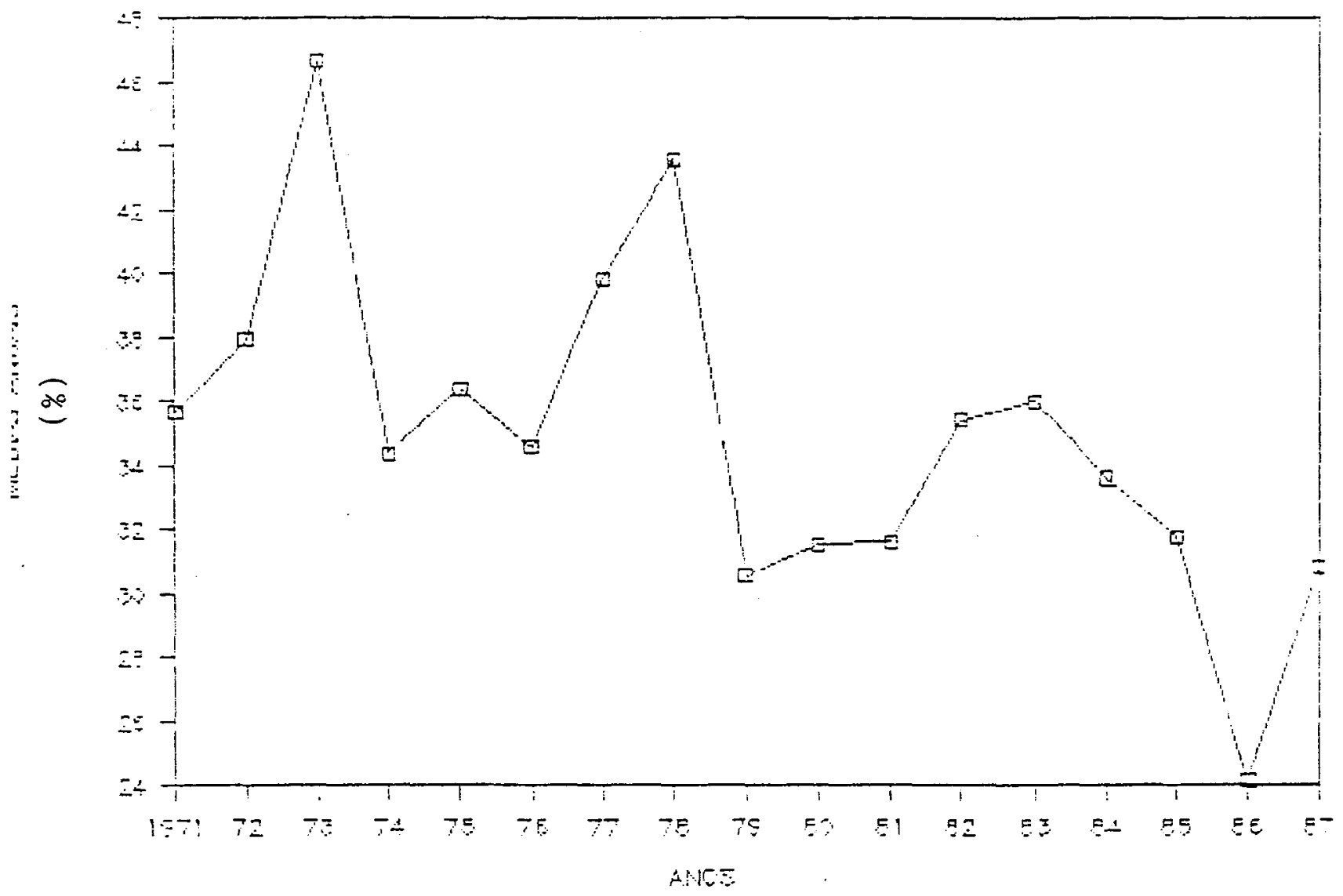

Figura 13.- Parcela porcentual do varejo. Médias anuais (1971/87).

A parcela porcentual do atacado (figura apresenta valor mäximo no ano de $1982(14,63 \%)$ e nos anos de 1973, 1974 e 1978 seus valores são mínimos e negativos $(-7,49 \%,-2,27 \%$ e $-0,17 \%$, respectivamente). Levando-se em conta que essas parcelas foram calculadas sem descontar os 
valores dos subprodutos, os valores reais das margens podem näo ser negativos, porēm serão também valores baixos. Esses dados sugerem que nos anos de 1973 , 1974 e 1978 os agentes atacadistas trabalharam com margens muito pequenas ou mesmo com prejuízo. Da figura 14, verifica-se que a parcela porcen tual do atacado apresenta tendència crescente.

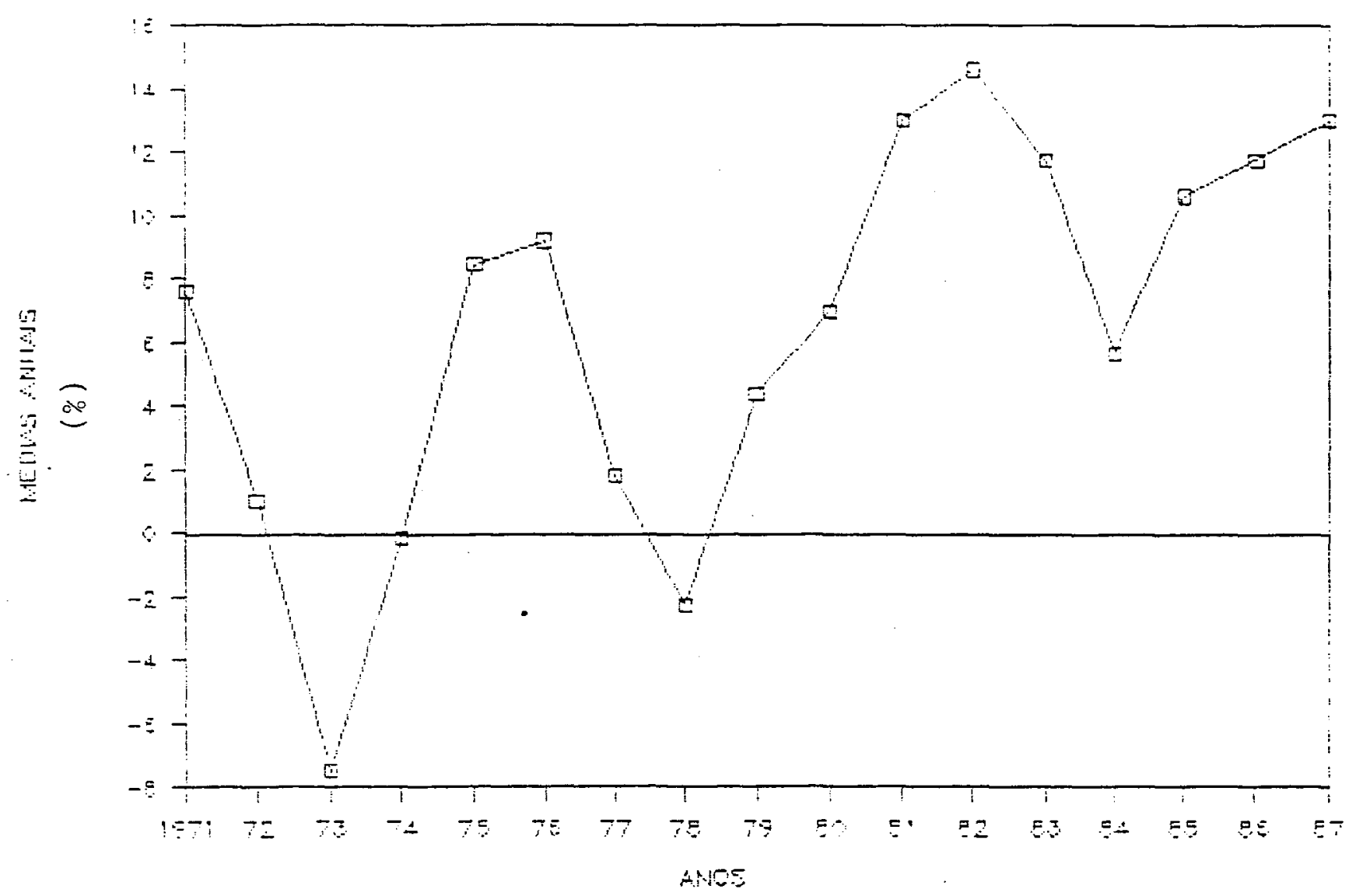

Figura 14. - Parcela porcentual do atacado. Médias anuais (1971/87).

E preciso salientar que no ano de 1973 houve acentuada intervenção governamental no mercado de carne bovina, no sentido de determinação dos preços, tendo sido imposto o programa de limitação dos abates de gado para o pe- 
ríodo de julho a dezembro. Ainda em dezembro de 1973 o governo tabelou os preços do boi gordo a nível de produtor e a partir dessa data a carne bovina foi tabelada tambëm a n vel de atacado; a nível de varejo foram fixadas margens de lucrobruto. Durante todo o ano de 1974 o tabelamento dos preços da carne bovina foi mantido. De agosto a dezembro de 1974 foi estabelecido pelo governo um programa de suspensão de abates em diversos Estados. Em 1975 foi instituído um sistema de abastecimento da região metropolitana de São Paulo através de cotas de carne congelada.

De 1976 a 1979 persistiu o sistema de fixação de cotas de carne congelada e foram fixadas cotas mäximas de abates para diversos Estados. De 1975 a 1978 o governo continuou a controlar os preços da carne bovina no atacado e varejo, porēm atravēs dos "acordos de cavalheiros" (ADABO, $1980)$

Portanto, as pequenas parcelas de comercialização obtidas nos anos destacados podem ser resultantes de polfticas de intervenção governamental; porëm não pode ser descartada a hipōtese de problemas na coleta e manipulação dos dados primários.

Nos anos de 1974,1979 e 1986 a parcela porcentual do produtor atinge seus valores mais elevados $(65,81 \%, 65,03 \%$ e $64,07 \%$, respectivamente) e valores mínimos em 1975 e 1982 (55,15\% e 49,96\%, respectivamente). 
e 14 observa-se que a parcela porcentual do produtor cresce nas fases ascendentes do ciclo de preços reais do boi gordo $(1971 / 74,1977 / 79,1982 / 86)$ e decresce nas fases descendentes desse ciclo $(1974 / 77,1979 / 82)$. A.DABO (1978) obteve resul -

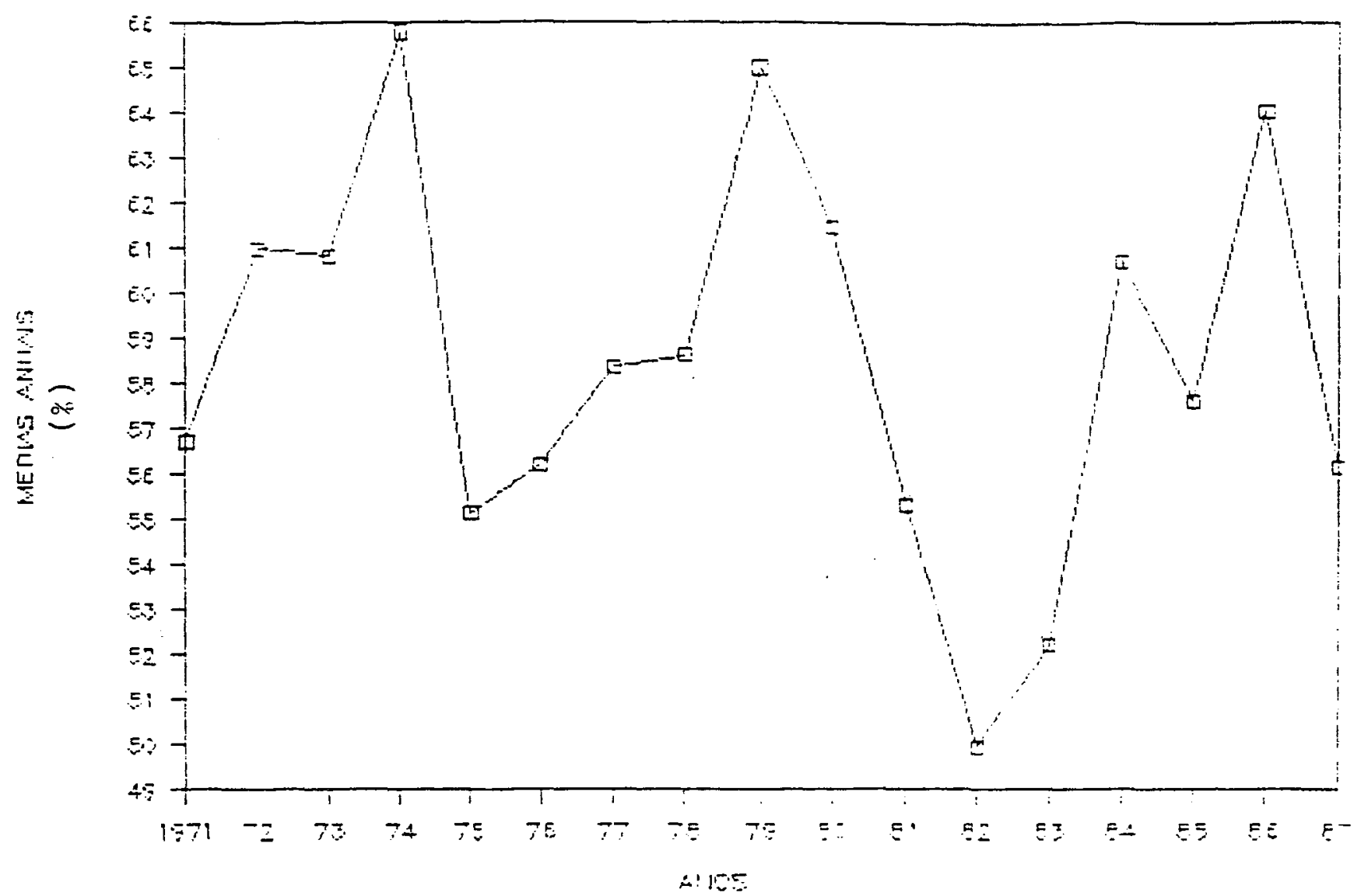

Figura 15.- Parcela porcentual do produtor. Médias anuais $(1971 / 87)$

tado semeltiante, embora os perf́odos de anälise não sejam idēnticos.

$$
\text { Da tabela } 13 \text { e figura } 16 \text { observa-se que as }
$$
parcelas porcentuais do produtor e do atacado apresentam comportamentos opostos. Nas fases ascendentes do ciclo de preços reais do boi gordo a parcela do produtor também cresce, porēm a parcela do atacado decresce; nas fases do ciclo 
em que a parcela do produtor decresce a parcela do atacado cresce. Observa-se, ainda, que as parcelas do produtor e do

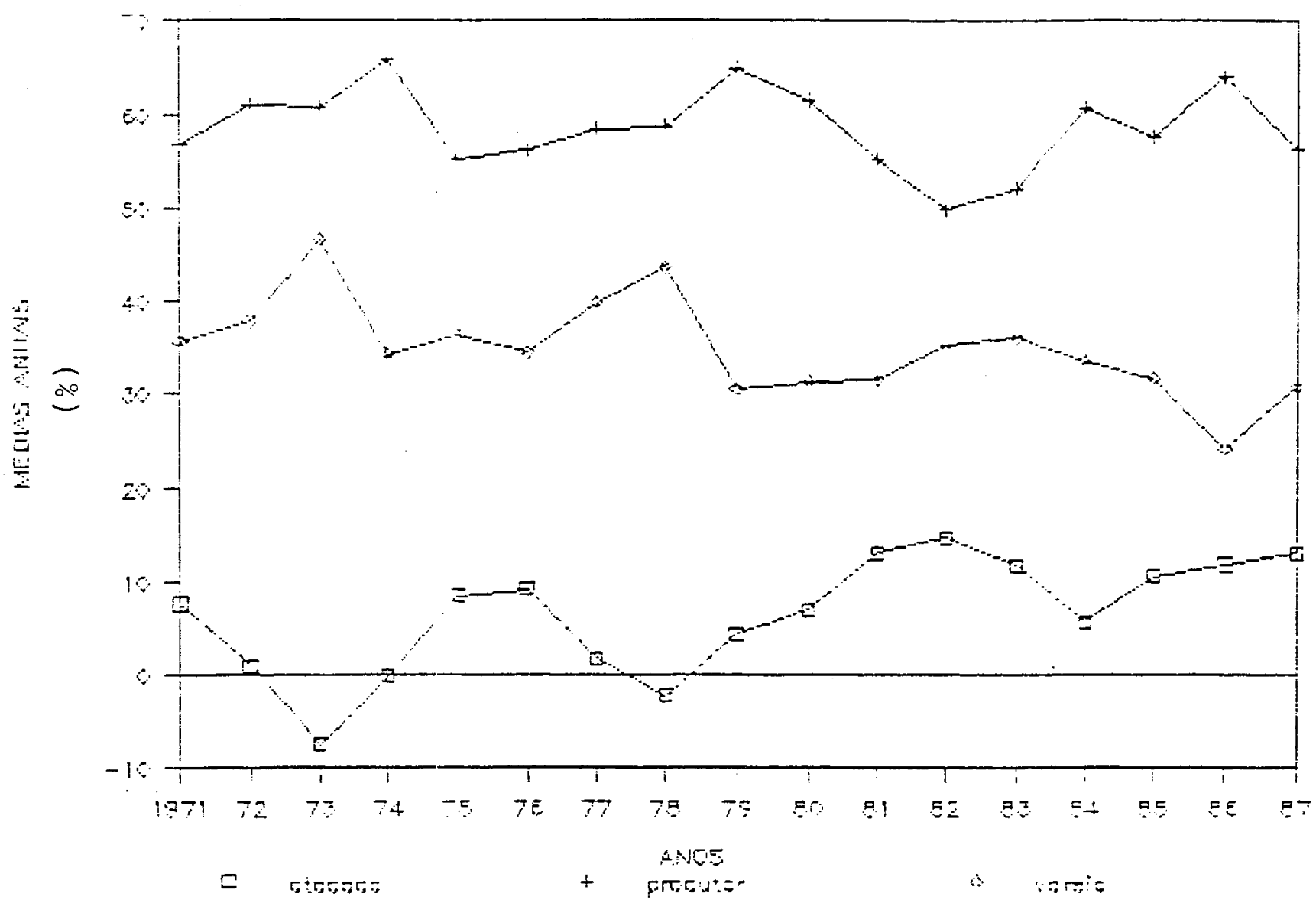

Figura 16.- Parcelas porcentuais de comercialização de carne bovina. Mëdias anuais $(1971 / 87)$.

varejo apresentam comportamentos semelhantes, com exeção dos anos de 19861987 , um provāvel efeito do "Plano Cruzado".

Como ressaltado anteriormente, os equipamentos varejistas responsäveis pela comercialização da carne bovina são os açougues/casas de carne e supermercados. Das figuras 18 a 20 e 37 a 39 do apêndice 3 verifica-se que os supermercados trabalham com parcelas de comercialização sempre inferiores àquelas obtidas pelos açougues/casas de car- 
nes. No entanto, o comportamento das parcelas dos dois tipos de equipamentos varejistas ë semelhante no decorrer de todo - período analisado $(1971 / 87)$. Observa-se, ainda, que nos anos de 1979 e 1986 as quedas ocorridas nas parcelas de comercialização dos supermercados são mais acentuadas do que as quedas nas parcelas dos açougues.

$$
\text { Comparando as figuras } 18,19 \text { e } 20 \text { observa-se }
$$

que os comportamentos das parcelas de comercialização de carne bovina de segunda, de primeira e da média ponderada entre carne de primeira e de segunda são semelhantes, tanto para os açougues como para os supermercados, em todo o período analisado.

Analisando ainda as tabelas. 15 a 17 verifica- se que a parcela porcentual de comercialização dos açougues é mäxima em $1978(46,86 \%)$ enquanto a parcela dos supermercados é mäxima em $1973(40,49 \%)$. A parcela porcentual de comercialização de carne bovina de segunda dos açougues é mäxima em $1978(47,60 \%)$ e dos supermercados em $1973(37,97 \%)$.

No caso da parcela porcentual de comercialização de carne bovina de primeira, as parcelas tanto dos açougues como dos supermercados apresentam valor mäximo em $1973(50,66 \%$ e $45,03 \%$, respectivamente).

VIEIRA \& RENESTO (1977) tambëm encontraram margens de comercialização para os supermercados, em média, inferiores às dos açougues (ver revisão de literatura). 
Tabela 14.- Preços médios anuais reais recebidos pelos mercados produtor paulista, atacadista e varejista da cidade de São Paulo, 1971/87.

\begin{tabular}{|c|c|c|c|}
\hline Ano & Produtores & Atacado & Varejo \\
\hline 1971 & 84,30 & 95,48 & 148,79 \\
\hline 1972 & 91,68 & 93,39 & 150,82 \\
\hline 1973 & 116,89 & 97,75 & 192,42 \\
\hline 1974 & 122,81 & 123,23 & 187,54 \\
\hline 1975 & 103,03 & 118,90 & 187,58 \\
\hline 1976 & 90,76 & 106,67 & 162,68 \\
\hline 1977 & 87,65 & 90,27 & 150,32 \\
\hline 1978 & 114,11 & 109,24 & 193,56 \\
\hline 1979 & 154,11 & 150,54 & 236,65 \\
\hline 1980 & 136,45 & 151,63 & 222,02 \\
\hline 1981 & 96,81 & 119,66 & 174,73 \\
\hline 1982 & 81,76 & 105,84 & 163,59 \\
\hline 1983 & 96,03 & 117,45 & 182,60 \\
\hline 1984 & 109,42 & 119,69 & 180,11 \\
\hline 1985 & 90,83 & 107,23 & 156,97 \\
\hline 1986 & 110,24 & 129,70 & 171,41 \\
\hline 1987 & 100,02 & 122,22 & 178,11 \\
\hline
\end{tabular}


111.

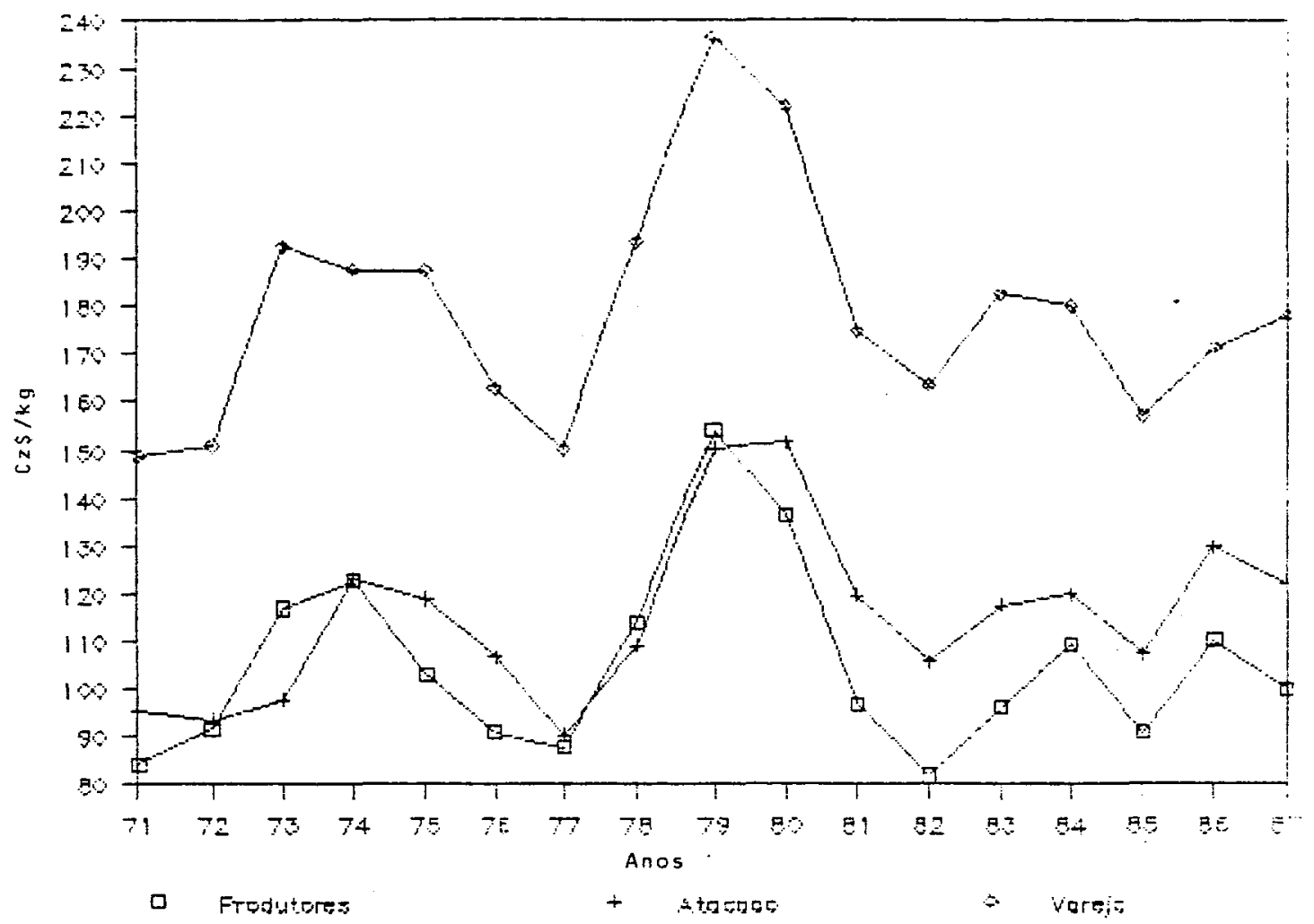

Figura 17.-preços médios anuais reais recetidos pelos produtores paulistas e mercados varejista e atacadista da cidade de sajo paulo, en $c z \$ / k g$,

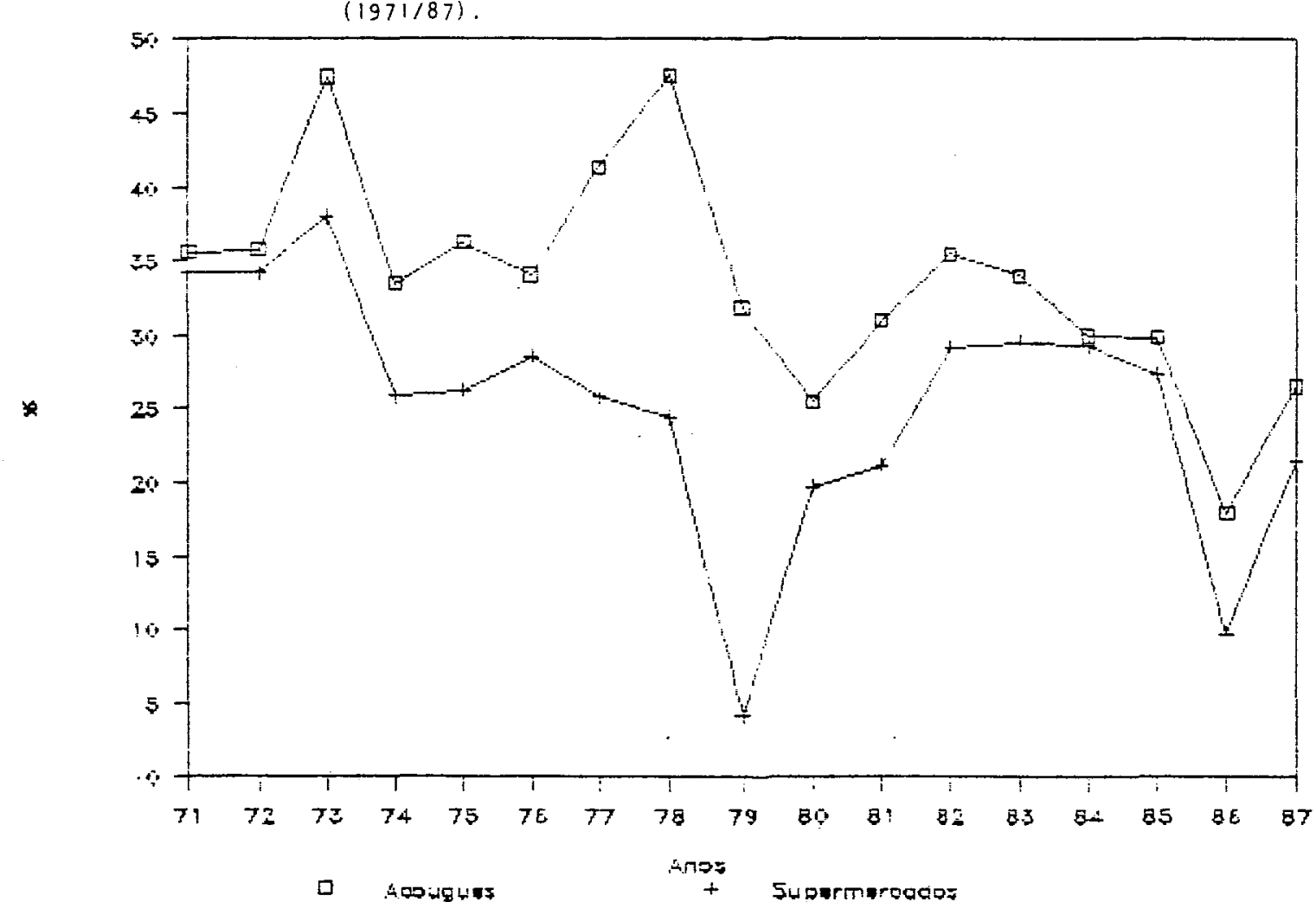

Figura 18.- Parcelas porcentuais de comercializaçäo oe carne bovina de secunda dos açougues e supermercados da cidade de sào paulo. Mädias anuais, $1971 / 87$. 


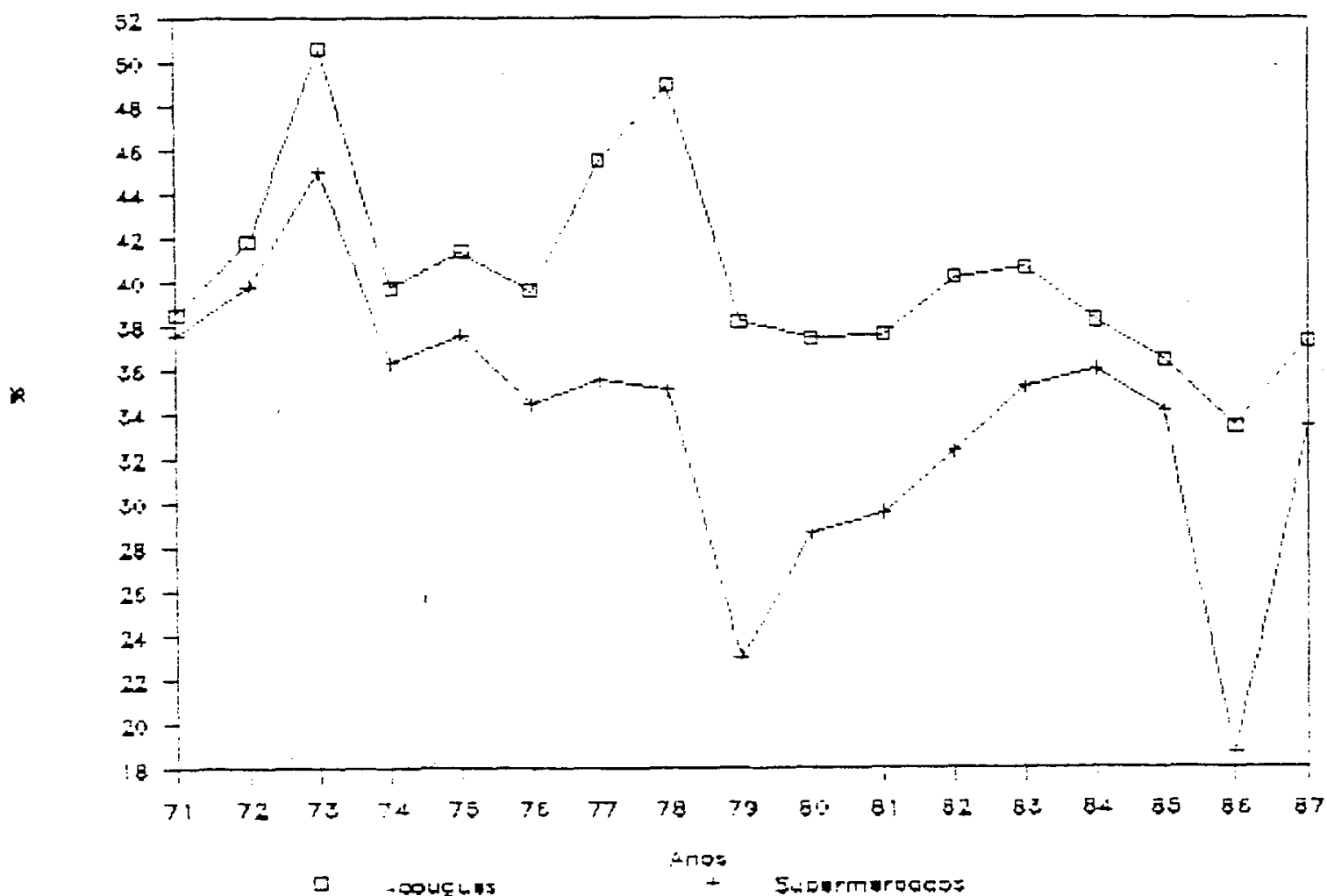

Figura 19. - Parceias percentuais de comercieitizacào oe carne bovina de orimeira dos açougues e suogrmercacos da cidade je são fajio. Médias anuais. 1971,87 .

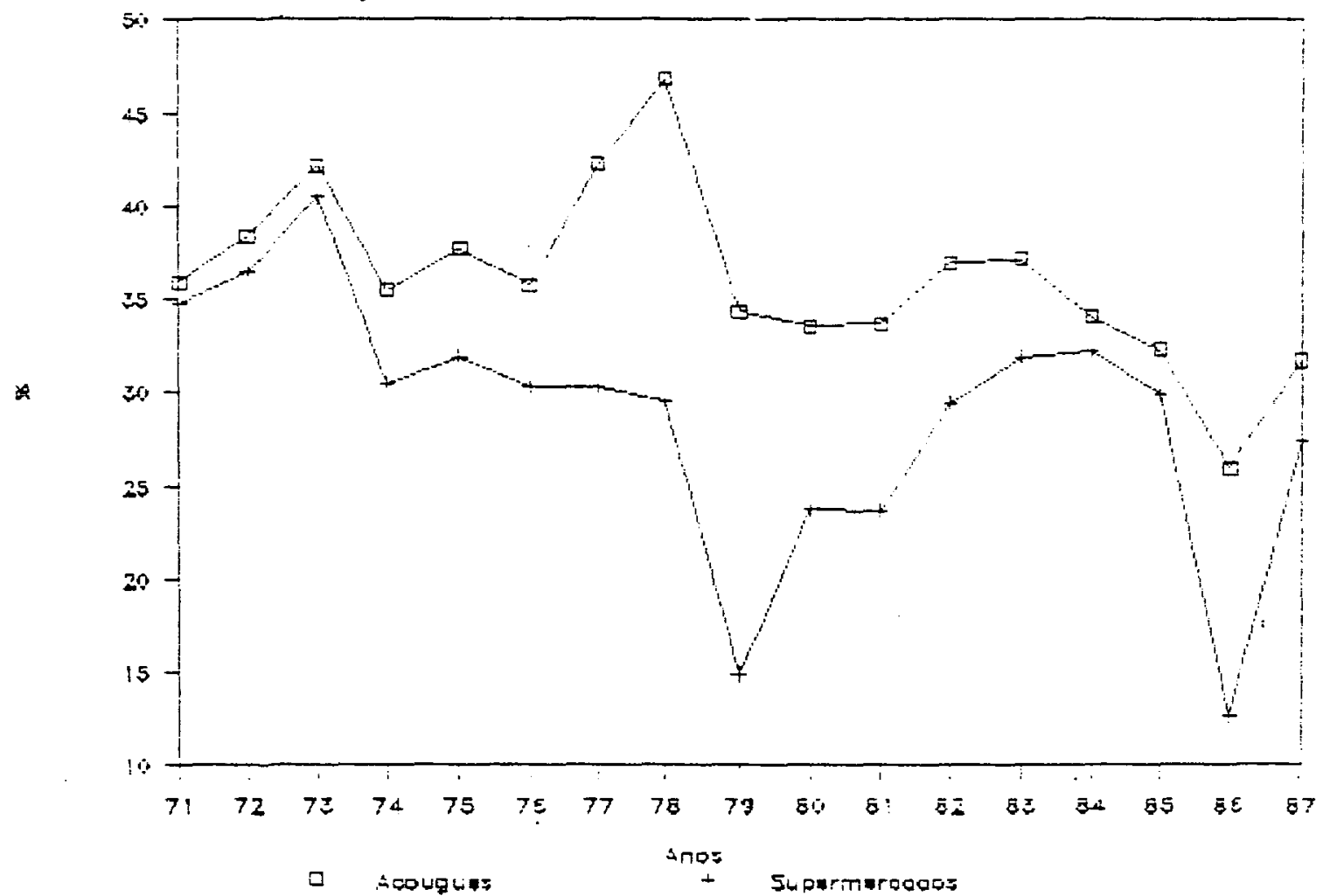

Figura 20. - Parcelas porcentuais je comercializaça de carne bovina imeicia ponceraca entre carne de primetra e oe segunci dos açougues e sudermercados oa cicaje de sảo paulo. Méoias anuais, 1971/87. 
Tabela 15.- Parcelas porcentuais de comercialização de carne bovina( ${ }^{1}$ ) dos açougues e supermercados da cidade de são Paulo, 1971/87. Mëdias anuais.

\begin{tabular}{|c|c|c|}
\hline Anos & Açougues $(\%)$ & Supermercados (\%) \\
\hline 1971 & 35,94 & 34,77 \\
\hline 1972 & 38,39 & 36,50 \\
\hline 1973 & 42,20 & 40,49 \\
\hline 1974 & 35,46 & 30,46 \\
\hline 1975 & 37,68 & 31,91 \\
\hline 1976 & 35,77 & 30,30 \\
\hline 1977 & 42,27 & 30,28 \\
\hline 1978 & 46,86 & 29,59 \\
\hline 1979 & 34,35 & 14,91 \\
\hline 1980 & 33,57 & 23,76 \\
\hline 1981 & 33,70 & 23,66 \\
\hline 1982 & 36,96 & 29,44 \\
\hline 1983 & 37,15 & 31,93 \\
\hline 1984 & 33,99 & 32,24 \\
\hline 1985 & 32,31 & 29,86 \\
\hline 1986 & 25,95 & 12,63 \\
\hline 1987 & 31,76 & 27,42 \\
\hline
\end{tabular}


Tabela 16. - Parcellas porcentuais de comercialização de carne bovina de segunda dos açougues e supermercados da cidade de São Paulo, 1971/87. Médias anuais.

\begin{tabular}{llc}
\hline Anos & Açougues $(\%)$ & Supermercados $(\%)$ \\
\hline 1971 & 35,59 & 34,18 \\
1972 & 35,76 & 34,15 \\
1973 & 47,46 & 37,97 \\
1974 & 33,42 & 25,82 \\
1975 & 36,20 & 26,24 \\
1976 & 34,06 & 28,57 \\
1977 & 41,39 & 25,88 \\
1978 & 47,60 & 24,41 \\
1979 & 31,81 & 4,13 \\
1980 & 25.51 & 19,71 \\
1981 & 30,97 & 21,15 \\
1982 & 35,50 & 29,23 \\
1983 & 34,00 & 29,52 \\
1984 & 29,97 & 29,26 \\
1985 & 29,82 & 27,41 \\
1986 & 17,93 & 9,77 \\
1987 & 26,55 & 21,45 \\
\hline
\end{tabular}


Tabela 17. - Parcelas porcentuais dé comercialização de carne bovina de primeira dos açougues e supermercados da cidade de São Paulo, 1971/87. Médias anuais.

\begin{tabular}{|c|c|c|}
\hline Anos & Açougues $(\%)$ & Supermercados $(\%)$ \\
\hline 1971 & 38,58 & 37,57 \\
\hline 1972 & 41,85 & 39,88 \\
\hline 1973 & 50,66 & 45,03 \\
\hline 1974 & 39,82 & 36,37 \\
\hline 1975 & 41,40 & 37,61 \\
\hline 1976 & 39,65 & 34,45 \\
\hline 1977 & 45,53 & 35,61 \\
\hline 1978 & 48,96 & 35,15 \\
\hline 1979 & 38,24 & 23,09 \\
\hline 1980 & 37,45 & 28,67 \\
\hline 1981 & 37,65 & 29,61 \\
\hline 1982 & 40,19 & 32,36 \\
\hline 1983 & 40,67 & 35,22 \\
\hline 1984 & 38,26 & 36,05 \\
\hline 1985 & 36,48 & 34,13 \\
\hline 1986 & 33,45 & 18,69 \\
\hline 1987 & 37,33 & 33,46 \\
\hline
\end{tabular}


Tabela 18. - Parcelas porcentuais de comercialização de carne bovina. Médias mensais $(1971 / 87)\left(^{1}\right)$, em $\%$.

\begin{tabular}{|c|c|c|c|c|}
\hline Meses & $\begin{array}{l}\text { Parcela total } \\
\text { de Comercialização }\end{array}$ & $\begin{array}{l}\text { Parcela do } \\
\text { Produtor }\end{array}$ & $\begin{array}{c}\text { Parcela do } \\
\text { Varejo }\end{array}$ & $\begin{array}{l}\text { Parcela do } \\
\text { Atacado }\end{array}$ \\
\hline Jane i ro & 42,16 & 54,48 & 36,33 & 5,83 \\
\hline Fevereiro & 43,05 & 53,90 & 35,05 & 7,96 \\
\hline Março & 43,53 & 56,47 & 34,87 & 8,66 \\
\hline Abril & 43,13 & 56,87 & 35,37 & 7,56 \\
\hline Maio & 42,59 & 57,39 & 33,93 & 7,05 \\
\hline Juntio & 43,28 & 56,65 & 39,47 & 6,05 \\
\hline Julho & 43,24 & 56,92 & 35,53 & 7,70 \\
\hline Agos to & 41,39 & 58,73 & 33,87 & 7,52 \\
\hline Setembro & 38,88 & 61,11 & 32,89 & 6,04 \\
\hline Outubro & 38,20 & 61,79 & 33,74 & 4,46 \\
\hline Novembro & 38,00 & 62,00 & 34,91 & 3,09 \\
\hline Dezembro & 39,87 & 60,13 & 35,47 & 4,39 \\
\hline
\end{tabular}

(') Produtor do Estado de São Paulo e mercados varejista e atacadista da cidade de São Paulo. 
3.5.2. Parcelas de comercialização intra-anuais

As parcelas porcentuais médias mensais de comercialização de carne bovina de 1971 a 1987 são representadas na tabela 18 e figuras 21 a 25 e as parcelas absolutas nas tabela 67 e figuras 40 e 41 (apēndice 3).

Da tabela 18 e figura 22 observa-se que a parcela do produtor cresce de junho $(56,65 \%)$ a novembro $(62,00 \%)$, passa a decrescer até fevereiro, aumenta em março e se estabiliza até junho. Desses resultados verifica-se que a parcela do produtor é mais elevada nos meses da entressafra (agosto-dezembro, aproximadamente), quando os preços reais do boi gordo recebidos pelos produtores säo mais elevados (figura 17), enquanto a parcela total de comercialização cai nessa época (tabela 18).

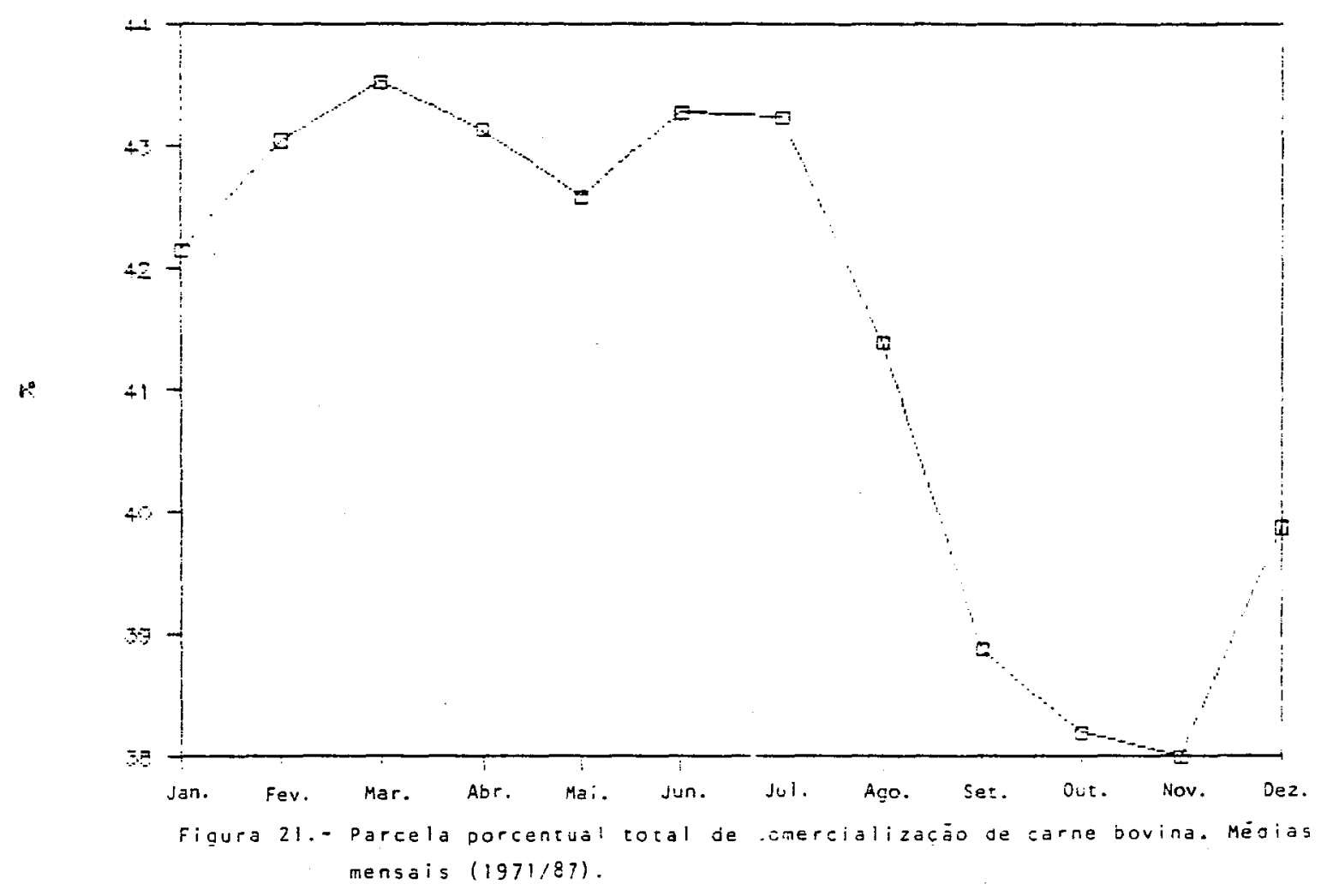


118.

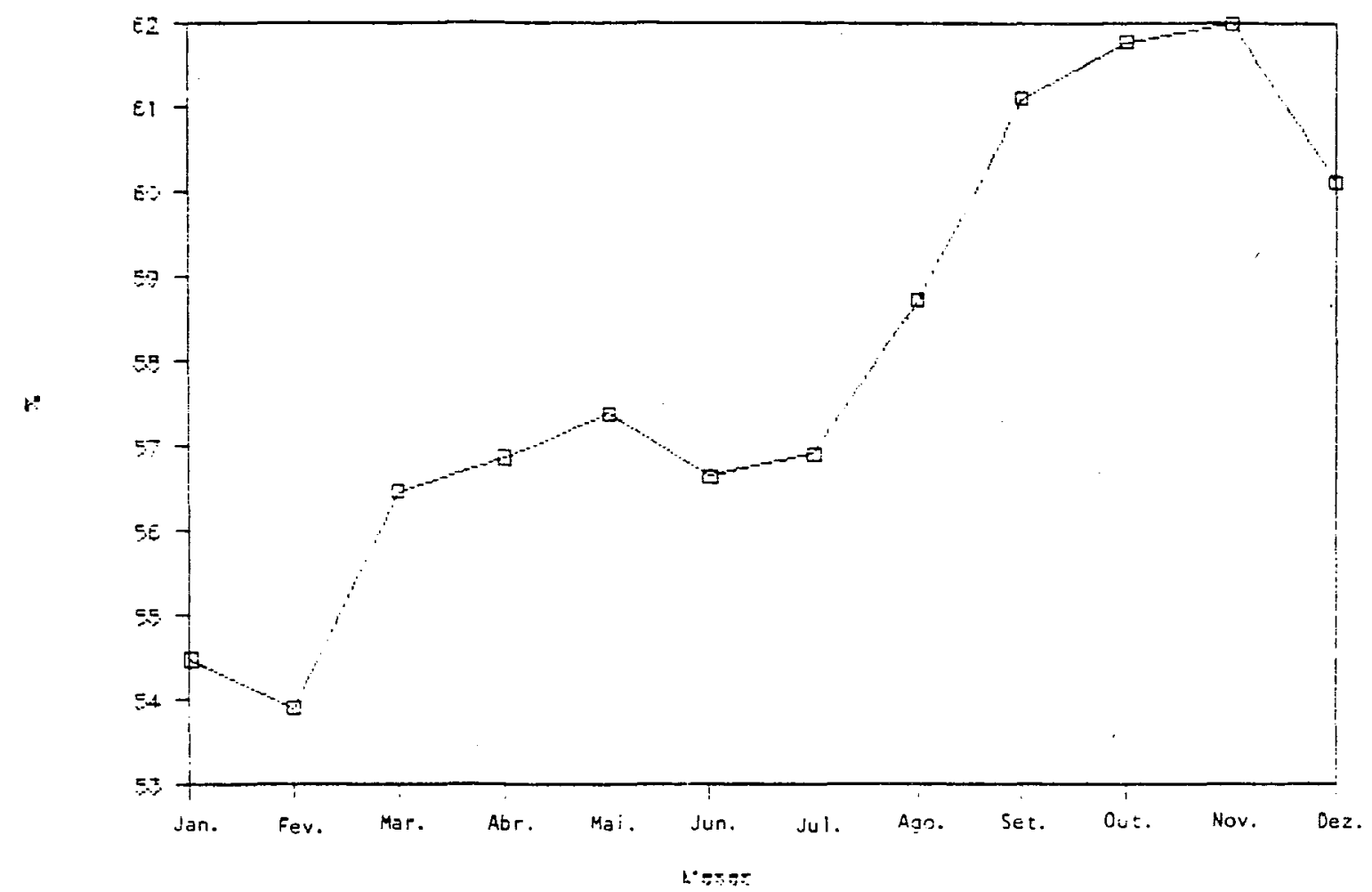

Figura 22.- Parcela porcentuai de producor. Medias mensa is $1971 / 87 !$.

A figura 23 mostra que, ao conträrio da parcela do produtor, a parcela do agente atacadista apresenta os valores mais baixos nos meses da entressafra (principalmente de setembro a janeirol, com valor mínimo em novembro $(3,09 \%)$. o valor mäximo é atingido em março $(8,66 \%)$.

A parcela do varejo atinge valor mäximo em junho $(39,47 \%)$, decresce até setembro (valor mínimo de $32,89 \%$ ), torna a crescer até ofinal da entressafra (janeiro). 


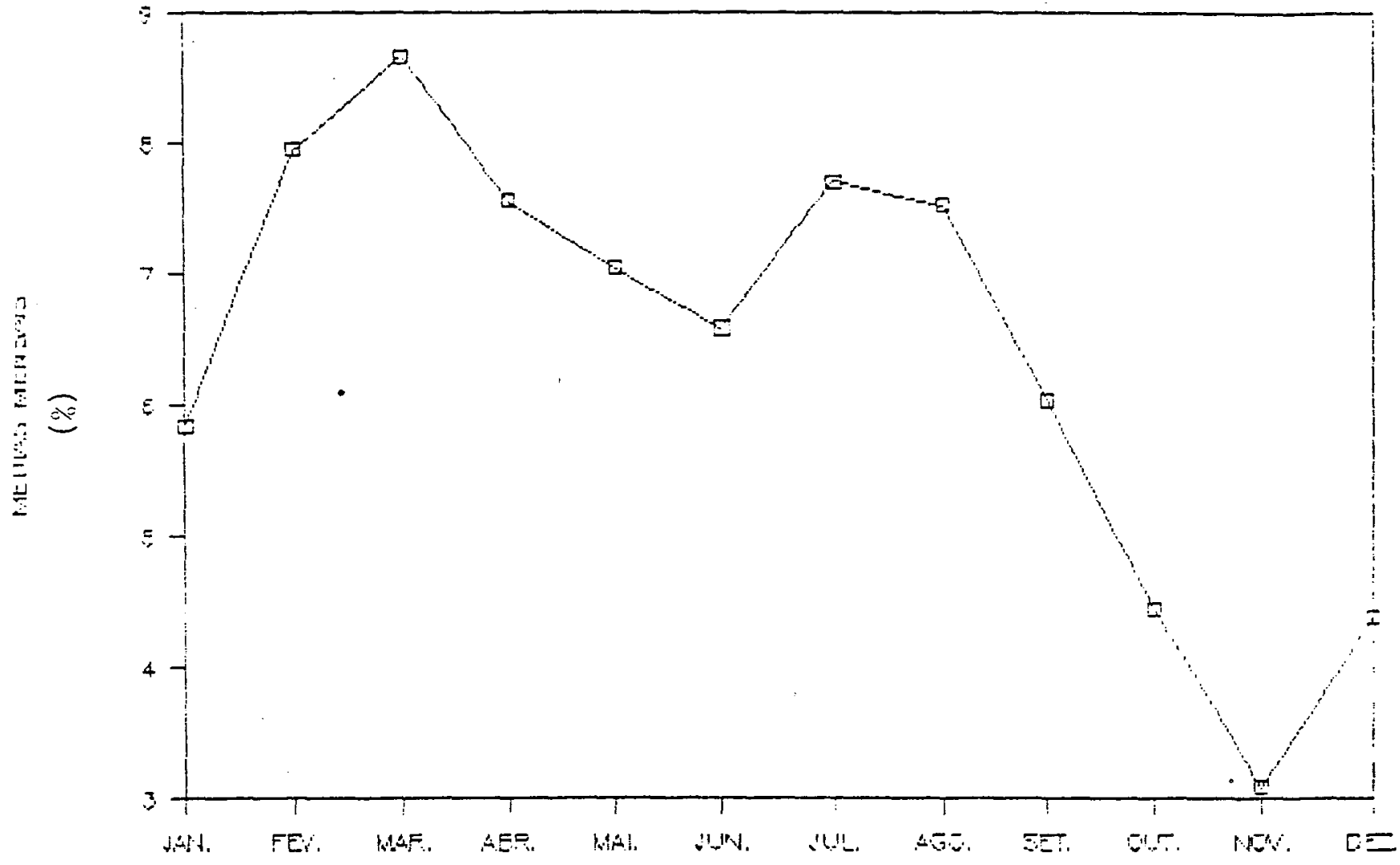

Figura 23. - Parcela percentual do atacado. Médias mensais (1971/87).

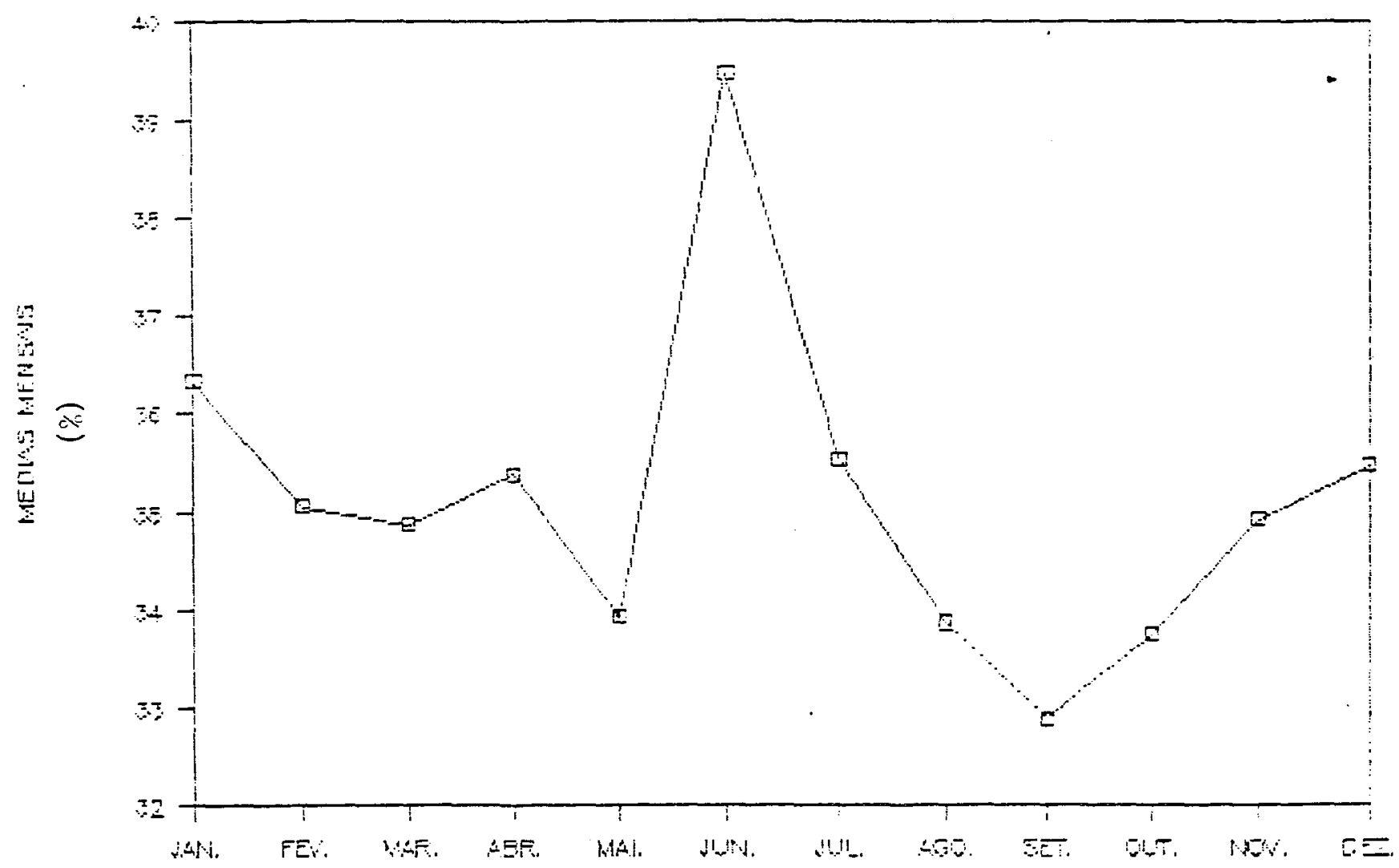

Figura 24.- Parcela porcentual do varejo. Médias mensais (1971/87). 


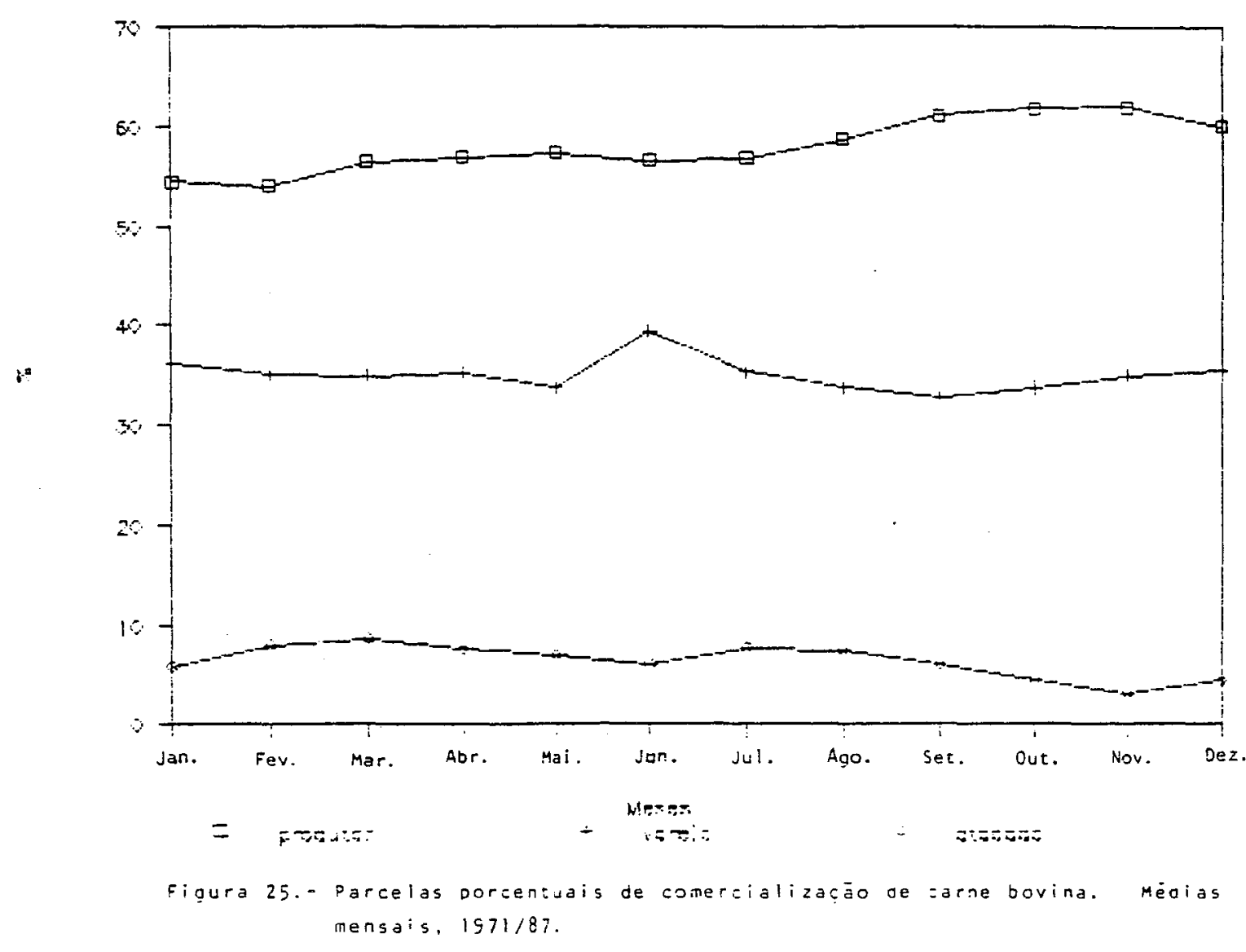

As parcelas porcentuais de comercialização dos açougues/casas de carne e supermercados são apresentadas nas tabelas 19 a 21 e figuras 26 a 28 . Da mesma forma verificada no caso das parcelas interanuais, comparando-se as figuras 26 a 28 observa-se que as parcelas intra-anuais dos supermercados são sempre inferiores às dos açougues, tanto para carne de segunda quanto para carne de primeira.

os valores máximos das parcelas de comercialização de carne bovina de segunda para os açougues e supermercados são atingidos no mês de fevereiro e correspondem a $35,86 \%$ e $28,74 \%$, respectivamente; os valores mínimos são 
atingidos ros meses de setembro $(30,50 \%)$ e outubro $(19,33 \%)$, respectivamente.

No caso das parcelas de comercialização de carne de primeira dos açougues e supermercados, os valores mäximos são atingidos nos meses de dezembro (41,52\%) e junho $(36,51 \%)$, respectivamente. Os valores mínimos.ocorrem nos meses de setembro $(38,92 \%)$ e dezembro $(28,58 \%)$, respectivamente.

Ao longo do ano, o comportamento das parcelas dos açougues e dos supermercados é semelhante.

As parcelas absolutas de comercialização dos açougues e supermercados são representadas nas tabelas 67 a 69 e figuras 42 a 44 .

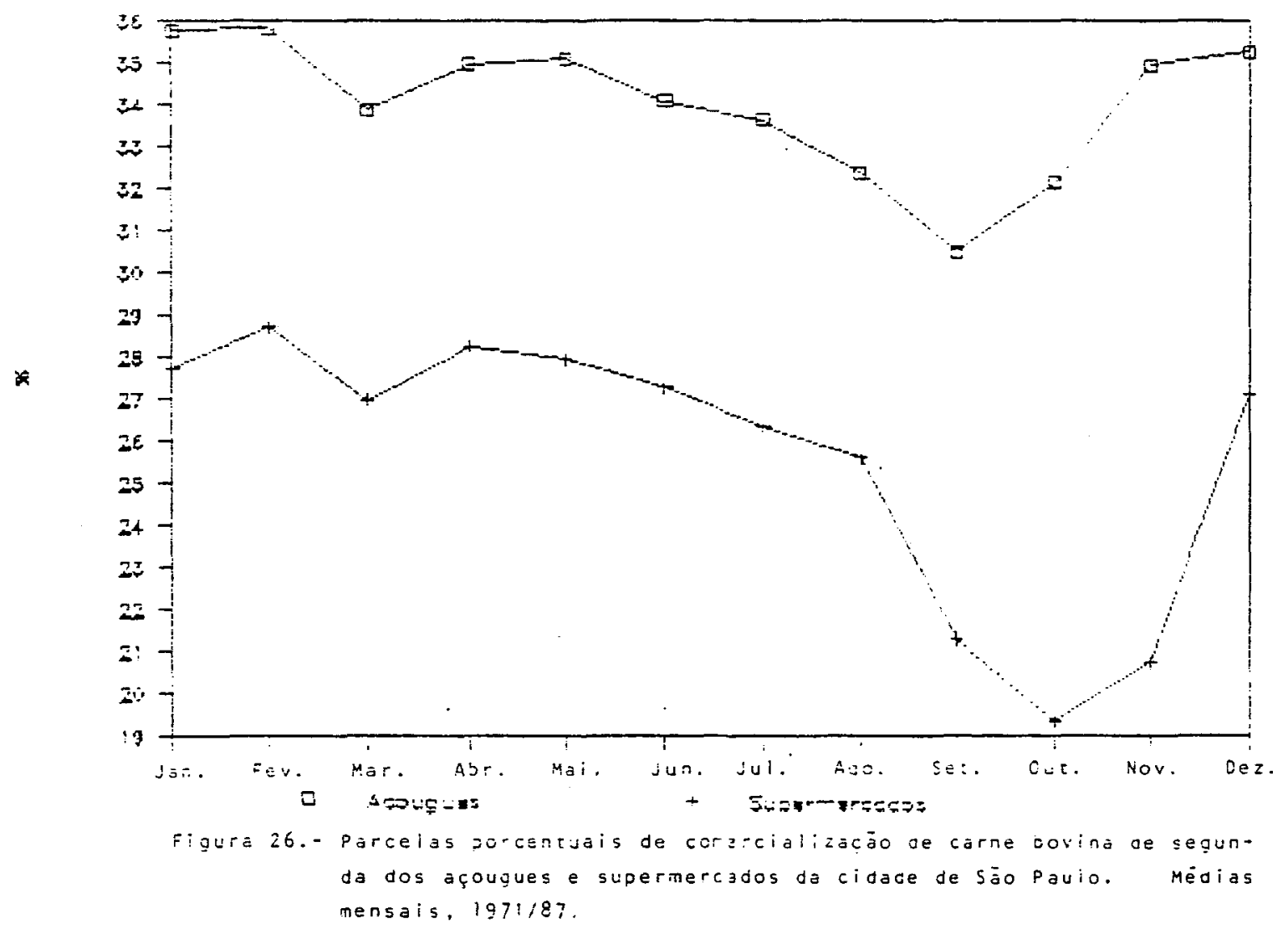


122.

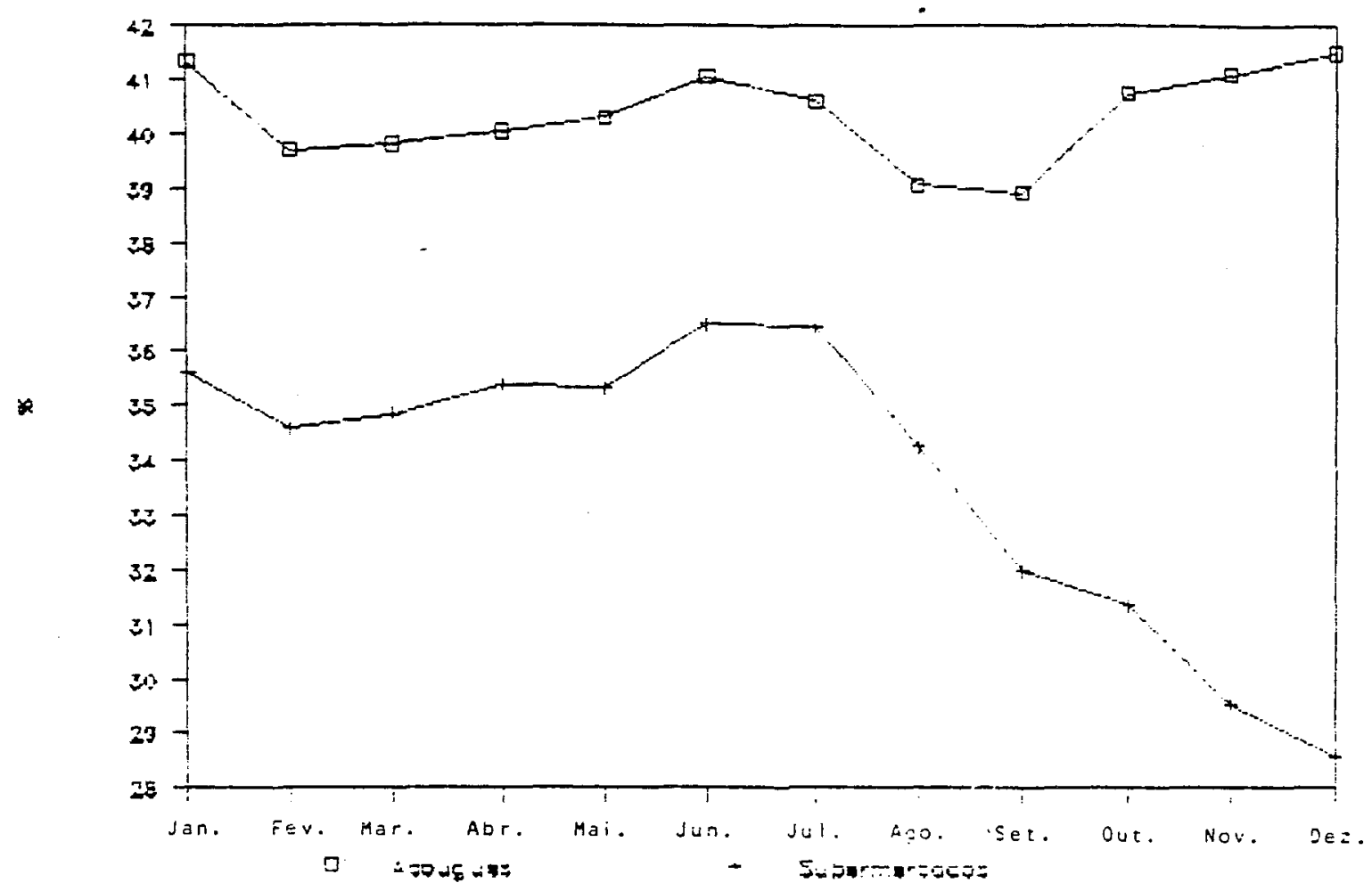

Figura 27. Parcelas porcentuais de comerciaizizäo je carne bovina de orimeira dos açougues e supermercades da ciace ce säo pauio. Médias mensais, i971/87.

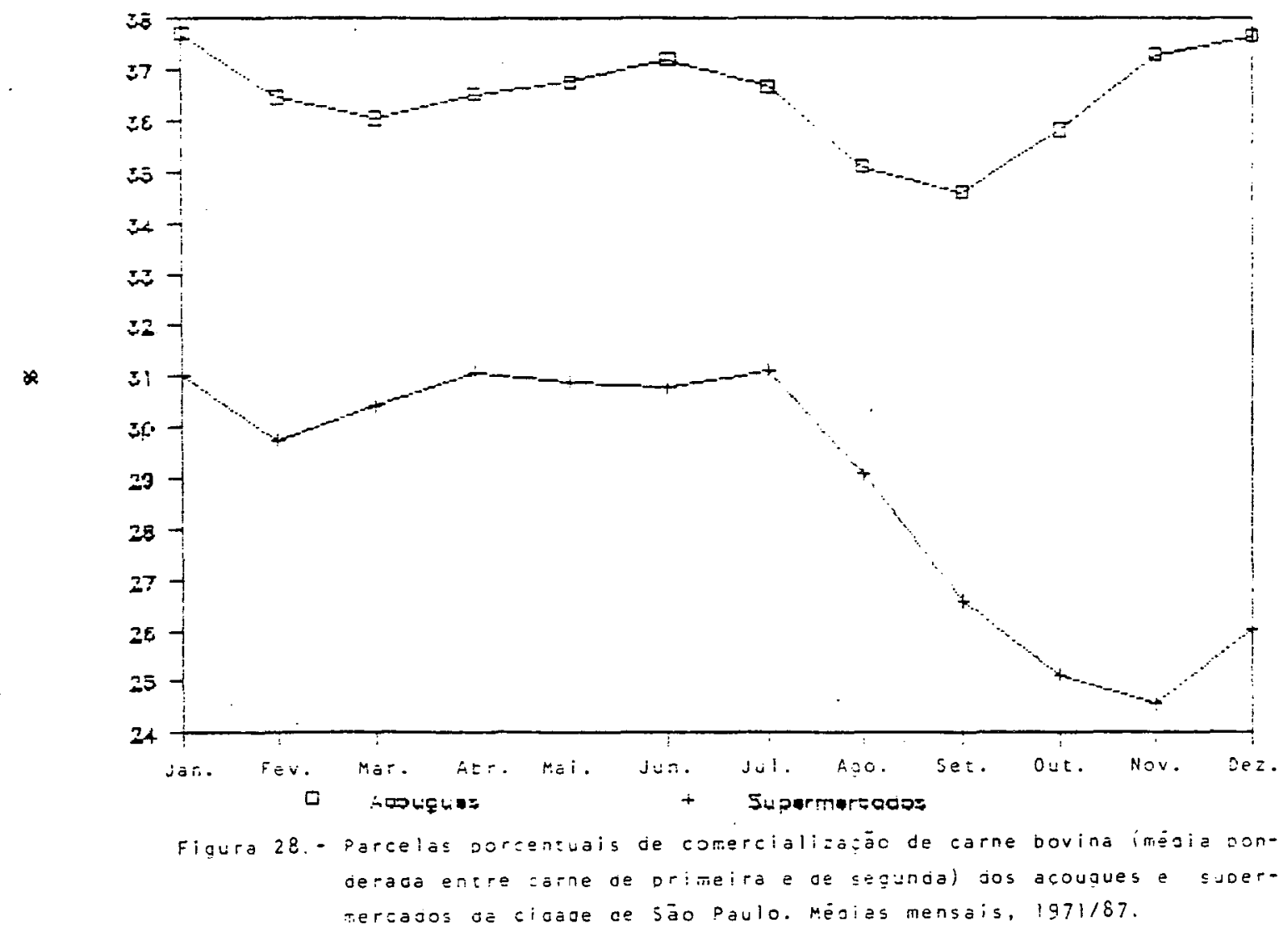


Tabela 19.- Parcelas porcentuais de comercialização de carne bovina $\left({ }^{1}\right)$ dos açougues e supermercados da cidade de São Paulo, 1971/87. Médias mensais.

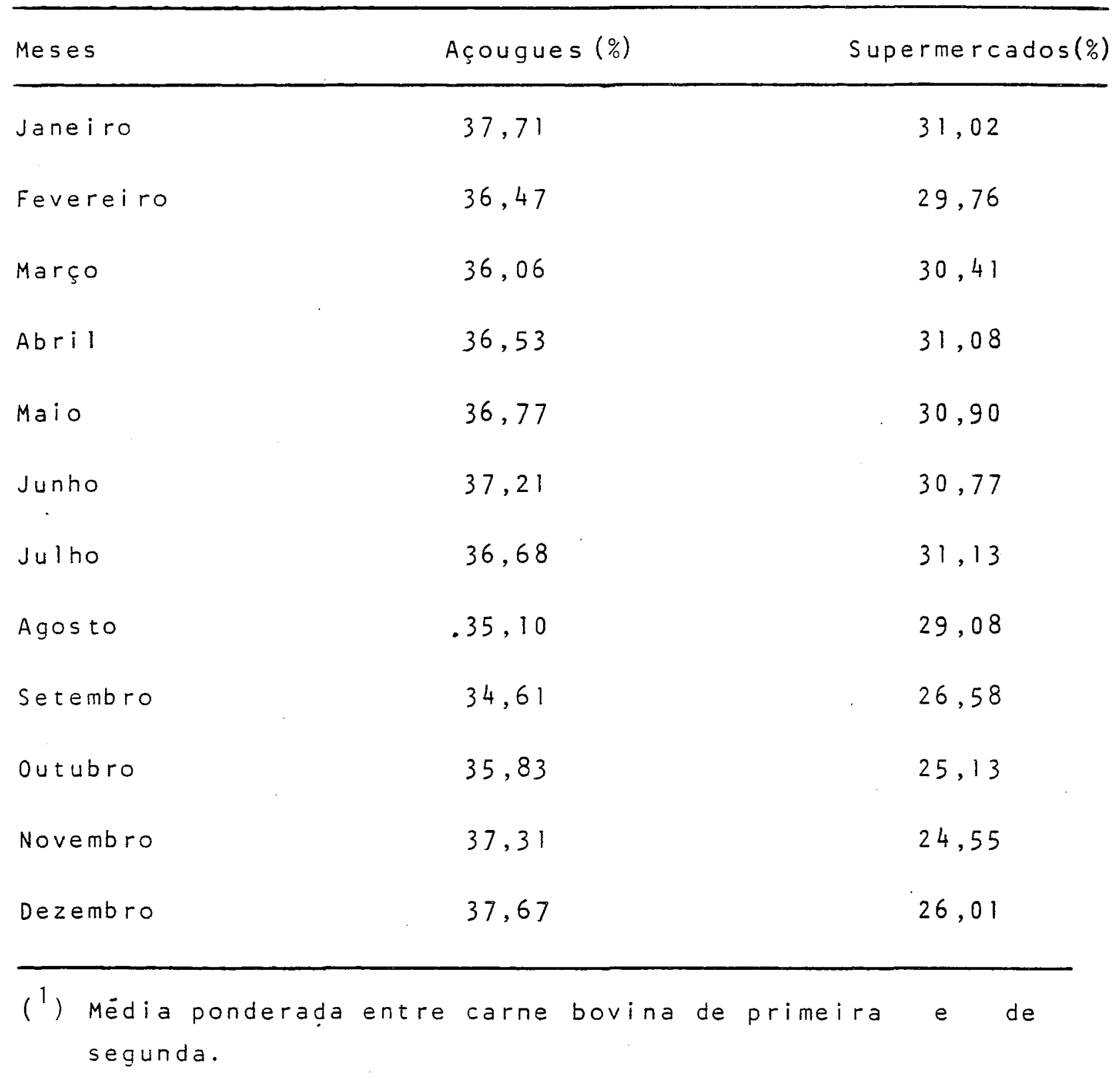


Tabela, 20. - Parcelas porcentuais de comercialização de carne bovina de segunda dos açougues e supermercados da cidade de São Paulo, 1971/87. Médias mensais.

\begin{tabular}{lcc}
\hline Meses & Açougues (\%) & Supermercados $(\%)$ \\
\hline Janeiro & 35,79 & 27,74 \\
Fevereiro & 35,86 & 28,74 \\
Março & 33,89 & 26,98 \\
Abril & 34,98 & 28,25 \\
Maio & 35,13 & 27,97 \\
Junho & 34,09 & 27,30 \\
Julho & 33,65 & 26,38 \\
Agosto & 32,39 & 25,63 \\
Setembro & 30,50 & 21,30 \\
Nutubro & 32,15 & 20,73
\end{tabular}


Tabela 21,- Parcelas porcentuais de comercialização de carne bovina de primeira, dos açougues e supermercados da cidade de são Paulo, 1971/87. Médias mensais.

\begin{tabular}{lcc}
\hline Meses & Açougues(\%) & Supermercados (\%) \\
\hline Janeiro & 41,35 & 35,61 \\
Fevereiro & 39,70 & 34,60 \\
Março & 39,83 & 34,85 \\
Abril & 40,06 & 35,39 \\
Maio & 40,32 & 35,33 \\
Junho & 41,08 & 36,51 \\
Julho & 40,64 & 36,48 \\
Agosto & 39,09 & 34,27 \\
Setembro & 48,92 & 31,98 \\
Outubro & 40,76 & 31,34 \\
Novembro & 41,13 & 29,52 \\
\hline
\end{tabular}


3.5.3. Margens de comercialização em 1971,1972 e 1983

As margens de comercialização para os anos de 1971, 1972 e 1983 estão representadas nas tabelas 22 a 24 e nas figuras 29 a 31 (margens porcentuais) e figuras 45 a 47 do apēndice 3 (margens absolutas).

Nos anos de 1971, 1972 e 1983 as margens (porcentuais e absolutas) do atacado e do varejo apresentaram comportamentos opostos, ao longo dos meses, embora as magnitudes dessas margens tenham sido significativamente diferentes em cada ano.

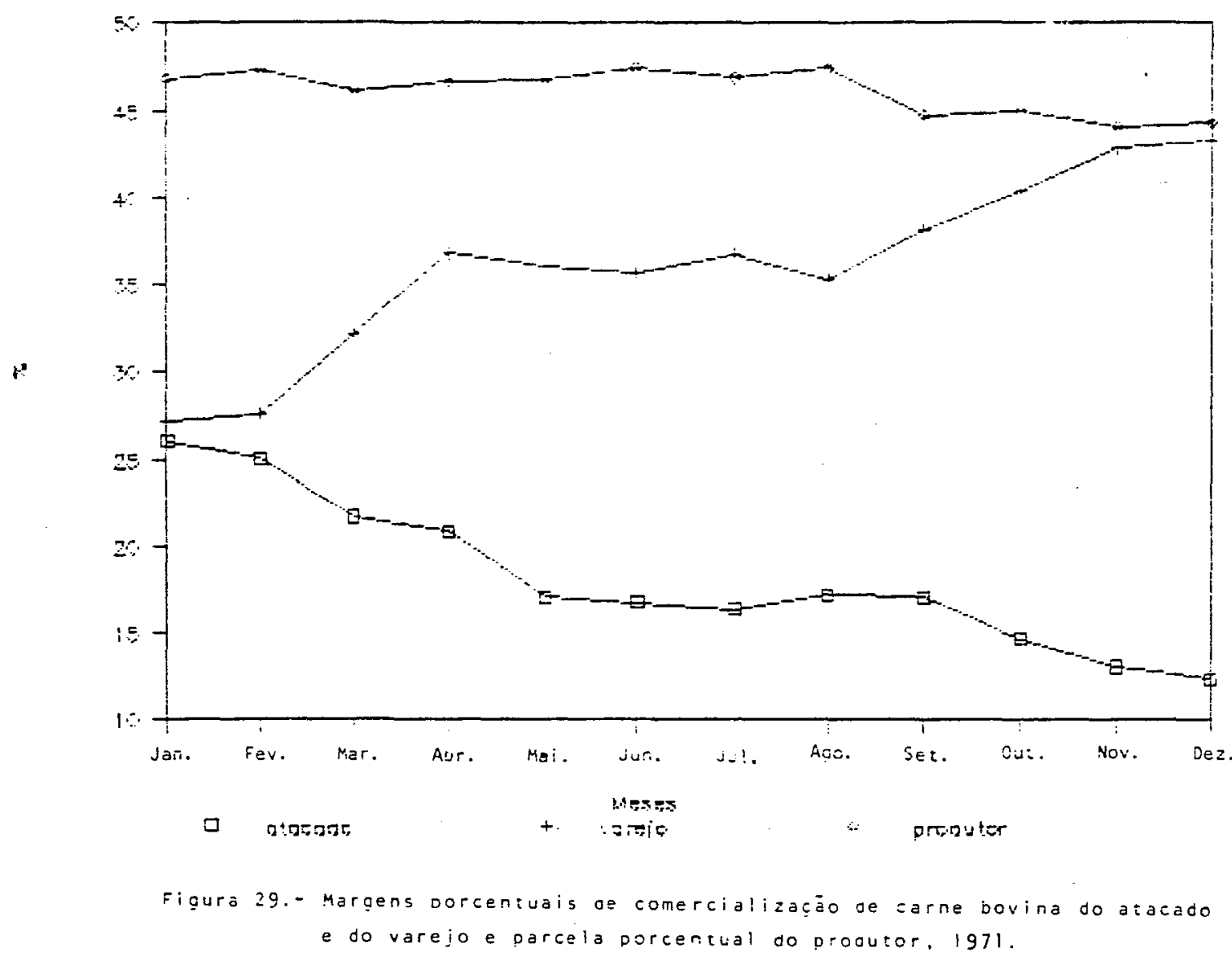




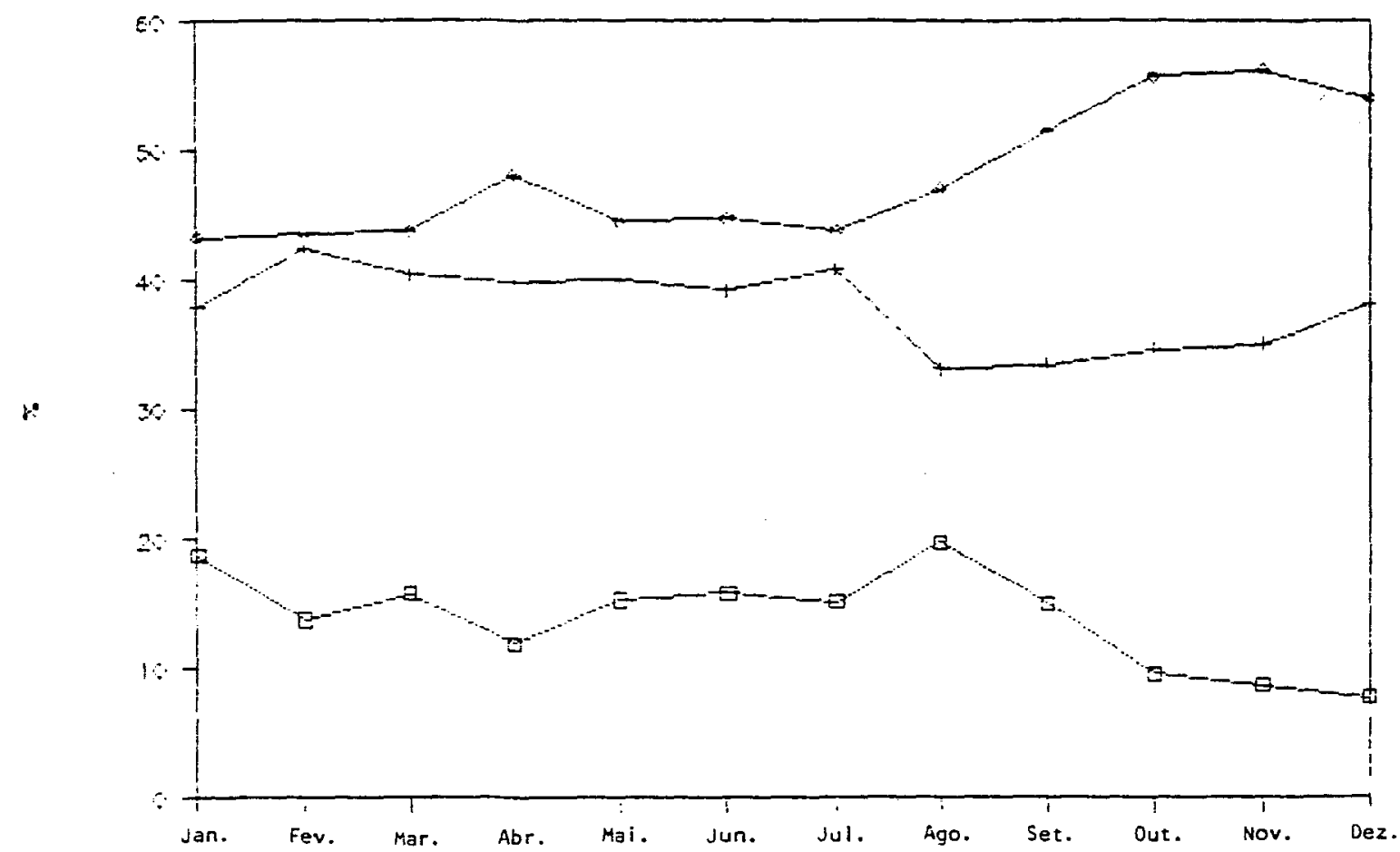

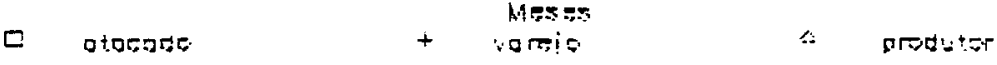

Figura 30.- Margens dorcentuais de ccmercializaça de carne bovina do atacauo e do varejo e parcela dorcerival do prosutor, 1972.

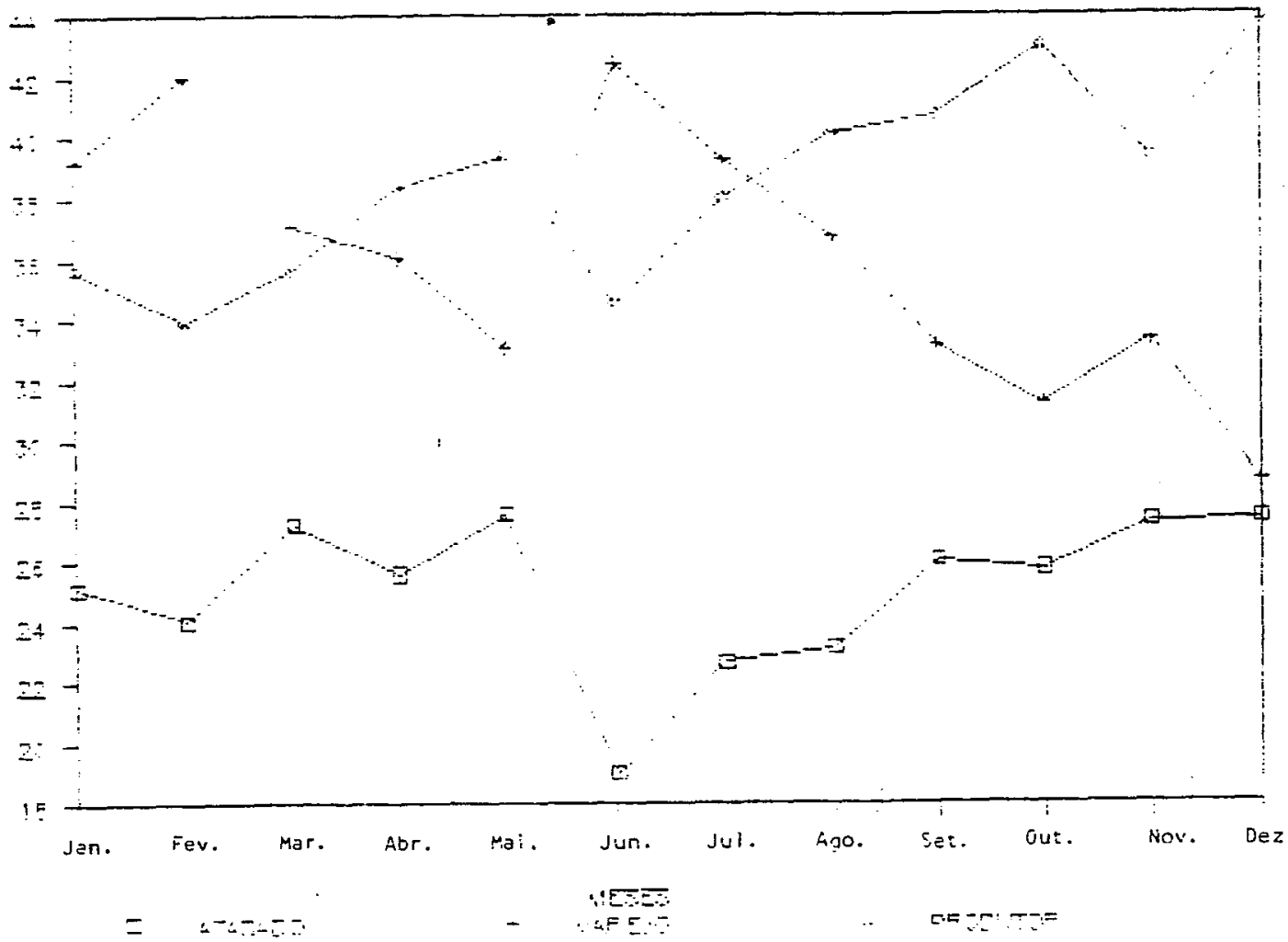

Figura 3i.. Maroens porcentuais oe comercializaçàc de carne bovina, 1983. 
labela 22.- Margens correntes de comen iali gaçä de carne bovina, jalleirn a dezembro de 1971

\begin{tabular}{|c|c|c|c|c|c|c|c|}
\hline \multirow[b]{2}{*}{ Mases } & \multicolumn{3}{|c|}{ Margens absolulas $(C<S / k g)$} & \multicolumn{4}{|c|}{ Margens porcentuais } \\
\hline & total & do atacady & do varejo & total & do atacado & do varejo & $\begin{array}{l}\text { Parcela do } \\
\text { producor }\end{array}$ \\
\hline Jallei ro & 77,96 & 38,17 & 39.79 & 53,14 & 26.02 & 27.12 & 46,86 \\
\hline Fevereiro & 76,76 & 36,54 & 40,22 & 52.66 & 25,07 & 27.59 & 47,34 \\
\hline Marso & 79.52 & 32,05 & 47.47 & 53,80 & 21,69 & 32,12 & 46,20 \\
\hline Atsil & 77.22 & 30,20 & 47,02 & 53,35 & 20,87 & 36,86 & 46,65 \\
\hline M.ric: & 76,80 & 24,63 & 52,17 & 53,20 & 17.07 & 36,14 & 46,80 \\
\hline Junhn & 14.40 & 23,78 & 50,62 & 52.53 & 16,79 & 35,74 & 47.47 \\
\hline Ju/ho & 75.62 & 23,32 & 52,30 & 53,12 & 16,38 & 36.74 & 46,88 \\
\hline Aljosto & 74.33 & 24,38 & 49,95 & 52,57 & 17.24 & 35,33 & 47,43 \\
\hline Sectembro & 83,20 & 25,74 & 57.46 & $55,2 y$ & 17.10 & 38,19 & 44,71 \\
\hline Outubra & 85,72 & 22,83 & 62,89 & 55,08 & 14.67 & 40.41 & 44.92 \\
\hline Noverubio & 90.31 & 21.11 & 69,20 & 55,90 & 13,06 & 42,83 & 44,10 \\
\hline De: $z$ t:mbian & 90.87 & 20,19 & 70.68 & 55.71 & 12.37 & 43.33 & 44.29 \\
\hline
\end{tabular}


Tobela 23. - Margens correntes de comercinlizą̧o de carne bovina, iareiro a dezembro de 1972

\begin{tabular}{|c|c|c|c|c|c|c|c|}
\hline \multirow[b]{2}{*}{ Meses } & \multicolumn{4}{|c|}{ Maryens absolutas $(C 25 / k !)$} & \multicolumn{3}{|c|}{ Margens porcentuais } \\
\hline & 10101 & du a tacato & do varejo & 10101 & do atacado & do varejo & $\begin{array}{l}\text { Parcela do } \\
\text { producor }\end{array}$ \\
\hline Jalle i i o & 91.47 & 30.34 & 61,13 & $56,0 y$ & 18,80 & 37,89 & 43,30 \\
\hline fevereidu & 89.83 & 22.06 & 67.77 & 56.28 & 13.82 & 42,46 & 43,72 \\
\hline M.15 & 89.01 & 25,04 & 63,97 & 56,22 & 15,82 & 40.40 & 43.78 \\
\hline Abril & 80.44 & 18,61 & 61.83 & 51.84 & 11,99 & 39,85 & 48,16 \\
\hline Mais & 85,73 & 23,74 & 61,99 & 55.48 & 15.36 & 40,12 & 44,52 \\
\hline surutwe & 83,36 & 24,08 & 29,28 & 55,27 & 15,96 & 39.31 & 44.72 \\
\hline JいI H, & 85,90 & 23,36 & 62,54 & 56.20 & 15,28 & 40,91 & 43,80 \\
\hline$\left.A_{(j)}=1,1\right)$ & 75,13 & 28,17 & 46,96 & 53,02 & 19.87 & 33,13 & 46,98 \\
\hline Sectembros & 68,79 & 21,38 & 47.41 & 48,58 & 15,10 & 33,48 & 51.42 \\
\hline Oulubio & 63,25 & 13,70 & 49,55 & 44,27 & 9.59 & 34,68 & 55,73 \\
\hline Novembro & 62.39 & 12,44 & 49,95 & 43.79 & 8,73 & $35 ; 06$ & 56,20 \\
\hline Desembirn & 68,27 & 11,60 & 56,67 & 45,96 & 7.81 & 38,15 & 54,03 \\
\hline
\end{tabular}


Tabela za. - Margens correntes de comercialicafio de carbe bovina, janeiro a dezembro de ig8z

\begin{tabular}{|c|c|c|c|c|c|c|c|}
\hline \multirow[b]{2}{*}{ Mesoes } & \multicolumn{4}{|c|}{ Marcuens ausulutas (Cas/hil) } & \multicolumn{3}{|c|}{ Margens porcentuais } \\
\hline & (c)tal & do atacado & do varejo & total & Ils atacioss & do varejo & $\begin{array}{l}\text { Parcela do } \\
\text { Lrodutor }\end{array}$ \\
\hline Janeiro & 100.88 & 39.44 & 61,44 & 64,35 & 25,16 & 39.19 & 35,66 \\
\hline Fevereill & 106,45 & 38,74 & 67.71 & 66,06 & 24,04 & 42,02 & 33.94 \\
\hline Murşo & 101,18 & 42,84 & 58,34 & 64.40 & 27,23 & 37,09 & 35.61 \\
\hline$A b, i l$ & 106.34 & 44,21 & 62.28 & 61.65 & 25,60 & 36,06 & 38,34 \\
\hline Maio & 100,00 & 45,47 & 54.52 & 60.61 & 27.60 & 33,04 & 39,40 \\
\hline Junhu & 96.14 & 29.69 & 66.45 & 61,45 & 18,98 & 42,47 & 38.55 \\
\hline Jullu & 117,05 & 42,87 & 74,18 & 62,00 & 22.71 & 39,29 & 38,00 \\
\hline$A(12,11)$ & 113,45 & 43.85 & 69,60 & 59,89 & 23,15 & 36.74 & 40,11 \\
\hline Setembru & 136,80 & 60,16 & 76.64 & 59,27 & 26,06 & 33,20 & 40,73 \\
\hline Oululiru & 121,60 & 54,98 & 66.62 & 57.00 & 25.77 & 31,22 & 43.01 \\
\hline$N_{1}, \mathrm{e}$ emlern & 125,31 & 56.46 & 68,85 & 60,6 & 27.34 & 33.33 & 39.33 \\
\hline Dextertson & 108.01 & 52.79 & 35.22 & 56,10 & 27.42 & 28,68 & 43,89 \\
\hline
\end{tabular}


Em 1972 e 1983 verifica-se que a parcela do produtor começa a crescer a partir do mês de julho (figuras 30 e 31) elevando-se até dezembro (meses de entressafra). Essas parcelas oscilaram entre $43,30 \%$ e $56,20 \%$ em 1972 e $33,94 \%$ e 43,89\% em 1983. Em 1971 o comportamento dessa parcela foi diferente (figura 29); ela começou a crescer em torno de março, atingiu valor mäximo em julho, permanecendo elevada até agosto e decrescendo de setembro a dezembro.

A amplitude de variação da parcela do produtor em 1971 foi bem menor que nos outros dois anos loscilou entre 44,10\% e 47,47\%), mostrando maior estabilidade ao longo do ano e um comportamento atípico dessa margem.

Observando as figuras 32 a 34 verifica-se que nos anos de 1972 e 1983 os comportamentos da margem porcentual total de comercialização säo semelhantes. os valores das margens são elevados de janei ro a março, sofrem uma queda em abril e maio e crescem até julho; de agosto a dezembro (entressafra) esses valores caem acentuadamente. Resultado semelhante foi obtido utilizando-se médias mensais de 1971 a 1987.

Em 1971 a margem porcentual total de comercializaçäo, ao conträrio dos outros dois anos, cresceu entre agosto e dezembro, sugerindo um comportamento atípico dos preços recebidos pelos mercados analisados no decorrer desse ano.

As margens absolutas totais de comercializa- 


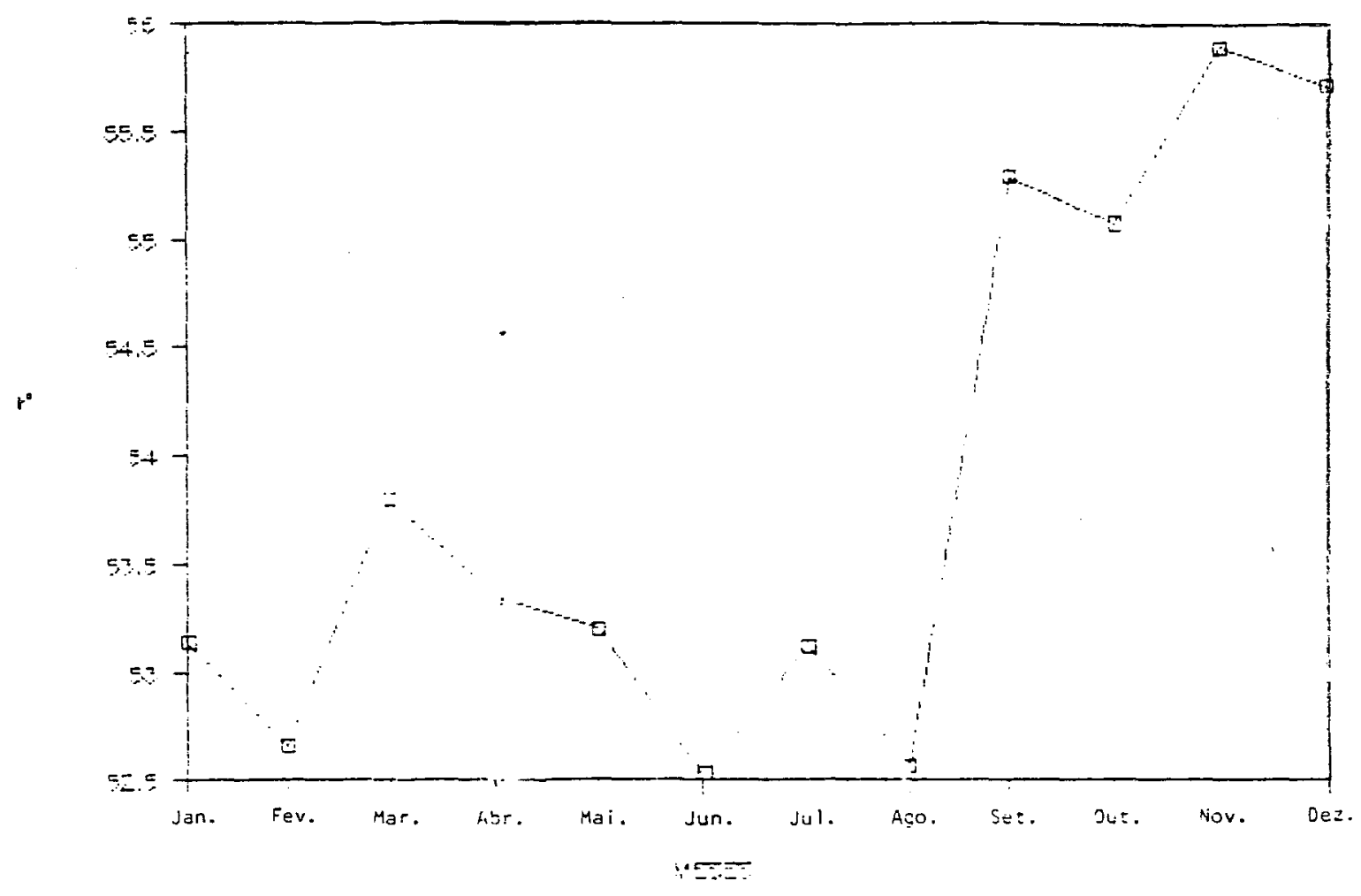

Figura 32. - Margem porcentuai total de comercializacào de carne dovina, 1971.

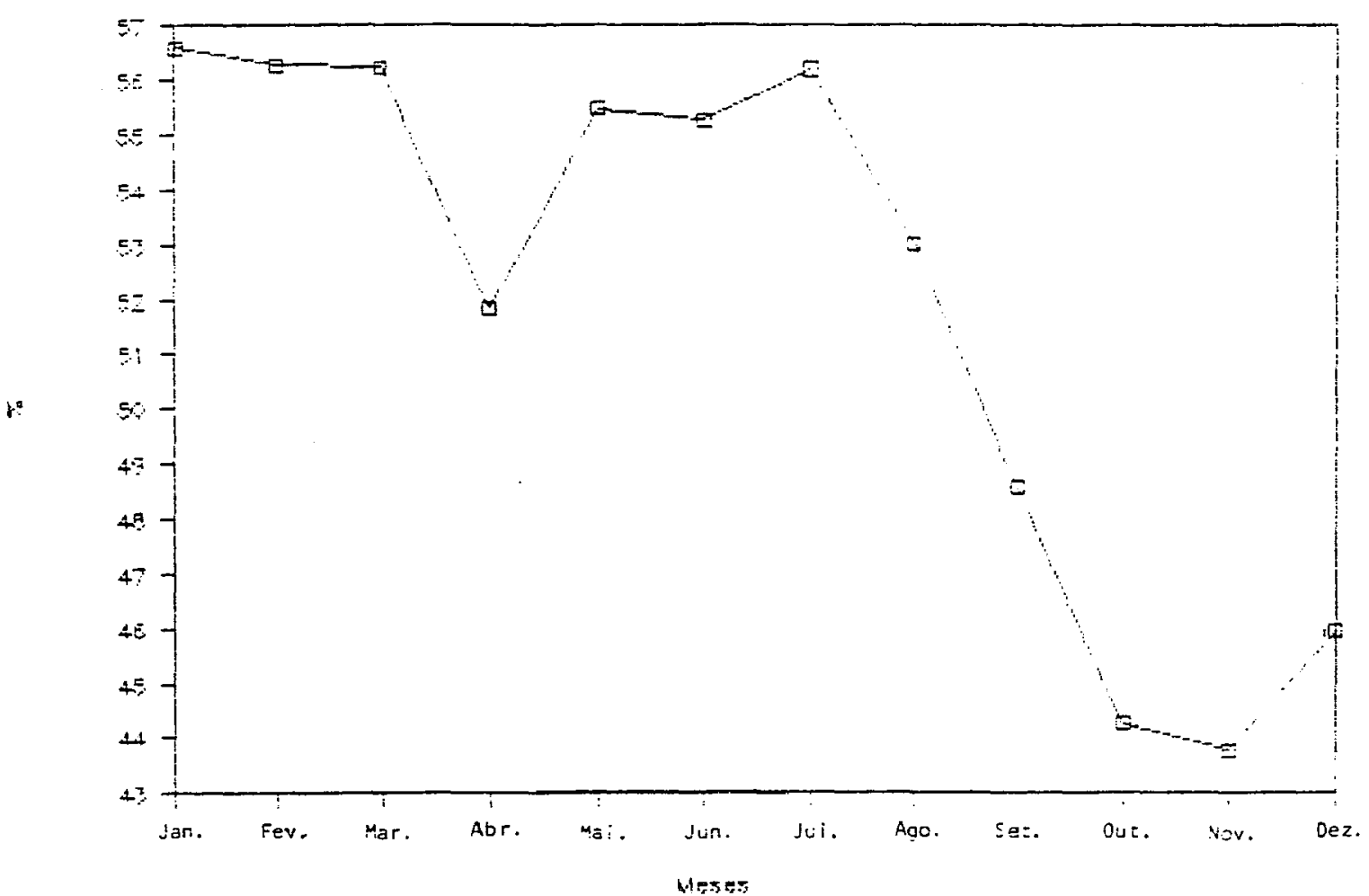

Figura 33. - Margem oorcentual total de comercializacäo je carrie bovina. 1972 . 


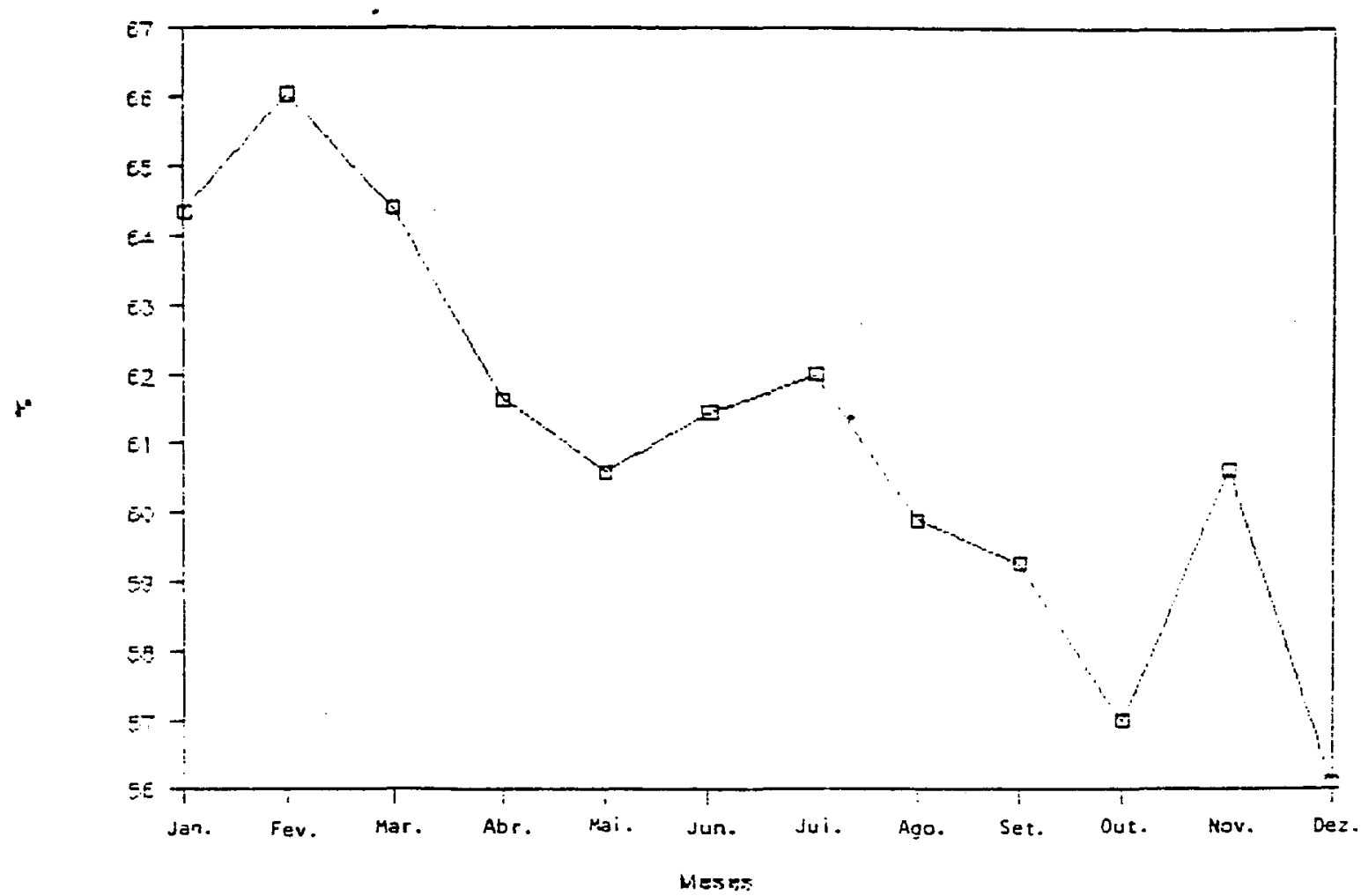

Figura 34. - Marger porcentual total de come-cializaçäo oe carne bovina. Ig83.

çāo de carne bovina estão representadas nas figuras 48,49 e 50, respectivamente (apèndice 3 ).

Nos anos de 1986 e 1987, anos de planos de es tabilização, as parcelas de comercialização do varejo foram as mais baixas, refletindo talvez aquelas políticas, enquanto as parcelas do atacado foram relativamente altas. Nesses anos, os dados podem não ter captado o ágio praticado pelos comerciantes em geral, provocando um viés. Consequentemen te, as parcelas de comercialização obtidas podem não refletir o verdadeiro comportamento do mercado de carne bovina. 
4. CONCLUSÕES

A natureza das relaçōes de transmissäo de preços da carne bovina entre os diferentes níveis de mercado foi analisada segundo o modelo de auto-regressão vetorial, de forma a identificar a origem das variações desses preços, estudar os mecanismos de propagação de choques sobre esses preços e determinar a intensidade e duração desses choques.

$$
\text { Alēm do modelo de auto-regressão vetorial, }
$$

utilizou-se na determinação do sentido de causalidade entre os preços o teste desenvolvido por GRANGER (1969) e SIMS (1972) e sugerido por BISHOP (1979), para exclusão de variäveis futuras com o intuito de comparar os resultados obtidos atravēs dos dois métodos e complementar a anälise.

Foram utilizados na análise de causalidade, preços recebidos pelos mercados atacadista e varejista da cidade de São Paulo; a nível de produtor utilizou-se preços recebidos pelos produtores dos Estados de São Paulo, Mato Grosso, Goiàs, Minas Gerais e Rio Grande do Sul.

De acordo com os resultados obtidos atravēs do modelo de auto-regressäo vetorial a anälise de causalidade revelou:

a) Efeito causal no sentido dos preços rece-. bidos pelo mercado varejista para o mercado atacadista, ao nível de $8 \%$ de significância; 
b) Efeito causal no sentido dos preços recebidos pelos produtores paulistas para os preços recebidos pelo mercado varejista ao nivel de $4 \%$ de significância;

c) Causalidade dos preços recebidos pelos produtores paulistas para o atacado e no sentido do varejo sobre os preços a nível de produtor paulista, a níveis de significãncia inferiores;

d) Auséncia de causalidade dos preços recebidos pelos produtores de Mato Grosso, Goiäs, Minas Gerais e Rio Grande do Sul sobre os mercados atacadista e varejista;

e) Efeito causal no sentido dos níveis de atacado e varejo para os mercados produtores de Minas Gerais, a 5\% de significāncia, e de Mato Grosso e Goiàs, a níveis de significância inferiores;

f) Ausência de influência significativa do atacado sobre o varejo e sobre o mercado produtor paulista;

g) Inexistência de variävel essencialmente exōgena, isto é, que não sofre influēncias de outras variàveis do sistema.

Uti lizando-se o método sugerido por BISHOP (1979), captou-se efeito causal no sentido do varejo para todos os mercados produtores analisados e do atacado para os produtores de Mato Grosso, Goiäs, Minas Gerais e Rio Grande do Sul. Apenas o mercado produtor de são paulo mostrou afe- 
tar de forma significativa os níveis de atacado e varejo da cidade de são paulo. Tais resultados são semelhantes aos obtidos pelo mëtodo de auto-regressäo vetorial.

Esses resultados revelam um papel relativamente passivo do atacado em relação aos demais níveis de mercado, em termos de variação de preços.

A anälise dos mecanismos de transmissão de choques entre os preços detectou existência de causalidade instantànea entre as variáveis.

Foi realizada análise dos efeitos de choques sobre os preços recebidos pelos produtores paulistas (PSP), atacadistas (A) e varejistas (V); utilizou-se a seguinte ordenação de variàveis. no sistema: PSP - V - A.

Com a ordenação P.SP-V-A verificou-se que, ing tantaneamente, um aumento de $10 \%$ nos preços recebidos pelos produtores paulistas provoca aumentos de $8,128 \%$ nos preços de varejo e de $7,07 \%$ nos preços de atacado; o preço ao produtor alcança aumento de $11,192 \%$ no més seguinte. No entanto, choques sobre o varejo afetam instantaneamente o atacado mas não o produtor e choques sobre o atacado não afetam os outros níveis de mercado.

Verificou-se que a intensidade dos efeitos de choques nos níveis de varejo e atacado decresce rapidamente, anulando-se todos os efeitos após os primeiros meses. Na análise da decomposição da variáncia dos 
erros de previsäo, de acordo com a ordenação PSP-V-A, verifi cou-se que a variància dos erros de previsāo é explicada, na sua maior parte, por inovaçōes em PSP; no caso de inovaçōes sobre $V$ e A, a maior parte da variáncia dos erros de previsão, em períodos longos, é explicada também por inovaçōes em PSP.

- resultado dessa anälise da decomposição da variáncia dos erros de previsão sugere que PSP seja uma variävel essencialmente exōgena, não afetada significativamente pelas demais. No entanto, ao alterar a ordenação das variäveis na anälise para A-V-PSP, os resultados se alteraram de maneira significativa; a importāncia das inovaçōes sobre PSP diminui, ao mesmo tempo em que aumenta a importância das inovações sobre A e V. Admite-se, então, que PSP não é variävel essencialmente exógena, resultado coerente com o obtido na anälise de causalidade.

Para anälise das sëries de preços de $1971 / 87$, foram calculadas margens correntes de comercialização, absolutas (em valores de dezembro de 1987) e porcentuais (como proporçāo do preço de varejo). Essas margens foram denominadas de parcelas, por não serem calculadas atravēs dos preços equivalentes na fazenda, devido a dificuldade. de obtenção dos preços dos subprodutos do boi a nível de atacado. Apesar dessas parcelas apresentarem valores diferentes das verdadeiras margens ambas deverão apresentar o mesmo comporta- 
mento ao longo do período analisado.

Em relação às parcelas de comercialização interanuais de carne bovina verificou-se que:

a) A parcela porcentual total de comercialização atingiu valor mäximo em $1982(50,04 \%)$ e valor mínimo em $1974(34,20 \%)$;

b) o valor máximo da parcela porcentual do varejo foi alcançado em $1973(46,65 \%)$ e o mínimo em 1986 $(24,14 \%)$

c) o valor mäximo da parcela porcentual do atacado foi atingido em $1982(14,63 \%)$.

d) Nos anos de 1973,1974 e 1978 as parcelas porcentuais do atacado $(-7,49 \%,-2,27 \%$ e $-0,17 \%$, respectivamente) sugerem que os agentes atacadistas trabalharam com margens muito pequenas ou até mesmo com prejuizo, embora não estejam computados os valores dos subprodutos em seu cálcu10 ;

e) As pequenas parcelas de comercialização obtidas nos anos de 1973,1974 e 1978 podem ser resultantes de politicas de intervenção governamental no mercado em apreço ou de problemas de ordem estatística;

f) A parcela porcentual do produtor atingiu valores mais elevados nos anos de 1974,1979 e $1986 \quad(65,81 \%$, $65,03 \%$ e $64,07 \%$, respectivamente) e valores mínimos em 1975 e $1982(55,15 \%$ e $49,96 \%$, respectivamente); 
g) A parcela porcentual do produtor ciresceu nas fases ascendentes do ciclo de preços reais do boi gordo $(1971 / 74,1977 / 79,1982 / 86)$ e decresceu nas fases descendentes desse ciclo $(1974 / 77,1979 / 82)$;

h) As parcelas porcentuais do produtor e do atacado apresentam comportamentos opostos. Nas fases ascendentes do ciclo de preços reais do boi gordo a parcela do produtor também cresce, porém a parcela do atacado decresce; nas fases nas fases descendentes do ciclo, em que a parcela do produtor decresce, a parcela do atacado cresce.

Analisando-se as parcelas porcentuais de comercialização de carne bovina obtidas pelos açougues e supermercados observou-se que:

a) Os supermercados trabalham com parcelas de comercializaçäo sempre inferiores àquelas obtidas pelos açougues;

b) Os comportamentos das parcelas de comercialização dos dois equipamentos varejistas são semelhantes, ao longo do período $1971 / 87$;

c) As parcelas de comercialização de carne bovina de segunda e de primeira têm comportamentos semelhan-. tes, tanto para os açougues como para os supermercados, em todo o período analisado;

d) A parcela porcentual de comercialização dos açougues é mäxima em $1978(46,86 \%)$ e a dos supermercados 
è mäxima em $1973(40,49 \%)$;

e) As parcelas porcentuais de comercialização da carne de segunda nos açougues e supermercados säo mäximas em $1978(47,60 \%)$ e $1973(37,97 \%)$, respectivamente;

f) As parcelas de comercialização da carne de primeira são mäximas para açougues e supermercados em 1973 $(50,66 \%$ e $45,03 \%$, respectivamente).

Quanto às parcelas de comercializaçāo intra- anuais de carne bovina observa-se que:

a) A parcela do produtor é mais elevada nos meses de entressafra (agosto-dezembro, aproximadamente), quando os preços reais do boi gordo recebidos pelos produtores são mais elevados;

b) A parcela do agente atacadista apresenta valores mais baixos nos meses da entressafra (principalmente de setembro a janeiro), com valor mínimo em novembro (3,09\%) e mäximo em março $(8,66 \%)$;

c) As parcelas dos supermercados são inferiores às parcelas dos açougues, tanto para carne de segunda como para carne de primeira;

d) Os valores mäximos das parcelas de comercializaçāo da carne de segunda pelos açougues e supermercados säo atingidos em fevereiro $(35,86 \%$ e $28,74 \%$, respectivamente); os valores mínimos são atingidos em setembro $(30,50 \%)$ e outubro $(19,33 \%)$, respectivamente; 
e) As parcelas de comercialização da carne de primeira dos açougues e supermercados são mäximas em dezembro $(41,52 \%)$ e junho $(36,51 \%)$, respectivamente; os valores mínimos ocorreram em setembro $(38,92 \%)$ e dezembro $(28,58 \%)$, respectivamente;

f) Ao longo do ano, as parcelas de comercialização dos açougues e supermercados tēm comportamento semelhante;

As margens de comercialização absolutas porcentuais, calculadas para os anos de 1971,1972 e não permitem conclusões generalizadas, para a sērie 1971/87, pois se referem a poucos anos e não apresentam comportamentos semelhantes ao longo ano em diversos aspectos.

Em 1972 e 1983 observou-se que a parcela do produtor cresceu nos meses de entressafra (julho a dezembro); em 1971 o comportamento dessa parcela foi diferente, crescendo de março a julho e decrescendo de setembro a dezembro. A amplitude de variação da parcela do produtor em 1971 foi bem menor que a observada nos outros dois anos.

Nos três anos analisados as margens de atacado e varejo apresentaram comportamentos opostos, ao longo dos meses, embora as magnitudes dessas margens tenham sido diferentes em cada ano.

Nos anos de 1972 e 1983 os comportamentos das margens porcentuais totais de comercialização mostraram-se 
semelhantes, caindo acentuadamente nos meses de entressafra (agosto a dezembro, principalmente). Em 1971 o comportamento da margem porcentual total de comercialização cresceu entre os meses de agosto e dezembro, mostrando comportamento at pico, pois, de acordo com os resultados anteriores, nos meses de entressafra a parcela do produtor tende a aumentar e a margem total de comercialização, a diminuir.

As parcelas de comercialização encontradas pạ ra os anos de 1986 e 1987 podem não refletir de maneira adequada o verdadei ro comportamento do mercado de carne bovina, pois estes foram anos de planos de estabilização (Planos Cruzado e Bresser), com congelamento de preços.Nesses anos,os da dos disponíveis podem não ter captado o àgio praticado pelos comerciantes, provocando um viēs.

Convēm salientar o importante resultado de que os efeitos de choques nos niveis de atacado e varejo anulam- se após os primeiros meses e os choques a nível de produtor, ao conträrio, persistem por períodos mais longos (cerca de trinta meses). Esses resultados indicam que os efeitos de po liticas que atuem de forma mais especifica sobre o nível de produção do boi gordo tendem a se refletir sobre o mercado em anālise por perfodo mais longo e com maior intensidade. 
REFERENCIAS BIBLIOGRAFICAS

ADABO, J.H. Tendência das margens de comercialização da car- ne bovina em São Paulo. Rio de Janeiro, 1978. (Especialização - EIAP/FGV).

ADABO, J.H. Anälise dos preços de atacado e varejo da carne bovina na cidade de São Paulo. São Paulo, 1980,145 p. (Mestrado - Escola de Sociologia e Politica de São Paulol USP) .

AGUIAR, D.R.D. \& BARROS, G.S.A.C. Transmissão de preços de laranja entre os mercados externo e interno. Revista de Economia e Sociologia Rural. Brasilia, 27(1):61-70, jan./ mar. 1989.

ASSOCIAÇAO BRASILEIRA DA INDULSTRIA DE ARMAZENAGEM FRIGORIFICA DA. Anälise da produção da carne bovina. São Paulo, 1980 , $15 \mathrm{p}$.

ASSOCIAÇÃO BRASILEIRA DA INDÚSTRIA DE ARMAZENAGEM FRIGORIFICA DA. Anālise da produção da carne bovina. São Paulo, 1982 , $22 \mathrm{p}$.

BARROS, G.S.C. Comercialização de produtos agrícolas e sua relação com a inflação brasileira. Piracicaba, ESALQ/USP, Instituto de Planejamento Económico e Social/USP e FEALQ, 1987, 174 p. (Relatörio de Pesquisa). 
BARROS, G.S.C. Economia da comercialização agricola. Piraci caba, FEALQ, 1987, $306 \mathrm{p}$.

BARROS, G.S.C. Transmissão de preços pela Central de Abastecimento de São Paulo, Brasil. Piracicaba, ESALQ/USP, $1988,20 \mathrm{p}$.

BARROS, G.S.A.C. \& BURNQUIST, H.L. Causalidade e transmissão de preços agricolas entre níveis de atacado e varejo. In: VII Encontro Latino Americano da Econometric Society, 1 , São Paulo, 1987. Anais P. 175-190.

BARROS, G.S.C. \& MARTINS FỌ, J.G. Transmissão de preços agrí colas entre niveis de mercado. In: XV ENCONTRO NACIONAL DE ECONOMIA. 2. Salvador, Anais ANPEC, 1987. p. 53-68.

BARROS, G.S.C. \& XAVIER, L.E. Aspectos da comercialização e seus efeitos sobre os preços e rendas agrícolas. Revista de Economia Rural, Brasilia, $17(3): 25-50,1979$.

BESSLER, D.A. Relative price and money: a vector autorregression on brazilian data. American Journal of Agricultural Economics. New York, 66 (1):25-30, 1984 .

BISHOP, R.V. The construction and use of causality tests. Agricultural Economics Research. 31(4):1-6, 1979 .

BOX, G.E.P. \& JENKINS, G.M. Time series analysis forecasting and control. Holden-Day Inc., San Francisco-Califörnia. 1976. 
BRANDAO, A.S. Moeda e preços relativos: evidencia empírica. Revista de Econometria, $\underline{V}(2): 33-80,1985$.

BRASIL, Ministērio da Agricultura. Mercado Átacadista de Gado e Carne; Análise da Variação dos Preços; Retrospecto de 1972. Rio de Janeiro, Conselho Nacional de Desenvolvimento da Pecuäria, 1973.

BRASIL, Winistērio da Agricultura. Mercado Nacional de Carne e Produtos Derivados, vol. 1 e 11 , maio/1973.

BRASIL, Ministerrio da Agricultura. Cotações Médias do Boi Gordo no Mercado Atacadista. Pesquisa Especial. Rio de Janeiro, 1973.

BURNqUIST, H.L. A questão da causalidade entre preços a dife rentes niveis de mercados agrícolas. Piracicaba, 1986 83 p. (Mestrado - ESALQ/USP).

CAMARGO, J.R.S. Comercialização de carne bovina por frigorificos abastecedores da zona metalürgica - 1967. Viçosa, 1968,84 p. (Mestrado - UREMG).

CANTO, W.L. Sistema ponderal de conversões e determinação de margens de comercialização. Campinas, Instituto de Tecnologia de Alimentos, 1986, $55 \mathrm{p}$.

CARMO, I.M. Anālise da comercialização da carne bovina no Es tado de São Paulo. Piracicaba, 1969, 87 p. (Mestrado-ESALQ/USP). 
CHAMBERS, R.G. Agricultural and financial market interdependence in the short run. American Journal of Agricultural Economics. New York, (1):12-24, 1984 .

D'APICE, M.L.B. \& JUNQUEIRA, P.C. Distribuição varejista de carnes na cidade de São Paulo: características, estrutura e custos (Parte 1). Agricultura em São Paulo. São Paulo, $19(2): 1-48,1972$.

D'APICE PAEZ, i.L.B. Parque industrial de carnes - caracteristicas e eficiência das unidades abatedoras de bovinos do Estado de São Paulo. IEA, Secretaria da Agricultura, Governo do Estado de São Paulo, 1978, $107 \mathrm{p}$.

DIAS, G.L.S. Alguns aspectos da pecuäria de corte da região Centro-sul. Estudos AMPES. São Paulo, n: 7, $1971,58 \mathrm{p}$. (Sērie monografias).

DIAS, G.L.S. Avaliação da política econômica para a pecuária de corte no Brasil. Säo Paulo, 1972. (Doutorado-FEA/USP).

DOAN, T.A. \& LITTERMAN, R. Rats user's manual. Minneapolis$-M n, 1981$.

FEIGE, E.L. \& PEARCE, D.K. The casual relationship between money and income: some caveats for time series analysis. Review of Economics and Statistics, 1979, p. 521-533.

FUNDAÇÃO GETULLIO VARGAS. Conjuntura Econōmica. Rio de Janei ro (diversos). 
FUNDAÇAO GETULIO VARGAS. Preços recebidos pelós agricultores. Rio de Janeiro, Centro de Estudos Agrícolás (diversos).

FUNDAÇAO INSTITUTO BRASILEIRO DE GEOGRAFIA E ESTATISTICA. EStudo Nacional de Despesa Familiar, Rio de Janeiro, 1978.

FUNDAÇAO INSTITUTO DE PESRUISAS ECONOMICAS. Pesquisa de orcamentos Familiares / USP, 1981/82.

GARCIA, E.A.C. Os preços da pecuāria bovina no Pantanal Mato grossence. Pesquisa Agropecuäria Brasileira. Brasilia, $\underline{19}(2): 123-148,1984$.

GARDNER, B.L. The farm - retail price spread in a competitive food industry. American Journal of Agricultural Economics, 57 (3):399-409, 1975 .

GRANGER, C.W.J. Investigating causal relations by econometric models and cross-spectral methods. Econometrica, $37(3)$ : $424-438,1969$.

HEIN, D.M. Markup princing in a dynamic model of the food industry. American Journal of Agricultural Economics, $\underline{62}(1): 10-18,1980$.

INSTITUTO DE ECONOMIA AGRICCOLA. Informações Econômicas. São Paulo, Secretaria da Agricultura do Estado de São Paulo. (diversos). 
148.

JUNRUEIRA, P.C.; LINS, E.R. de; AMARO, A.A. Comercialização de produtos agrícolas no Estado de São Paulo. Agricultura em São Paulo, 15 $(1 / 2): 13-32$, jan./fev. 1968.

JUNRUETRA, P.C. \& CANTO, W.L. Cesta de mercado: margens totais de comercialização. Agricultura em São Paulo, $18(9 /$ (10):1-46, set./out. 1971 .

KASSOUF, A.L. Previsão de preços na pecuária de corte do Estado de São Paulo. Piracicaba, 1988, 102 p. (Mestrado - ESALQ/USP).

KMENTA, J. Elementos de Econometria. São Paulo, Atlas, 1978, $670 \mathrm{p}$.

MARqUES, M.S.B. Moeda e inflação: a questão da causalidade. Revista Brasileira de Economia, Rio de Janeiro, $37(1): 13-$ -38, jan./mar. 1983.

MASCOLO, J.L. Um estudo economëtrico da pecuäria de corte no Brasil. Revista Brasileira de Economia. Rio de Janeiro, 33 (1):65-105, jan./mar. 1979 .

MARTINES Fọ, J.G. Margens de comercialização e causalidade de preços agrícolas. Piracicaba, 1988, 146 p. (Mestrado - ESALQ/USP).

MORETTIN, P.A. \& TOLOI, C.M.C. Modelos para previsão de séries temporais. In: 13 : Colóquio Brasileiro de Matemätica. Poços de Caldas, CNPq/IMPA, vol. 1, 1981. 
MUELLER, C.C. O ciclo do gado e as tentativas de controle do preço da carne. Estudos Económicos, São Paulo, $17(3)$ : $435-456,1987$.

NASCIMENTO, A.F.M. Custos e beneficios sociais da política de estoques reguladores de carne bovina no Brasil. Viçosa-MG, 1981 (Mestrado - UFV).

PECEGUINI, E.E. Redimensionamento da amostra para levantamento de precos a nivel de varejo na cidade de são Paulo. São Paulo, IEA, Secretaria da Agricultura, 1979, 49 p. (Relatoó rio de Pesquisa).

PIERCE, D.A. \& HAUGH, L.D. Causality in temporal systems. Journal of Econometrics. 5 (1977), p. 265-293.

PINo, F.A. Anālise de intervenção em sēries temporais - apli caçōes em economia agrícola. São Paulo, 1980, 253 p. (Me s trado - IME/USP).

PINO, F.A.; NOGUEIRA IR., S. \& TOLOI, M.C. Dynamic relations in brazilian soybean prices. Pesquisa Agropecuária Brasileira. Brasília, 18(11):1163-1173, nov./1983.

SANTIAGO, M.M.D. (coord.). Estatistica agricola de preços do Estado de São P.aulo. São Paulo, Secretaria da Agricultura, Instituto de Economia Agrícola, 2 vols., cap. 5, 1988, p. $22-35$. 
SĂO PAULO. Serviço de Defesa Sanitäria Animal, Boletim Interno(1984).

SAO PAULO. Caracterização da bovinocultura de corte no Estado de São Paulo. Campinas, Secretaria da Agricultura e Abastecimento, Coordenadoria de Assistência Técnica Integral, n? 58, fevereiro/1985.

SAO PALLO. Secretaria da Agricultura. Instituto de Economia Agrícola. Agricultura: Situação e Perspectiva. São Paulo, v. 2,1986 .

SARGENT, T.J. Macroeconomic theory. New York, Academic Press, 1979.

SIMS, $C$. Money, income and causality. American Economic Review. $62(4): 540-552,1972$.

SIMS, C. Macroeconomics and reality. Econometria, 48(1):1-48, 1980.

SOUZA, C.S. Produção e comercialização de gado e carne. (A) guns aspectos). Rio de Janeiro, CEPEN (SUPLAN - Ministério da Agricultura), $1974,122 \mathrm{p}$.

STOKES, H.H.; NEUBURGER, H. The effect of monetary changes on interest rates: a Box-Jenkis approach. Review of Ecomics and Statistics, nov./1979, p. 534-548.

SUEYOSHI, M.L. et alii: Cesta de mercado: atualização da estrutura de consumo e fatores de ponderação de preços. Informaçōes Econōmicas. São Paulo, 15(10):19-35, out./1985. 
TEIXEIRA, H.H.L. Modelo de desequilíbrio de margens de comer cialização agrícola. Viçosa, 1982, 62 p. (Mestrado-UfV).

TIAO, G.C. \& BOX, G.E.P. Modeling multiple time series with aplications. Journal of the American Statistical Association, vol. $\underline{76}(376): 802-816$, dec./1981.

UENO, L.H. Cesta de mercado: redimensionamento da amostra de equipamentos comerciais. Informações Econōmicas, são Pau $10, \underline{6}(2): i-q$, fev. $/ 1976$.

VIEIRA, L.F. \& RENESTO, O.V. O mercado varejista de carne bovina e a perspectiva de inovação tecnológica. Campinas, Estudos Económicos - Alimentos Processados, ITAL - Coordenadoria da Pesquisa Agropecuäria, Secretaria de Agricultura, Governo do Estado de São Paulo, 1977, 33 p. 
APENDICE I 
Tabela 25. - Presos correntes do quarto didnlibo, recebidos pelo mercado atacadista de carne buvina da cidade de jas paulo, no períado $1971 / 87$, enc $\operatorname{cr} \$ / \mathrm{kg}$

\begin{tabular}{|c|c|c|c|c|c|c|c|c|c|c|c|c|}
\hline \multirow{2}{*}{ Ario } & \multicolumn{12}{|c|}{ MESES } \\
\hline & Jan. & Fev. & Mar. & Abl: & Mai. & Jun. & Jul. & Ago. & Set. & Out. & Nov. & Dez. \\
\hline 1911 & 2,64 & 2,61 & 2,58 & 2,55 & 2,47 & 2,45 & 2.45 & 2,52 & 2,62 & 2.65 & 2,67 & 2,70 \\
\hline $19 / 2$ & 3.04 & 2,80 & 2.95 & 2,95 & 2,95 & 2,95 & 2,95 & 3.18 & 3,20 & 3,20 & 3,20 & 3.20 \\
\hline 1973 & 3.35 & 3,50 & 3,50 & 3,50 & 3.50 & 3.50 & 3,50 & 3,50 & 3.50 & 3,50 & 3,50 & 3.50 \\
\hline 1974 & 3,50 & 3,50 & 5,00 & 5,10 & 5.10 & 5,20 & 5,20 & 5,20 & 5,20 & 5,20 & 5,20 & 5.20 \\
\hline 1975 & 6,30 & 5.75 & 5,84 & 6,10 & 6,12 & 6,15 & 6.15 & 6,30 & 6,50 & 6,50 & 6,85 & 8,36 \\
\hline 1976 & 8,50 & 8,50 & 8,50 & 8,50 & 7,87 & 7.53 & 7,87 & 8,20 & 8,20 & 7,93 & 7.90 & 7.90 \\
\hline 1977 & 9,04 & 9.54 & 9.50 & 9,73 & 10,10 & 10,10 & 10,10 & 10,10 & 10,10 & 10,10 & 10,10 & 10,10 \\
\hline 1978 & 10,10 & 12,34 & 13,90 & 13,90 & 15.10 & 16,35 & 16,00 & 16.00 & 21,24 & 24,73 & 24,03 & 25,34 \\
\hline 1979 & 26,71 & 27.84 & 28,40 & 28,96 & 29,61 & 30,25 & 39,50 & 56,20 & 62,50 & 66,25 & 70,00 & 60,67 \\
\hline 1980 & 58,52 & 61,17 & 60,21 & 39,08 & 62,31 & 64,40 & 74,95 & 90,00 & 93,95 & 108.76 & 105,68 & 105,20 \\
\hline 1981 & 107,31 & 109,02 & 108,81 & 111.45 & 106,25 & 102,50 & 107,82 & 126,90 & 157.49 & 166,75 & 164,65 & 169,31 \\
\hline 1982 & 168,41 & 167.50 & 160,97 & 158,67 & 167,95 & 192,85 & 255,50 & 265,45 & 277,60 & 288,82 & 292,10 & 287.50 \\
\hline 1983. & 280,00 & 282,94 & 330.68 & 416,00 & 458,54 & 446,19 & 667,50 & 759.56 & 1.040 .23 & $1.160,78$ & $1.132,50$ & $1.250,00$ \\
\hline 1984 & $1.171,42$ & $1.278,57$ & 1.313 .15 & $1.353,94$ & $1.735,71$ & $1.859,52$ & $2.114,28$ & $2.404,78$ & 3.123 .68 & $3.418,18$ & $3.365,00$ & 3.073 .61 \\
\hline 1985 & $3.021,00$ & $3.052,00$ & 3.154 .00 & $3.118,00$ & $3.185,00$ & $3.286,00$ & $5.738,00$ & $7.936,00$ & $8.821,00$ & $9.409,00$ & $11.610,00$ & $12.163,00$ \\
\hline 1986 & $12.756,00$ & $14.000,00$ & $\left.14,200^{1}\right)$ & 14,15 & 13.33 & 17.77 & 22,20 & 18,78 & 20,50 & 20.52 & 21,13 & 29,64 \\
\hline 1987 & 29,13 & 26,90 & 30,00 & 32,24 & 39.50 & 41,00 & 43,00 & 48,25 & 53,96 & 59.89 & 68,63 & 66,68 \\
\hline
\end{tabular}

Funte: Instituto de Economia Agrícula - IEA.

(') a partir de março de 1986 presus elll C $2 \$ / k g$. 
MUELLER, C.C. O ciclo do gado e as tentativas de controle do preço da carne. Estudos Económicos, São Paulo, $17(3)$ : $435-456,1987$.

NASCIMENTO, A.F.M. Custos e beneficios sociais da política de estoques reguladores de carne bovina no Brasil. Viçosa-MG, 1981 (Mestrado - UFV).

PECEGUINI, E.E. Redimensionamento da amostra para levantamento de precos a nivel de varejo na cidade de são Paulo. São Paulo, IEA, Secretaria da Agricultura, 1979, 49 p. (Relatoó rio de Pesquisa).

PIERCE, D.A. \& HAUGH, L.D. Causality in temporal systems. Journal of Econometrics. 5 (1977), p. 265-293.

PINo, F.A. Anālise de intervenção em sēries temporais - apli caçōes em economia agrícola. São Paulo, 1980, 253 p. (Me s trado - IME/USP).

PINO, F.A.; NOGUEIRA IR., S. \& TOLOI, M.C. Dynamic relations in brazilian soybean prices. Pesquisa Agropecuária Brasileira. Brasília, 18(11):1163-1173, nov./1983.

SANTIAGO, M.M.D. (coord.). Estatistica agricola de preços do Estado de São P.aulo. São Paulo, Secretaria da Agricultura, Instituto de Economia Agrícola, 2 vols., cap. 5, 1988, p. $22-35$. 


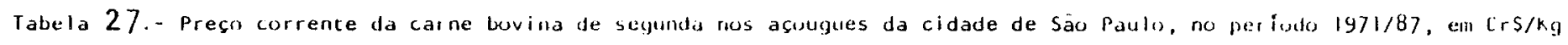

\begin{tabular}{|c|c|c|c|c|c|c|c|c|c|c|c|c|}
\hline \multirow{2}{*}{ Ano } & \multicolumn{12}{|c|}{ MESES } \\
\hline & Jan. & Fev. & Mar. & $A b r$. & Mai. & Jun. & Jul. & Ago. & Set. & out. & Nov. & Dez. \\
\hline 1971 & 3.60 & 3,65 & 3.79 & 3,69 & 3,80 & 3.78 & 3,91 & 3,81 & 4,18 & 4,49 & 4.78 & 4.84 \\
\hline 1972 & 4,84 & 4,93 & 4,84 & 4,84 & 4,88 & 4,78 & 4,96 & 4,40 & 4.45 & 4,59 & 4,66 & 4,91 \\
\hline 1973 & 5,52 & 5,23 & 5,08 & 5.31 & 5.80 & 5.79 & 6,15 & 1.59 & 9.59 & 10,60 & 10,84 & 8.13 \\
\hline 1974 & 5,42 & 5.79 & 6,20 & 8,40 & 7,76 & 7,78 & 8,24 & 1,68 & 7.99 & 7.60 & 7,53 & 7.80 \\
\hline 1975 & 8,30 & 9,59 & 10,21 & 9.95 & 10,26 & 10,80 & 11,34 & 10,89 & 8,37 & 8.16 & 11,16 & 13,10 \\
\hline 1976 & 13,05 & 13,28 & 13.47 & 11.90 & 11,85 & 11,55 & 11.75 & 12,84 & 11.92 & 12,04 & 12.39 & 11.84 \\
\hline 1977 & 15.03 & 15.64 & 15.29 & 15,19 & 15.66 & 15,49 & 17,21 & 17.41 & 17.09 & 17.76 & 20,44 & 22.06 \\
\hline 1978 & 24.15 & 23,90 & 25.96 & 25.45 & 26,32 & 28,51 & 33.17 & 35,50 & 39.84 & 46,37 & 44,14 & 43.69 \\
\hline 1979 & 44,64 & 44,73 & 44.73 & 49.39 & 49,63 & 50,61 & 58,05 & 72,89 & 74.34 & 83.38 & 92,14 & 86.74 \\
\hline 1980 & 90,83 & 85,98 & 85.99 & 90,61 & 96,60 & 96,68 & 117,03 & 123,46 & 133,00 & 148,82 & 143,14 & 144,79 \\
\hline 1981 & 159,50 & 148,94 & 154,70 & 137,76 & 159,12 & 156.74 & 176,77 & 190,93 & 209,85 & 232,43 & 234,32 & 241,17 \\
\hline 1982 & 256,76 & 263.62 & 253.98 & 271,54 & 261,48 & 306.57 & 391,43 & 409.39 & 428,84 & 435,41 & 413,99 & $448,30^{\circ}$ \\
\hline 1983 & 416,23 & 494,97 & 525,27 & $6,1,14$ & 671,48 & 717.15 & $1.006,74$ & $1.152,00$ & $1.568,00$ & $1.661,00$ & 1.739 .00 & $1.634,00$ \\
\hline 1984 & $1.768,00$ & $1.902,00$ & $1.936,00$ & 1.910 .00 & $2.508,00$ & $2.650,00$ & $2.906,00$ & $3.260,00$ & $4.471,00$ & $4.687,00$ & $4.680,00$ & $4.550,00$ \\
\hline 1985 & $4.725,00$ & $4.513,00$ & 4.774 .00 & $4.751,00$ & $4.659,00$ & $4.634,00$ & 7.979 .00 & $10.569,00$ & $11.471,00$ & 12.895 .00 & $16.520,00$ & $16.774,00$ \\
\hline 1986 & $18.247,00$ & $19.572,00$ & $\left.19,381^{\prime}\right)$ & 19,04 & 18,74 & $19.330,00$ & 19,50 & 19,58 & 21,53 & 25,44 & 27,40 & 42,33 \\
\hline 1987 & 46,62 & 41.73 & 41,71 & 44.75 & 55.44 & 56,94 & 57.75 & 59.37 & 64,46 & 74,34 & 90,47 & 93,43 \\
\hline
\end{tabular}

Fonte: Instituto de Economia Agrícola - IEA.

(') a partir de março de 1986 preços en $C 2 \$ / \mathrm{kg}$. 


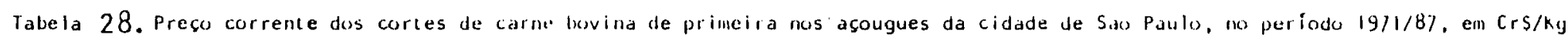

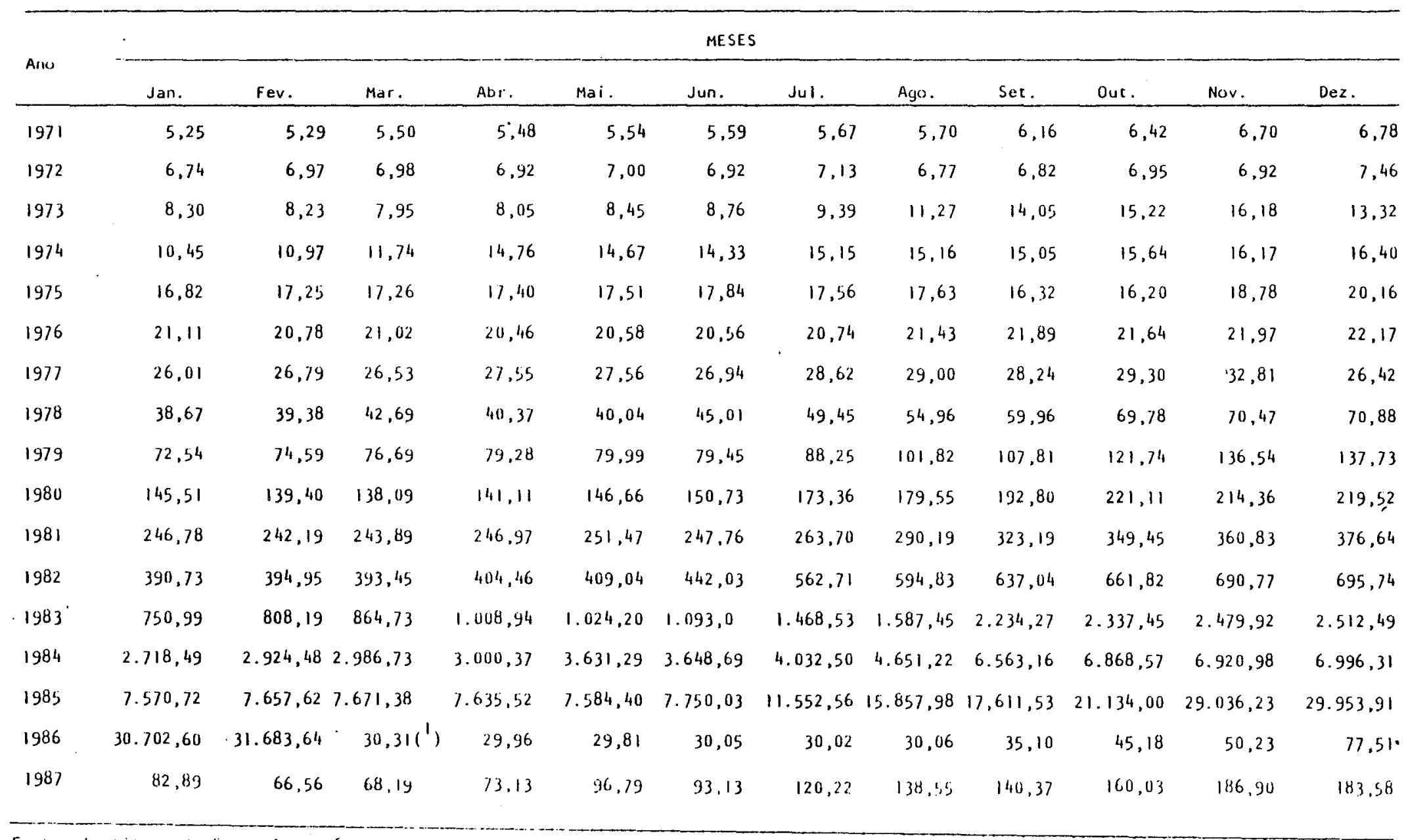

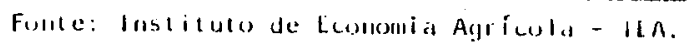

(') a partir de marşo de 1986 presos tem $c 2 \$ / k$, s. 


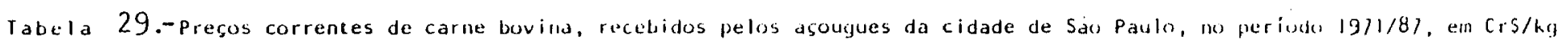

\begin{tabular}{|c|c|c|c|c|c|c|c|c|c|c|c|c|}
\hline \multirow{2}{*}{ Ano } & \multicolumn{12}{|c|}{ MESES } \\
\hline & Jan. & Fev. & Mar. & Abir. & Mai. & Jun. & Jul. & Ago. & Set. & our. & Nov. & Dez. \\
\hline 1971 & 4.51 & 4.55 & 4,73 & 4.66 & 4.76 & 4.78 & 4,88 & 4,88 & 5,27 & 5.55 & 5,83 & 5.91 \\
\hline 1972 & 5.89 & 6.05 & 6,02 & 5,99 & 6,05 & 5,96 & 6,16 & 5,71 & 5,76 & 5.89 & 5.91 & 6,31 \\
\hline 1973 & 7,05 & 6,88 & 6.66 & 6,85 & 7.26 & 7,42 & 7,94 & 9,62 & 12,07 & 13.15 & 13,78 & 10.98 \\
\hline 1974 & 8,18 & 8,64 & 9,25 & 11.90 & 11.57 & 11,39 & 12,05 & 11.81 & 12,13 & 12,03 & 12,29 & 12,54 \\
\hline 1975 & 13,00 & 13,81 & 14,10 & 14,05 & 14,25 & 14,51 & 14,77 & 14,60 & 12,75 & 12.59 & 15,36 & 16.99 \\
\hline 1976 & 17,49 & 17,42 & 17,63 & 16,62 & 16,66 & 16,52 & 16,70 & 17.57 & 17,41 & 17.33 & 17.67 & 17,54 \\
\hline 1977 & 21,08 & 21,79 & 21,49 & 22,18 & 22,22 & 21,80 & 23,50 & 23,80 & 23,24 & 24,12 & 27,26 & 29,98 \\
\hline 1976 & 32,16 & 32,43 & 35,18 & 33,68 & 33,88 & 37,60 & 42,14 & 46,27 & 50,93 & 59,28 & 58,66 & 58.68 \\
\hline 1979 & 60,02 & 61.19 & 62.35 & 65,87 & 66,37 & 66.50 & 74,70 & 88,84 & 92,79 & 104,53 & 116,61 & 114.85 \\
\hline 1980 & 120,97 & 115.43 & 114,71 & 118,45 & $\cdot 124,20$ & 126.48 & 148,08 & 154,38 & 165,97 & 188,67 & 182,40 & 185.99 \\
\hline 1981 & 207.61 & 200.35 & 203.86 & 206.94 & 210,03 & 206,92 & 225,97 & 245,65 & 272,33 & 296.94 & 304,06 & 315,85 \\
\hline 1982 & 330,61 & 336,02 & 330,90 & $34,4,80$ & 342.85 & 381,25 & 485.85 & 511,62 & 543,62 & 560,25 & 566.57 & 584.71 \\
\hline 1983 & 600,78 & 667,64 & 712,41 & $84,3,40$ & 865,93 & 924,41 & 1.261 .31 & $1.392,06$ & 1.935 .31 & $2.034,00$ & 2.147 .00 & $2.118,00$ \\
\hline 1984 & 2.292 .00 & $2.466,00$ & $2.515,00$ & $2.511,00$ & $3.127,00$ & $3.201,00$ & $3.527,00$ & $4.027,00$ & $5.624,00$ & $5.890,00$ & $5.915,00$ & $5.899,00$ \\
\hline $1985^{\circ}$ & $6.294,00$ & $6.247,00$ & $6.371,00$ & 6.341 .00 & $6.272,00$ & $6.352,00$ & $9.949,00$ & $13.485,00$ & $14.856,00$ & $17.437,00$ & $23.420,00$ & $24.040,00$ \\
\hline 1986 & $25.114,00$ & 26.285 .00 & $25.41\left(^{1}\right)$ & 25,00 & 24,84 & 25,24 & 25,30 & 25,17 & 28,82 & 32,58 & 39.99 & 61,73 \\
\hline $198 \%$ & 66,61 & 55,42 & 56,31 & 60,40 & 78.23 & 76.89 & 92,19 & 103,02 & 106,31 & $|z|, 58$ & 143.63 & 143,13 \\
\hline
\end{tabular}

Fonte: Instituto de Economia Agrícola -IEA.

(') a partir de marco de 1986, preçus en Cz\$/ky. 


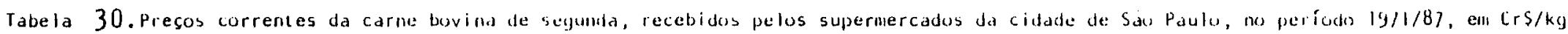

\begin{tabular}{|c|c|c|c|c|c|c|c|c|c|c|c|c|}
\hline \multirow{2}{*}{ Ano } & \multicolumn{11}{|c|}{ MESES } & \multirow[b]{2}{*}{ Dez. } \\
\hline & Jan. & Fev. & Mar. & Abr. & Mai. & Jun. & Jul. & Acyo. & Set. & Out & Nov. & \\
\hline 1971 & 3,51 & 3,59 & 3,67 & 3,69 & 3,74 & 3,74 & 3,82 & 3.89 & 4,21 & 4,29 & 4,48 & 4,62 \\
\hline 1972 & 5,15 & 4,50 & 4,95 & $4 ; 63$ & 4.71 & 4,55 & 4.59 & 4,42 & 4.48 & 4,55 & 4,56 & 4,57 \\
\hline 1973 & 5,70 & 4,99 & 5.09 & 3,26 & 4,81 & 4,99 & 5,27 & 6.27 & 7.23 & 7,00 & 6.59 & 5,55 \\
\hline 1974 & 4,50 & 4,86 & 4,79 & 7,43 & 7,31 & 7,30 & 7.31 & 7.50 & 7.45 & 7.14 & 7.22 & 7,31 \\
\hline 1973 & 7,58 & 8,32 & 8,27 & 8,22 & 8,22 & 8.53 & 8,84 & 9,27 & 8,05 & 7,68 & 9,43 & 12,68 \\
\hline 1976 & 12,47 & 13,08 & 12,55 & 11,75 & 11.27 & 10,87 & 10,52 & 10,67 & 11.32 & 10,77 & 10,82 & 10,67 \\
\hline 1977 & 12,31 & 12.56 & 13,34 & 13,32 & 13,10 & 10,39 & 13.04 & 13.25 & 13,14 & 14.04 & 14.19 & 14,52 \\
\hline 1978 & 17.88 & 18,61 & 19,26 & 19.11 & 19,52 & 22,22 & 24.05 & 22,73 & 23,50 & 26,90 & 28,03 & 30.38 \\
\hline 1979 & 33,34 & 33,44 & 34,41 & 32,67 & 32.87 & 33.70 & 44,04 & 47,20 & 56,79 & 57.15 & 62,20 & $68: 30$ \\
\hline 1980 & 80,23 & 80,69 & 81,91 & 83,63 & 85,70 & 91,39 & 109.15 & 109.71 & 106,98 & 109,99 & 110.74 & 111.38 \\
\hline 1981 & 123,26 & 140,33 & 143,39 & 144,42 & 141,69 & 144,22 & 156,03 & 181.75 & 194,19 & 188,69 & 189,64 & 194.25 \\
\hline 1982 & 195,05 & 214,92 & 231,22 & 247,22 & 259,34 & 286,67 & 370,59 & 382,87 & 396,39 & 415.47 & 418,39 & 402,44 \\
\hline 1983 & 406,42 & 437,86 & 485,92 & 619.11 & 638,27 & 693,34 & 1.007 .42 & $1.101,00$ & 1.405 .12 & $1.520,00$ & $1.535,00$ & $1.544,00$ \\
\hline $1984^{\circ}$ & $1.711,00$ & $1.878,00$ & $1.933,00$ & $1.911,00$ & $2.510,00$ & $2.616,00$ & $2.815,00$ & 3.259 .00 & $4.388,00$ & $4.665,00$ & 4.678 .00 & $4.522,00$ \\
\hline 1985 & $1.471,00$ & $4.484,00$ & $4.476,100$ & 4.490 .00 & $4.378,00$ & $4.496,00$ & $7.832,00$ & 10.664 .00 & $11.185,00$ & $12.564,00$ & $15.499,00$ & $16.592,00$ \\
\hline 1986 & $17.738,00$ & 18.887 .00 & $\left.19,290^{\prime}\right)$ & 19.00 & 19,25 & 19.30 & 19,37 & 19.35 & 19,35 & 19,36 & 19,32 & 31,42 \\
\hline 1987 & 39,83 &.$\quad 39.36$ & 40,00 & 42,20 & 54,00 & 56.22 & 58,47 & 59.09 & 61,84 & 65.75 & 71,79 & 89.55 \\
\hline
\end{tabular}

Fonte: lustituto de foconomia Agrícula - ILA.

(') a partir de marso de 1986 presus en $C<\$ / k g$. 
Tabela 31.-Preços correntes da carne bovina de pimeira recebidos pelos supermercados da cidade de Sau Paulo, no período 1971/87, em Cr\$/kg

\begin{tabular}{|c|c|c|c|c|c|c|c|c|c|c|c|c|}
\hline \multirow{2}{*}{ Arro } & \multicolumn{10}{|c|}{ MESES } & \multirow[b]{2}{*}{ Nove. } & \multirow[b]{2}{*}{ Dez. } \\
\hline & Jan. & Fev. & Mar. & Abr. & Mai. & JuII. & Jul. & Ajo. & Set. & Out. & & \\
\hline 1971 & 5,21 & 5,22 & 5,37 & 5.43 & 4,58 & 5,49 & 5,58 & 5,62 & 6.05 & 6,24 & 6.51 & 6,70 \\
\hline 1972 & 6,64 & 6,64 & 6,80 & 6,81 & 6,59 & 6,64 & 6,67 & 6,67 & 6,78 & 6,78 & 6,92 & 6,84 \\
\hline 1973 & 8,23 & 7,63 & 7,79 & 7.76 & 7,61 & 7,62 & 8,20 & 9.89 & 11,08 & 14.96 & 11,96 & 10,78 \\
\hline 1974 & 9.59 & 9.86 & 9,89 & 14.00 & 13,95 & 14.10 & 14.68 & 14.79 & 15,06 & 15.18 & 15,41 & 15,39 \\
\hline 1975 & 16,25 & 16,06 & 16,25 & 16.112 & 15,95 & 16,23 & 16,50 & 16,58 & 15,81 & 15,69 & 17,23 & 18,94 \\
\hline 1976 & 19,61 & 19,81 & 19.77 & 19.53 & 19,48 & 19,66 & 19.23 & 19,31 & 19,50 & 19,34 & 19,32 & 19,45 \\
\hline 1977 & 22.93 & 23,46 & 24,09 & 24,13 & 23,96 & 24,16 & 24,07 & 24,17 & 24,11 & 24,81 & 24,86 & 25.72 \\
\hline 1978 & 33.62 & 34,06 & 34,89 & 35,02 & 34.11 & 38,34 & 42,32 & 41,29 & 41,64 & 46,43 & 48,20 & 53.10 \\
\hline 1979 & 61,29 & 62,46 & 62,84 & 61,18 & 61,86 & 62,27 & 78,13 & 81,23 & 92,42 & 93,19 & 100,41 & 109,31 \\
\hline 1980 & 128,43 & 130,83 & 128,36 & 129,09 & 130.96 & 143,26 & 166,61 & 166,87 & 165,38 & 171,23 & 172,84 & 168,94 \\
\hline 1981 & 192,38 & 227.71 & 233.77 & 231,16 & 234.73 & 232,00 & 249,92 & 281.50 & 292,02 & 286,18 & 289,57 & 297.98 \\
\hline 1982 & 309.91 & 324.07 & 337.47 & 355,90 & 276,23 & 401,13 & 518,16 & 558,64 & 575.65 & 595,67 & 617,20 & 639,36 \\
\hline 1983. & 714.27 & 728,02 & 799,27 & 967,46 & 970.43 & $1.003,94$ & $1.344,94$ & $1.506,28$ & $2.020,54$ & $2.028,97$ & $2.109,00$ & $2.316,35$ \\
\hline 1984 & 2.567 .93 & $2.819,51$ & 2.844 .87 & 2.765 .77 & 3.491 .15 & 3.512 .52 & 3.873 .55 & $4.594,93$ & $6.418,67$ & $6.654,36$ & $6.864,29$ & 6.932 .67 \\
\hline 1985 & $7.304,41$ & $7.478,69$ & 7.400 .28 & $7.232,(30$ & $7.222,28$ & $7.426,30$ & $11.205,90$ & $15.615,64$ & $16.919,07$ & $20.289,56$ & 27.158 .34 & $29.209,64$ \\
\hline 1986 & 29.436 .02 & $30.036,35$ & $\left.30,016^{\prime}\right)$ & 30,06 & 29.92 & 29,96 & 29,81 & 29,62 & 29,84 & 30.06 & 29,12 & 33,54 \\
\hline 1981 & 72,03 & 64,92 & 63,96 & 69,92 & 94,55 & 91,47 & 119,39 & 134,32 & 128,90 & 145,91 & 172.03 & 165,57 \\
\hline
\end{tabular}

Fonte: Insticuto de Economia Ayricold - IEA.

(') a partir de março de 1986, presus ell $C_{2} s / k, j$. 
Tabela 32. - Preços correntes de carme bovina wecebidus pelus smpermercados da cidade de Säo Paulo, no periodo 1971/87, em Cr\$/kg

\begin{tabular}{|c|c|c|c|c|c|c|c|c|c|c|c|c|}
\hline \multirow{2}{*}{ Ano } & \multicolumn{12}{|c|}{ MESES } \\
\hline & Janl. & Fev. & Mar. & Abr. & Mai. & Jun. & Jul. & Ago. & Sel. & Dut. & Nov. & Dez. \\
\hline 1971 & 4.45 & 4,19 & 4,61 & 4,63 & 4.70 & 4.71 & 4.79 & 4,84 & 5,22 & 5.36 & 5.59 & 5.77 \\
\hline 1972 & 5.37 & 5,68 & 5,97 & 5,83 & 5.75 & 5,70 & 5.74 & 5.66 & 5,75 & 5.78 & 5.86 & 5.82 \\
\hline 1973 & 7,10 & 6,44 & 6,58 & 6.64 & 6,36 & 6.43 & 6,88 & 8.27 & 9,35 & 9.48 & 9,49 & 8.29 \\
\hline 1974 & 7,09 & 7,62 & 7,60 & נו, & 10,97 & 11.05 & 11,37 & 11.52 & 11,65 & 11.57 & 11,74 & 11.76 \\
\hline 1975 & 12,36 & 12,59 & 12,67 & 12,52 & 12,48 & 12,77 & 13,06 & 13,30 & 12,32 & 12.09 & 13,73 & 16,13 \\
\hline 1976 & 16,41 & 16.79 & 16,53 & 16,04 & 15,80 & 15,72 & 15,32 & 15,43 & 15,83 & 15,49 & 15,51 & 15.51 \\
\hline 1977 & 18,16 & 18,57 & 19,27 & 19,28 & 19,08 & 19,33 & 19,12 & 19,27 & 19,19 & 19,98 & 20,07 & 20,69 \\
\hline 1978 & 26,56 & 27.13 & 27,88 & 27.88 & 27,56 & 31,10 & 34,12 & 32,96 & 33.50 & 37.67 & 39,15 & 42,91 \\
\hline 1979 & 48,75 & 49,44 & 50,08 & 48,39 & 48,85 & 49,45 & 62,84 & 65,96 & 76,43 & 77,02 & 83,27 & 90,91 \\
\hline 1980 & 106,80 & 108,33 & 107,52 & 108,69 & 110,65 & 119,99 & 140,83 & 141,22 & 139.17 & 143.75 & 144,98 & 143,11 \\
\hline 1981 & 161,36 & 158,23 & 193,22 & 192,24 & 192,98 & 192,61 & 207.79 & 236,74 & 248,12 & 242,44 & 244.73 & 251,43 \\
\hline 1982 & 258.37 & 275,09 & 289.80 & 307.15 & 323.80 & 349,77 & 451,94 & 479.77 & 495,21 & 514,80 & 527,99 & 533,05 \\
\hline 1983 & $5 \% 6.13$ & 597,82 & 658,67 & 809,35 & 821,38 & 866,36 & $1.193,49$ & $1.324,42$ & $1.744,39$ & $1.801,00$ & $1.851,00$ & 1.970 .00 \\
\hline 1984 & 2.183 .50 & $2.397,00$ & $2.436,00$ & $2.382,00$ & 3.051 .00 & $3.110,00$ & 3.399 .00 & $3.995,00$ & 5.507 .00 & $5.762,00$ & 5.883 .00 & $5.851,00$ \\
\hline 1985 & $6.143,00$ & 6.135 .00 & $6.088,00$ & $6.002,00$ & $5.946,00$ & $6.111,00$ & $9.692,00$ & $13.394,00$ & $14.346,00$ & $16.823,00$ & $21.927,00$ & $23.548,00$ \\
\hline 1986 & $24.187,00$ & 25.099 .00 & $25,20\left(^{\prime}\right)$ & 25,10 & 25,13 & 25,18 & 25,13 & 25,00 & 25,13 & 25,26 & 25,05 & 36.58 \\
\hline 1987 & 57,58 & 53.45 & 53.21 & 57,48 & 76,35 & 75.65 & 92,05 & 100,56 & 88,81 & 109,94 & 127.05 & 131.46 \\
\hline
\end{tabular}

Fonte: Instituto de Economia Agrícola- IEA

(') a partir de março de 1986 preços til Cz\$/kg. 
Tabela 33. Preços médios de carne bovina recebidos pelos varejistas da cidade de Sado Paulo, no períodu 1971/87, ell C, \$/kg

\begin{tabular}{|c|c|c|c|c|c|c|c|c|c|c|c|c|}
\hline \multirow{2}{*}{ Ano } & \multicolumn{5}{|c|}{$\cdot$} & \multicolumn{3}{|c|}{ MESES } & \multirow[b]{2}{*}{ Set. } & \multirow[b]{2}{*}{ Out. } & \multirow[b]{2}{*}{ Nov. } & \multirow[b]{2}{*}{ Dez. } \\
\hline & Jan. & Fev. & Mar. & Abr. & Mai. & Jun. & Jul. & Ago. & & & & \\
\hline 1971 & 4,50 & 4,54 & 4,70 & 4.67 & 4,75 & 4,76 & 4,85 & 4,87 & 5,25 & 5,50 & 5.77 & 5,87 \\
\hline 1972 & 5.91 & 5.96 & 6,00 & 5,95 & 5.97 & 5,90 & 6,06 & 5.69 & 5,76 & 5,86 & 5,89 & 6.19 \\
\hline 1973 & 7,06 & 6.77 & 6,64 & 6,80 & 7.04 & 7,18 & 7,68 & 9,29 & 11,42 & 12,27 & 12.75 & 10,33 \\
\hline 1974 & 7,91 & 8,40 & 8,85 & 11,69 & 11,42 & 11,30 & 11,88 & 11,74 & 12.01 & 11,92 & 12,15 & 12,35 \\
\hline 1975 & 12,84 & 13.52 & 13.75 & 13,68 & 13,82 & 14,09 & 14,36 & 14,28 & 12,64 & 12,47 & 12.96 & 16,78 \\
\hline 1976 & 17,23 & 17,26 & 17.36 & 16,48 & 16.45 & 16,32 & 16,36 & 17,05 & 17.03 & 16,88 & 17,15 & 17,05 \\
\hline 1977 & 20,38 & 21,02 & 20,96 & 21,48 & 21,46 & 21,20 & 22,44 & 22,71 & 22.26 & 23,12 & 25,53 & 27.75 \\
\hline 1978 & 30,81 & 31,15 & 33,42 & 32,28 & 32,36 & 36,04 & 40,22 & 43,08 & 46,74 & 54,09 & 53,98 & 54.90 \\
\hline 1979 & 57,32 & 58,37 & 59.41 & 61,67 & 62,17 & 62,40 & 71,85 & 83,34 & 88,86 & 97,93 & 108,60 & 109,10 \\
\hline 1980 & 117.57 & 113,72 & 112,98 & 116,11 & 120,94 & 124,92 & 146,34 & 151,22 & 159,53 & 177,89 & 173,42 & 175.69 \\
\hline 1981 & 196.51 & 190,24 & 201,30 & 203,41 & 205.93 & 203,49 & 221,60 & 243,51 & 266,52 & 283,86 & 289,82 & 300,39 \\
\hline 1982 & 313,99 & 322,00 & 321,45 & 336,14 & 338,46 & $=374,01$ & 478,05 & 504,29 & 532,49 & 549,79 & 557,69 & 572,82 \\
\hline 1983. & 595,11 & 651,58 & 700,04 & 839,41 & 835,68 & 911.05 & 245,71 & $1.376,50$ & 1.891 .39 & 1.980 .41 & 2.078 .92 & 2.083 .96 \\
\hline 1984 & 2.267 .05 & $2.450,13$ & 2.496 .83 & $2.481,33$ & $3.109,52$ & $3.180,07$ & $3.497,56$ & $4.019,64$ & 5.597 .09 & $5.860,56$ & $5.907,64$ & $5.887,96$ \\
\hline 1985 & 6.259 .27 & $6.221,24$ & $6.305,91$ & 6.263 .03 & $6.197,02$ & $6.296,57$ & $9.889,89$ & 13.464 .07 & 14.738 .70 & $17.295,78$ & 23.076 .61 & $23.926,84$ \\
\hline 1986 & $24.900,79$ & 26.012 .22 & $253.62\left(^{\prime}\right)$ & 25,02 & 24,90 & 25,22 & 25,26 & 25,13 & 27,98 & 30,89 & 36,55 & 55,95 \\
\hline 1987 & 64,53 & 54,96 & 55.60 & 59.72 & 77,80 & 76,60 & 921,16 & 102,45 & 104,59 & 118,90 & 139,81 & 140,45 \\
\hline
\end{tabular}

Fonte: Irsstituto de Economia Agrícola - IEA.

(') a parlir de llarçu de 1986 pregos ell $C z \$ / \mathrm{kg}$. 


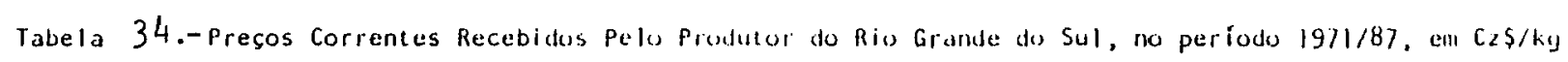

\begin{tabular}{|c|c|c|c|c|c|c|c|c|c|c|c|c|}
\hline \multirow{2}{*}{ Ano } & \multicolumn{8}{|c|}{ MESES } & \multirow[b]{2}{*}{ Set. } & \multirow[b]{2}{*}{ out. } & \multirow[b]{2}{*}{$N o v$. } & \multirow[b]{2}{*}{ Dez. } \\
\hline & Jan. & Fev. & Mar. & $A b r$. & Mai. & Jun. & Jul. & Ago. & & & & \\
\hline 1971 & 2,44 & 2,46 & 2,51 & 2.51 & 2,55 & 2.57 & 2,66 & 2.71 & 2.73 & 2,78 & 2.75 & 2,78 \\
\hline 1972 & 3,14 & 3,29 & 3,22 & 3,30 & 3,32 & 3.33 & 3,42 & 3,44 & 3,58 & 3.67 & 3,76 & 3,89 \\
\hline 1973 & 3.90 & 3,88 & 3.95 & 4,07 & 4,09 & 4,11 & 4,30 & 4.65 & 5,29 & 5.98 & 6,25 & 6.26 \\
\hline 1974 & 6.19 & 6,17 & 6.16 & 6.28 & 6,34 & 6,34 & $6,4,5$ & 6.57 & 6,81 & 7,00 & 7,11 & 7.02 \\
\hline 1975 & 7.10 & 6,93 & 6.72 & 6,61 & 6.71 & 6.77 & 6.82 & 7.26 & 7.55 & 7.83 & 7,93 & 8.08 \\
\hline 1976 & 8,23 & 8,32 & 8,42 & 8,46 & 8,65 & 8.73 & 9.11 & 9.72 & 10,26 & 10,90 & 10.92 & 10.75 \\
\hline 1977 & 11.09 & 11,06 & 11,14 & 11.21 & 11,19 & 11,23 & 11,74 & 12,38 & 13,28 & 13.57 & 14,14 & 14,89 \\
\hline 1978 & 15.03 & 15,35 & 15,67 & 16,135 & 16,27 & 17.09 & 21,41 & 22,41 & 24,27 & 25,78 & 27,87 & 29,70 \\
\hline 1979 & 29,70 & 31.43 & 33,72 & 38,15 & 40,15 & 40,33 & 43,29 & 48,92 & 56,75 & 61,24 & 61,09 & 64.72 \\
\hline 1980 & 64,86 & 65,40 & 66,40 & 68.27 & 70.53 & 74,20 & 85,67 & 96,33 & 96,47 & 104.53 & 107.27 & 107.60 \\
\hline 1981 & 109,07 & 107,93 & 107.87 & 109,27 & 110,00 & 107.87 & 108,60 & 116,33 & 126,53 & 142,60 & 159,00 & 162.27 \\
\hline 1982 & 138,47 & 140,00 & 142,27 & 143,80 & 145,87 & 158,47 & 181,93 & 203,60 & 227.13 & 236,33 & 251.07 & 270.73 \\
\hline 1983 & 246,20 & 258,67 & 276,40 & 319,80 & 340,93 & 373.27 & 456,27 & 575,40 & 878.07 & 936,07 & 1.026 .47 & 1.018 .87 \\
\hline 1984 & $1.053,00$ & $1.146,20$ & 1.274 .33 & $1.358,67$ & 1.453 .53 & 1.579 .93 & 1.967 .00 & $2.254,80$ & 2.731 .60 & $3.250,27$ & 3.411 .13 & 3.393 .07 \\
\hline 1985 & 3.357 .53 & $3.339,93$ & 3.260 .47 & 3.272 .13 & 3.291 .87 & $3.352,53$ & 5.017 .73 & $7.505,33$ & 7.900 .53 & 8.366 .60 & $10.071,80$ & $11.278,87$ \\
\hline 1986 & 11.428 .53 & $12.828,13$ & $13.82(1)$ & 13,59 & 13.77 & 14,17 & 15.12 & 15.96 & $|6,7|$ & 17,18 & 18,87 & 26,26 \\
\hline 1987 & 33,32 & 30,62 & 29.95 & 29.11 & 38,58 & 39.72 & 48.99 & 61,69 & 65,55 & 64,34 & 72,04 & 68,01 \\
\hline
\end{tabular}

Fonte: Fundaçào Getulio Vargas - FGV.

(') a purti, de lliarco de 1986 presos teil C $2 \$ / k g$. 
Tabela 35.-Preços correntes recetidos pelos produtores de bui gordo de Minas Gerais, no periodo $1971 / 87$. ell Cr $\$ / k y$

\begin{tabular}{|c|c|c|c|c|c|c|c|c|c|c|c|c|}
\hline \multirow{2}{*}{ Ano } & \multicolumn{11}{|c|}{ MESES } & \multirow[b]{2}{*}{ Dez. } \\
\hline & Janl. & Fev. & Mar. & Abr. & Mai. & Juri. & Jut. & Augo. & Set. & Out. & Nov. & \\
\hline 1971 & 2,43 & 2,47 & 2,51 & 2,54 & 2,56 & 2.59 & 2,66 & 2,70 & 2,75 & 2,85 & 2,92 & 2,96 \\
\hline 1972 & 3,03 & 3.06 & 3,10 & 3,13 & 3.16 & 3,17 & 3.21 & 3,29 & 3,47 & 3.74 & 3,84 & 3.92 \\
\hline 1973 & 4.07 & 4.07 & 4,07 & 4,17 & 4,23 & 4,24 & 4,44 & 4,95 & 5,86 & 6,57 & 7.20 & 7.14 \\
\hline 1974 & 6,27 & 6,05 & 6.14 & 6,55 & 7,06 & 7,12 & 7,12 & 7,32 & 7,28 & 7,36 & 7,64 & 7.37 \\
\hline 1976 & 7.53 & 7.53 & 7.13 & 6,84 & 6,84 & 6,73 & 6,61 & 6.73 & 6,80 & 6,80 & 7,40 & 7.73 \\
\hline 1976 & 7,73 & 7,86 & 7,93 & 7,86 & 7.93 & 7.97 & 8,16 & 8.42 & 8,86 & 9.23 & 9,62 & 10,04 \\
\hline 1977 & 10,18 & 10,26 & 10,12 & 10,21 & 10,46 & 10,60 & 10,69 & 11.30 & 11,75 & 12,10 & 13,02 & 14.56 \\
\hline 1978 & 15,39 & 16,60 & 16,94 & 17.58 & 17,61 & 19,84 & 20,88 & 23.65 & 25,66 & 27.81 & 31,02 & 31,68 \\
\hline 1979 & 32.98 & 34.32 & 35,3 & 35,90 & 39.22 & 40,06 & 41.96 & 50,85 & 62.46 & 64,25 & 69.40 & 69,40 \\
\hline 1980 & 60,06 & 69,80 & 68,33 & 70,73 & 72,20 & 75,66 & 79,46 & 85,93 & 91.86 & 100.93 & 108,60 & 108,13 \\
\hline 1981 & 109,80 & 107,53 & 108,60 & 108,13 & 109,80 & 104,73 & 106,60 & 113,00 & 121,40 & 129.93 & 137.40 & 145,53 \\
\hline 1982 & 147.60 & 149.86 & 147.26 & 149,33 & 161.73 & 172,86 & 211,80 & 227,53 & 249.13 & 254,80 & 256.53 & 263,20 \\
\hline 1983 & 271.33 & 283.86 & 301,86 & 354,00 & 396,33 & 413,86 & 500,46 & 614,26 & 826,40 & $1.018,93$ & 1.066 .73 & $1.104,80$ \\
\hline 1984 & 1.179 .33 & 1.301 .86 & 1.342 .06 & $1.385,80$ & $1.696,20$ & $1.809,93$ & $1.993,20$ & $2.199,26$ & $2.923,60$ & 3.283 .26 & $3.342,06$ & 3. 348,20 \\
\hline 1985 & 3. 354,60 & $3.370,06$ & $3.353,00$ & 3.381 .06 & $3.434,40$ & $3.456,40$ & 4.641 .93 & 7.064 .66 & $8.117,86$ & $8.905,33$ & $12.699,86$ & 13.168 .53 \\
\hline 1986 & $13.154,20$ & $13.461,60$ & $\left.13.47^{1}\right)$ & 13.63 & 13,83 & 15.34 & 16,87 & 18.41 & 20,06 & 19,50 & 22,21 & 36,28 \\
\hline 1987 & 29,78 & 28.91 & 28,32 & 28.32 & 28.32 & 37,13 & 44,60 & 57,98 & 61,71 & 69.74 & 85.52 & 85.52 \\
\hline
\end{tabular}

Fonte: Fundaçào Getulio Vargas - FGV.

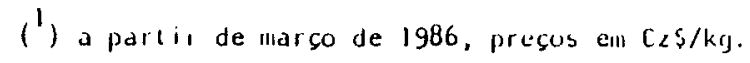


Tabela 36. - Preços correntes recebidos pelos produtores de Goiás, no período 1971/87, ell Cr\$/kg

\begin{tabular}{|c|c|c|c|c|c|c|c|c|c|c|c|c|}
\hline \multirow{2}{*}{ Ano } & \multicolumn{12}{|c|}{ MESES } \\
\hline & Jan. & Fev. & Mar. & Abr. & Mai. & Jun. & Jul. & Ago. & Set. & out. & Nov. & Dez. \\
\hline 1971 & 2,15 & 2,17 & 2,22 & 2,24 & 2,26 & 2,38 & 2,66 & 2.70 & 2,75 & 2,85 & 2,92 & 2,96 \\
\hline 1972 & 2.78 & 2,81 & 2.86 & 2,92 & 2.95 & 2.98 & 3.21 & 3.0 & 3,39 & 3,44 & 3,56 & 3.58 \\
\hline 1973 & 3,81 & 3.98 & 3.98 & 4,05 & 4,06 & 4,08 & 4,34 & 4,80 & 5,46 & 5,79 & 6,28 & 6,24 \\
\hline 1974 & 5,99 & 5,86 & 6,04 & 6,64 & 6,98 & 6.93 & 7,05 & 6.98 & 7,10 & 7,04 & 7,02 & 7,13 \\
\hline 1975 & 6.94 & 6.85 & 6,87 & 6.75 & 6,81 & 6,88 & 6,88 & 6.85 & 6,88 & 7,15 & 7,41 & 7,16 \\
\hline 1976 & 8,12 & 7,81 & 7.65 & 7.82 & 7,90 & 7,73 & 7.73 & 7,96 & 8,39 & 8,68 & 8,68 & 9,02 \\
\hline 1977 & 9,15 & 9.40 & 9.66 & 9,66 & 9,96 & 9,91 & 10,16 & 10.51 & 10,97 & 11,55 & 12,36 & 13,76 \\
\hline 1978 & 14.56 & 14,87 & 15.78 & 16.33 & 16,69 & 17,28 & 19.11 & 20.86 & 23.39 & 25,81 & 26.91 & 29,56 \\
\hline 1979 & 29,42 & 32,36 & 34,17 & 35,96 & 36.71 & 37,61 & 39.49 & 43,19 & 56,42 & 61,13 & 65,74 & 67,36 \\
\hline 1980 & 68,07 & 66,00 & 67,13 & 67.47 & 70.13 & 72,00 & 77,20 & 83.33 & 84,73 & 96,00 & 101,93 & 99,80 \\
\hline 1981 & 102,47 & 98,33 & 97.47 & 100.73 & 102,07 & 98,80 & 98,73 & 105,00 & 111,40 & 121,93 & 134,60 & 135.60 \\
\hline 1982 & 133,93 & 134,53 & 135.93 & 141,40 & 148.47 & 160,67 & 199.13 & 217,20 & 223,07 & 231,93 & 229,20 & 237.07 \\
\hline 1983 & 240,40 & 251,00 & 279.73 & 321.27 & 372,67 & 401,67 & 476,87 & 564,80 & 743,20 & 890,60 & 987.47 & 1.047 .20 \\
\hline 1984 & 1. $12.8,67$ & $1.211,93$ & $1.289 .80 \quad$ & $1.345,07$ & 1.626 .53 & $1.746,93$ & 1.885 .53 & $2.122,67$ & $2.666,00$ & $3.036,53$ & $3.196,86$ & $3.176,00$ \\
\hline 1983 & 3.274 .93 & $3.239,13$ & $3.187 .00 \quad 3$ & $3.227,20$ & 3.229 .13 & $3.231,87$ & 4.621 .13 & 7.000 .40 & 7.740 .27 & $8.835,33$ & $12.046,60$ & 12.733 .27 \\
\hline 1986 & 12.501 .87 & $13.139,40$ & $12,98\left(^{\prime}\right)$ & 13,42 & 13,56 & 14.74 & 15,71 & 17.15 & 17,15 & 18,41 & 19,25 & 20,08 \\
\hline 1987 & 24,92 & 31,48 & 28,32 & 28,89 & 29.39 & 36,37 & 37,0 & 42.73 & 49.52 & 55,46 & 62,60 & 70,98 \\
\hline
\end{tabular}

(1) A partir de março de 1986 preços ell $[z \$ / k !$.

Funte: Fundasáo Getulio Vargas - FGV. 
Tabela 37.-Preços correntes recetidos pelos produtores de Mato Grosso ("), no perído $1971 / 87$, eni $\operatorname{cr} \$ / \mathrm{kg}$

\begin{tabular}{|c|c|c|c|c|c|c|c|c|c|c|c|c|}
\hline \multirow{2}{*}{ Aro } & \multicolumn{12}{|c|}{ MESES } \\
\hline & Jan. & Fev. & Mar. & Alr. & Mai. & Jun. & Jul. & Ago. & set. & out. & Nov. & Dez. \\
\hline 1971 & 2,45 & 2,49 & 2,55 & 2,62 & 2.61 & 2,62 & 2,62 & 2,62 & 2,69 & 2,72 & 2,73 & 2,73 \\
\hline 1972 & 2,97 & 2,99 & 3,03 & 3.00 & 2,99 & 2,99 & 3.14 & 3,16 & 3,23 & 3.29 & 3.46 & 3.51 \\
\hline 1973 & 3,91 & 3,95 & 3,83 & 3,86 & 3.99 & 4,07 & 4,63 & 4,98 & 5,32 & 6,03 & 6,20 & 6,23 \\
\hline 1974 & 6.15 & 6,15 & 6.12 & $6,9 t_{4}$ & 7,49 & 7.53 & 7,47 & 7.36 & 7,31 & 7,43 & 7,42 & 7,54 \\
\hline 1975 & 7.34 & 7.25 & 7.31 & 7.07 & 7.06 & 7.11 & 7.05 & 7,06 & 7.15 & 7,39 & 7,46 & 8,73 \\
\hline 1976 & 8,39 & 8,55 & 8,78 & 8,14 & 8,41 & 8,46 & 8,52 & 9.25 & 9,97 & 10,37 & 10,60 & 10,40 \\
\hline 1977 & 10,42 & 10,30 & 10,35 & 10,70 & 10,87 & 10,80 & 10,92 & 11,61 & 12,06 & 14.57 & 15,26 & 16,34 \\
\hline 1978 & 16,94 & 17,05 & 17,29 & 17.85 & 18,13 & 19.01 & 20,59 & 23,00 & 24,60 & 29.51 & 31.98 & 31,77 \\
\hline 1979 & 33.57 & 33.73 & 35,58 & 36,39 & 37,99 & 39.65 & 42,05 & 50,15 & 61,86 & 67.01 & 69,23 & 68,64 \\
\hline 1980 & 71,77 & 68,10 & 65,87 & 67,20 & 69,37 & 71.30 & 75,33 & 82,43 & 88.67 & 95.17 & 107.40 & 105.63 \\
\hline 1981 & 105.73 & 99,47 & 103,27 & 103,87 & 102,43 & 98,87 & 103,00 & 109,47 & 119.07 & 135,47 & 153,20 & 153,70 \\
\hline 1982 & 150.50 & 144,40 & 142,80 & 143,80 & 149.57 & 158,50 & 181,37 & 212,50 & 237.40 & 240,83 & 235,67 & 242.33 \\
\hline $1983^{\circ}$ & 244,10 & 250,87 & 278,70 & 320,07 & 388.30 & 408,83 & 475,10 & 548,23 & 702.47 & 949.90 & 1.037 .73 & 1.097 .73 \\
\hline 1984 & 1.132 .37 & $1.222,33$ & $1.291,13$ & $1.330,13$ & $1.477,83$ & $1.727,97$ & $1.900,80$ & $2.093,43$ & $2.769,20$ & $3.190,43$ & 3.345 .53 & $3.369,40$ \\
\hline 1985 & 3.500 .60 & 3.424 .67 & 3.314 .93 & 3.369 .87 & 3.392 .73 & $3.392,60$ & $4.367,00$ & $6.190,40$ & 7.620 .13 & $9.895,20$ & 12.671 .47 & 13.443 .66 \\
\hline 1986 & $12.629,80$ & $13.122,77$ & $13,52\left(^{\prime}\right)$ & 13.66 & 13.97 & 14,80 & 15,66 & 16,49 & 19.05 & 19,08 & 19,88 & 26,01 \\
\hline 1987 & 35.25 & 30,41 & 29.38 & 29,49 & 37,86 & 37.90 & 45,94 & 53,81 & 58,45 & 63,98 & 73,66 & 72.59 \\
\hline
\end{tabular}

Fonte: fundasáu Getulio Vargas - FGV.

(*) a partir de janeiro de 1980 corresponde a media de Mato Grosso e Mato Grosso do Sul.

(') a paltir de marşo de 1986 preşos ell $C_{2} \$ / k y$. 


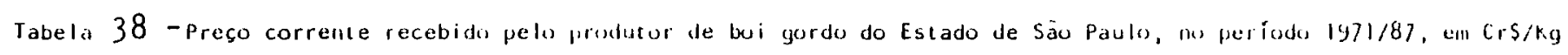

\begin{tabular}{|c|c|c|c|c|c|c|c|c|c|c|c|c|}
\hline \multirow{2}{*}{ Ano } & \multicolumn{12}{|c|}{ MESES } \\
\hline & Jan. & Fev. & Mar. & Alor. & Mai. & Jun. & Jul. & Ago. & Set. & Out. & Nov. & Dez. \\
\hline 1971 & 2,59 & 2,64 & 2,67 & $2 ; 68$ & 2,13 & 2.78 & 2,80 & 2.84 & 2,89 & 3,04 & 3,13 & 3,20 \\
\hline 1972 & 3,25 & 3,31 & 3,34 & 3.64 & 3,38 & 3,35 & 3,37 & 3.40 & 3.76 & 4.15 & 4,21 & 4,25 \\
\hline 1973 & 4,39 & 4,26 & 4,19 & 4,20 & 4,26 & 4,31 & 4,45 & 5,16 & 6,48 & 7.52 & 7.75 & 6.97 \\
\hline 1974 & 6,10 & 6,06 & 6,29 & 7.55 & 7,44 & 7,02 & 7,39 & 7,58 & 7,47 & 7,52 & 7.63 & 7.77 \\
\hline 1975 & 7,72 & 7.56 & 7,35 & 7.18 & 7,26 & 7.15 & 7.10 & 7.41 & 7,38 & 8,01 & 8,97 & 8.86 \\
\hline 1976 & 8,82 & 8,73 & 9,10 & 9,12 & 8,93 & 8,95 & 9.06 & 9.84 & 9,93 & 10,37 & 10.73 & 10,39 \\
\hline 1977 & 10,71 & 10,93 & 11,18 & 11,22 & 11,32 & 11,31 & 11.99 & 13,02 & 15,03 & 16,80 & 17.73 & 17,79 \\
\hline 1978 & 17.82 & $\mid 8,0\}$ & 18,35 & 18,50 & 18,61 & 19,36 & 24,05 & 25,43 & 27.15 & 33.49 & 34,19 & 34,41 \\
\hline 1979 & 35,25 & 36,11 & 36,92 & 39,31 & 40,29 & 40,96 & 44,71 & 51,65 & 66,63 & 69,07 & 72,47 & 70,08 \\
\hline 1980 & 72,76 & 70,11 & 69,32 & 71,24 & 73.70 & 75.65 & 83.31 & 91,82 & 94,97 & 113,01 & 115,82 & 110,06 \\
\hline 1981 & 111,31 & 110,24 & 110.31 & 110,58 & 125,06 & 107,15 & 112,74 & 122,85 & 145,46 & 159,55 & 170.71 & 167,86 \\
\hline 1982 & 165,98 & 159,60 & 158.58 & 162.99 & 174.75 & 183,91 & 243.05 & 258,43 & 210,47 & 270,18 & 271,26 & 273,81 \\
\hline 1983 & 282,90 & 294,93 & 332,50 & 429,11 & $4,49.55$ & 468,26 & 631,15 & 736,13 & 1.027 .00 & 1.135 .67 & 1.182 .60 & $1.219,67$ \\
\hline 1984 & $1.302,00$ & $1.408,07$ & $1.446,00$ & 1.483 .33 & 1.871 .80 & 1.972 .67 & 2.219 .67 & $2.528,67$ & $3.488,67$ & 3.649 .33 & $3.638,67$ & 3.620 .67 \\
\hline 1985 & 3.696 .67 & $3.534,67$ & $3.492,00$ & $3.538,00$ & 3.551 .33 & 3.556 .00 & $5.452,67$ & $7.664,67$ & $8.951,33$ & $10.290,00$ & $13.650,00$ & 13.973 .53 \\
\hline 1986 & 14.126 .00 & $14.276,67$ & $14,20\left(^{1}\right)$ & 14,27 & 14,60 & 15,85 & 17.24 & 18,92 & 21,98 & 19,50 & 26,04 & 36.99 \\
\hline 1987 & 36,19 & 31,59 & 30.50 & 31,17 & 40.89 & 41,09 & 50,80 & 60,81 & 64,44 & 69.37 & 83.24 & 74.69 \\
\hline
\end{tabular}

Funce: Instituto de Economia Ayficola - IEA

(') a partir de marso de 1986 preços ell $C_{<} \$ / \mathrm{kg}$. 
APENDICE 2 
Tabela 39. - Efeitos de um choque de uma unidade de desvio padrão em PSP sobre o sistema PSP-V-A ( $\left.{ }^{1}\right)$

\begin{tabular}{|c|c|c|c|}
\hline Meses & PSP & V & A \\
\hline 1 & 1.00000 & .790201 & .675060 \\
\hline 2 & 1.11921 & .958556 & .812847 \\
\hline 3 & 1.00601 & .846163 & .690448 \\
\hline 4 & .920900 & .753463 & .652041 \\
\hline 5 & .871024 & .697113 & .657627 \\
\hline 6 & .74 .5996 & .600079 & .586975 \\
\hline 7 & .621294 & .454908 & .466489 \\
\hline 8 & .509596 & .388163 & .343546 \\
\hline 9 & .638335 & .3938 .58 & $.51=234$ \\
\hline 10 & .569517 & .261843 & .396772 \\
\hline 11 & .541665 & .580913 & .400824 \\
\hline 12 & .531819 & .253557 & $.37583:$ \\
\hline 13 & .452554 & .568897 & .433708 \\
\hline 14 & .441258 & $.30835=$ & .490846 \\
\hline 1.5 & .4061 .58 & .323183 & .526960 \\
\hline 16 & .301836 & .276380 & .479915 \\
\hline 17 & .229286 & .237337 & .458359 \\
\hline 18 & .160755 & .186337 & .368236 \\
\hline 19 & .105997 & $.1780=5$ & .300951 \\
\hline 20 & $.701406 E-00$ & $.773705 E-01$ & .165397 \\
\hline 21 & $-.385324 E-01$ & $.5019 \Omega E E-01$ & $.866677 \mathrm{E}-01$ \\
\hline$\Xi 2$ & $-.831278 E-01$ & $.116 .578 E-01$ & $.321092 E-01$ \\
\hline$\therefore 3$ & $-.960922 \mathrm{E}-01$ & $-.651109 \mathrm{E}-0 \mathrm{~S}$ & $.159666 E-01$ \\
\hline 24 & -.127339 & $-.533774 E-01$ & $.586254 E-02$ \\
\hline 25 & -.149867 & $-.357749 \mathrm{E}-01$ & $.15117 \Xi 5-01$ \\
\hline$=5$ & -.170347 & $-.514844 E-01$ & $.239066 \mathrm{E}-01$ \\
\hline 37 & -.1919 .54 & $-.575503 E-01$ & $.292785 \mathrm{E}-01$ \\
\hline 28 & -.299500 & $-.800847 E-01$ & $.176165 \mathrm{E}-0 \Omega$ \\
\hline 39 &.- .43617 & $-.837041 E-01$ & $-.195713 \mathrm{E}-01$ \\
\hline 30 & -.275305 & -.111188 & $-.672008[-01$ \\
\hline 31 & -.982178 & -.150045 & $-.958587 \mathrm{~L}-01$ \\
\hline 35 & -.288120 & -.136035 & -.130350 \\
\hline 33 & -.287703 & -.148650 & $-.1530=0$ \\
\hline 34 & -.280297 & -.156087 & -.163537 \\
\hline 3.5 & -.263840 & -.154069 & -.159162 \\
\hline $3 \leq$ & -.549901 & -.149 .579 & $-.15177 \%$ \\
\hline 37 & -.030681 & -.139488 & -.136735 \\
\hline 38 & -.219940 & -.134761 & -.132560 \\
\hline 39 & -.203239 & -.155611 & -.125818 \\
\hline 40 & -.192179 & -.119645 & -.125185 \\
\hline 41 & -.179400 & -.113012 & -.127504 \\
\hline 45 & -.167984 & -.111454 & -.134168 \\
\hline 43 & -.152198 & -.10805 .5 & -.137458 \\
\hline 44 & -.136091 & -.103737 & -.138093 \\
\hline 45 & -.11 .5707 & $-.960080 \mathrm{E}-01$ & -.132086 \\
\hline 46 & $-.958918 \mathrm{E}-01$ & $-.877436 \mathrm{E}-01$ & -.123931 \\
\hline 47 & $-.744560 \mathrm{E}-01$ & $-.754585 \mathrm{E}-01$ & -.109375 \\
\hline 48 & - . .5.5488อE-01 & $-.6461 .55 E-01$ & $-.954563 I-01$ \\
\hline
\end{tabular}

(') PSP, V e A referem-se aos preços recebidos pelos produtores do Estado de São Paulo, varejo e atacado, respectivamente. 
Tabela 40.- Efeitos de um choque de uma unidade de desvio padrão em $V$ sobre o sistema PSP $-V-A\left(^{1}\right)$

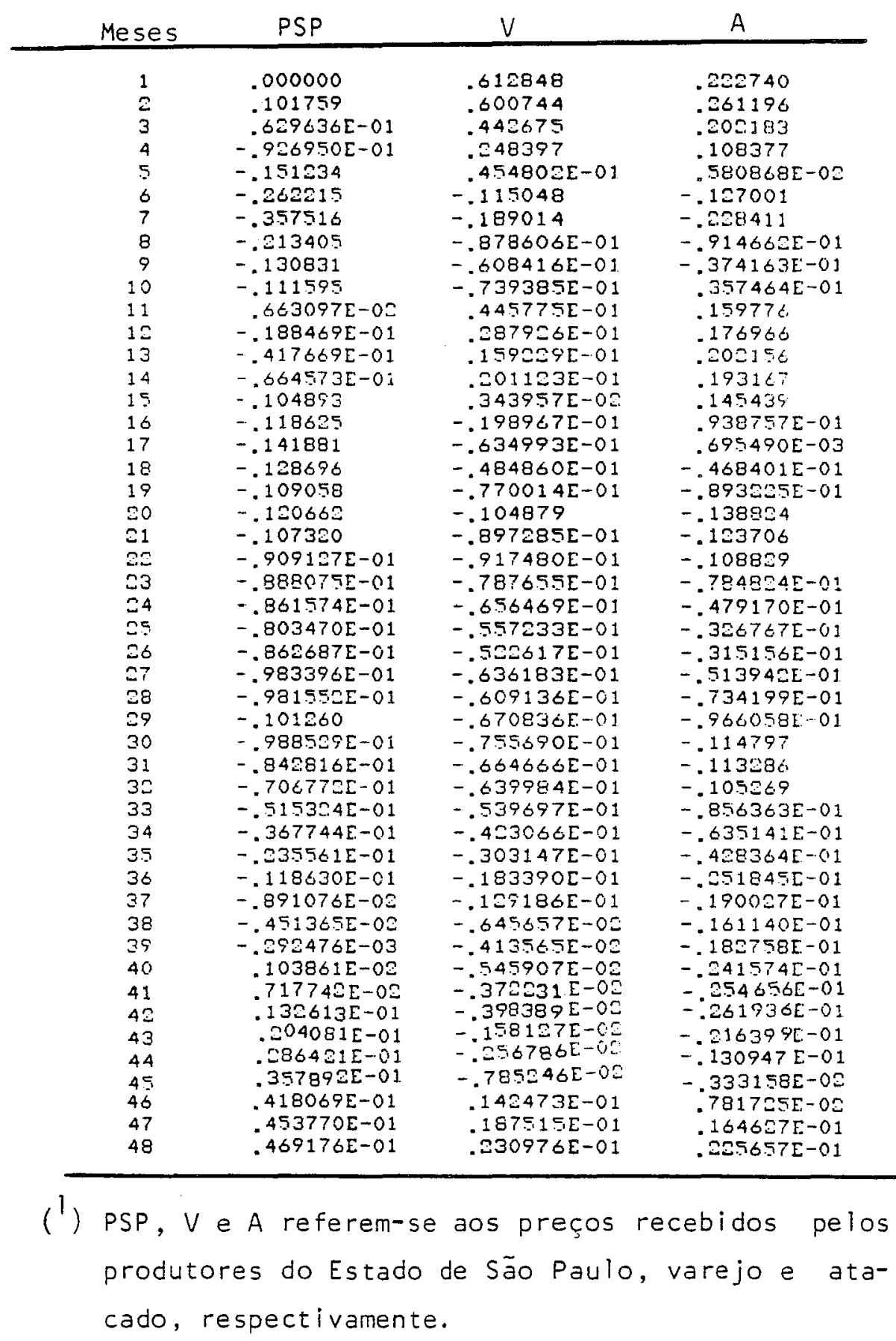


Tabela 41.-Efeitos de um choque de uma unidade de desvio padrão em A sobre o sistema PSP$-V-A(1)$

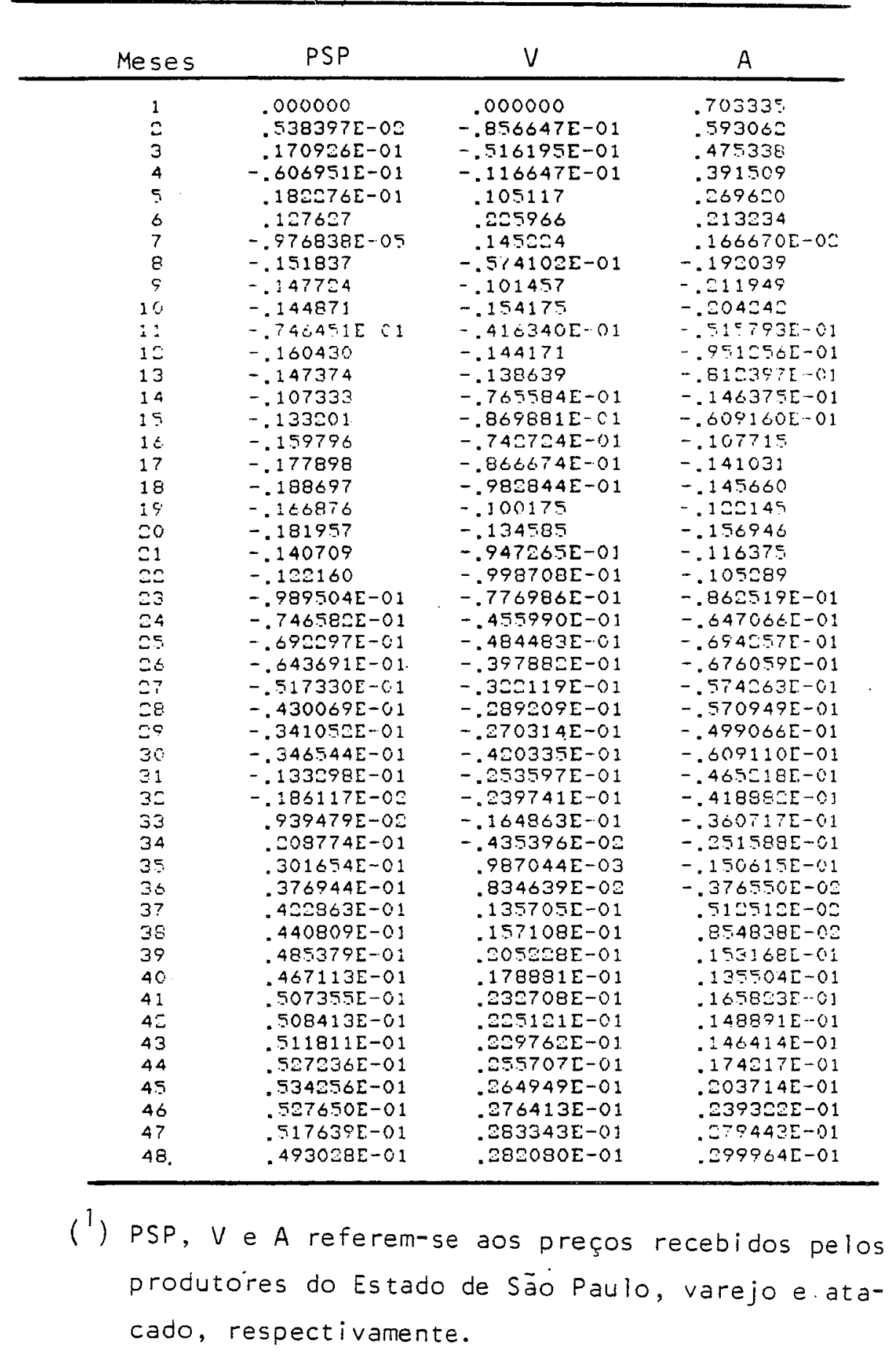


Tabela 42. - Efeitos de um choque de uma unidade de 171. desvio padrão em PMT sobre o sistema PMT-V-A ${ }^{1}{ }^{1}$ )

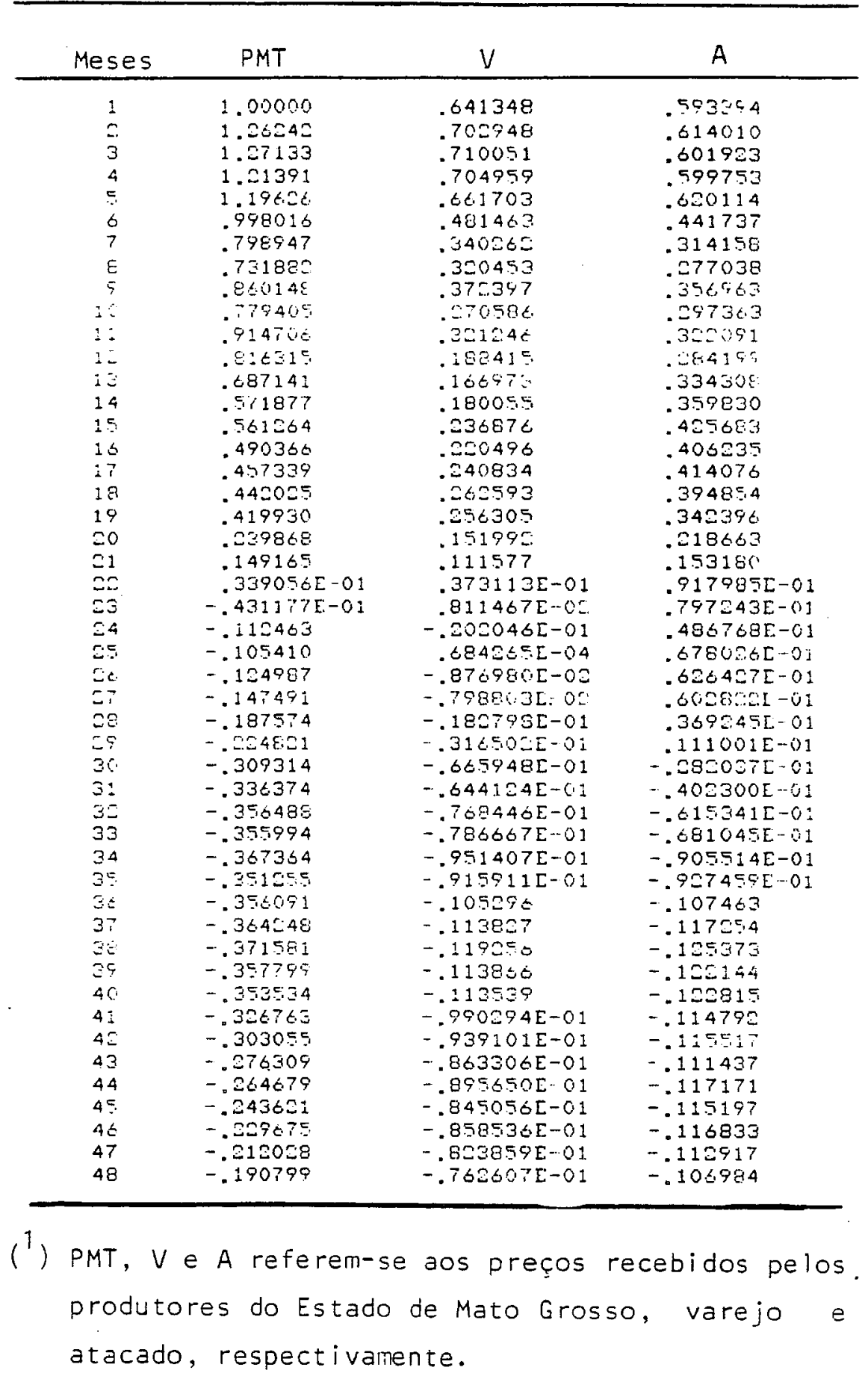


Tabela 43. - Efeitos de um choque de uma unidade de desvio padrão em $V$ sobre o sistema PMT $-\mathrm{V}-\mathrm{A}\left({ }^{1}\right)$

\begin{tabular}{|c|c|c|c|}
\hline Meses & PMT & V & A \\
\hline 1 & .000000 & .767250 & .370397 \\
\hline 2 & .495420 & .864004 & .533984 \\
\hline 3 & .413731 & .644668 & .402064 \\
\hline 4 & .354895 & .440176 & .330545 \\
\hline 5 & .197753 & .524980 & .505079 \\
\hline 6 & $.143344 E-01$ & .107341 & .136 .594 \\
\hline 7 & -.596739 & $-.459483 E-01$ & $-.323688 E-01$ \\
\hline 8 & -.250333 & $-.196061 \mathrm{~L}-01$ & $-.310160 \mathrm{C}-01$ \\
\hline 9 & -.125934 & $-.640831 \mathrm{E}-0 \mathrm{I}$ & $.963824[-0]$ \\
\hline 10 & $-.457247 E-01$ & $-.5 \% 1288 E-01$ & $.733501-01$ \\
\hline 11 & $-.133079 \mathrm{E}-01$ & $.111256 E-01$ & .146 .555 \\
\hline 12 & $.575816 E-01$ & $.931839 \mathrm{~L}-01$ & .205054 \\
\hline 13 & $-.280113[-01$ & $.498337 E-01$ & .188038 \\
\hline 14 & $-.712126 E-01$ & $.598400 E-01$ & .217577 \\
\hline 15 & -.118318 & $.310007 E-01$ & .178818 \\
\hline 16 & -.152554 & $.382341 E-01$ & .156454 \\
\hline 17 & -.200155 & $.8780515-00$ & $.902480 E-01$ \\
\hline 18 & -.197437 & 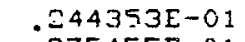 & $.2813135-01$ \\
\hline 19 & -.173543 & $.2754 .55 \mathrm{E}-01$ & $-.166604 \mathrm{E}-02$ \\
\hline$=0$ & -.21067. & $-.537605 E-01$ & $-.801947 E-01$ \\
\hline$=1$ & $-.985: 18$ & -.111079 & -.138485 \\
\hline $2 \pi$ &. .287963 & -.119406 & $=.135987$ \\
\hline 33 & -.328418 & -.143619 & -.140735 \\
\hline 54 & -.320343 & -.1187 .57 & -.109209 \\
\hline 55 & - . 295590 & -.100958 & $-.865740 E-01$ \\
\hline 26 & $-.23338 \%$ & $-.688500 \mathrm{~L} \cdot 01$ & $-.576282[-01$ \\
\hline 57 & -.226475 & $-.646003[-01$ & $-.545 .537 E-01$ \\
\hline 28 & - MN1300 & $-.577546 E-01$ & $-.680120 \mathrm{E}-01$ \\
\hline 98 & -.20124 & $-.5975095-01$ & $-.8109635-01$ \\
\hline $3 \hat{0}$ & $-.2553 \pm 1$ & $-.687079 E-01$ & $-.986633 \mathrm{E}-01$ \\
\hline 31 & -.354805 & $-.846971 \mathrm{E}-01$ & -.116089 \\
\hline 30 & -.397825 & $-.757800 \mathrm{O}-01$ & -.107962 \\
\hline 33 & - . 209276 & $-.804964 E-01$ & -.105960 \\
\hline 34 & -.179370 & $-.700181 \mathrm{E}-01$ & $-.948446 E-01$ \\
\hline 35 & -.152312 & $-.631 .5 \mathrm{~s}-7 \mathrm{E}-01$ & $-.857308 \mathrm{E}-01$ \\
\hline 36 & $-.1170 \% 5$ & $-.519830 E-01$ & $-.734786 \mathrm{E}-01$ \\
\hline 37 & $\cdots .107384$ & $-.5551 .57 \mathrm{E}-0 \mathrm{~J}$ & $-.693975 E-01$ \\
\hline 35 & $-.983046 E-01$ & $-.484343 E-01$ & $-.049670 \mathrm{E}-01$ \\
\hline 39 & $-.844115 E-01$ & $-.394577 \mathrm{E}-01$ & $-.588921 \mathrm{E}-01$ \\
\hline 40 & $-. \Delta \leq \varepsilon 42 \pm E-C 1$ & $-.300710 E-01$ & $.492497 I-01$ \\
\hline 41 & $-.54181 .5 E-01$ & $-.247041 \mathrm{E}-01$ & $-.450972[-01$ \\
\hline $4 ?$ & $-.260650 E-01$ & $-.1=3345 E-01$ & $-.354865 I-01$ \\
\hline 43 & $-.748804 \mathrm{E}-0 \mathrm{E}$ & $-.105990 \mathrm{E}-01$ & $-.324873 E-01$ \\
\hline 44 & $.706027 E-02$ & $-.833817 E-0 \Omega$ & $-.295143 E-01$ \\
\hline 45 & $.143316 E-01$ & $-.867869 \mathrm{E}-02$ & -. . $79828 \mathrm{E}-01$ \\
\hline 46 & $.231428 E-01$ & $-.550800 E-02$ & -. $331288 \mathrm{E}-01$ \\
\hline 47 & $.312014 \mathrm{E}-01$ & $-.531569 \mathrm{E}-02$ & $-.194114 E-01$ \\
\hline 48 & $.401336 \mathrm{E}-01$ & $-.665963 \mathrm{E}-03$ & $-.118960 \mathrm{E}-01$ \\
\hline
\end{tabular}

(1) PMT, V e A referem-se aos preços recebidos pelos produtores do Estado de Mato Grosso, varejo e atacado, respectivamente. 
Tabela 44.- Efeitos de um choque de uma unidade de desvio Dadrão em A sobre o sistema PMT$-V-A\left({ }^{1}\right)$

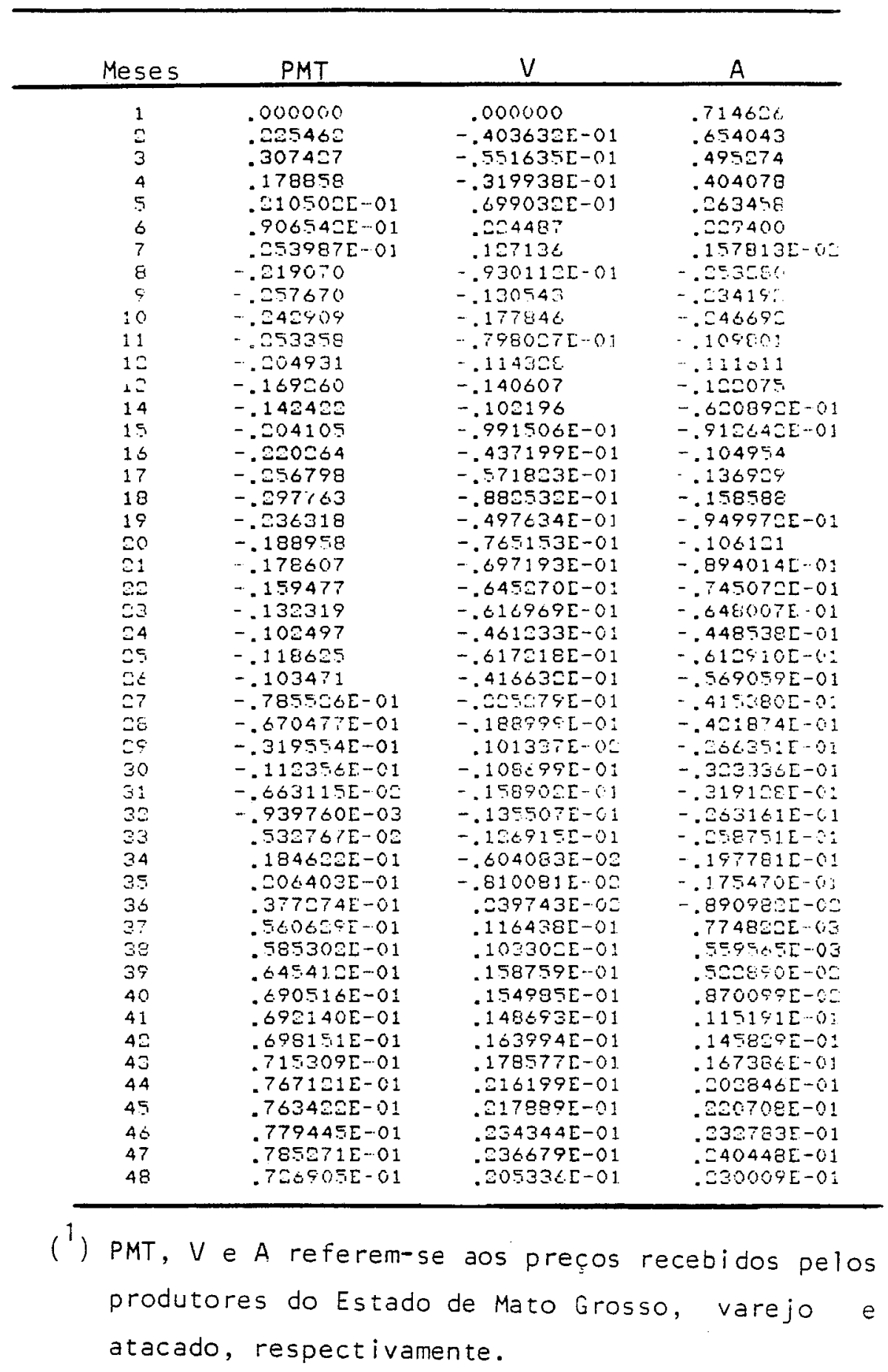


Tabela 45.-Efeitos de um choque de uma unidade de desvio padrão em PGO sobre o sistema PGO$-V-A(1)$

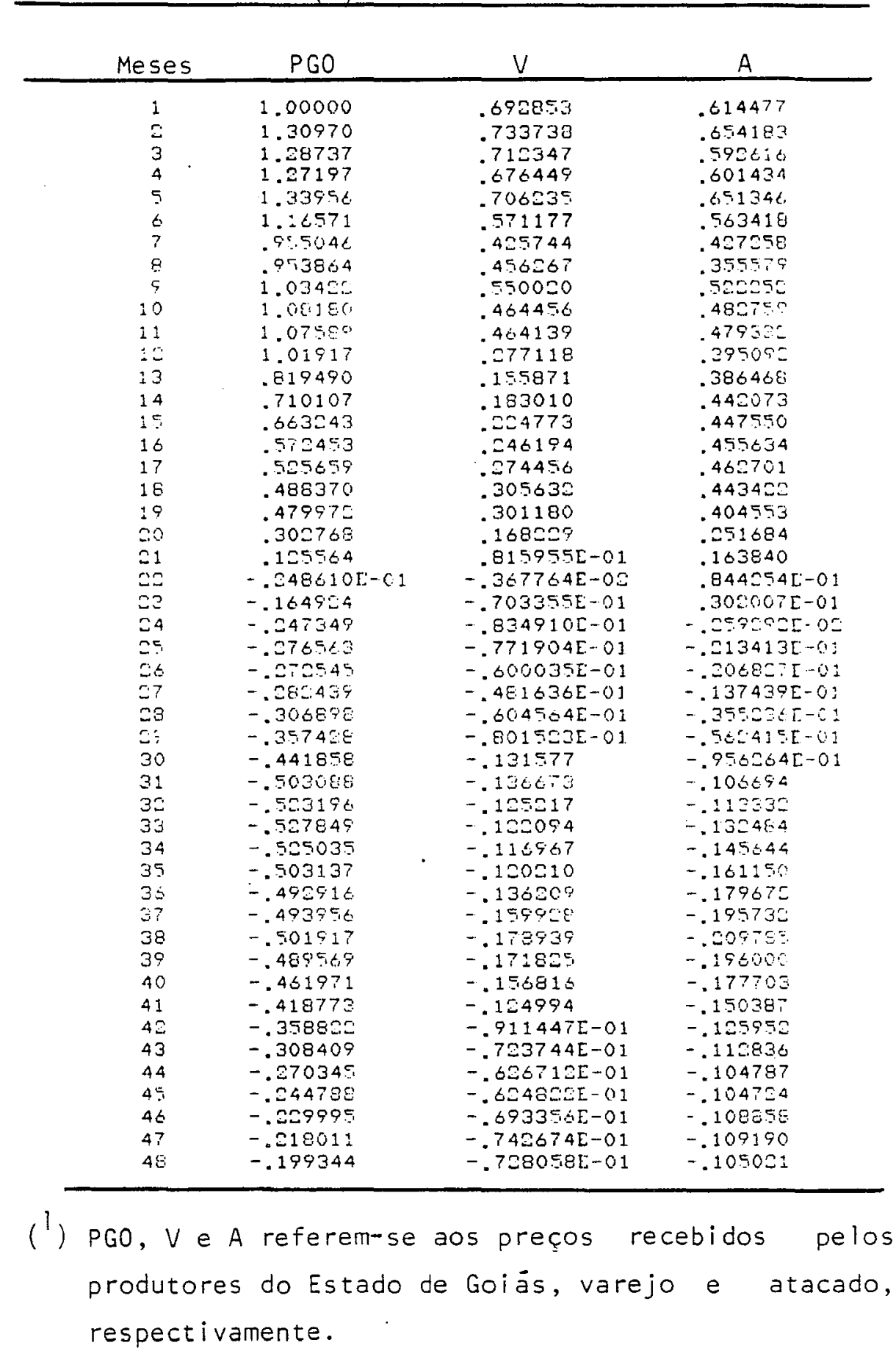


Tabela 46. - Efeitos de um choque de uma unidade de desvio padrão em $V$ sobre o sistema PGO$-V-A(1)$

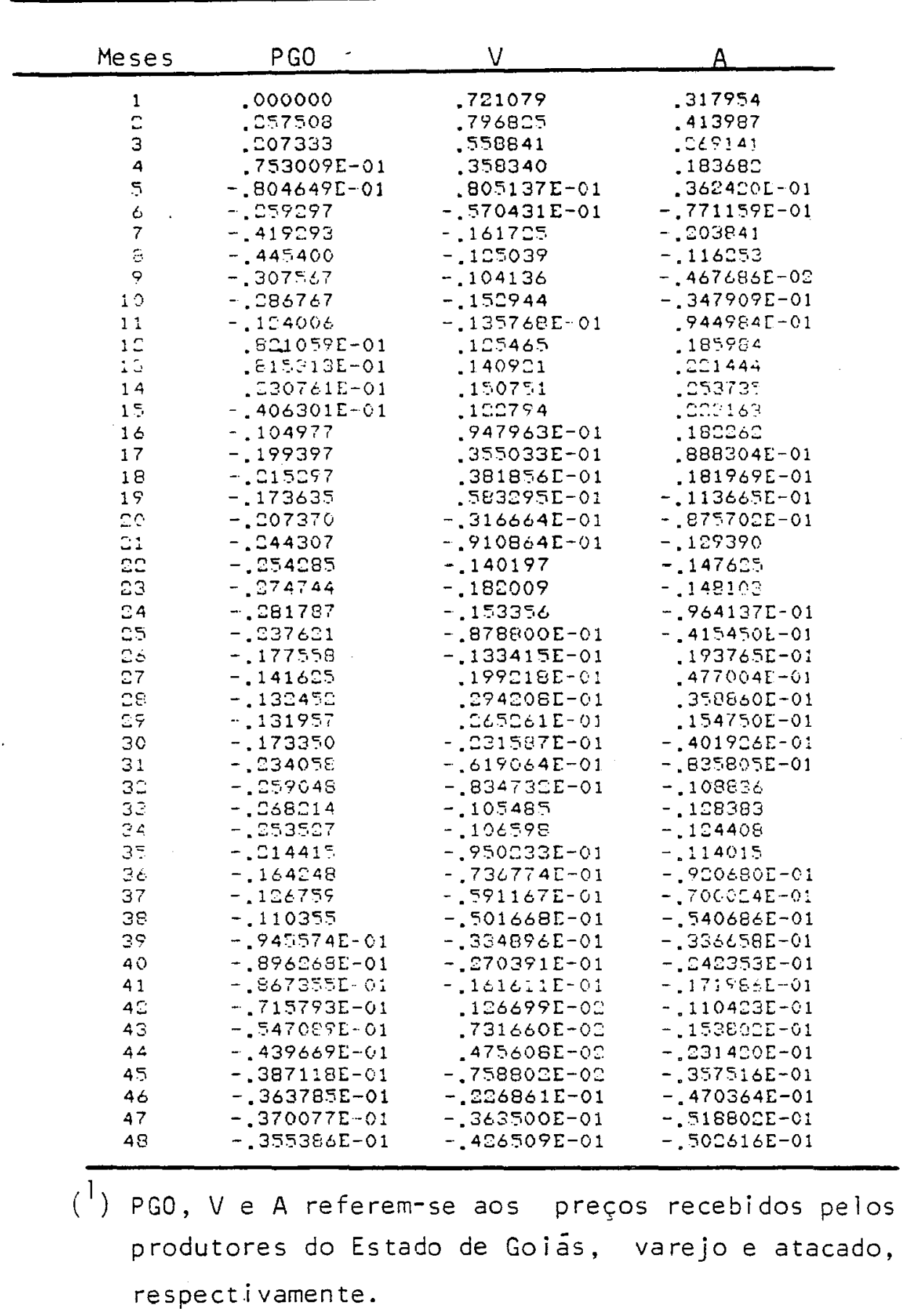


Tabela 47.-Efeitos de um choque de uma unidade de desvio padrão em A sobre o sistema PGO$-V-A\left({ }^{l}\right)$

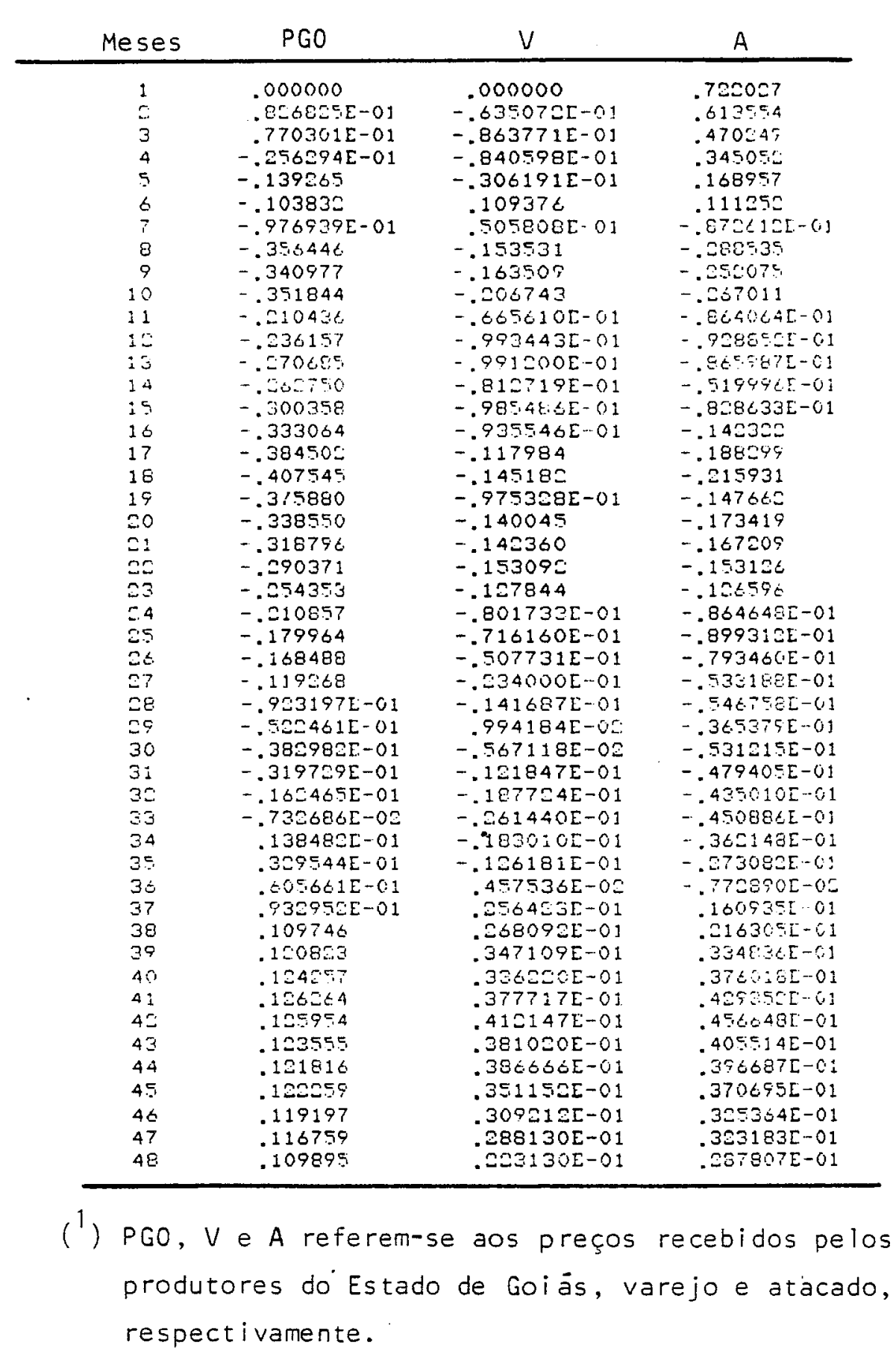


Tabela 48.- Efeitos de um choque de uma unidade de desvio padrão em PMG sobre o sistema PMG $-V-A\left({ }^{1}\right)$

\begin{tabular}{|c|c|c|c|}
\hline Meses & PMG & V & $A$ \\
\hline 1 & 1.00000 & $.629 \leq 24$ & $5 \div 9701$ \\
\hline$\Xi$ & 1. 26904 & .688 .563 & .572047 \\
\hline 3 & 1.24181 & .630037 & .474593 \\
\hline 4 & $1.13=0=$ & .498747 & .447789 \\
\hline 5 & 1.16349 & .576615 & .54375 \\
\hline 6 & .981993 & $.558=01$ & $.4 i>01 B$ \\
\hline 7 & .836119 & .440321 & .384133 \\
\hline$E$ & .884294 & .520376 & .384156 \\
\hline 5 & .980478 & .517194 & $.578-48=$ \\
\hline 10 & .923866 & .347268 & $.44 t A=$ \\
\hline 11 & .679034 & .295429 & .430077 \\
\hline 15 & .506080 & .165210 & .307007 \\
\hline 13 & .351175 & $.936635 \mathrm{E}-01$ & $.80078=$ \\
\hline 14 & .303430 & .156033 & $.0035=5$ \\
\hline 15 & .339054 & .907535 & .316491 \\
\hline 16 & .358790 & .202105 & .3441 .5 \\
\hline 17 & .360367 & .198853 & .340588 \\
\hline 18 & .3470 .56 & .162650 & .328394 \\
\hline 19 & .373390 & .162929 & .298644 \\
\hline 50 & $.858594 E-01$ & $.835 \Omega 44 \Sigma-0 I$ & .204835 \\
\hline$\approx 1$ & $.456170 E-01$ & $.981000 E-01$ & .176717 \\
\hline 35 & $.397477 E-01$ & .113485 & .179150 \\
\hline 53 & $.456383 E-01$ & .111271 & .140867 \\
\hline 84 & $.190297 E-01$ & $.775714 E-01$ & .101997 \\
\hline 5.5 & $-.347606 E-05$ & $.45: 167 E-01$ & $.68797=E-01$ \\
\hline $2 \leq$ & $-.453586 \mathrm{E}-01$ & $.805834 \mathrm{E}-0 \mathrm{~S}$ & $.360046[-0]$ \\
\hline 57 & -.123556 & $-.4446 E 4 E-01$ & $.131103 E-05$ \\
\hline$\therefore \varepsilon$ & -.177833 & $-.563118 E-01$ & $-.38 \equiv 55 \mathrm{E}-01$ \\
\hline nq & -.182470 & $-.403478 E-01$ & $-.004375 E-01$ \\
\hline 30 & -.136067 & $-.277469[-01$ & $-.1107 E 4 E-C 1$ \\
\hline 31 & -.107590 & $-.135015 E-01$ & $.506645 E-05$ \\
\hline 30 & $-.843603 \mathrm{E}-01$ & $-.121353 E-01$ & $.5 \in 17815-0=$ \\
\hline 33 & $-.988535 E-01$ & $-.351515 E-01$ & -.1028965 . \\
\hline 34 & -.128489 & $-.4971=5[-01$ & - . $50031[-01$ \\
\hline 35 & -.149625 & $-.535568 E-01$ & $-.3935775-01$ \\
\hline 36 & -.157543 & $-.504756 E-01$ & $-.451487[-01$ \\
\hline 37 & -.147991 & $-.397214 \mathrm{E}-01$ & $-.475655[-0]$ \\
\hline 38 & -.125753 & $-.375744[-01$ & $-.436501[-01$ \\
\hline 39 & $-.970478 E-01$ & $-.311035 \mathrm{E}-01$ & $-.391557[-01$ \\
\hline 40 & $-.1028 \mathrm{es}$ & $-.454778 E-01$ & $-.477099 E-0 \pm$ \\
\hline 41 & -.118270 & $-.601005 \mathrm{E}-\hat{\mathrm{S}}$ & $-.6 \Omega 1741 \mathrm{E}-01$ \\
\hline 40 & -.133590 & $-.656118 E-01$ & $-.679365 \mathrm{E}-01$ \\
\hline 43 & -.135209 & $-.619903 \mathrm{E}-01$ & $-.6846762-01$ \\
\hline 44 & -.12 .5990 & $-.537190 \mathrm{~L}-01$ & $-.644575 \mathrm{E}-01$ \\
\hline 45 & -.108014 & $-.448717 E-01$ & $-.570433 E-01$ \\
\hline 46 & $-.847680 I-01$ & $-.367135 \mathrm{E}-01$ & $-.501358 E-01$ \\
\hline 47 & $-.724711 E-01$ & $-.380291 \mathrm{E}-01$ & $-.446188 \Gamma-01$ \\
\hline 48 & $-.755714 E-01$ & $-405606 E-01$ & $-.490919[-01$ \\
\hline
\end{tabular}

$(1)$

PMG, $V$ e A referem-se aos preços recebidos pelos produtores do Estado de Minas Gerais, varejo e atacado, respectivamente. 
Tabela 49.- Efeitos de um choque de uma unidade de desvio padräo em $V$ sobre o sistema $P M G$ $-V-A \quad\left(^{1}\right)$

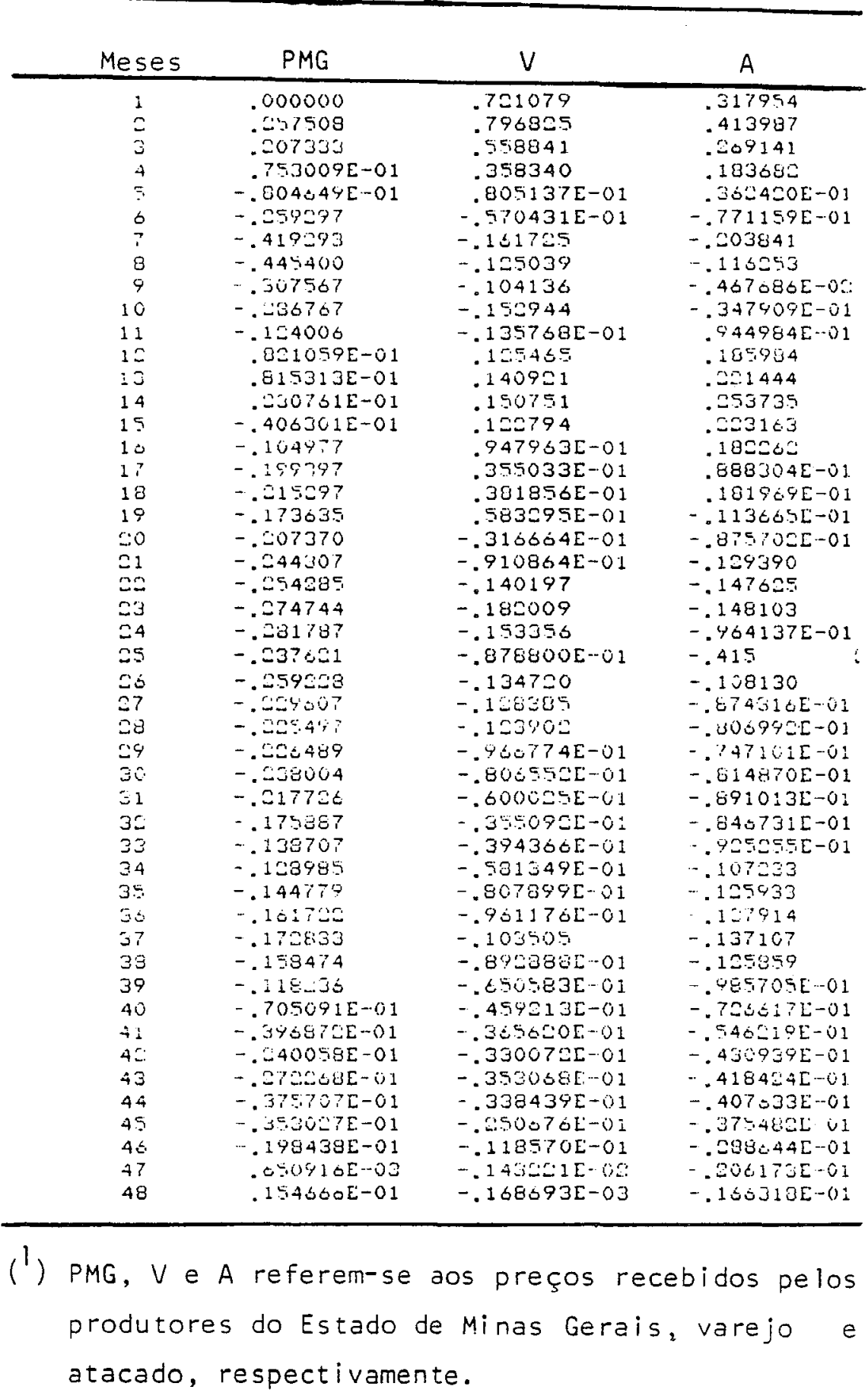


Tabela 50.- Efeitos de um choque de uma unidade de desvio padrão em $A$ sobre o sistema $P M G$ $-V-A\left({ }^{1}\right)$

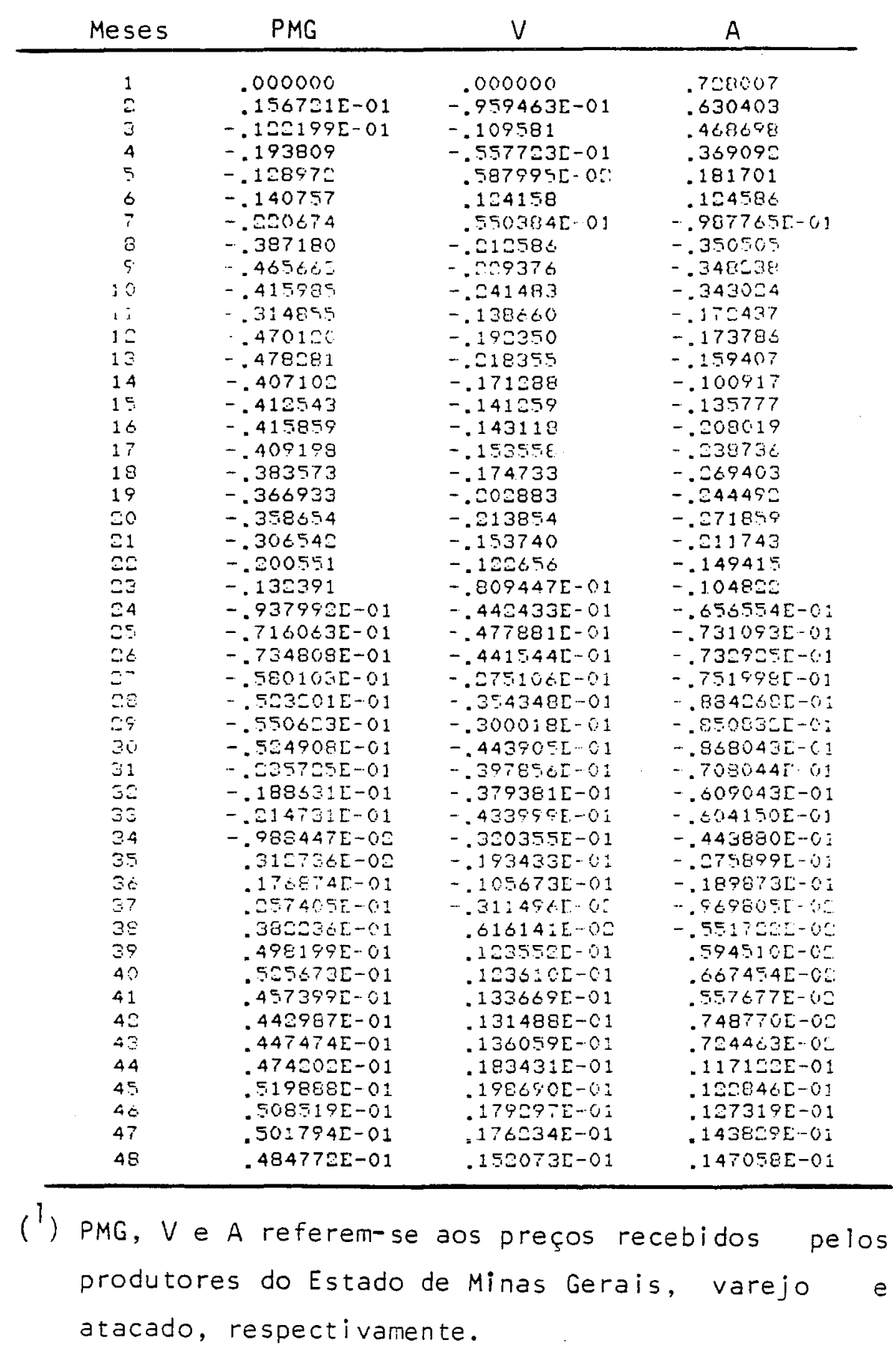


Tabela 51. - Efeitos de um choque de uma unidade de desvio padrão em PRS sobre o sistema PRS$-V-A()$

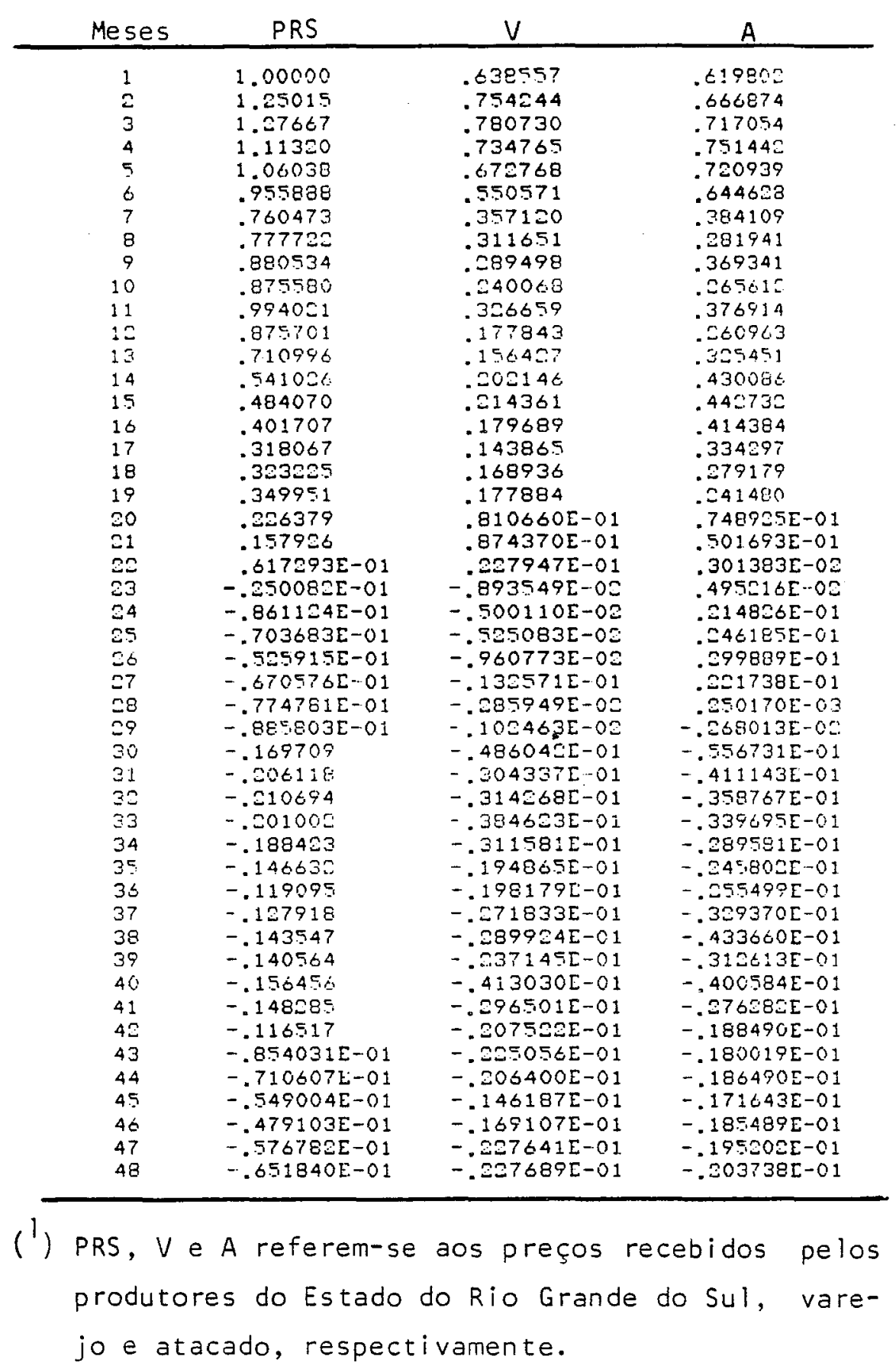


Tabela 52. - Efeitos de um choque de uma unidade de desvio padrão em $V$ sobre o sistema PRS$-V-A\left({ }^{1}\right)$

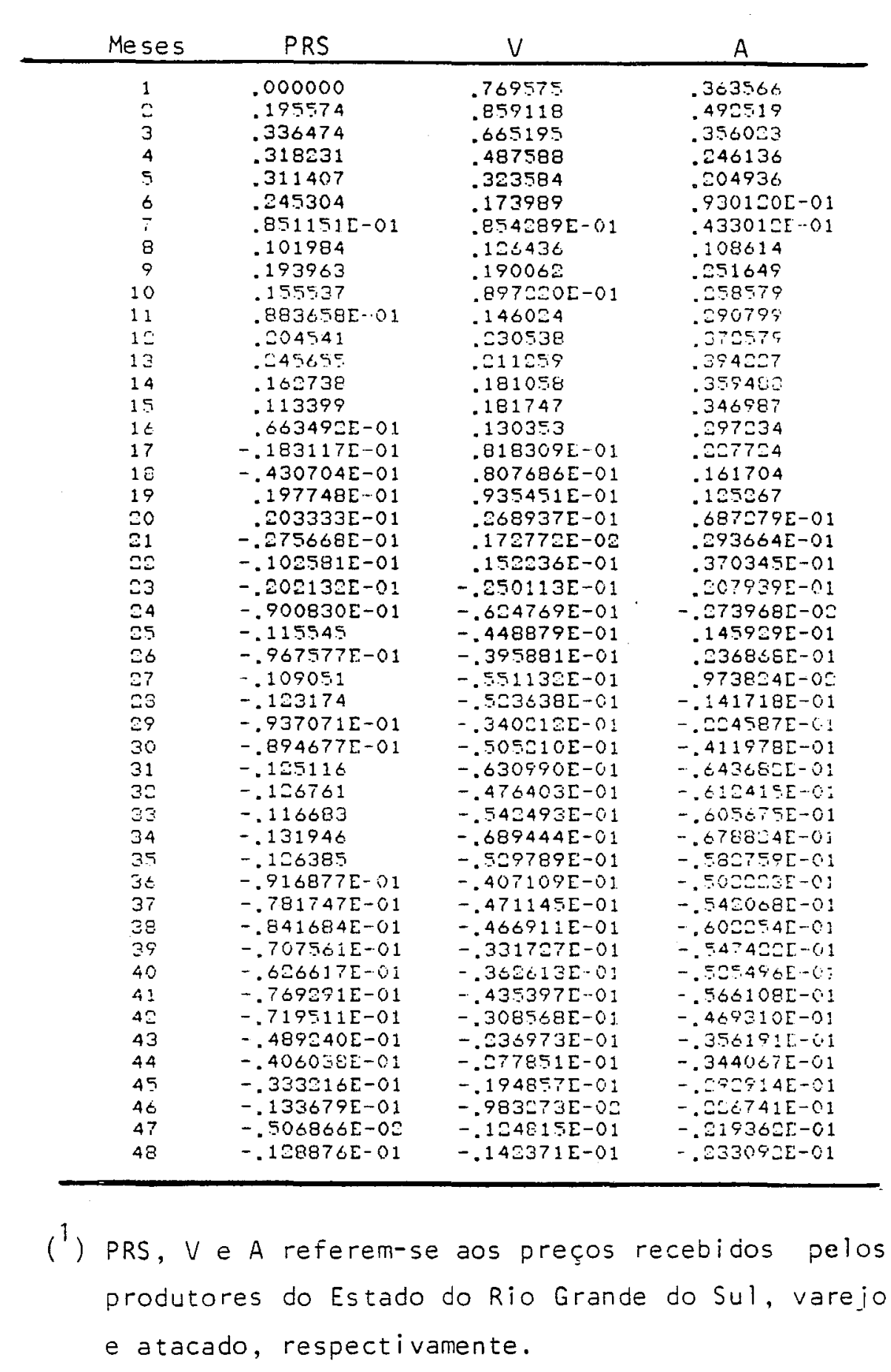


Tabela 53.- Efeitos de um choque de uma unidade de desvio padrão em A sobre o sitema PRS $-V-A(1)$

\begin{tabular}{|c|c|c|c|}
\hline Meses & PRS & V & A \\
\hline 1 & .000000 & .000000 & .695460 \\
\hline$\Sigma$ & .133559 & $-.515855 E-01$ & .609099 \\
\hline 3 & .141065 & $-.656589 E-01$ & .451719 \\
\hline 4 & $-.199509 E-01$ & $-.355925 \mathrm{~L}-05$ & .355804 \\
\hline 5 & $.954082 E-02$ & .121731 & .265034 \\
\hline 6 & .115434 & .228530 & .189677 \\
\hline 7 & .111650 & .145843 & $.200559 E-01$ \\
\hline 8 & -.101895 & $-.719951 \mathrm{C}-01$ & -.1950 .53 \\
\hline 9 & $-.858427 E-01$ & $-.7385 \Omega 0 E-01$ & -.155781 \\
\hline 10 & $-.9050335-01$ & -.158011 & -.175996 \\
\hline 11 & $.1719365-0]$ & $-.746147 E-01$ & $-.74^{5}, 46.4[-0]$ \\
\hline $1 \Sigma$ & $.470729 E-01$ & -.100777 & $-.5907005-01$ \\
\hline$i 3$ & $.591915 E-01$ & -.140920 & $-.811476 E-01$ \\
\hline 14 & $.655: 10 \mathrm{E}-05$ & -.115448 & $-.5245=5[-01$ \\
\hline 15 & $-.428806 E-0 I$ & $-.855850 E-01$ & $-.535 E t 1 E-0:$ \\
\hline 16 & $-.487787 E-01$ & $-.589108 \mathrm{~L}-01$ & $-.880437[-01$ \\
\hline 17 & $-.809583 E-01$ & $-.775942 \mathrm{E}-01$ & -.101605 \\
\hline 18 & -.127377 & $-.950735 \mathrm{C}-01$ & $-.1=3600$ \\
\hline 19 & $-.754796 \mathrm{E}-01$ & $-.395357 E-01$ & $-.413814 \mathrm{E}-01$ \\
\hline$\equiv 0$ & $-.468316 E-01$ & - .597521E-01 & $-.645214 E-01$ \\
\hline$\therefore 1$ & $-.2453 .59 \mathrm{E}-01$ & $-.448535 \mathrm{E}-01$ & $-.686358 \mathrm{E}-01$ \\
\hline 20 & $-.167799 \mathrm{E}-01$ & $-.345808 E-01$ & $-.705591 \mathrm{E}-01$ \\
\hline$=3$ & $-.166737 \mathrm{E}-0 \mathrm{E}$ & $-.575256 \mathrm{E}-01$ & $-.638831 \mathrm{E}-01$ \\
\hline 54 & $-.280215 E-01$ & - .26:321 $\mathrm{E}-01$ & $-.6067665-01$ \\
\hline 25 & $-.542068 E-01$ & $-.261284 \mathrm{E}-01$ & $-.675060 E-01$ \\
\hline 26 & $-.552932 E-01$ & $-.246995 \mathrm{E}-01$ & $-.687905[-01$ \\
\hline 27 & $-.368994 E-01$ & $-.194383 \mathrm{E}-01$ & $-.4884525-01$ \\
\hline 58 & $-.343107 \mathrm{E}-01$ & $-.245967 \mathrm{E}-01$ & $-.51301 \mathrm{CL}-01$ \\
\hline 59 & $.575867 \mathrm{E}-03$ & $.684521 \mathrm{E}-02$ & $-.20436=01$ \\
\hline 30 & $.242572 E-01$ & $-.518086 E-0 \Omega$ & $-.23835=2-01$ \\
\hline 31 & $.2 \approx 61=1 \mathrm{E}-01$ & $-.460054 \mathrm{E}-0 \mathrm{E}$ & $-.201441 E-0 j$ \\
\hline 35 & $.158177 E-01$ & $.361259 \mathrm{E}-02$ & $-.10760=5-01$ \\
\hline 35 & $.135605 E-01$ & $.77: 2005-05$ & $-.566864 E-02$ \\
\hline 34 & $.344119 E-0 E$ & $.510429 E-02$ & -.こラこ6545-:こ \\
\hline 35 & $-.506679 E-0 D$ & $.757835 E-0=$ & $.4 E 4100 E-0 E$ \\
\hline 36 & $.112568 E-01$ & $.150764 \mathrm{E}-01$ & $.968930 \mathrm{~L}-0 \mathrm{I}$ \\
\hline 37 & $.319130 E-01$ & $.207204 E-01$ & $.195887 E-01$ \\
\hline 38 & $.316 .541 E-01$ & $.1271865-01$ & $.947399 E-05$ \\
\hline 39 & $.392699 \mathrm{E}-01$ & $. \simeq 1374.5 \mathrm{E}-01$ & $.145608 E-01$ \\
\hline 40 & $.396696 \mathrm{E}-01$ & $.169695 E-01$ & $.124114 E-01$ \\
\hline 41 & $.996718 \mathrm{E}-01$ & $.112948[-01$ & $.112394[-01$ \\
\hline $4=$ & $.178199 \mathrm{E}-01$ & $.117986 \mathrm{E}-01$ & $.130571 E-01$ \\
\hline 43 & $.192495 \mathrm{E}-01$ & $.134058 E-01$ & $.166555 E-01$ \\
\hline 44 & $.204104 E-01$ & $.1074: 55-01$ & $.17139=E-01$ \\
\hline 4.5 & $.51475 S E-01$ & $.113515 E-01$ & $.1822335-01$ \\
\hline 46 & $.270741 \mathrm{E}-01$ & $.137490 \mathrm{E}-01$ & $.170843 E-01$ \\
\hline 47 & $.336004 E-01$ & $.147630 \mathrm{E}-0 \mathrm{~J}$ & $.182816 E-01$ \\
\hline 48 & $.55 こ 398 E-01$ & $.752438 \mathrm{E}-02$ & $.109594[-01$ \\
\hline
\end{tabular}

(') PRS, V e A referem-se aos preços recebidos pelos produtores do Estado do Rio Grande do Sul, varejo e atacado, respectivamente. 
Tabela 54.- Decomposição da variāncia dos erros de previsão (48 períodos). ordenação: PMT, $V, A\left(^{1}\right)$

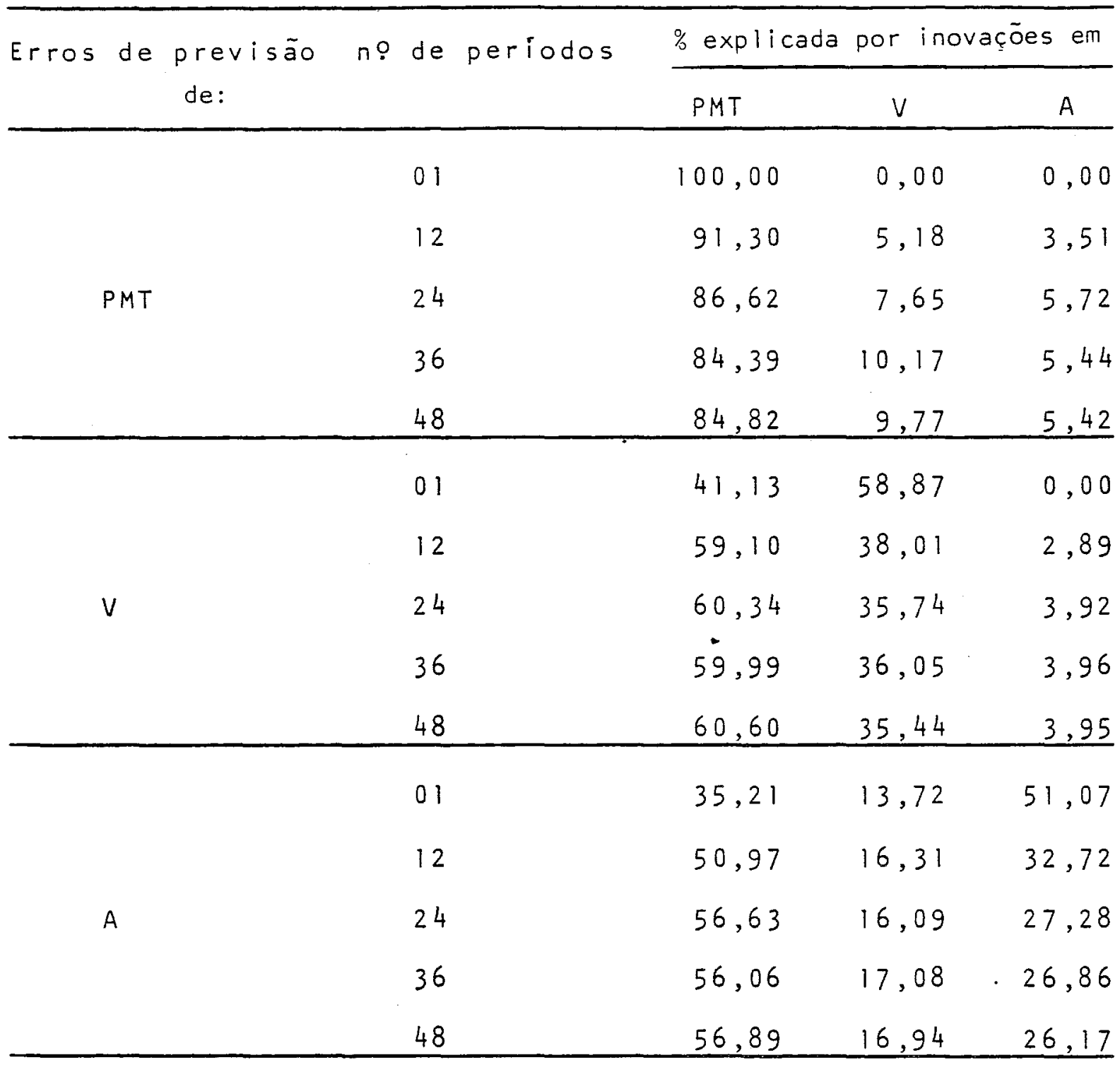

( ${ }^{1}$ ) PMT, $V$ e A referem-se aos preços recebidos pelos produtores de Mato Grosso e pelos mercados varejista e atacadista da cidade de São Paulo, respectivamente. 
Tabela 55.- Decomposição da variância dos erros de previsão (48 períodos). ordenaçäo: $A, V, \operatorname{PMT}\left({ }^{1}\right)$

\begin{tabular}{|c|c|c|c|c|}
\hline \multirow{2}{*}{$\begin{array}{c}\text { Erro de previsão } \\
\text { de: }\end{array}$} & \multirow{2}{*}{ no de períodos } & \multicolumn{3}{|c|}{ \% explicada por inovações em } \\
\hline & & A & v & PMT \\
\hline \multirow{5}{*}{ A } & 01 & 100,00 & 0,00 & 0,00 \\
\hline & 12 & 80,34 & 10,98 & 8,69 \\
\hline & 24 & 66,78 & 17,39 & 15,83 \\
\hline & 36 & 66,18 & 17,61 & 16,20 \\
\hline & 48 & 65,35 & 18,11 & 16,53 \\
\hline \multirow{5}{*}{ V } & 01 & 44,19 & 55,81 & 0,00 \\
\hline & 12 & 42,88 & 45,21 & 11,90 \\
\hline & 24 & 40,31 & 43,95 & 15,81 \\
\hline & 36 & 40,56 & 43,78 & 15,68 \\
\hline & 48 & 40,30 & 43,55 & 16,14 \\
\hline \multirow{5}{*}{ PMT } & 01 & 35,21 & 10,92 & 53,87 \\
\hline & 12 & 40,53 & 15,45 & 44,01 \\
\hline & 24 & 35,03 & 15,16 & 49,81 \\
\hline & 36 & 36,44 & 17,22 & 46,34 \\
\hline & 48 & 35,55 & 17,95 & 46,50 \\
\hline
\end{tabular}

(1) A, V e PMT referem-se aos preços recebidos pelos mercados atacadista e varejista da cidade de são paulo e pelos produtores de Mato Grosso, respectivamente. 
Tabela 56. - Decomposição da variancia dos erros de previsão (48 períodos). ordenação: $P G O, V, A\left(^{1}\right)$.

\begin{tabular}{|c|c|c|c|c|}
\hline \multirow{2}{*}{$\begin{array}{c}\text { Erro de previsão } \\
\text { de: }\end{array}$} & \multirow{2}{*}{ no de períodos. } & \multicolumn{3}{|c|}{$\%$ explicada por inovações em } \\
\hline & & PGO & V & A \\
\hline \multirow[t]{5}{*}{ PGO } & 01 & 100,00 & 0,00 & 0,00 \\
\hline & 12 & 92,32 & 4,56 & 3,11 \\
\hline & 24 & 86,11 & 5,75 & 8,14 \\
\hline & 36 & 85,26 & 7,17 & 7,57 \\
\hline & 48 & 85,40 & 6,91 & 7,68 \\
\hline \multirow[t]{5}{*}{ V } & 01 & 48,00 & 52,00 & 0,00 \\
\hline & 12 & 68,55 & 29,02 & 2,42 \\
\hline & 24 & 67,46 & 27,92 & 4,62 \\
\hline & 36 & 67,43 & 27,94 & 4,63 \\
\hline & 48 & 67,95 & 27,36 & 4,69 \\
\hline \multirow[t]{5}{*}{ A } & 01 & 37,75 & 10,11 & 52,13 \\
\hline & 12 & 63,30 & 8,88 & 27,81 \\
\hline & 24 & 65,84 & 10,35 & 23,81 \\
\hline & 36 & 65,48 & 11,05 & 23,47 \\
\hline & 48 & 66,33 & 10,89 & 22,78 \\
\hline
\end{tabular}

(') PGO, V e A referem-se aos preços recebidos pelos produtores de Goiàs e mercados varejista e atacadista da cidade de São Paulo, respectivamente. 
Tabela 57. - Decomposição da variância dos erros de previsão (48 períodos). ordenação: $A, V, P G O\left({ }^{1}\right)$

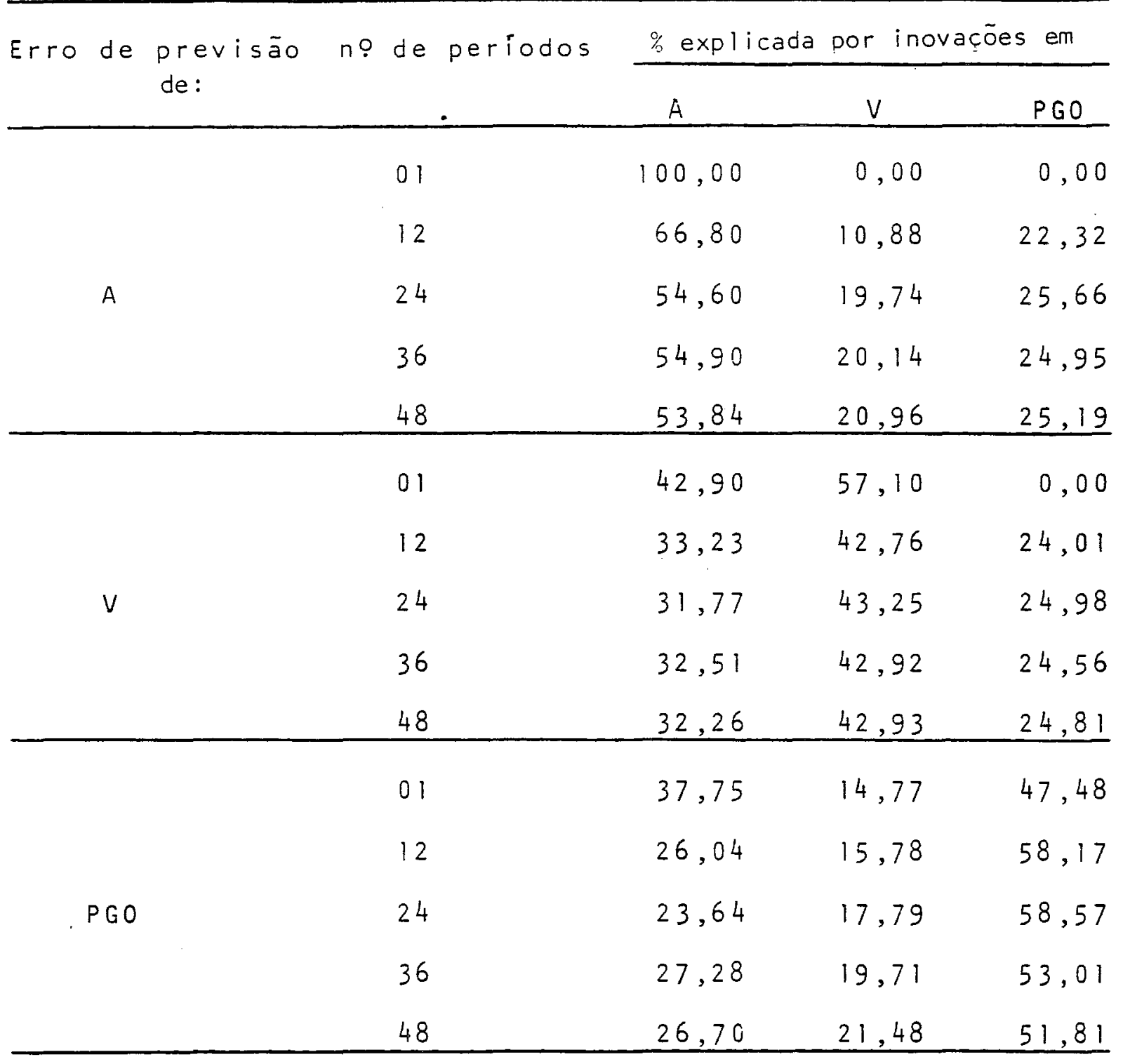

(') A, V, PGO referem-se aos preços recebidos pelos mercados atacadista e varejista da cidade de são paulo e pelos produtores de Goiàs, respectivamente. 
Tabela 58. - Decomposição da variância dos erros de previsão (48 períodos). Ordenação: PMG, $V, A\left(^{1}\right)$

\begin{tabular}{|c|c|c|c|c|}
\hline \multirow{2}{*}{$\begin{array}{c}\text { Erro de previsão } \\
\text { de: }\end{array}$} & \multirow{2}{*}{ no de períodos } & \multicolumn{3}{|c|}{ \% explicada por inovaçōes em } \\
\hline & & PMG & v & A \\
\hline \multirow{5}{*}{ PMG } & 01 & 100,00 & 0,00 & 0,00 \\
\hline & 12 & 83,07 & 9,98 & 6,95 \\
\hline & 24 & 72,50 & 13,30 & 14,20 \\
\hline & 36 & 70,45 & 15,81 & 13,72 \\
\hline & 48 & 70,29 & 16,03 & 13,68 \\
\hline \multirow{5}{*}{ v } & 01 & 39,64 & 60,36 & 0,00 \\
\hline & 12 & 56,54 & 38,79 & 4,67 \\
\hline & 24 & 53,02 & 38,08 & 8,89 \\
\hline & 36 & 52,05 & 39,03 & 8,92 \\
\hline & 48 & 51,98 & 39,14 & 8,88 \\
\hline \multirow{5}{*}{ A } & 01 & 31,21 & 15,79 & 53,00 \\
\hline & 12 & 50,91 & 15,43 & 33,65 \\
\hline & 24 & 49,86 & 18,77 & 31,37 \\
\hline & 36 & 48,63 & 20,13 & 31,24 \\
\hline & 48 & 48,46 & 20,60 & 30,84 \\
\hline
\end{tabular}


Tabela 59. - Decomposição da variância dos erros de previsão (48 períodos). Ordenação: A, V, PMG $\left(^{1}\right)$

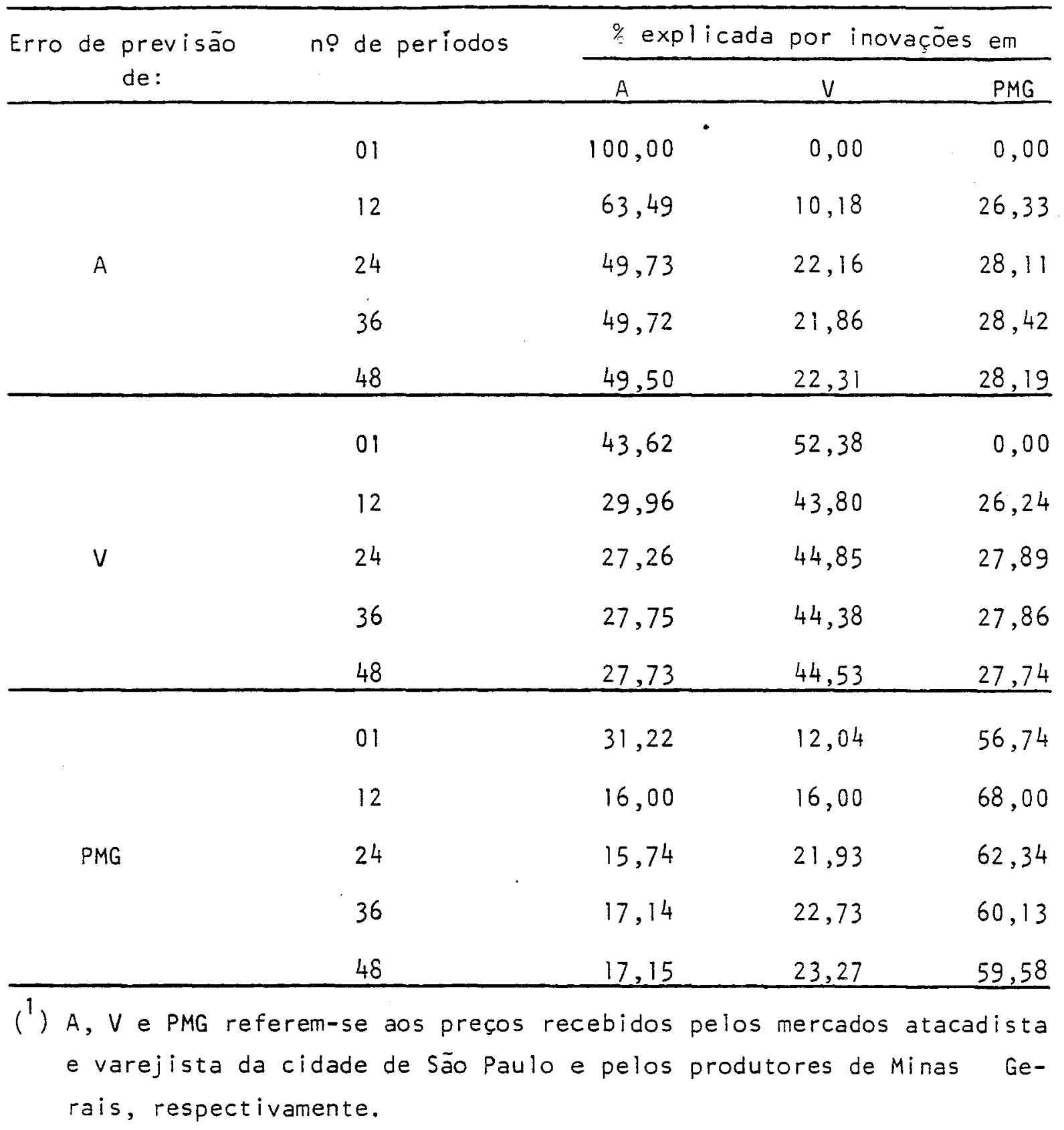


Tabela 60.- Decomposição da variância dos erros de previsão (48 períodos). Ordenação: PRS, $V, A\left({ }^{1}\right)$

\begin{tabular}{|c|c|c|c|c|}
\hline \multirow{2}{*}{$\begin{array}{c}\text { Erro de previsão } \\
\text { de: }\end{array}$} & \multirow{2}{*}{ no de períodos } & \multicolumn{3}{|c|}{ \% explicada por inovações em } \\
\hline & & PRS & v & A \\
\hline \multirow{5}{*}{ PRS } & 01 & 100,00 & 0,00 & 0,00 \\
\hline & 12 & 94,99 & 4,28 & 0,73 \\
\hline & 24 & 94,51 & 4,56 & 0,92 \\
\hline & 36 & 93,56 & 5,48 & 0,96 \\
\hline & 48 & 93,31 & 5,67 & 1,01 \\
\hline \multirow{5}{*}{$v$} & 01 & 40,78 & 59,22 & 0,00 \\
\hline & 12 & 58,18 & 39,30 & 2,52 \\
\hline & 24 & 57,71 & 38,87 & 3,40 \\
\hline & 36 & 57,45 & 39,11 & 3,42 \\
\hline & 48 & 57,37 & 39,17 & 3,46 \\
\hline \multirow[t]{2}{*}{. } & 01 & 38,42 & 13,21 & 48,37 \\
\hline & 12 & 59,48 & 16,72 & 23,81 \\
\hline \multirow[t]{3}{*}{ A } & 24 & 59,16 & 21,15 & 19,68 \\
\hline & 36 & 58,89 & 21,34 & 19,76 \\
\hline & 48 & 58,74 & 21,55 & 19,70 \\
\hline
\end{tabular}

(1) PRS, V e A referem-se aos preços recebidos pelos produtores de São Paulo e mercados varejista e atacadista da cidade de São Paulo, respectivamente. 
Tabela 61.- Decomposição da variância dos erros de previsão (48 períodos). Ordenação: $A, V, \operatorname{PRS}\left({ }^{1}\right)$

\begin{tabular}{|c|c|c|c|c|}
\hline \multirow{2}{*}{$\begin{array}{c}\text { Erro de previsão } \\
\text { de: }\end{array}$} & \multirow[t]{2}{*}{ no de períodos } & \multicolumn{3}{|c|}{$\%$ explicada por inovaçōes em } \\
\hline & & A & V & PRS \\
\hline \multirow{5}{*}{ A } & 01 & 100,00 & 0,00 & 0,00 \\
\hline & 12 & 77,96 & 13,90 & 8,14 \\
\hline & 24 & 68,66 & 23,43 & 7,90 \\
\hline & 36 & 68,45 & 23,63 & 7,92 \\
\hline & 48 & 68,22 & 23,89 & 7,88 \\
\hline \multirow{5}{*}{ V } & 01 & 45,64 & 54,36 & 0,00 \\
\hline & 12 & 48,66 & 45,52 & 5,81 \\
\hline & 24 & 46,34 & 47,40 & 6,25 \\
\hline & 36 & 46,29 & 47,42 & 6,29 \\
\hline & 48 & 46,19 & 47,53 & 6,27 \\
\hline \multirow{5}{*}{ PRS } & 01 & 38,42 & 8,89 & 52,69 \\
\hline & 12 & 48,45 & 17,04 & 34,50 \\
\hline & 24 & 47,55 & 17,64 & 34,81 \\
\hline & 36 & $47,60^{\circ}$ & 18,33 & 34,06 \\
\hline & 48 & 47,38 & 18,74 & 33,88 \\
\hline
\end{tabular}


APENDICE 3 
Tabela 62. - Parcelas absolutas de comercialização de carne bovina, em Cz\$/kg. Médias anuais $(1971 / 87)\left({ }^{1}\right)$

\begin{tabular}{|c|c|c|c|}
\hline Ano & $\begin{array}{c}\text { Parcela } \\
\text { Total }\end{array}$ & $\begin{array}{c}\text { Parcela do } \\
\text { Varejo }\end{array}$ & $\begin{array}{l}\text { Parcela do } \\
\text { Atacado }\end{array}$ \\
\hline 1971 & 64,49 & 53,31 & 11,18 \\
\hline 1972 & 59,14 & 57,42 & 1,72 \\
\hline 1973 & 66,88 & 94,68 & $-19,14$ \\
\hline 1974 & 59,00 & 64,31 & 0,43 \\
\hline 1975 & 84,54 & 68,68 & 15,87 \\
\hline 1976 & 71,85 & 55,94 & 15,90 \\
\hline 1977 & 55,00 & 60,04 & 2,63 \\
\hline 1978 & 79,45 & 84,32 & $-4,86$ \\
\hline 1979 & 75,56 & 71,18 & 11,24 \\
\hline 1980 & 85,57 & 70,40 & 15,17 \\
\hline 1981 & 77,92 & 55.07 & 22,86 \\
\hline 1982 & 81,83 & 57,76 & 24,10 \\
\hline 1983 & 86,54 & 72,66 & 20,16 \\
\hline 1984 & 70,69 & 60,41 & 10,27 \\
\hline 1985 & 66,14 & 49,67 & 16,47 \\
\hline 1986 & 61,17 & 45,46 & 19,45 \\
\hline 1987 & 78,06 & 55,86 & 22,19 \\
\hline
\end{tabular}

(') Preços produtor do Estado de São Paulo e mercados atacadista e varejista da cidade de São Paulo. 
Tabela 63. - Parcelas absolutas de comercialização de carne bovina $\left({ }^{1}\right)$ dos açougues e supermercados da cidade de são Paulo, 1971/87. Mëdias anuais, em $\mathrm{CzS} / \mathrm{kg}$.

\begin{tabular}{|c|c|c|}
\hline Anos & Açougues & Supermercados \\
\hline 1971 & 53,99 & 51,17 \\
\hline 1972 & 58,52 & 53,91 \\
\hline 1973 & 102,53 & 69,78 \\
\hline 1974 & 67,43 & 54,40 \\
\hline 1975 & 72,69 & 53,98 \\
\hline 1976 & 58,93 & 46,45 \\
\hline 1977 & 66,61 & 39,24 \\
\hline 1978 & 96,65 & 45,47 \\
\hline 1979 & 84,83 & 27,98 \\
\hline 1980 & 77,02 & 49,44 \\
\hline 1981 & 60,63 & 37,45 \\
\hline 1982 & 61,73 & 44,45 \\
\hline 1983 & 68,48 & 54,06 \\
\hline 1984 & 61,48 & 55,16 \\
\hline 1985 & 50,91 & 45,50 \\
\hline 1986 & 47,28 & 23,08 \\
\hline 1987 & 58,49 & 47,07 \\
\hline
\end{tabular}


Tabela 64.- Parcelas absolutas de comercialização de carne bovina de segunda, dos acougues e supermercados da cidade de São Paulo, 1971/87. Médias anuais: em $\mathrm{CzS} / \mathrm{kg}$.

\begin{tabular}{|c|c|c|}
\hline Anos & Açougues & Supermercados \\
\hline 1971 & 42,93 & 40,18 \\
\hline 1972 & 41,41 & 40,69 \\
\hline 1973 & 79,35 & 49,20 \\
\hline 1974 & 42,24 & 30,31 \\
\hline 1975 & 50,78 & 31,39 \\
\hline 1976 & 40,66 & 32,12 \\
\hline 1977 & 47,33 & 23,15 \\
\hline 1978 & 74,50 & 26,00 \\
\hline 1979 & 59,42 & 4,30 \\
\hline 1980 & 54,77 & 28,22 \\
\hline 1981 & 42,64 & 25,61 \\
\hline 1982 & 46,29 & 35,10 \\
\hline 1983 & 48,95 & 39,46 \\
\hline 1984 & 42,94 & 41,27 \\
\hline 1985 & 34,58 & 30,81 \\
\hline 1986 & 24,77 & 11,77 \\
\hline 1987 & 34,37 & 34,68 \\
\hline
\end{tabular}


Tabela 65.- Parcelas absolutas de comercializaçäo de carne bovina de primeira dos açougues e supermercados da cidade de são paulo, 1971/87. Médias anuais, em CzS/kg.

\begin{tabular}{|c|c|c|}
\hline Anos & Açougues & Supermercados \\
\hline 1971 & 67,25 & 64,36 \\
\hline 1972 & 74,22 & 68,30 \\
\hline 1973 & 126,07 & 97,98 \\
\hline 1974 & 96,36 & 83,64 \\
\hline 1975 & 98,36 & 83,48 \\
\hline 1976 & 80,25 & 64,52 \\
\hline 1977 & 87,76 & 57,80 \\
\hline 1978 & 120,65 & 67,43 \\
\hline 1979 & 112,93 & 54,65 \\
\hline 1980 & 101,78 & 70,58 \\
\hline 1981 & 75,24 & 57,00 \\
\hline 1982 & 79,17 & 56,94 \\
\hline 1983 & 88,53 & 69,98 \\
\hline 1984 & 80,98 & 73,74 \\
\hline 1985 & 69,76 & 62,94 \\
\hline 1986 & 74,50 & 34,44 \\
\hline 1987 & 85,79 & 71,79 \\
\hline
\end{tabular}


Tabela 66. - Parcelas absolutas de comercialização de bovina, em $C z \$ / \mathrm{kg}$. Médias mensais $(1971 / 87)\left(^{1}\right)$

\begin{tabular}{llcl}
\hline Meses & $\begin{array}{l}\text { Parcela } \\
\text { Total }\end{array}$ & $\begin{array}{c}\text { Parcela do } \\
\text { Varejo }\end{array}$ & $\begin{array}{c}\text { Parcela do } \\
\text { Atacado }\end{array}$ \\
\hline Janeiro & 79,64 & 68,74 & 10,90 \\
Fevereiro & 76,43 & 62,48 & 12,75 \\
Março & 74,54 & 60,02 & 14,15 \\
Abril & 72,62 & 60,05 & 12,58 \\
Maio & 70,60 & 59,32 & 10,78 \\
Junho & 69,49 & 58,47 & 10,15 \\
Julho & 74,83 & 57,44 & 12,86 \\
Agosto & 73,78 & 60,59 & 13,20 \\
Setembro & 72,30 & 61,90 & 10,39 \\
Outubro & 72,06 & 64,39 & 7,67 \\
Novembro & 73,04 & 67,70 & 5,32 \\
Dezembro & 74,96 & 66,77 & \\
\hline
\end{tabular}

(') Preços produtor do Estado de São Paulo e mercados atacadista e varejista da cidade de São paulo. 
Tabela 67.- Parcelas absolutas de comercializaçāo de carne bovina $\left({ }^{1}\right)$ dos açougues e supermercados da cidade de São Paulo, 1971/87. Médias mensais, em $\mathrm{CzS} / \mathrm{kg}$.

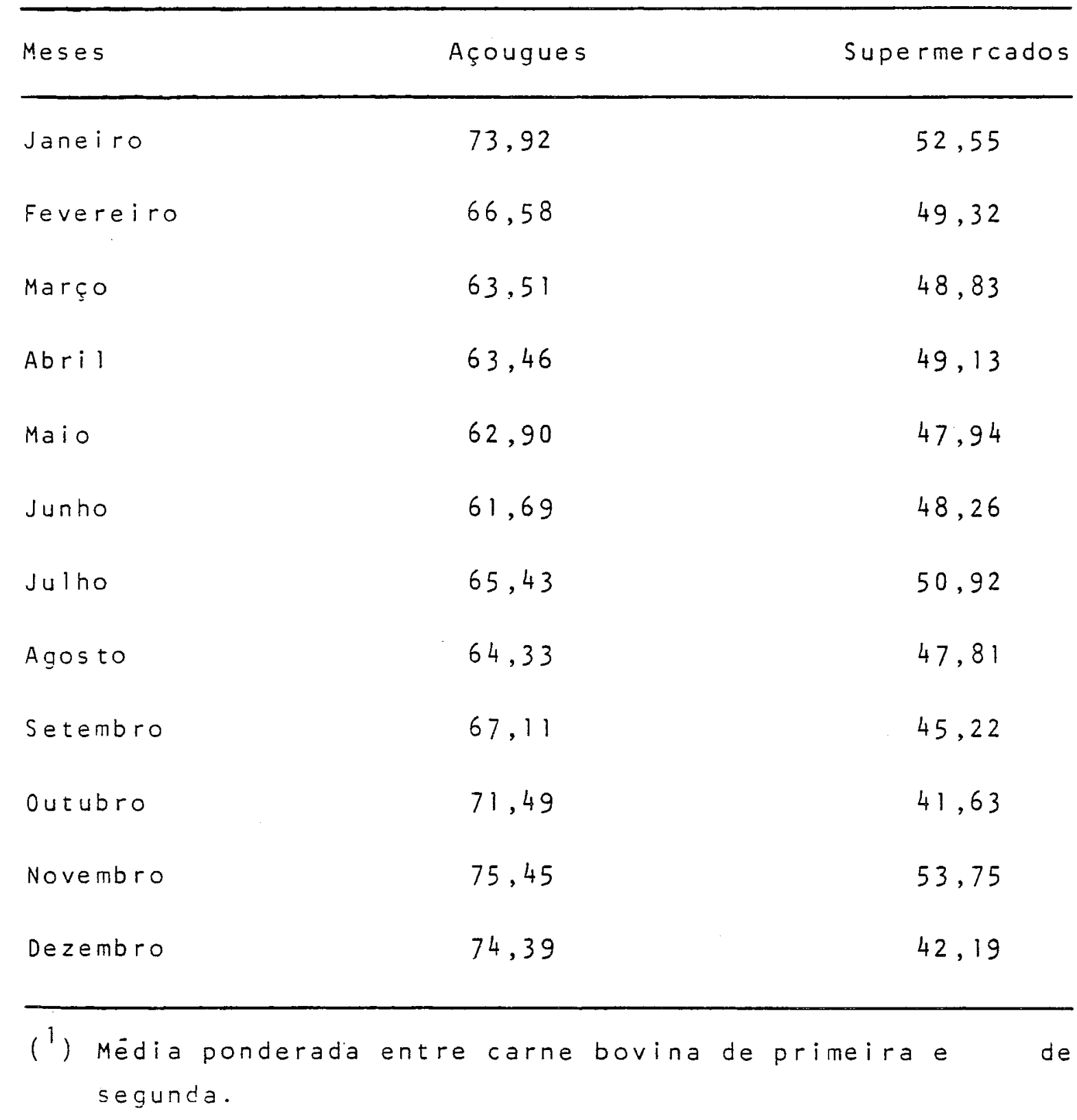


Tabela 68. - Parcelas absolutas de comercialização de carne bovina de segunda dos açougues e supermercados da cidade de são paulo, 1971/87. Médias mensais, em $c z S / k g$.

\begin{tabular}{lcc} 
Meses & Açougues & Supermercados \\
\hline Janeiro & 51,53 & 35,51 \\
Fevereiro & 48,65 & 35,17 \\
Março & 44,60 & 32,60 \\
Abril & 43,77 & 33,18 \\
Maio & 45,40 & 32,13 \\
Junho & 43,25 & 31,04 \\
Julho & 44,09 & 32,01 \\
Agosto & 45,80 & 41,77 \\
Setembro & 45,49 & 27,25 \\
Outubro & 49,44 & 28,04 \\
Novembro & 45,19
\end{tabular}


Tabela 69.- Parcelas absolutas de comercialização de carne bovina de primeira dos açougues e supermercados da cidade de são Paulo, 1971/87. Médias mensais. em $\mathrm{C} z \$ / \mathrm{kg}$.

\begin{tabular}{lcc}
\hline Meses & Açougues & Supermercados \\
\hline Janeiro & 97,60 & 75,88 \\
Fevereiro & 87,64 & 70,38 \\
Março & 84,68 & 67,78 \\
Abril & 83,56 & 67,83 \\
Maio & 82,74 & 66,40 \\
Junho & 81,36 & 66,64 \\
Julho & 85,69 & 71,37 \\
Agosto & 85,44 & 68,21 \\
Setembro & 89,78 & 65,51 \\
Outubro & 97,45 & 66,12 \\
Novembro & 100,75 & 60,63
\end{tabular}




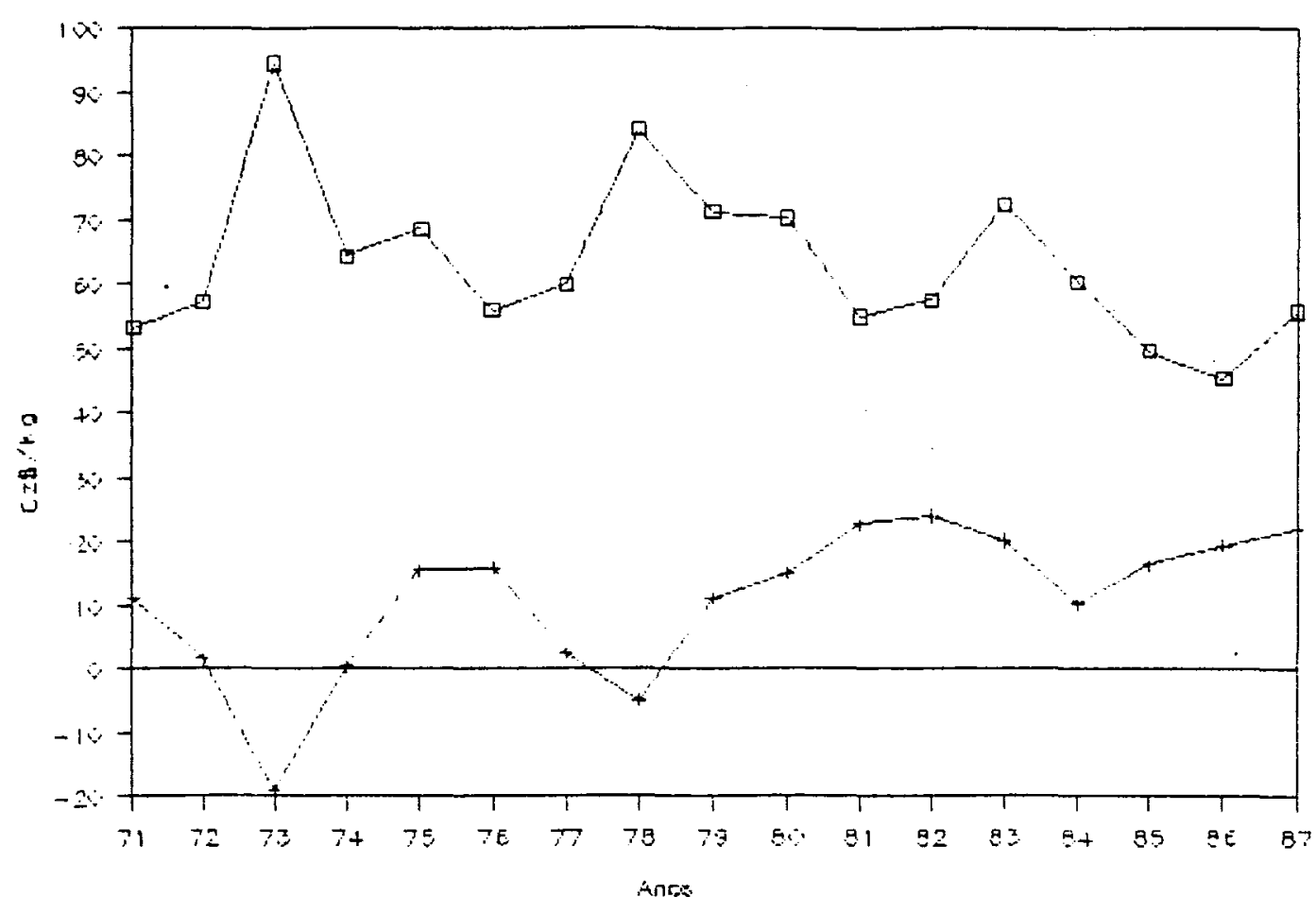

口 roreio Anse +0.06000

Figura 35. Parcelas absolutas de comercialização de carne bovina, em $C z \$ / k g$. Medias anuais, $1971 / 87$.

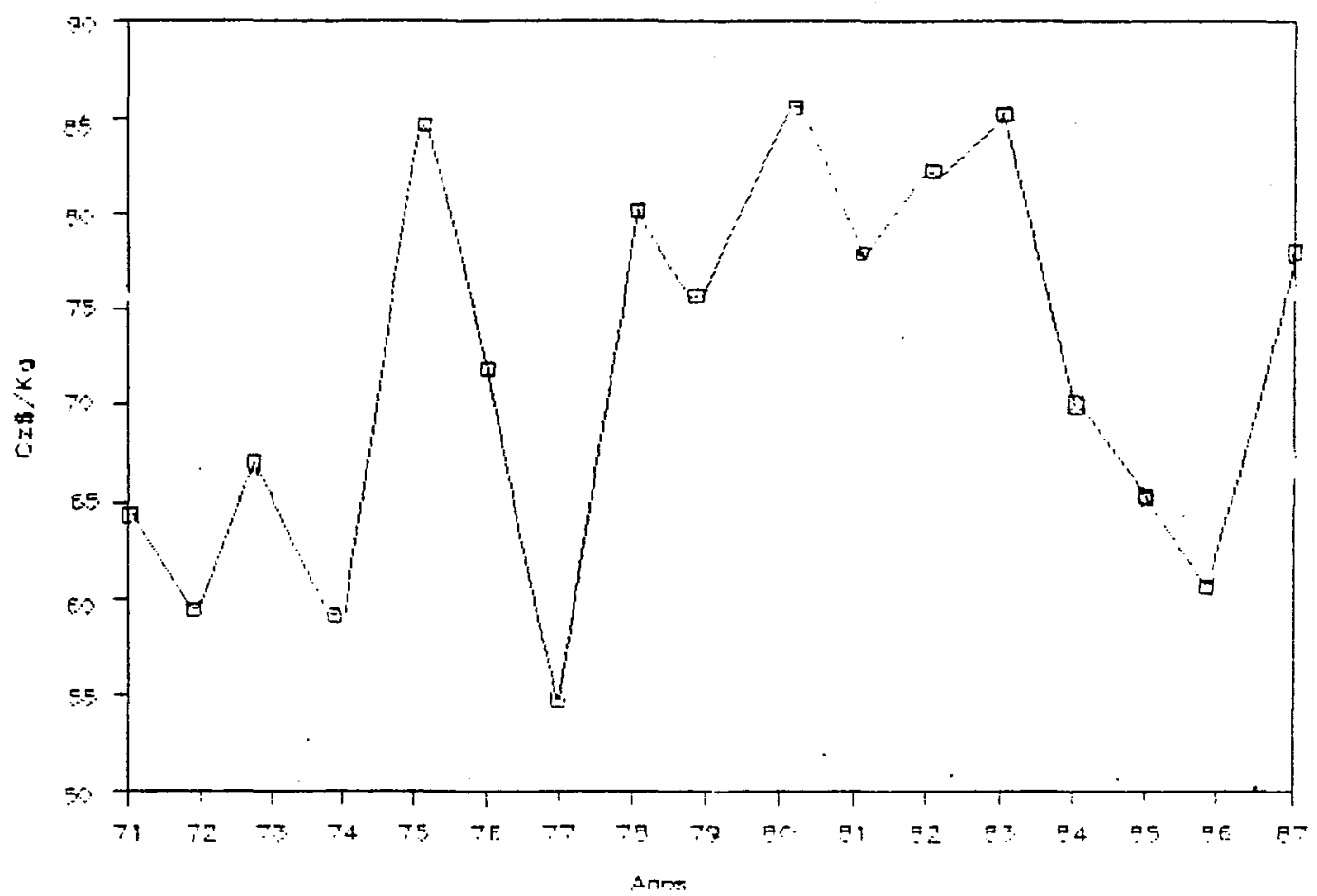

Figura 36. - Farcela absoluta total de comercializaça de carne bovina, em Czs/ko.Médias anuais. 1971/87. 


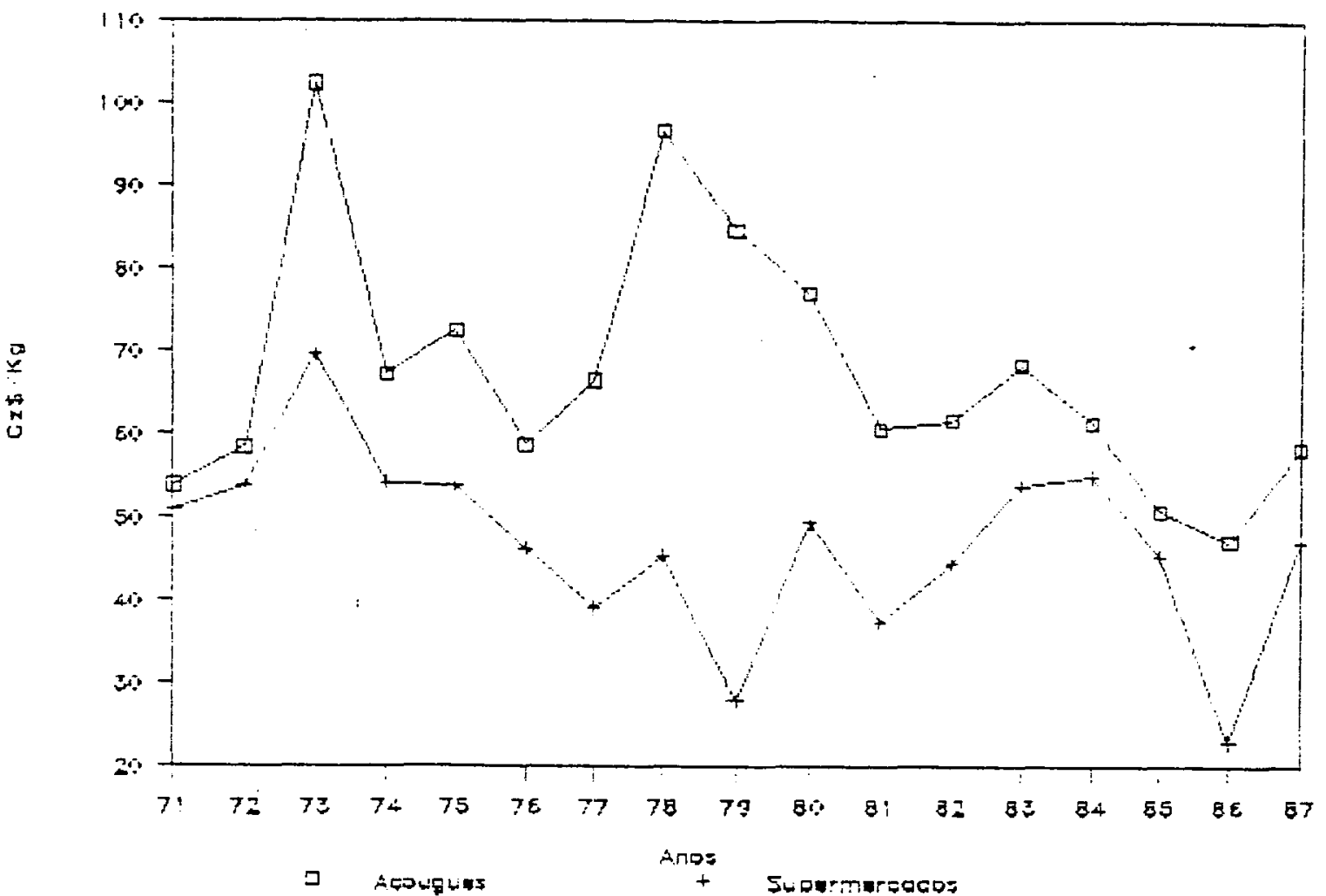

Figura 37. - Parcelas absoiutas de comercializacảo de carne bovina. (Méoia ponderaca entre carne de primeira e de seçundaldos acoucues e suoer nercacos a cidade je säo faulo, en tz\$/kg.Mejcias ancis $1971 / 87$.

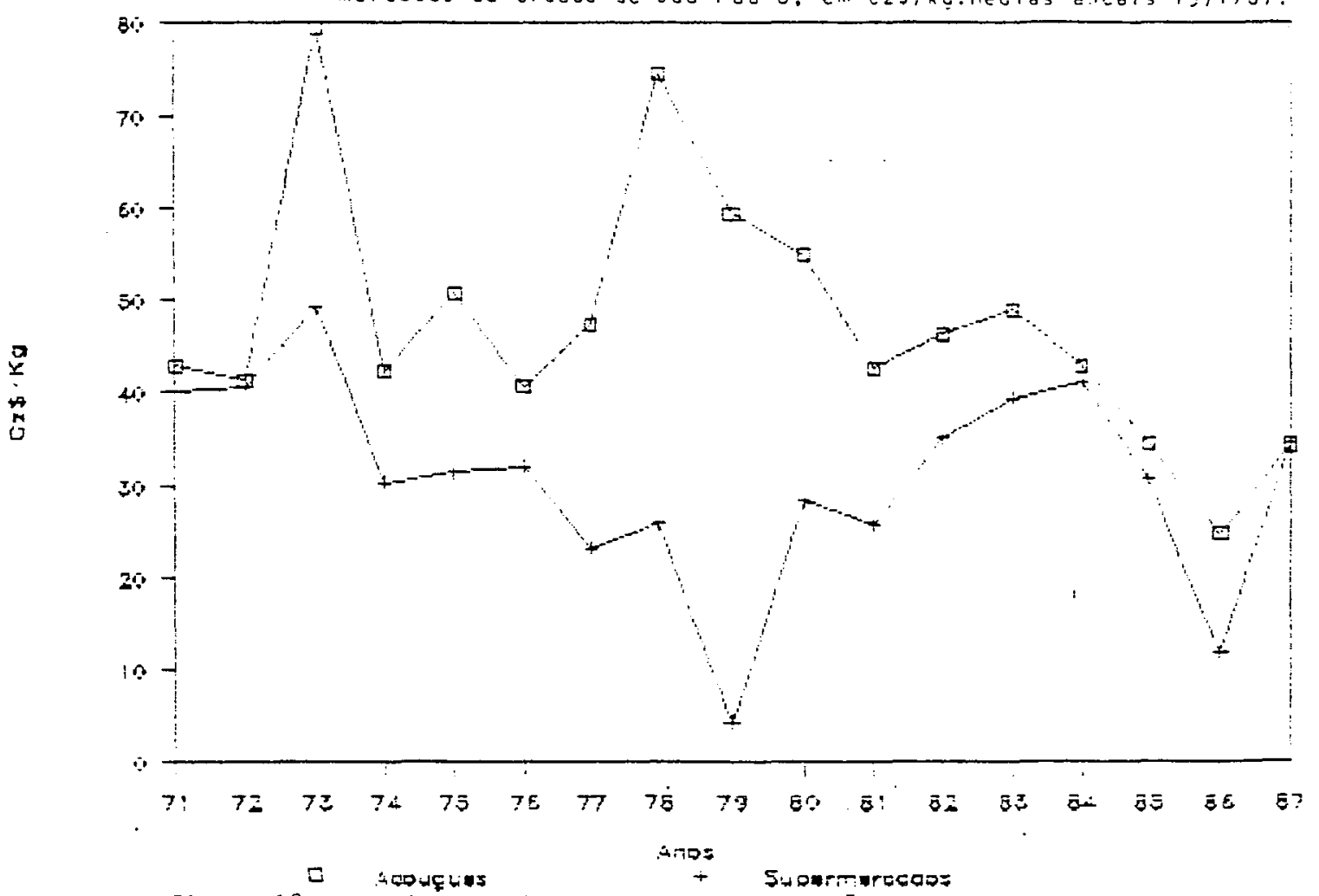

Figura 38. Parcelas absolutas de comercieiizacio de arne ocvina de segunoa ccs açougues e sudermercosos da cioage de sióo pulo, er izsikg . Mejuias anuais, $1971 / 87$. 


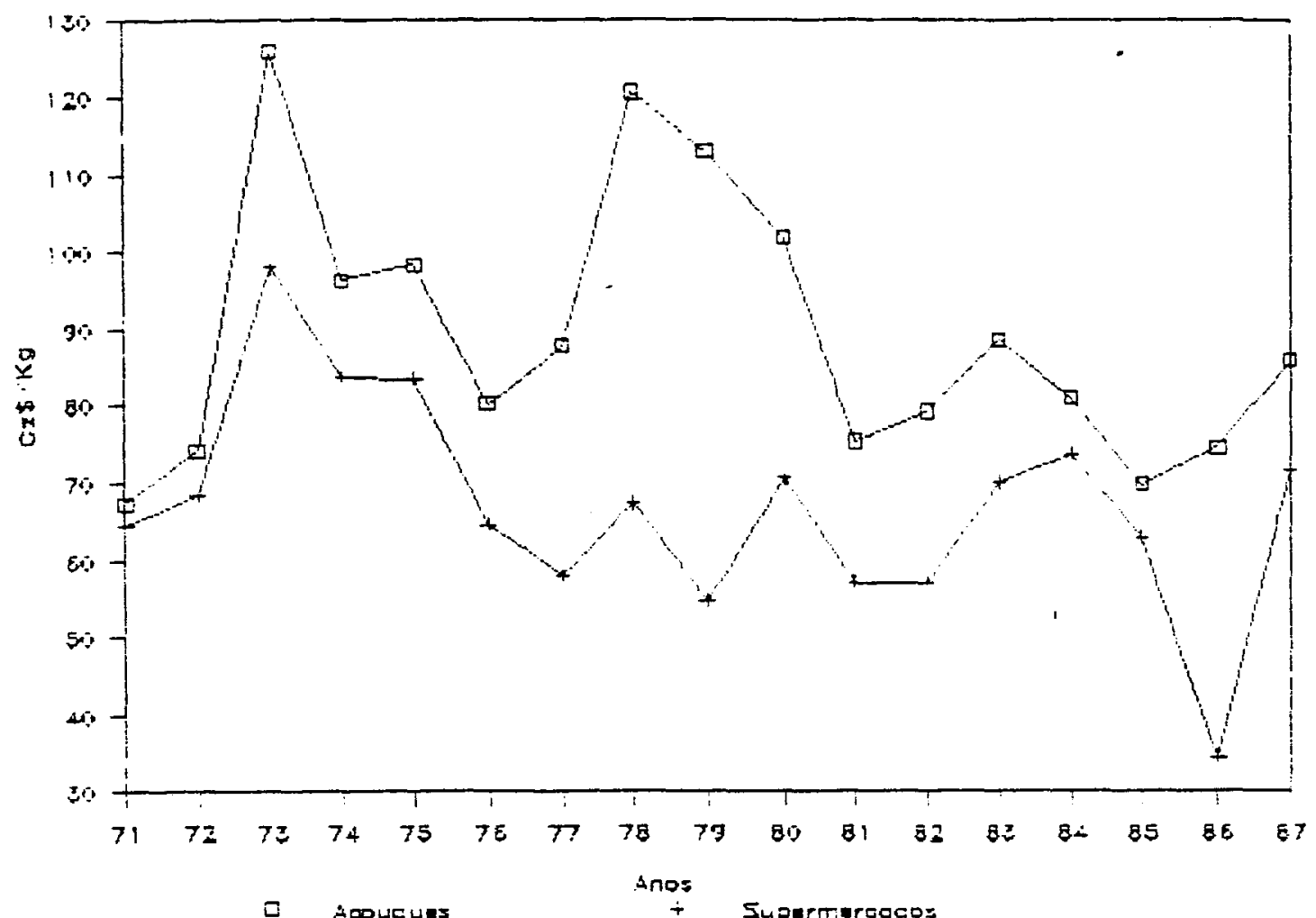

Figura 39. Parcelas absolutas de comercializaça ae carne dovina je orimeira dos açougues e supermercados da cidade de săo Paulo, en Czs/kg. Mécias anuais, $1971 / 87$.

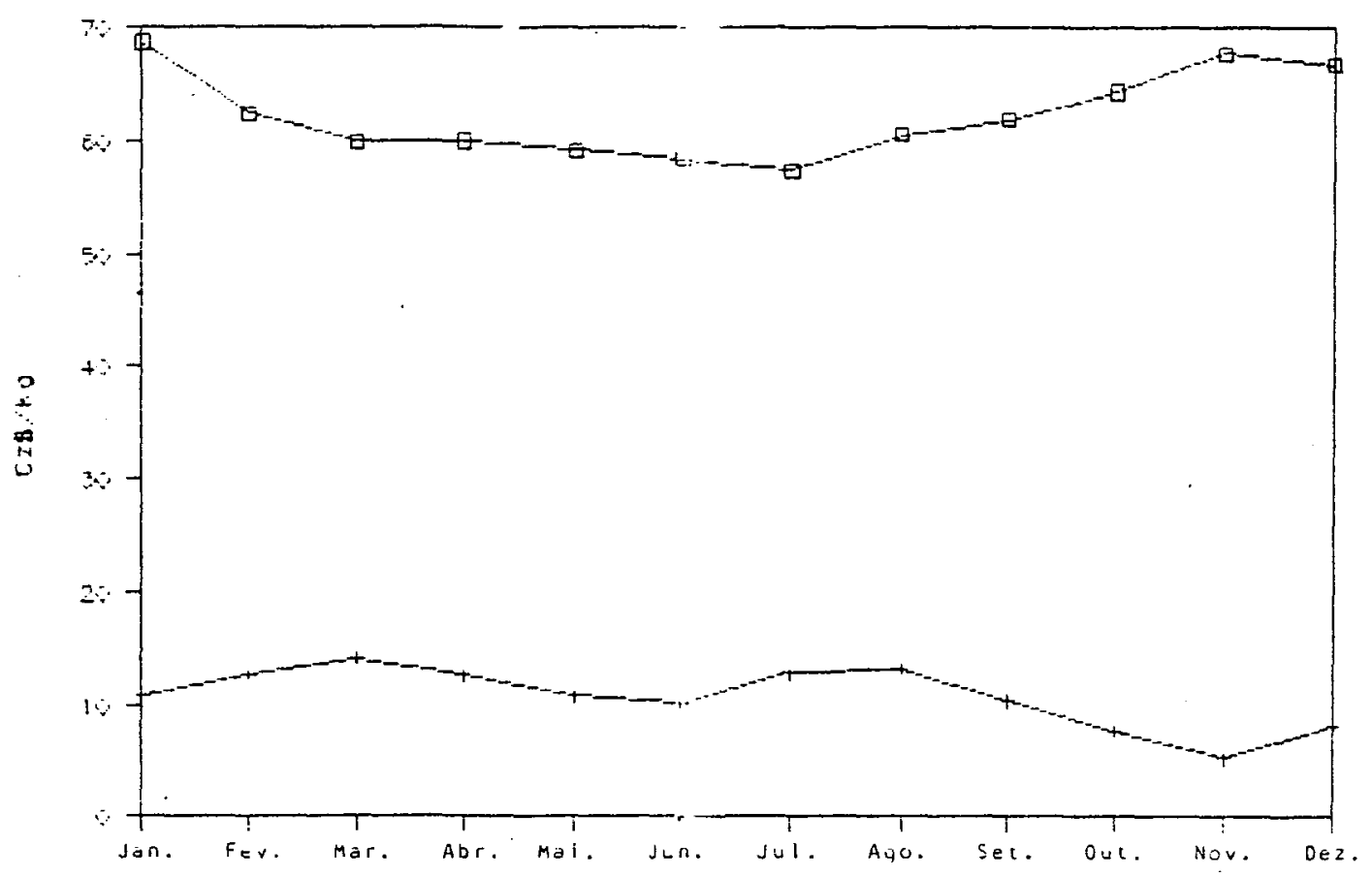

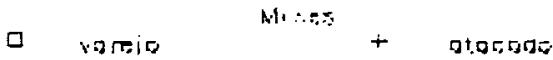

Figura 40 - Parcelas absolutas de comereializaçāo de carne bovina, em Cz\$lkg. Médias mensais, $1971 / 87$. 


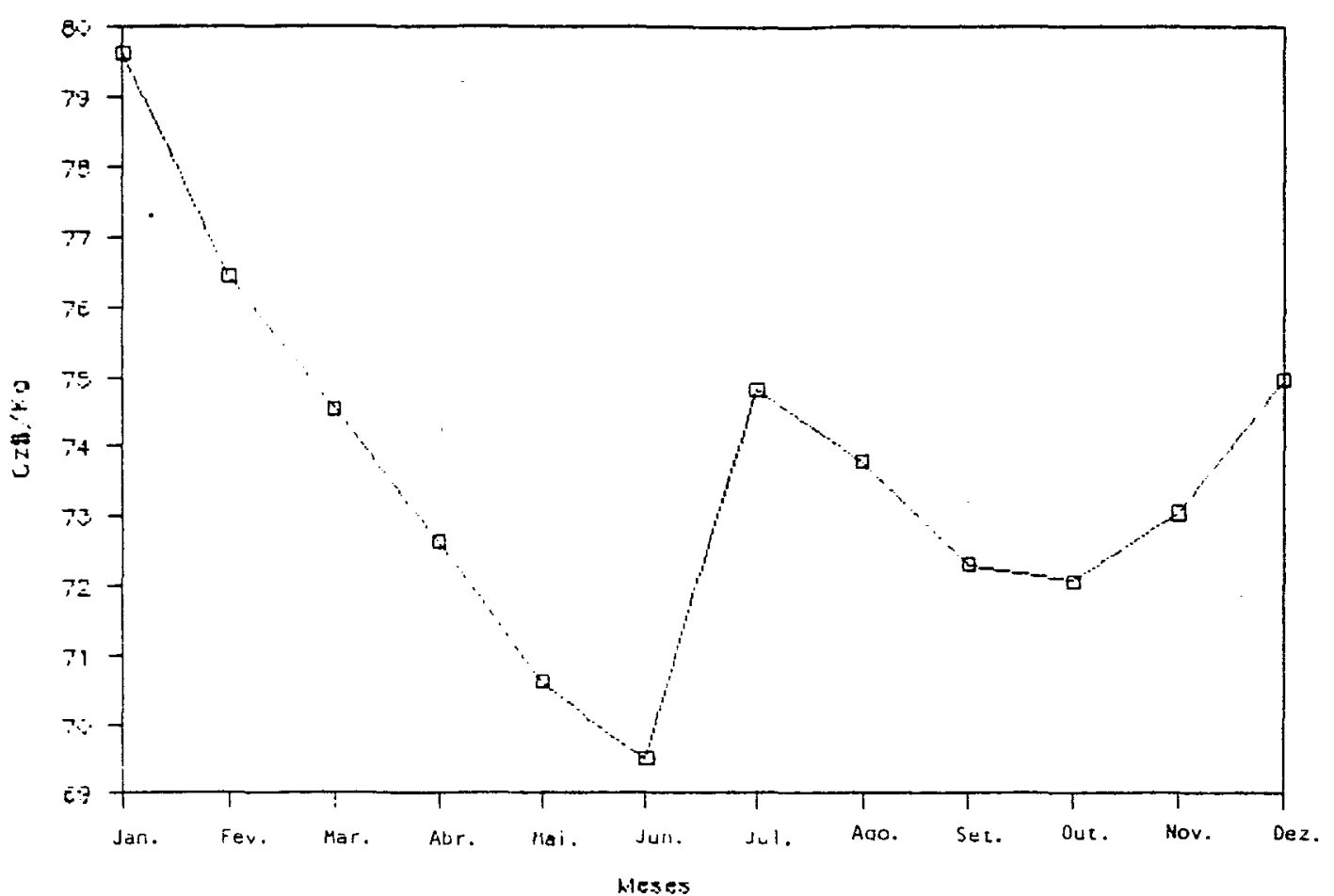

figura 4 l. - Parcela absoluta total de comercializaçäo de carne bovina. En. Czs/kg. Méoias mensais, $1971 / 87$.

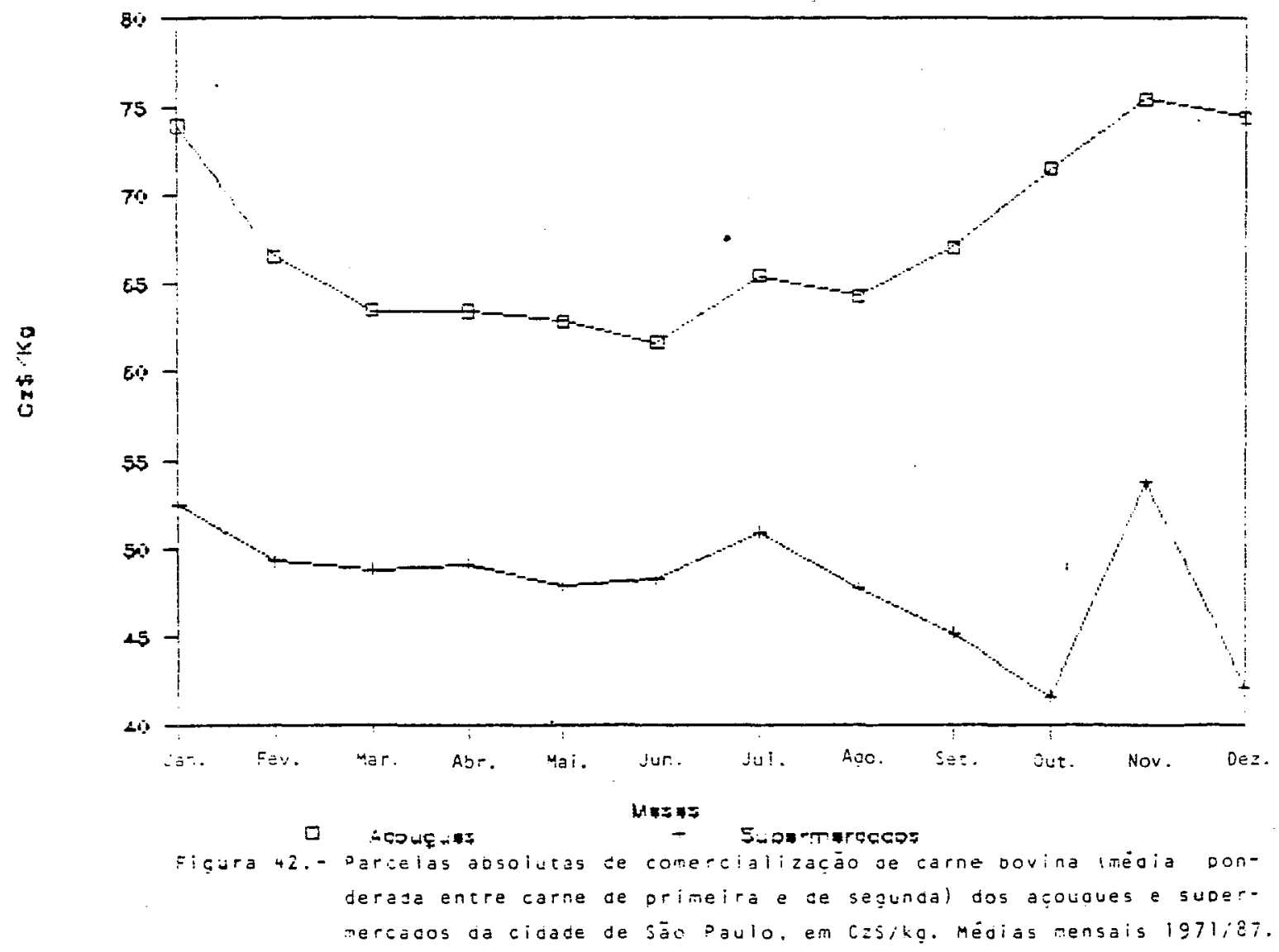




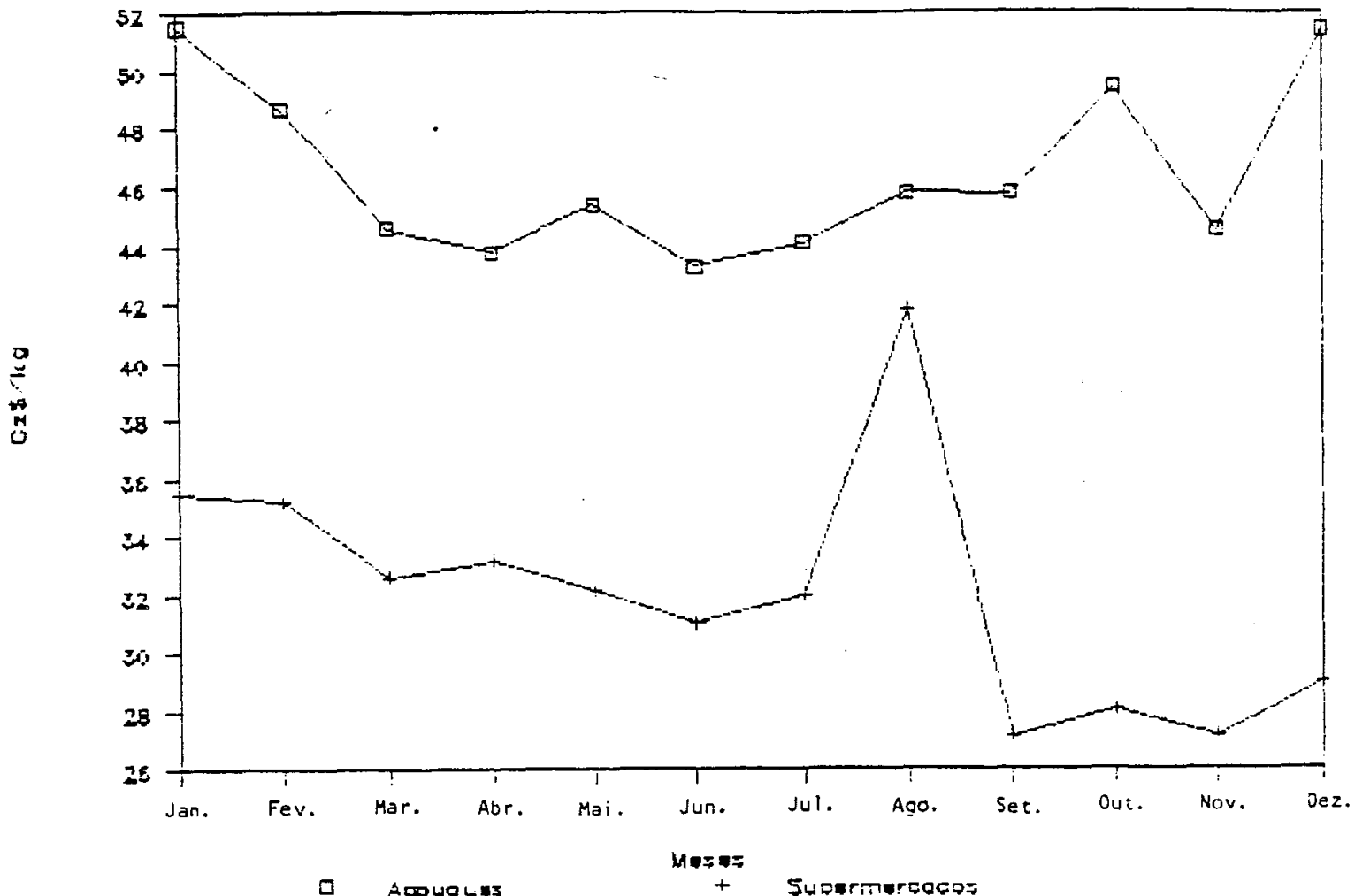

figura 43. - Parcelas absolutas de comercializaçóo de carne bovira de segunda dos açougues e sudermercados da cidade de säo paulo, er. Czs/ha.

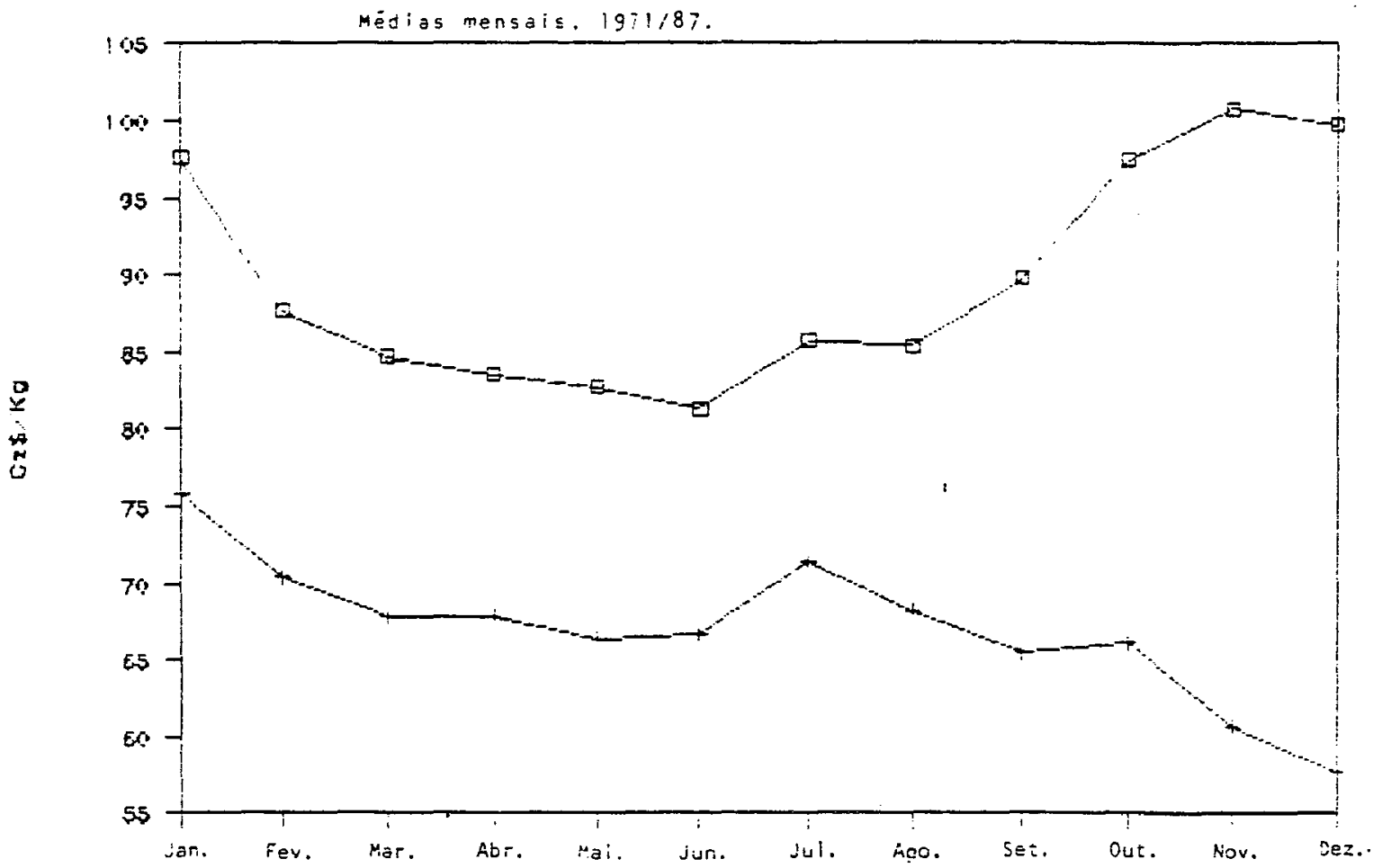

0 hoougtis Husto

Figura 44.- Parcelas assolutas de comercializaça de earne bovina de orineira dos acougues e sudermercados da cidaos de säo faulo, er czs!ks. Mejdias mensais, $1971 / 87$. 


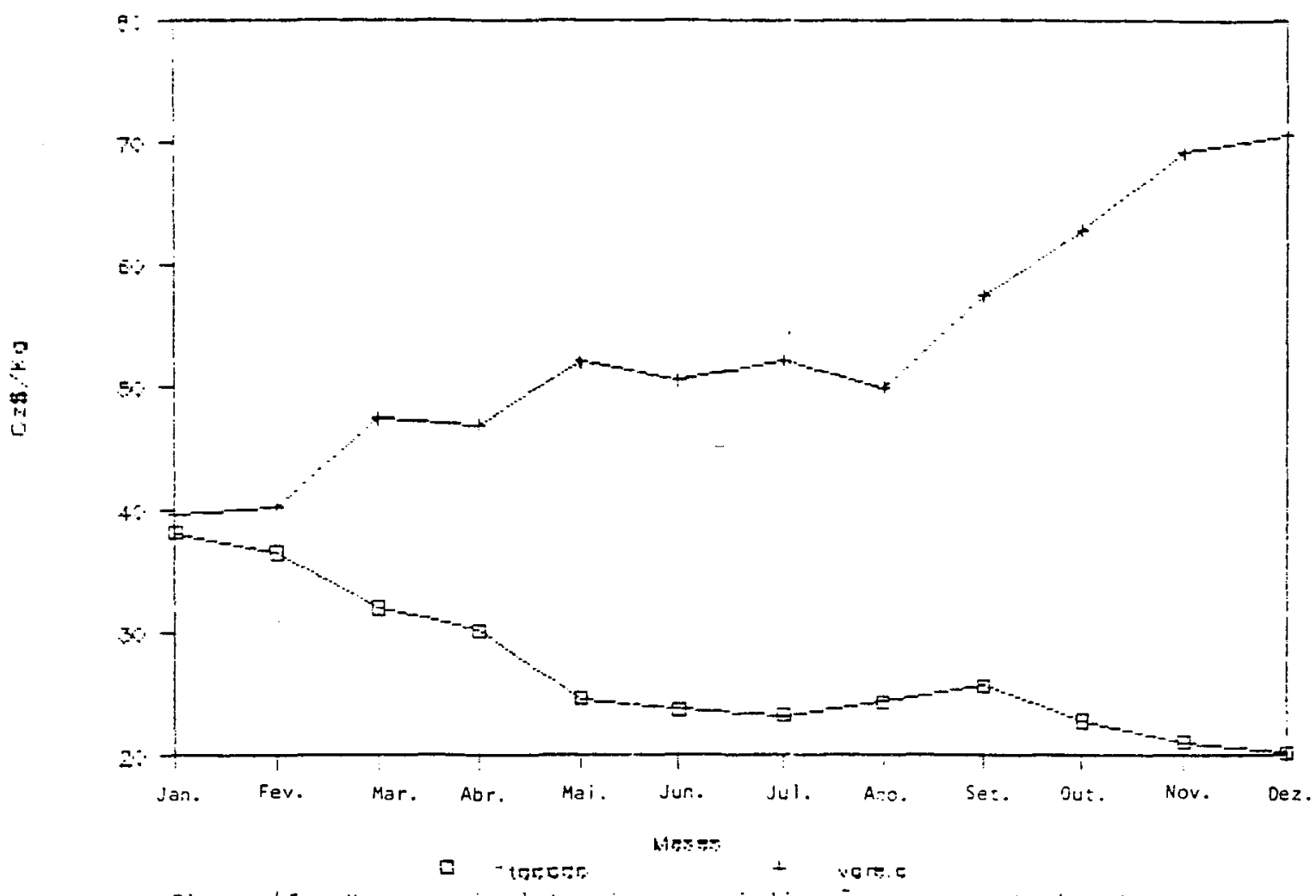

Figura 45.- Margens absolutas je comercializaça a carne bovina do atacado e varejo, em $c z s / k g, \vdots 71$

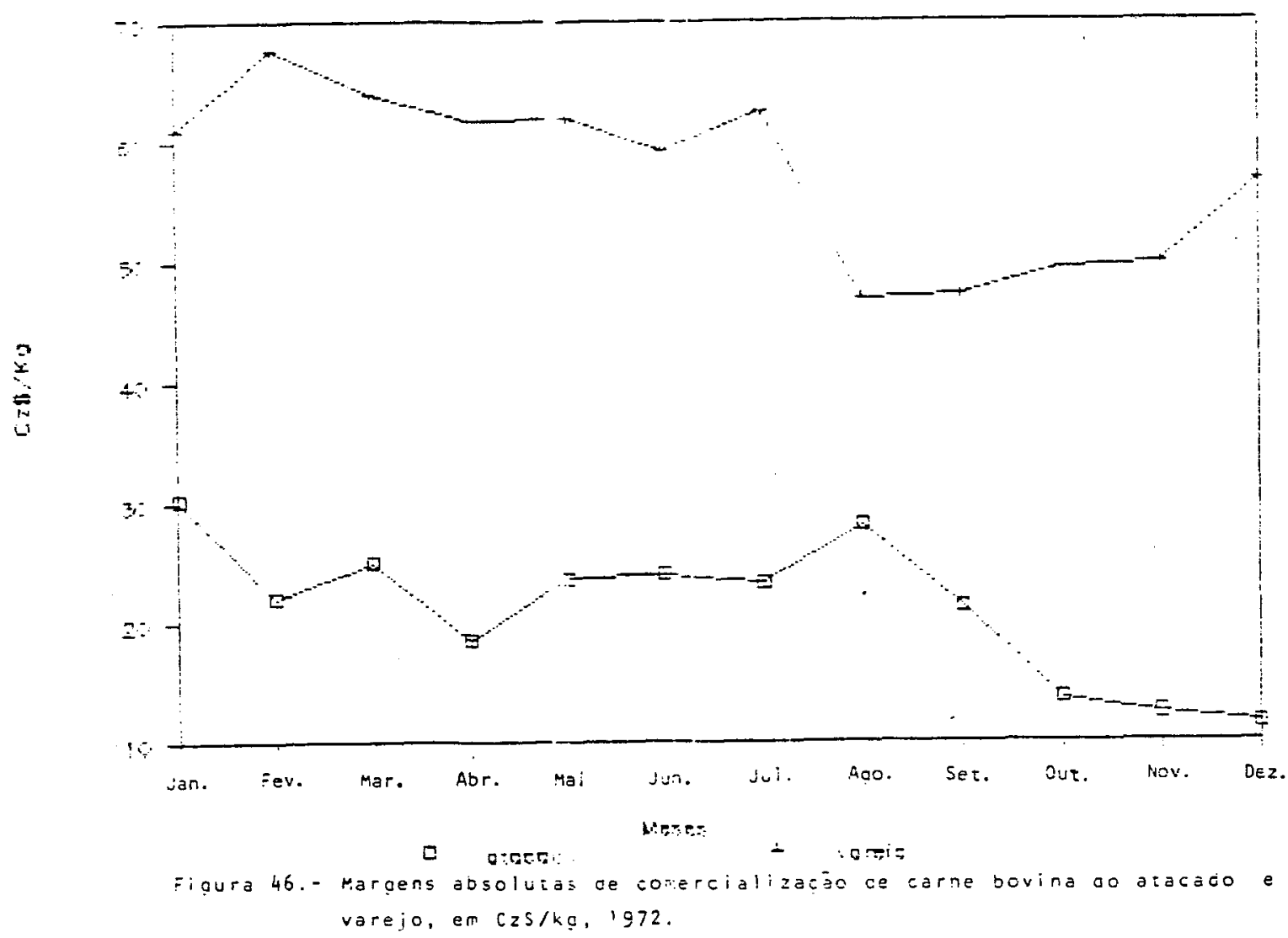




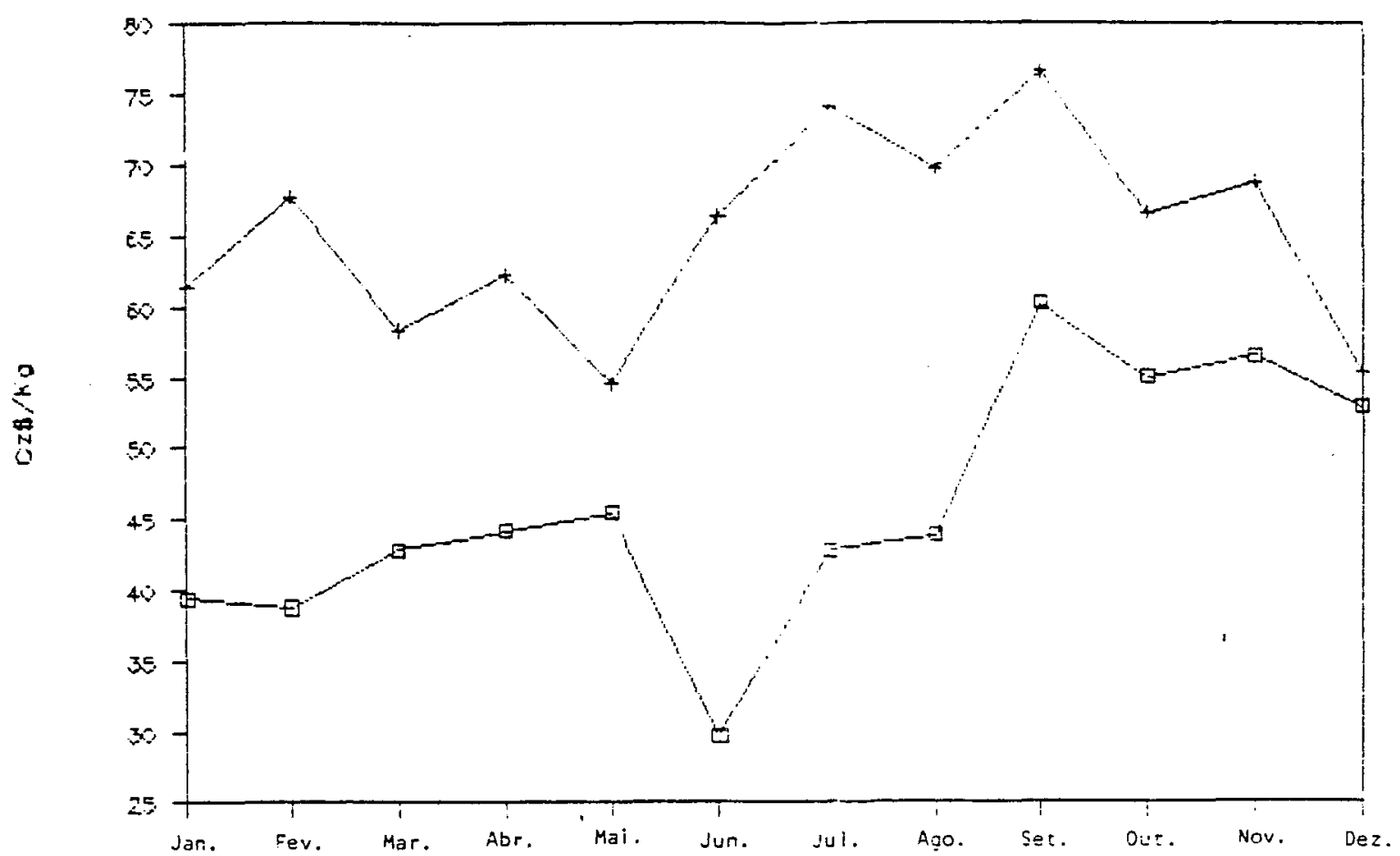

$49-5$

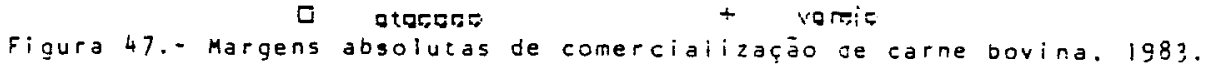

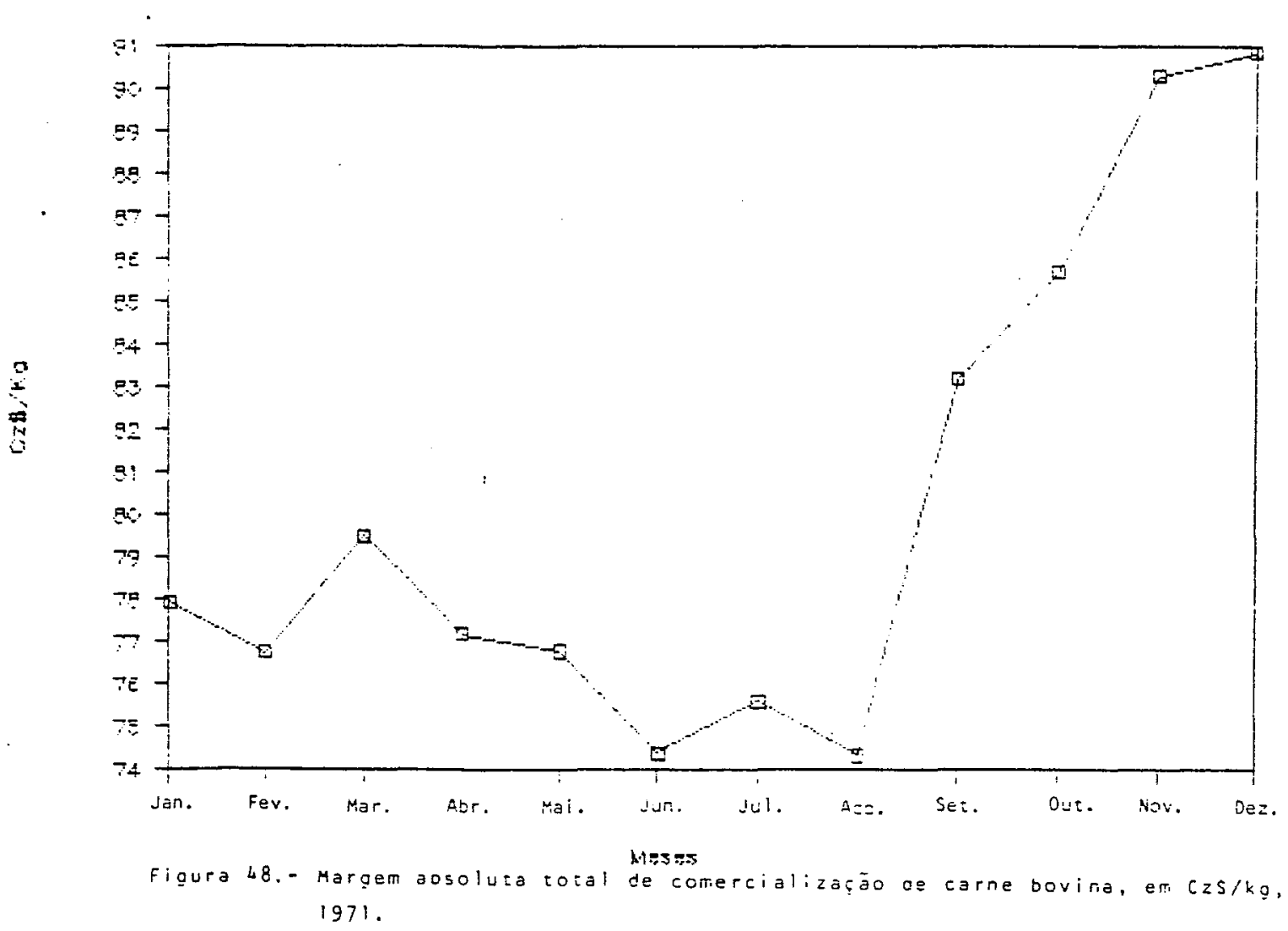


207.

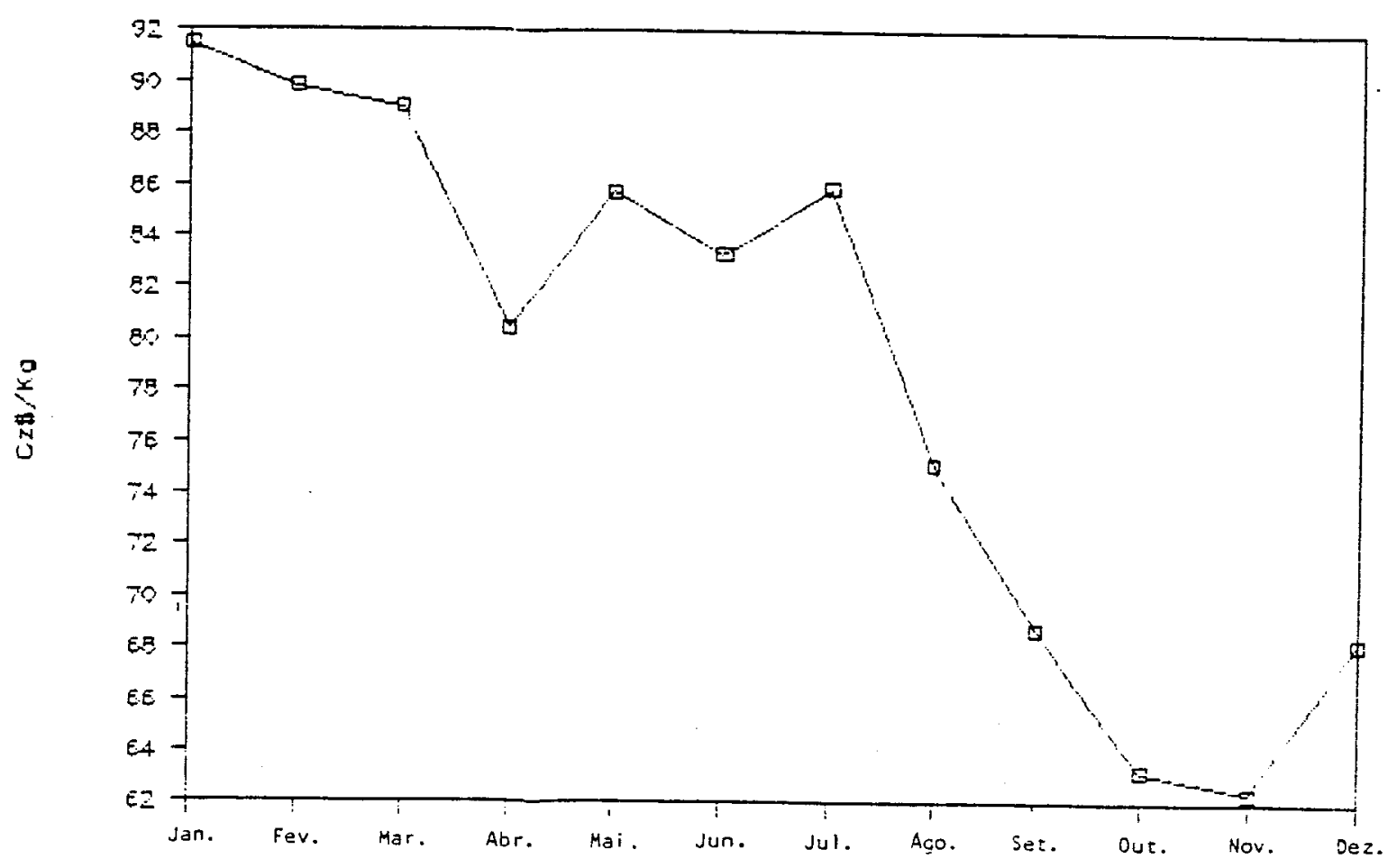

Figura 49.- Marjem absoluta total de comercializaçào de carne bovina, em Czs/kg,
lg72. 1972 .

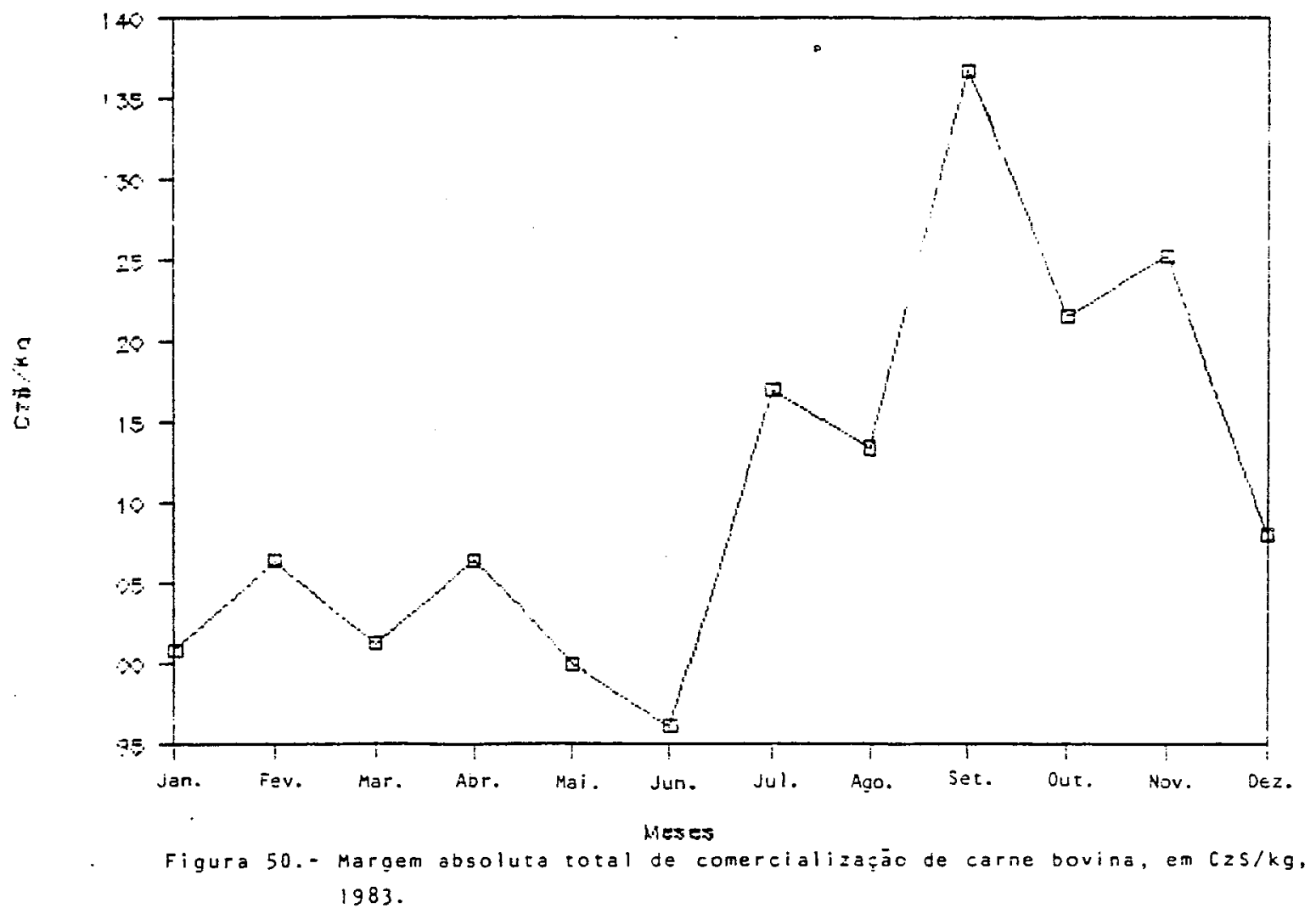



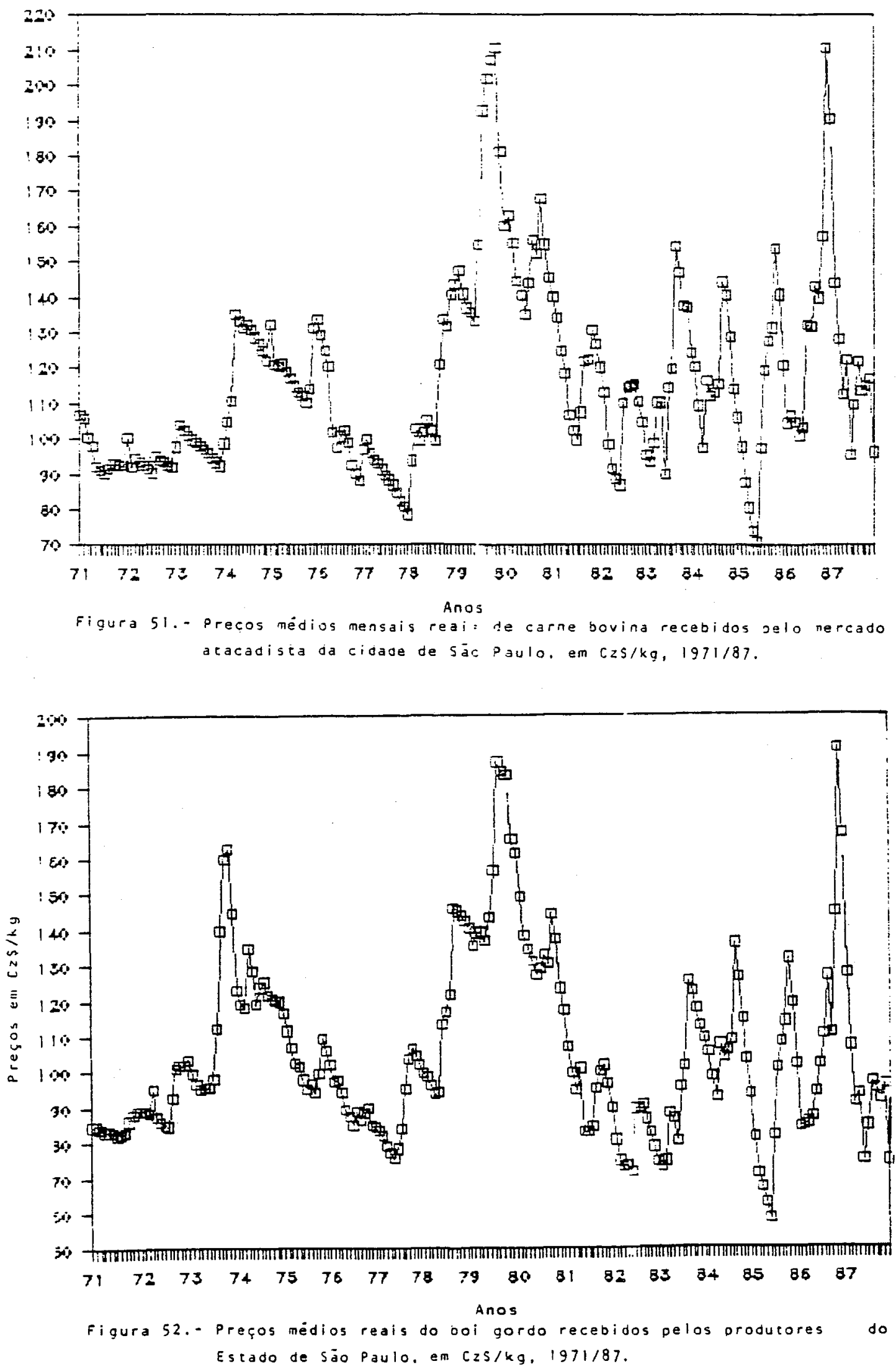


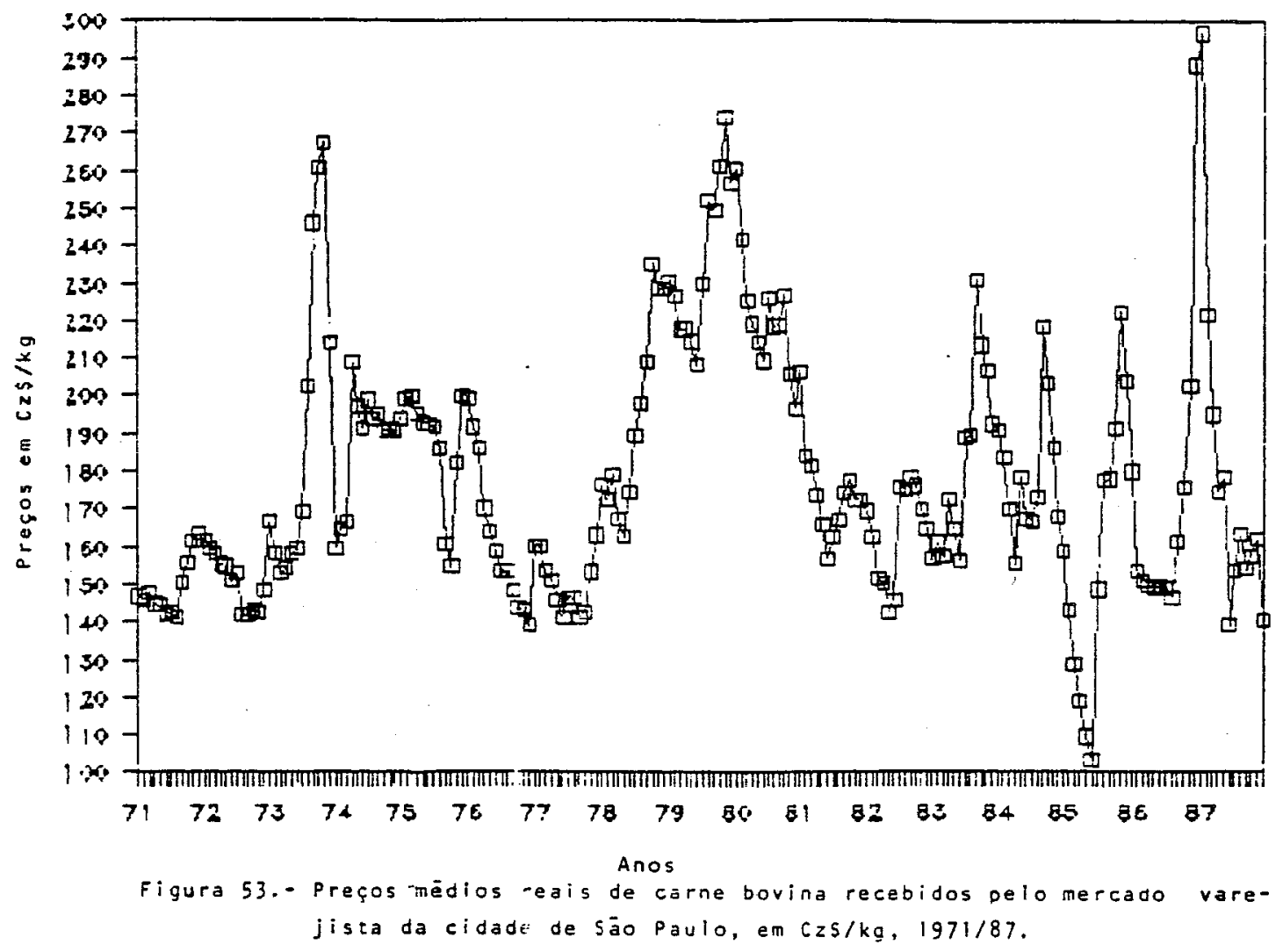

